\title{
A IMPORTÂNCIA DA CONSENSUALIDADE NA IMPLEMENTAÇÃO DA LOGÍSTICA REVERSA
}

\author{
Dissertação apresentada a Banca \\ Examinadora do Programa de Pós-Graduação \\ em Direito, da Faculdade de Direito da \\ Universidade de São Paulo, como exigência \\ parcial para obtenção do título de Mestre em \\ Direito, na área de concentração de Direito do \\ Estado, sob a orientação do Prof. Titular \\ Floriano de Azevedo Marques Neto.
}

UNIVERSIDADE DE SÃO PAULO

FACULDADE DE DIREITO

SÃO PAULO 


\section{TERMO DE APROVAÇÃO}

JULIANE ERTHAL DE CARVALHO

\section{A IMPORTÂNCIA DA CONSENSUALIDADE NA IMPLEMENTAÇÃO DA LOGÍSTICA REVERSA}

Dissertação apresentada como requisito parcial para a obtenção do grau de Mestre em Direito, no Programa de Pós-Graduação em Direito, da Faculdade de Direito da Universidade de São Paulo, na área de concentração de Direito do Estado, pela seguinte Banca Examinadora:

Aprovada em:

Orientador: $\quad$ Professor Titular Floriano de Azevedo Marques Neto

Instituição: $\quad$ Universidade de São Paulo - FADUSP

Julgamento:

\section{Membros:}

Professor(a) Doutor(a):

Instituição:

Julgamento:

Professor(a) Doutor(a):

Instituição:

Julgamento: 


\section{SUMÁRIO}

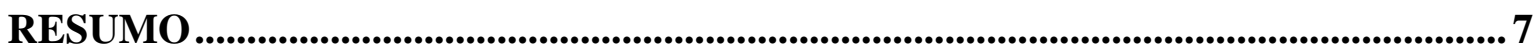

ABSTRACT ....................................................................................................................

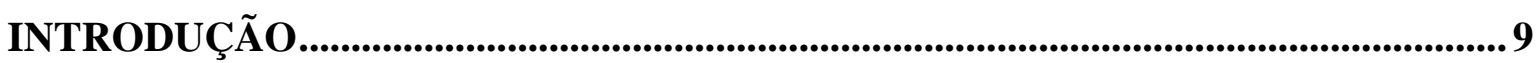

CAPÍTULO 1 - PANORAMA GERAL SOBRE O PAPEL DO ESTADO FRENTE

AOS CIDADÃOS ....................................................................................................12

1.1 Modificações no modo de atuação estatal: a construção novos paradigmas .................12

1.1.1 A ruptura da lógica autoritária de gerenciamento do Estado .................................... 15

1.2 O processo de transição da atuação administrativa unilateral para uma atuação

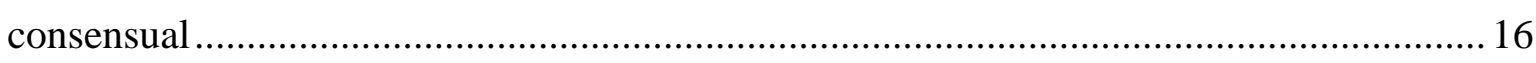

1.2.1 O delineamento das atuações pública e privada .......................................................20

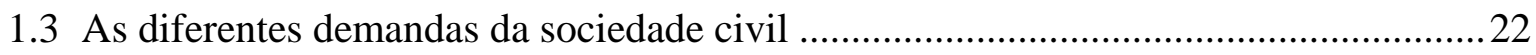

1.3.1 A existência de uma multiplicidade de interesses .....................................................23

1.3.2 Impossibilidade de enclausuramento de interesses sob a clássica fórmula do

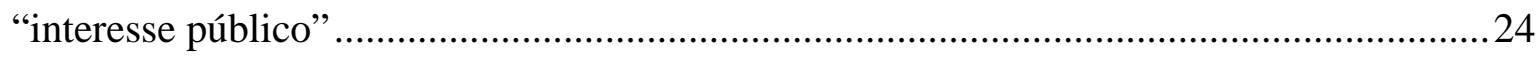

1.4 A questão da compatibilização de interesses presentes na sociedade civil ..................27

1.5 A adoção do método consensual na relação entre Administração Pública e

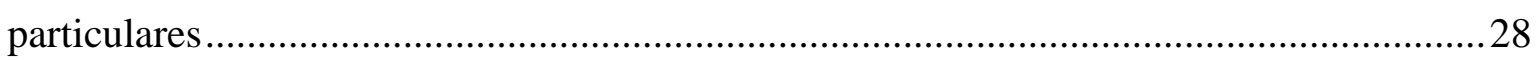

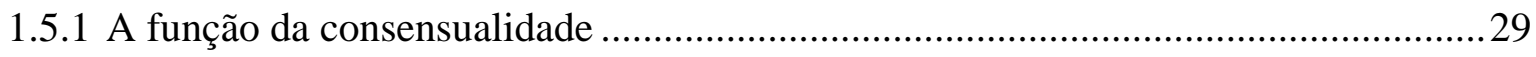

1.5.2 Ausência de redução do poder estatal ......................................................................... 31

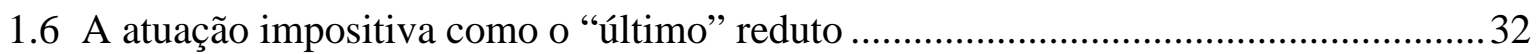

1.7 Mecanismos de consenso existentes no direito brasileiro: a logística reversa ..............34

CAPÍTULO 2 - GESTÃO AMBIENTAL SUSTENTÁVEL E DESENVOLVIMENTO SOCIOECONÔMICO ........................................................... 37

2.1 Direito fundamental ao meio ambiente equilibrado e ao desenvolvimento sustentável 37

2.1.1 A compatibilização dos interesses ambientais e socioeconômicos ............................39

2.1.2 A necessidade de reformulação do modelo econômico ........................................... 41

2.1.3 O problema da definição de desenvolvimento sustentável ..................................... 42

2.2 A gestão de resíduos sólidos como objeto das pautas políticas....................................44

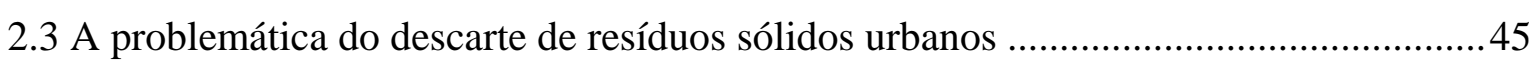

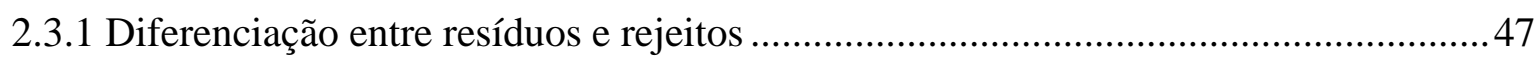

2.4 Diretrizes e regulamentações em matéria de resíduos: o contexto europeu e norteamericano 


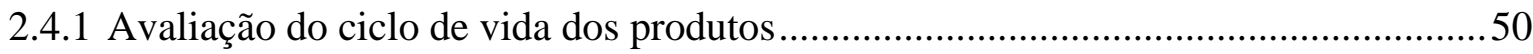

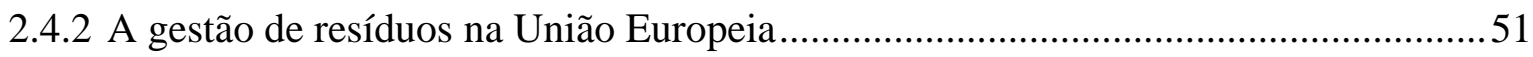

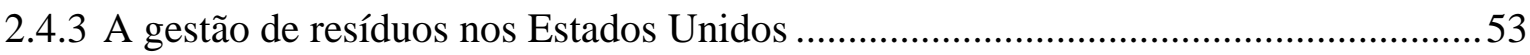

2.5 A prevenção de resíduos sólidos...................................................................................... 55

2.6 A Política Nacional de Resíduos Sólidos: o contexto brasileiro ..................................57

2.7 A regulação estatal como mecanismo de intervenção no domínio econômico e de

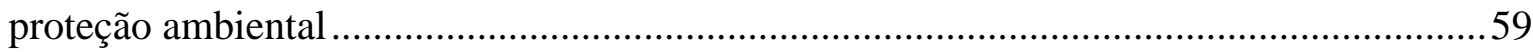

2.8 A importância da participação social na formulação de normas ambientais .................62

2.9 Incentivos normativos a uma atuação sustentável: a gestão de resíduos sólidos .........63

CAPÍTULO 3 - DA IMPLEMENTAÇÃO DA POLÍTICA NACIONAL DE RESÍDUOS SÓLIDOS URBANOS: A LOGÍSTICA REVERSA E A CONSENSUALIDADE ........................................................................................66

3.1 A operacionalização da gestão dos resíduos via logística reversa .................................66

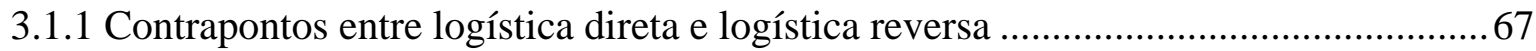

3.1.2 Delimitação conceitual tradicional da logística reversa: ressalva prévia ...................69

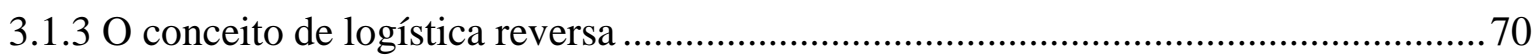

3.1.3.1 Algumas reflexões sobre a concepção tradicional de logística reversa .................... 71

3.2 A caracterização da logística reversa pelo momento do descarte.................................. 73

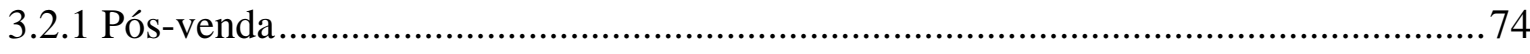

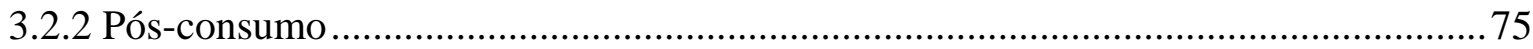

3.3 A diferenciação entre logística reversa e o gerenciamento de resíduos sólidos .............75

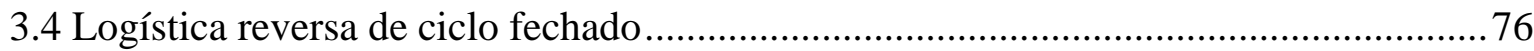

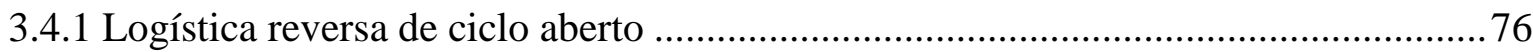

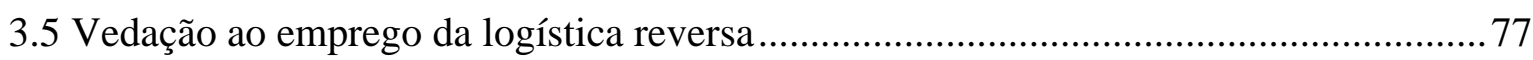

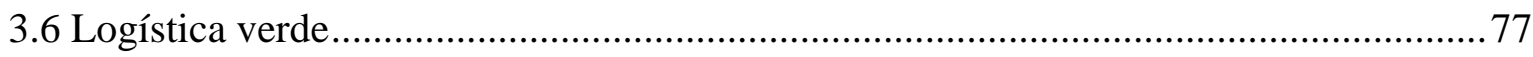

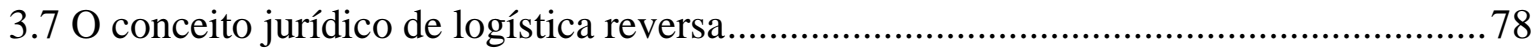

3.7.1 A restituição dos resíduos sólidos ao setor empresarial e o seu reaproveitamento no

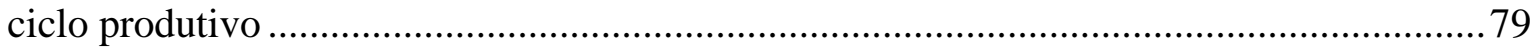

3.7.2 A logística como instrumento de desenvolvimento econômico e social ......................80

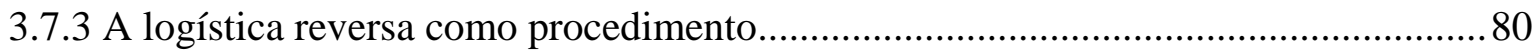

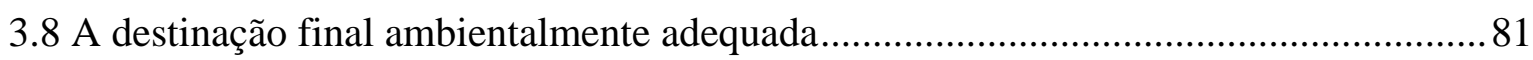

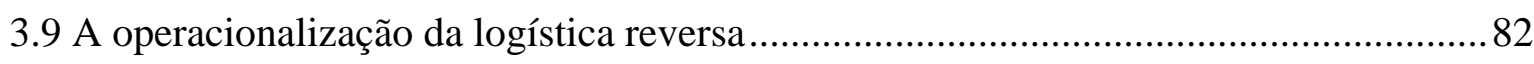

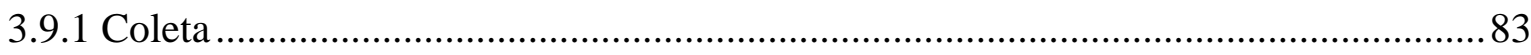


3.9.2 Triagem

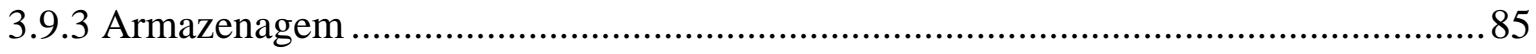

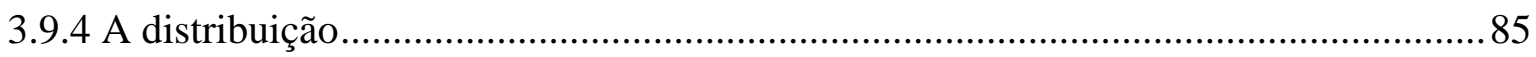

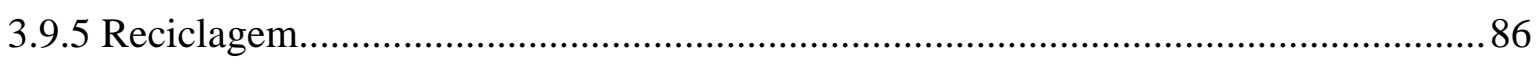

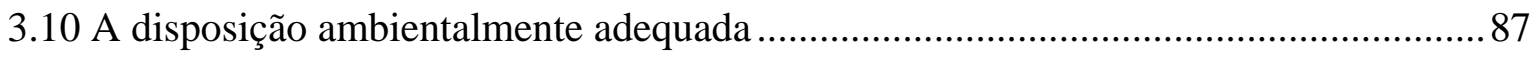

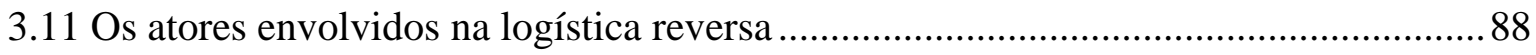

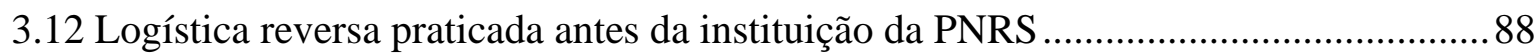

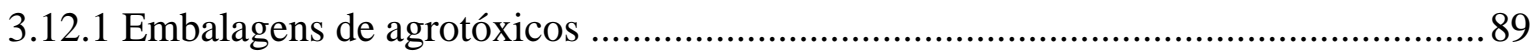

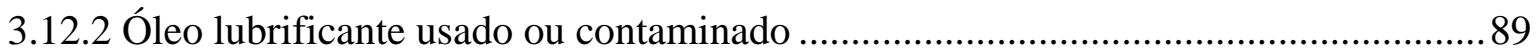

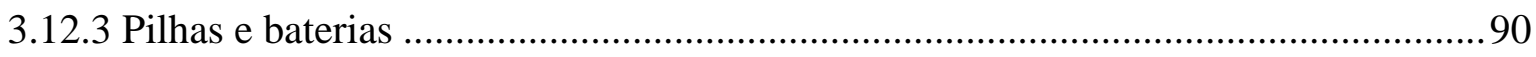

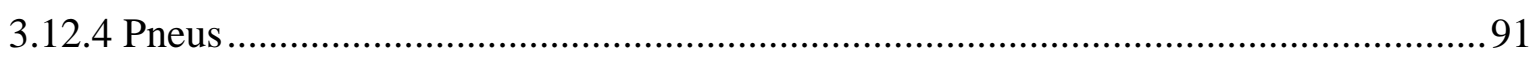

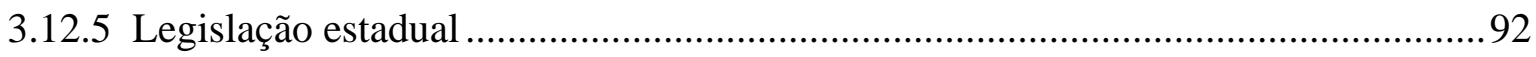

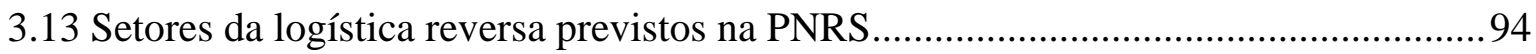

3.13.1 Exemplos de plano estadual e municipal de logística reversa: o setor de

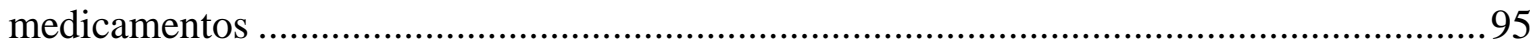

3.14 Comitê Orientador para implementação de Sistemas de Logística Reversa - CORI ..97

$3.15 \mathrm{O}$ impacto regulatório no meio ambiente econômico ..................................................97

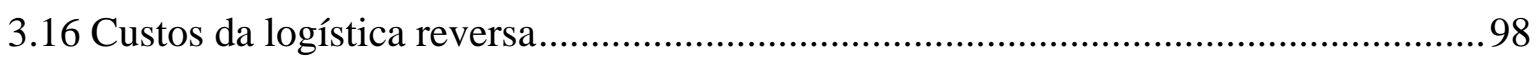

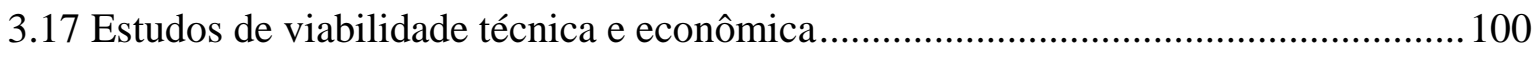

3.18 Os instrumentos de efetivação da logística reversa .................................................100

3.18.1 Acordos setoriais e a relação com a consensualidade............................................100

3.18.1.1 Acordo setorial de embalagens plásticas para armazenamento de óleo

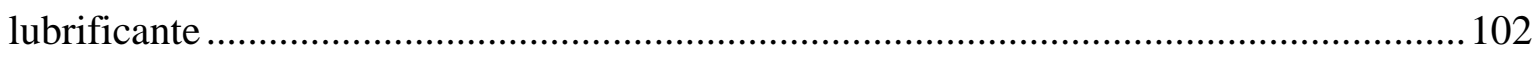

3.18.1.2 Acordo setorial para a logística reversa de lâmpadas fluorescentes .....................103

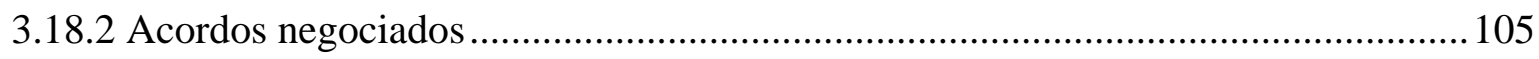

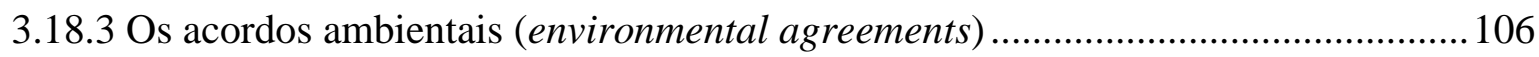

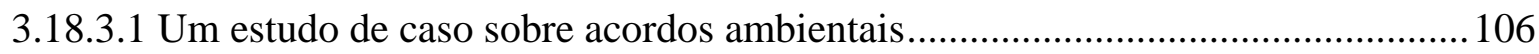

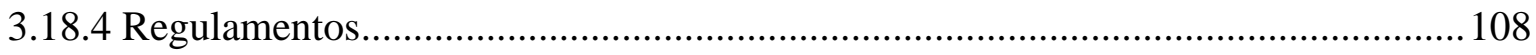

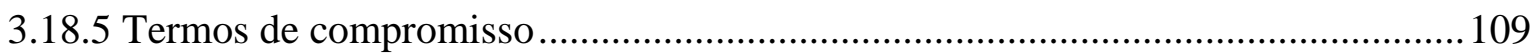

CAPÍTULO 4 - NOÇÕES SOBRE UMA GESTÃO COORDENADA DE

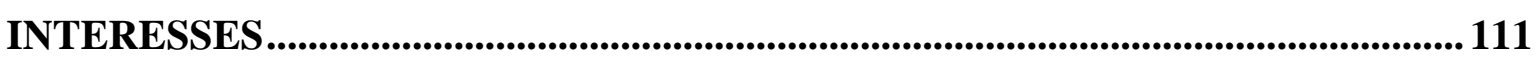

4.1 Redução da atuação impositiva da Administração ................................................... 111

4.1.1 Incentivos práticos às formas dialógicas de relação.................................................112 


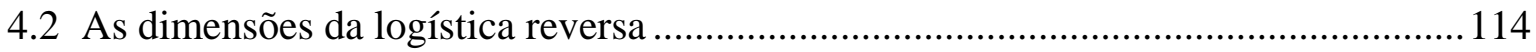

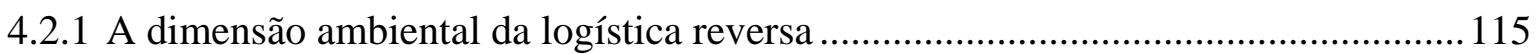

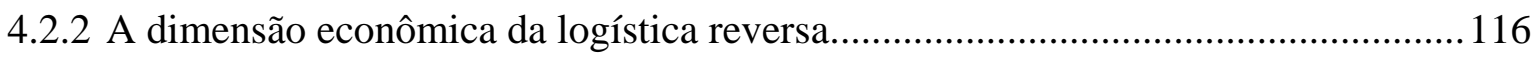

4.2.2.1 Dever jurídico de gestão do ciclo de vida dos produtos: "responsabilidade

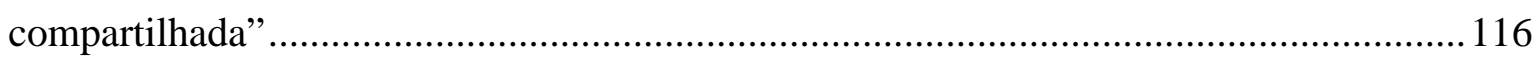

4.2.2.2 O entendimento do STJ acerca da responsabilização pela gestão de resíduos ....119

4.2.2.3 Responsabilidade Alargada do Produtor - Extended Producer Responsability...120

4.2.3 Limites à imposição de deveres para cumprimento da logística reversa ..................122

4.2.3.1 Limitações impostas pelo Poder Judiciário: análise da Ação Civil Pública

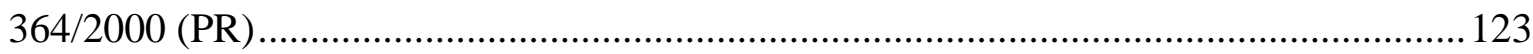

4.3 Compatibilização das dimensões ambiental e econômica ...........................................127

4.4 Estímulos para o aumento da inserção dos resíduos na cadeia econômica .................130

4.5 Criação de novos produtos: a “destruição criativa”....................................................131

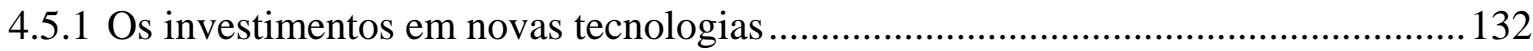

4.5.2 Os custos para implementação de novas tecnologias: o caso das externalidades ....134 4.6 Oportunidades de novos negócios empresariais: economia de serviços e serviços

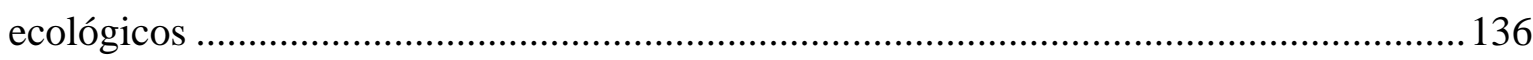

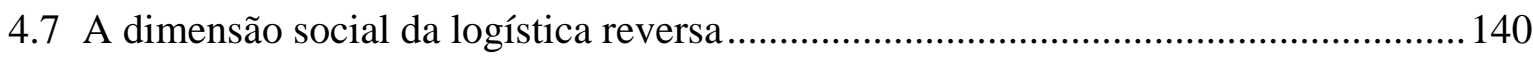

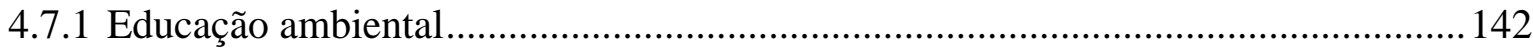

4.8 Razoabilidade da solução de coordenação de interesses ............................................ 143

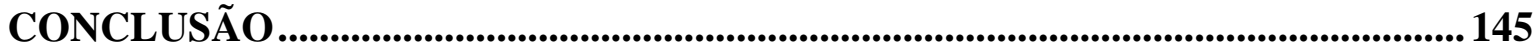

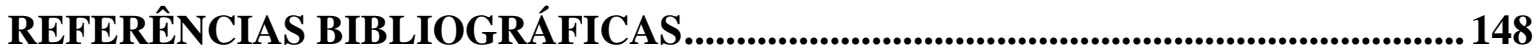


ERTHAL DE CARVALHO, Juliane. 2015. 165 f. A importância da consensualidade na implementação da logística reversa. Mestrado - Faculdade de Direito, Universidade de São Paulo, São Paulo, 2015.

\section{RESUMO}

Partindo-se do pressuposto de que a análise do aspecto socioeconômico não pode ser descolada do prisma ambiental e considerando que as ações de uma esfera impactam sobre a outra, a presente dissertação tem por objetivo investigar (i) o papel assumido pelo Estado e pelos agentes econômicos na implementação da gestão de resíduos sólidos e (ii) em que medida os cidadãos podem participar e colaborar com esse processo. No primeiro capítulo, analisa-se a reformulação do modelo de organização estatal, que passou a se retirar do âmbito de prestação direta de certas atividades para, a partir de então, atuar na regulação e normatização do setor econômico. Esse processo de modificação exigiu uma forma de interação consensual do Estado com a sociedade civil, em que a participação social tende a impor maior rigor de observância dos diversos interesses coletivos na formulação das políticas públicas e das decisões administrativas. No segundo capítulo, pretende-se analisar que a dicotomia entre o aspecto ambiental e o desenvolvimento socioeconômico já não encontra mais sustentação, buscando demonstrar-se que ambas as esferas devem coexistir. Para isso irá se perpassar por discussões relativas à sustentabilidade e à atuação normativa e regulatória do poder público em relação à gestão de resíduos sólidos. No terceiro capítulo, irá procurar se delimitar aspectos da logística reversa desde conceitos, abrangência até formas de efetivação, elencando-se também alguns aspectos normativos e práticos. No último capítulo, irá se avaliar como a redução da atuação impositiva do Estado é relevante para a implementação do instrumento da logística reversa e como pode haver uma gestão coordenada de interesses estatais, dos agentes econômicos e cidadãos. Desse modo, objetiva-se recorrer ao instrumento da logística reversa para se aprofundar a reflexão sobre a importância do método consensual de elaboração das decisões administrativas.

Palavras-chave: Política Nacional de Resíduos Sólidos, Lei 12.305/2010, sustentabilidade, logística reversa, consensualidade. 
ERTHAL DE CARVALHO, Juliane. 2015. 165 p. The importance of consensuality in implementation of reverse logistics. Master - Faculty of Law, University of São Paulo, São Paulo, 2015.

\begin{abstract}
Starting from the assumption that the analysis of the socio-economic aspects can not be separated from the environmental perspective, since the actions of one sphere have an impact on the other, this thesis aims to investigate (i) the role of the State and the economic agents in the implementation of solid waste management and (ii) the extent of how much the citizens can participate and contribute to this process. The first chapter analyzes the reformulation of the state organization model, which change from the scope of direct provision of certain activities to the act in the regulation and standardization of the economic sector. This modification process required a form of consensual interaction of the State with civil society, in which social participation tends to impose stricter observance of the many collective interests in the formulation of public policies and administrative decisions. The second chapter intend to analyze the dichotomy between the environmental aspect and the socio-economic development that no longer find support, and for that, seek to demonstrate that both spheres must coexist. For this reason, it is necessary to enter in the discussions on sustainability and normative and regulatory role of the government in relation to solid waste management. The third chapter search for the definition of some aspects of the reverse logistics, as concepts, scope and forms of execution, describing some normative and practical aspects. The last chapter will assess how the reduction of imposing role of the State is relevant to the implementation of reverse logistics tool and how can there be a coordinated management of state interests, economic agents and citizens. Thus, the objective of this work is to use the reverse logistics tool to further reflect on the importance of consensual method of the preparation of administrative decisions.
\end{abstract}

Keywords: National Solid Waste Policy, Law 12.305/2010, sustainability, reverse logistics, consensuality. 


\section{INTRODUÇÃO}

O gerenciamento de recursos naturais e a proteção do meio ambiente durante muito tempo ficaram vinculados ao padrão de desenvolvimento econômico. Com isso houve a "predação" dos recursos, visto que não se adotavam medidas de proteção ambiental para compensar o uso desmedido ${ }^{1}$. Não havia preocupação com o planejamento das ações, considerando-se os efeitos futuros. Contudo, os recursos naturais são essenciais para o desenvolvimento socioeconômico, sem eles não há matéria-prima e nem condições de existência humana. Logo, não há como se desenvolver seja econômica ou socialmente sem a utilização racional dos recursos. A vida humana não se desenvolve de modo isolado, ou seja, não pode ser destacada do meio ambiente, portanto qualquer forma de desenvolvimento socioeconômico necessita ser sustentável.

O desenvolvimento sustentável não envolve apenas a proteção ao meio ambiente, mas também a proteção à qualidade de vida, relações sociais mais justas e distributivas e um desenvolvimento econômico que seja capaz de manter-se ao longo do tempo, produzindo riquezas e o bem-estar social sem comprometer o funcionamento do ecossistema. O desenvolvimento sustentável pode ser compreendido como uma nova forma de pensar a organização social, a vida política, um crescimento econômico que estejam em harmonia com a natureza e possibilitem maior justiça social.

Nesse contexto e considerando a atual escassez de recursos, a gestão adequada dos resíduos sólidos é tema que tem ganhado evidencia nas pautas políticas, econômicas e sociais. Muitos resíduos ainda não recebem o devido tratamento, sendo indevidamente desperdiçados. Tal situação tem gerado o acúmulo de forma desorganizada desses resíduos, além da contaminação dos solos, das águas e a proliferação de doenças.

Uma gestão adequada de resíduos é dependente de um conjunto de medidas, que envolve não apenas o tratamento e a disposição ambientalmente adequados, mas também a alteração de padrões produtivos, o que envolve repensar-se novas formas de design e durabilidade de produtos, novos padrões de consumo, novas estratégias de marketing, formas de redução da utilização de matérias-primas e de recursos não renováveis e o aumento da eficiência energética.

\footnotetext{
${ }^{1}$ MOREIRA NETO, Diogo de Figueiredo. Introdução ao Direito Ecológico e ao Direito Urbanístico, 1975, p. 18.
} 
Para viabilizar a gestão adequada de resíduos o setor produtivo se vale da adoção de alguns instrumentos como a logística reversa, que visa a operacionalizar e planejar o reaproveitamento dos resíduos, mediante tratamento prévio ou não, no ciclo produtivo em que se originou ou em algum outro em que seja compatível. Esse processo relaciona-se ao fechamento do ciclo produtivo, mediante a valorização de resíduos que seriam abandonados, ou eliminados, por meio de aterragem, compostagem ou incineração. Desse modo, a logística reversa possibilita a instituição de um modo alternativo de obtenção de matéria-prima, que se dá mediante essa valorização de resíduos.

Além do fechamento do ciclo produtivo, a logística reversa reduz a destinação de materiais que podem ser úteis para a produção para a aterragem, compostagem e incineração porque a transformação do resíduo em matéria-prima secundária a possibilita a sua reinserção na cadeia produtiva.

A operacionalização adequada da logística reversa pode gerar um custo-benefício para as empresas, visto que possibilita auferirem ganhos econômicos com a redução da necessidade de obtenção de matérias-primas do meio ambiente e com a redução dos custos com a obrigação de disposição final de resíduos, que passam então a ser reaproveitados ou reutilizados ${ }^{2}$.

A logística reversa também permite redução dos custos sociais e de custos relacionados à imagem das empresas, que são decorrentes da disposição inadequada de resíduos e da consequente degradação do meio ambiente, além de reduzir espaços físicos que seriam utilizados para a construção de locais onde os resíduos que não possam ser reaproveitados, denominados nesse caso de rejeitos, necessitariam ser dispostos.

Mas para que seja efetiva e eficaz, a logística reversa depende do desenvolvimento de tecnologias que permitam a superação das fórmulas de gestão de resíduos e de desenvolvimento econômico. A modificação dos componentes dos produtos, dos materiais utilizados na fabricação, do tempo de durabilidade, assim como a criação de designs que permitam maior facilidade de reuso e reciclagem, possibilitam que seja potencializada a eficácia da logística reversa.

\footnotetext{
${ }^{2}$ A disposição final dos produtos descartados, em grande medida, costumava ser uma obrigação imposta apenas ao Poder Público, que efetuava a coleta e o encaminhamento aos aterros, lixões e/ou usinas de incineração. No entanto e considerando o aumento vertiginoso de resíduos e rejeitos, em diversos países, como aqueles que integram a União Europeia, Estados Unidos, Canadá, Brasil, Japão, dentre outros, passouse a impor essa obrigação também ao setor econômico. Há um compartilhamento dos custos sociais decorrentes do descarte de resíduos entre todos os agentes da cadeia produtiva, que sejam responsáveis, direta ou indiretamente, pela produção de resíduos.
} 
A educação ambiental também é um importante pilar para o desenvolvimento da logística reversa, porque permite a tomada de consciência da sociedade civil em relação aos problemas ambientais. Além, claro, de estimular novos padrões de comportamento que sejam mais adequados ao desenvolvimento sustentável.

A legislação brasileira, desde a década de oitenta, tem adotado medidas para implantação da logística reversa, mas consolidação em um diploma de abrangência nacional deu-se apenas em 2010, por meio da edição da Lei 12.305/2010, que institui a Política Nacional de Resíduos Sólidos - PNRS. A modelagem proposta para a implementação da logística reversa leva em conta os seguintes aspectos: a fonte de recurso para a viabilização e a imposição de deveres tanto ao Poder Público, como ao setor empresarial e aos cidadãos.

Dentre outros aspectos, o Estado assume a obrigação de fiscalizar a implementação das políticas públicas definidas legislativamente e das diretrizes regulatórias em matéria de gestão de resíduos e proteção ambiental; o setor econômico atua na compatibilização dos métodos produtivos com a preservação do meio ambiente e com a redução da geração de resíduos e os cidadãos devem atuar adequada e conscientemente tanto no consumo como no descarte de resíduos.

A logística reversa é instituída, portanto, por meio do compartilhamento de deveres jurídicos entre o Estado e a sociedade civil, isso, em grande medida, porque a gestão de resíduos sólidos envolve a todos e se caracteriza como uma tarefa bastante complexa, que demanda a cooperação de diversos setores para a sua efetivação. Isso exige uma nova concepção de atuação pública, pauta na consensualidade. Ou seja, uma concepção em que a Administração não mais atuará de forma impositiva, mas em cooperação com a sociedade civil, formulando decisões e políticas públicas que considerem em sua formulação todos os múltiplos interesses que possam estar envolvidos.

Adiante serão esboçadas algumas questões relativas à compatibilização dos interesses sociais, econômicos e ambientais em matéria ambiental e do papel do Estado na formulação de normas e políticas públicas para a gestão de resíduos sólidos, o que conduzirá inclusive a uma reflexão acerca da necessidade de uma nova postura estatal, mais consensual, para com a sociedade. 


\title{
CAPÍTULO 1 - PANORAMA GERAL SOBRE O PAPEL DO ESTADO FRENTE AOS CIDADÃOS
}

\subsection{Modificações no modo de atuação estatal: a construção novos paradigmas}

As relações entre o Estado e a sociedade civil envolvem um contínuo e dinâmico processo de adaptação e reformulação, que é moldado pelo contexto histórico em que se inserem ${ }^{3}$.

As modificações do papel do Estado na modulação da atividade econômica e a própria interação que ele assume para com os cidadãos estão associadas, em grande medida, à ineficiência de sua atuação que acaba por dificultar, reduzir ou inviabilizar a satisfação dos interesses individuais e coletivos. Essa ineficiência também se torna um entrave a um desenvolvimento econômico satisfatório.

Esse contexto impõe a busca de renovação do modelo estatal, econômico e da forma de participação social na tomada de decisões políticas e econômicas. A busca por novos métodos e novas formas de superação dos problemas impõe uma transição de paradigma. Como destaca DIOGO DE FIGUEIREDO MOREIRA NETO, com escólio nas teorizações de THOMAS KUHN:

\begin{abstract}
“(...) quando os problemas que inevitavelmente se vão apresentando já não admitem solução pelo emprego dos paradigmas vigentes, a comunidade científica é movida pela necessidade de superar essa crise de efetividade, pesquisando $e$ formulando novos paradigmas, que serão, a princípio, postos em dúvida e sob contestação, experimentação e debate, até que se imponham por suas qualidades, substituindo os anteriores $e$ completando o ciclo de renovação ${ }^{4, "}$ (grifou-se).
\end{abstract}

As alterações da estrutura e das funções assumidas pelo Estado são um processo contínuo e inerente à própria dinâmica das relações sociais que o delimitam. Com isso o papel do Estado não perde em importância, mas ele se modifica, não necessariamente

\footnotetext{
${ }^{3}$ Alguns autores aludem a essa característica de constante mutabilidade como um estado de crise permanente das instituições e estruturações estatais. Nesse sentido, confira-se: “(...) o Estado pós-moderno é um Estado em crise permanente. Não apresenta uma face estável e se encontra em contínua modificação. As propostas de alteração nem são implementadas e já estão sendo substituídas por outras. O mesmo se passa com o próprio direito”. (JUSTEN FILHO, Marçal. Curso de Direito Administrativo. 10. ed., 2014, p. 106).

${ }^{4}$ Poder, Direito e Estado. O Direito Administrativo em tempos de globalização, 2011, p. 68.
} 
evolui, mas ele muda o seu modo de organização e atuação para obter melhores resultados nas atividades e ações desempenhadas ${ }^{5}$ ”.

Ademais, as próprias necessidades sociais tendem a se modificar ao longo do tempo, caracterizando-se por circunstâncias altamente mutáveis e exigindo sempre novas atuações estatais ${ }^{6}$. As sociedades contemporâneas, de um modo geral, têm vivenciado um processo de modificação muito intenso. As revoluções tecnológicas e do modo de vida impõem uma gama de novas necessidades que geram o aumento exponencial de recursos financeiros, infraestruturas, serviços e atividades para a satisfação da qualidade de vida. Para tanto o Estado pode se valer de diferentes modos de intervenção na economia, seja por meio de atuação de polícia, regulação econômica, fomento, serviço público etc.

O Estado que, até então, era dotado de dimensões consideráveis, no sentido de que possuía uma grande e complexa estrutura para atuação direta na prestação de diversas atividades $^{7}$, vê-se constrangido a reformular sua atuação e consequentemente suas estruturas. Como destaca GASPAR ARIÑO ORTIZ, o Estado “produtor” tem se reduzido ao mínimo, e um reflexo disso são as privatizações de grande parte das participações estatais no setor empresarial, passando atuar como agente regulador e financiador do setor econômico ${ }^{8}$.

A incapacidade seja financeira, técnica, operacional ou administrativa do Estado conduz à redução de sua atuação na intervenção direta no domínio econômico. Nesse sentido destaca ANA ROQUE:

"Como característica essencial do fenômeno regulatório, diga-se que o Estado pode perfeitamente prescindir do seu papel de detentor dos meios de produção, seja como empresário, seja como sócio de outros investidores, sem tal signifique de todo, uma atitude de menosprezo pela vida econômica, ou de impotência face a seu desenrolar; pelo contrário, a regulação abre novas possibilidades à intervenção condicionadora do Estado, incluindo a intervenção indirecta na dimensão regulamentadora ${ }^{9, "}$.

\footnotetext{
${ }^{5}$ Conforme destaca LUIS S. CABRAL DE MONCADA: “Uma concepção do Estado distingue-se das outras consoante o fim perseguido”. Direito Económico. 2. ed., 1988, p. 20.

${ }^{6}$ MONCADA, Luis S. Cabral de. Direito Económico. 2. ed., 1988, p. 31.

${ }^{7}$ Nesse sentido, confira-se: "O papel jurídico do Estado alargou-se a todas as esferas de actividade, com destaque para a economia e a sua atividade assumiu finalidade próprias, distintas das dos indivíduos. A actividade econômica deixou de ser mais um sector indiferenciado da actividade privada geral para passar a ser objecto específico da actividade conformadora dos Poderes Públicos” (MONCADA, Luis S. Cabral. Direito Económico. 2. ed., 1988, p. 23).

8 Principios de Derecho Público Económico. Modelo de Estado, Gestión Pública, Regulación Económica. 3. ed., 2004, p. 336.

${ }^{9}$ Regulação do Mercado. Novas tendências, 2004, p. 10.
} 
O Estado regulador permite condicionar positiva ou negativamente a conduta dos particulares. No primeiro caso, adotam-se incentivos para que se produza determinada ação e no segundo caso, proíbem-se determinadas ações ou até mesmo omissões. O Estado deixa, em grande medida, de concorrer com os agentes econômicos no modelo de atuação regulatória ${ }^{10}$.

Com isso não se pretende sustentar que o Estado deixe de ter centralidade na modulação do setor econômico, mas sim que o foco principal de sua atuação passa a ser uma função orientadora e normativa, até porque ele não abandona por completo a atuação como interventor direto ${ }^{11-12}$. Nesse sentido, ao invés de o ente estatal executar as atividades diretamente ele altera “(...) o comportamento dos agentes econômicos (produtores, distribuidores, consumidores), em relação ao que eles teriam se não houvesse a regulação, isto é, se houvesse apenas as regras do mercado ${ }^{13,}$.

Em síntese, a atuação estatal na prestação direta das atividades mostrou-se ineficiente e, desse modo, o Estado contemporâneo tem deslocado o seu eixo principal de atuação da esfera interventiva para uma esfera regulatória. Essa modificação envolve uma reflexão sobre o papel que tem sido assumido pelo Estado na modulação do domínio econômico e na relação que ele estabelece com os cidadãos.

\footnotetext{
${ }^{10}$ SANTOS, António Carlos dos; GONÇALVES, Maria Eduarda; MARQUES, Maria Manuel Leitão. Direito Económico. 4. ed., 2001, p. 68.

${ }^{11}$ A atuação estatal não perde importância até porque, em períodos pretéritos - Estado Liberal, uma atuação exclusivamente privada no domínio econômico também não se mostrou satisfatória, o que, aliás, conduziu o Estado a alargar suas estruturas e adotar essa posição de interventor direto nas atividades econômicas. Nesse sentido: “(...) até o fim do liberalismo, o Estado não intervinha na ordem econômica, concentrava-se na manutenção criteriosa da ordem social através da proteç̧ão das instituições fundamentais, visível na criação e aplicação de um direito essencialmente negativo, no sentido de se expressar sobretudo através de proibições. (...) Ao Estado e ao direito cabia a abstenção face à pujança das liberdades de iniciativa e de empresa e aos direitos de propriedade privada e de estabelecimento, salvo para os proteger faze a eventuais violações da respectiva integridade" (ROQUE, Ana. Regulação do Mercado. Novas tendências, 2004, p. 33).

${ }^{12}$ Nesse sentido ensina SABINO CASSESE: “(...) a liberalização mesma produz a necessidade de uma forte regulação (...) o Estado assume dimensão mais limitada, isso se expande, por outro lado, com a instituição da autoridade independente, introduzida para desenvolver uma forma autônoma de controle de regulação ou de adjudicação" (tradução livre). (CASSESE, Sabino, Quattro paradossi sui rapporti tra poteri pubblici ed autonomie private, 2000, p. 393). Confira-se ainda ANA ROQUE: "A liberalização do mercado não significa, pois, necessariamente, a sua retirada da influência do Estado, uma vez que pode ser conciliada com amplas e eficazes atitudes interventivas, através da dotação de regras para os sectores de actividade objecto de regulação". (Regulação do Mercado. Novas tendências, 2004, p. 10).

${ }^{13}$ MOREIRA, Vital. Auto-regulação profissional e administração pública, 1997, p. 36.
} 


\subsubsection{A ruptura da lógica autoritária de gerenciamento do Estado}

Outra alteração paradigmática que deve ser destacada é a consolidação de um Estado de Direito e mais especificamente um Estado Democrático de Direito.

A transição para um Estado de Direito insere-se num contexto em que houve a reformulação do modelo estatal para se mitigar a noção autoritária de Estado, na qual o soberano é totalmente livre para praticar quaisquer atos, ações e omissões sem qualquer justificativa ou fundamentação ${ }^{14}$.

Dessa maneira, e considerando a crise de legitimidade do Estado, foram impostos alguns limites ao poder estatal, que, a partir de então, passou a ter de se submeter à ordem jurídica, mais especificamente à legalidade e à separação de poderes. Como destaca CARLOS ARI SUNDFELD: “No período absolutista, Estado-Polícia significava um poder ilimitado, valendo-se do Direito para controlar a sociedade, ordenando e coagindo, sem sujeitar-se a ele. Mas, com a implantação do Estado de Direito, novas bases de assentaram na relação entre autoridade e cidadão ${ }^{15}$ ".

Essa nova ordem jurídica reconheceu a importância de o Estado adotar soluções que possibilitassem a satisfação dos interesses individuais, sem discriminação e arbítrio no exercício da atividade administrativa. Com isso ganha destaque uma estruturação vinculada à ideia de interesses coletivos.

No entanto e como destaca JORGE REIS NOVAIS, essa nova ordem fundada na legalidade e na separação de poderes também se fundamenta em técnicas jurídicas que são legitimadas pelo “império”, que impõe uma “razão legisladora vinculativa para todos” ${ }^{16}$. Com o tempo e diante de uma lógica meramente formal de legalidade, houve um distanciamento entre a proteção dos direitos individuais e a atuação da Administração. Isso porque a lei estabelecia direitos meramente formais, no sentido de que não eram concretizados. Esse autor complementa adiante: “A perspectiva formal do Estado de Direito seria então utilizada para fornecer o álibi jurídico ao autoritarismo ${ }^{17,}$.

Esse contexto conduziu à busca por uma atuação mais garantista do Estado, que transpusesse as barreiras formais para, então possibilitar a efetiva proteção e a satisfação de

\footnotetext{
${ }^{14}$ Nesse sentido, JORGE REIS NOVAIS destaca que o Estado absolutista pode ser divido em dois momentos: "uma primeira fase na qual o Estado é considerado um bem patrimonial do Príncipe e uma segunda fase - com apogeu no século XVIII -, designada como 'de polícia', na qual o Príncipe se assume plenamente na tarefa de prover a felicidade dos súditos e em que o anterior fundamento divino do poder é substituído por um fundamento racional". (Contributo para uma Teoria do Estado de Direito, 2006, p. 36).

${ }^{15}$ Direito Administrativo Ordenador, 1993, p. 9.

${ }^{16}$ Contributo para uma Teoria do Estado de Direito, 2006, p. 42.

${ }^{17}$ NOVAIS, Jorge Reis. Contributo para uma Teoria do Estado de Direito, 2006, p. 112.
} 
direitos individuais e coletivos. Aumenta-se a exigência pelo controle estatal de modo a limitar as ingerências. Nesse sentido, a introdução do viés democrático a esse Estado de Direito, com o tempo, torna-se inevitável. Aumenta-se, assim, a exigência de espaços em que os cidadãos possam participar na formulação de políticas públicas e na tomada de decisões administrativas, de modo que possam satisfazer os direitos individuais e fundamentais.

Como ressalta MARÇAL JUSTEN FILHO, a construção teórica do direito administrativo retrata uma "lenta e inevitável transição do autoritarismo para a democracia” em que o Estado de Direito Democrático retrata que “nenhum poder político pode ser legitimado sem respeito à soberania popular e aos direitos fundamentais ${ }^{18 ” . ~ A ~}$ ausência de espaços para a participação social caracteriza uma atuação mais autoritária, visto que não se possibilita a interação entre as esferas pública e privada.

Desse modo, a participação torna-se um pressuposto para uma democracia efetiva e para suplantar-se o Estado autoritário. No entanto, para que isso seja possível devem ser disponibilizados meios que não restrinjam essa participação a um procedimento meramente formal $^{19}$. Como destaca ROBERTO DROMI: “O homem deve ser partícipe da gestão pública em seus distintos níveis institucionais (...) para tanto é necessário que os cidadãos tenham à disposição meios adequados para uma ampla participação ${ }^{20, "}$ (tradução livre).

\subsection{O processo de transição da atuação administrativa unilateral para uma atuação consensual}

O direito administrativo relaciona-se ao modo de atuação da Administração Pública, o que se vincula diretamente ao modelo estatal. O contexto de formação da atividade administrativa remete ao período de consolidação do Estado de Direito, em que um conjunto de normas é imposto como limitação ao Estado e garantia de proteção ao cidadão $^{21}$. No sentido de que o poder público seria limitado, tendo de submeter-se às normas jurídicas, ao princípio da legalidade, para que fossem garantidos os direitos dos indivíduos ${ }^{22}$.

\footnotetext{
${ }^{18}$ Curso de Direito Administrativo. 10. ed., 2014, p. 104.

${ }^{19}$ DROMI, Roberto. Derecho Administrativo. 6. ed., 1997, p. 83.

${ }^{20}$ Derecho Administrativo. 6. ed., 1997, p. 108.

${ }^{21}$ O direito torna-se, nos dizeres de FLORIANO DE AZEVEDO MARQUES NETO, “legatário do processo de universalização da legalidade e de superação das imunidades do poder aos limites e controles ditados pelo direito" (A concessão como instituto do direito administrativo, 2013, p. 499).

${ }^{22}$ MEDAUAR, Odete. Direito Administrativo Moderno. 18. ed., 2014, p. 41.
} 
Nesse sentido MARIA SYLVIA ZANELLA DI PIETRO e WALLACE PAIVA MARTINS JUNIOR destacam que:

"A formação do direito administrativo, como ramo autônomo, teve início (...) a partir do momento em que começou a desenvolver-se (...) o conceito de Estado de Direito, estruturado sobre o princípio da legalidade (em decorrência do qual até mesmo os governantes se submetem à lei, em especial à lei fundamental que é a Constituição) $e$ sobre o princípio da separação de poderes, que tem por objetivo assegurar a proteção dos direitos individuais, não apenas nas relações entre particulares, mas também entre estes e o Estado ${ }^{23}$.”.

Mas com o tempo o indivíduo passa a perder importância na construção do direito administrativo transformado o modelo assecuratório de liberdade num modelo que visa a efetivar o poder da autoridade ${ }^{24}$. Como um reflexo desse modelo autoritário, a Administração passa a adquirir uma posição de superioridade em face aos cidadãos, tidos como "administrados". Desse modo, a atividade administrativa passou a centrar-se na oposição entre público e privado. Os critérios que embasavam um direito administrativo supostamente protetivo servem para justificar um aumento do poder da autoridade ${ }^{25}$.

O paradigma que foi se construindo atribui uma importância exacerbada à unilateralidade e impõe um regime jurídico exorbitante para fundamentar a atuação administrativa. Assim, conferem-se à Administração algumas prerrogativas extraordinárias da administração, a presunção de legitimidade e a executoriedade de suas decisões, atribuise ainda como traço distintivo a noção de supremacia e de indisponibilidade do interesse público $^{26}$.

Tais construções jurídicas permitem à Administração Pública relacionar-se com o particular em posição hierarquicamente superior, sob a justificativa de atendimento do

\footnotetext{
${ }^{23}$ Teoria Geral e princípios do Direito Administrativo, 2014, p. 39.

${ }^{24}$ MARQUES NETO, Floriano de Azevedo. A concessão como instituto do direito administrativo, 2013, p. 499.

${ }^{25}$ Nesse sentido, ALEXANDRE SANTOS DE ARAGÃO destaca: "Não estamos aqui a afirmar que a separação de poderes e o princípio da legalidade a ela inerentes não têm a sua importância. De forma alguma. Continuam sendo elementos fundamentais para a própria existência do Direito Administrativo. Mas hoje devem ser atualizados de sua versão oitocentista para uma noção de divisão não estanque de funções estatais, que visa a uma repartição do trabalho e uma coibição da concentração do poder" (Curso de Direito Administrativo. 2. ed., 2013, p. 9).

${ }^{26}$ Nesse sentido explica JULIANA BONACORSI DE PALMA: “Dessa forma, além de legitimar a previsão de cláusulas exorbitantes nos contratos administrativos e a imperatividade nos atos administrativos, a prerrogativa imperativa também termina por afirmar no plano concreto a supremacia da Administração Pública" (Atuação administrativa consensual. Estudo dos acordos substitutivos no processo administrativo sancionador, 2010, p. 62).
} 
interesse público e da consecução de suas atividades ${ }^{27}$. No entanto, esse direito tende muito mais a efetivar o poder da Administração do que garantias e proteções aos particulares ${ }^{28}$. Como destaca JULIANA BONACORSI DE PALMA as prerrogativas extraordinárias prestam um caráter funcional à atuação administrativa, conferindo autoridade, legitimidade e presunção de legitimidade, que são elementos essenciais para uma atuação administrativa autoritária ${ }^{29}$.

Assim a Administração Pública constrói um modelo de atuação que se desloca do eixo inicialmente almejado, que era de proteção ao cidadão, a outro que visa à subordinação em face desses atos e interesses. Nesse sentido destaca FLORIANO DE AZEVEDO MARQUES NETO:

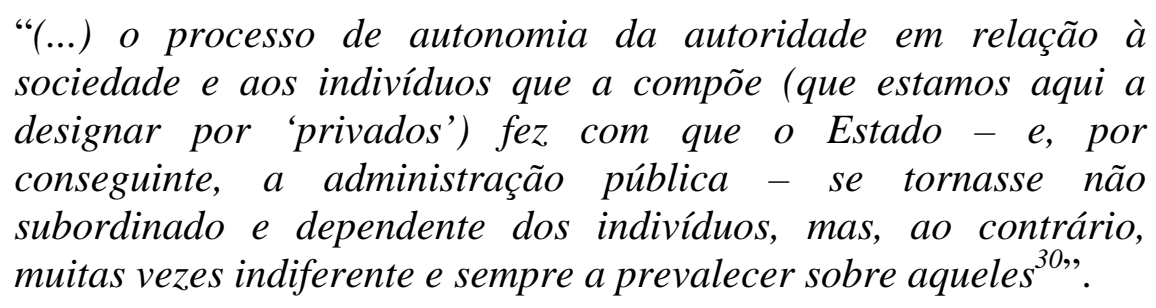

ROBERTO DROMI enfatiza que as prerrogativas da administração devem ser encaradas com ressalvas, visto que podem propiciar a arbitrariedade da Administração. O autor exemplifica isso ao destacar que a presunção de legitimidade constitui uma prerrogativa que pode ter consequências graves, porque “(...) significa proteger $a$ arbitrariedade administrativa, facilitando o excesso de poder e a dificuldade de efetiva

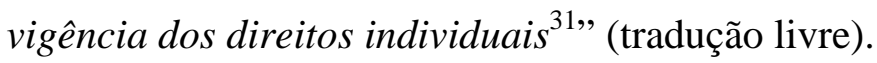

O contexto de transformações dos paradigmas estatais, a exemplo da transição para o Estado regulador, faz com que esse modelo de organização estatal e administrativa

27 Em sentido diverso argumenta JEAN RIVERO: "Poder-se-iam multiplicar os exemplos destas derrogações ao direito comum que tornam a Administração não mais poderosa, mas sim vinculada, que os particulares entre si” (Direito Administrativo, 1981, p. 42).

${ }^{28}$ A respeito do tema, confira-se: "Vale notar que esse deslocamento não se deu em favor do soberano ou de uma retomada do absolutismo (...) Desenvolveu-se, sim, em favor da consecução de fins de interesse geral, da consecução do bem comum ou, se quisermos, do interesse público remotamente consagrado na lei. (...) Com o crescimento do rol de atribuições da administração e com o aumento de complexidade das funções administrativas, cada vez mais o comando legal se tornou aberto, franqueador de largas margens de liberdade para a administração agir; elegendo de forma unilateral o que seja o interesse público em concreto" (MARQUES NETO, Floriano de Azevedo. A concessão como instituto do direito administrativo, 2013, p. 505).

${ }^{29}$ Atuação administrativa consensual. Estudo dos acordos substitutivos no processo administrativo sancionador, 2010, p 65.

${ }^{30}$ A concessão como instituto do direito administrativo, 2013, p. 489.

${ }^{31}$ Derecho Administrativo. 6. ed., 1997, p. 247. 
necessite reformular-se. Assim impõe-se a alteração do modelo de atividade administrativa burocrática, hierárquica, unilateral ${ }^{32}$ e centralizada na satisfação do interesse público tido como um interesse unitário ${ }^{33}$.

A função reguladora e os instrumentos contratuais permitem ao Estado aumentar a colaboração da organização privada no atingimento dos anseios sociais ${ }^{34}$. Com isso aumenta-se a necessidade de inter-relação entre a esfera pública e privada. Para isso a participação efetiva da sociedade na tomada de decisões passa a ser um elemento fundamental para a composição de interesses.

A alteração do paradigma da unilateralidade deve conduzir a um contexto em que se permita a conjugação das atuações pública e privada em cooperação, aumentando os espaços de negociação para que os processos de decisão da administração sejam influenciados pela sociedade $\mathrm{civil}^{35}$.

Essa transição de um paradigma mais autoritário para um consensual, portanto, não impede que os interesses coletivos e individuais sejam satisfeitos, mas afasta o modelo de superioridade. Como bem destaca FLORIANO DE AZEVEDO MARQUES NETO: “O reconhecimento da impossibilidade de se edificar uma Teoria do Estado centrada na ideia de homogeneidade, universalidade e singularidade de interesse público nada tem a ver com a imprescindibilidade de o poder público manter-se na tutoria dos interesses públicos $^{36,}$.

Além disso, essa alteração não visa à supressão do modelo autoritário por si só, mas revigorar a sua aplicabilidade e sua delimitação por meio de critérios que balizem a sua utilidade. Como destaca CARLOS ARI SUNDFELD: “Claro que existem boas razões

\footnotetext{
${ }^{32}$ Alguns autores já se manifestam nesse sentido, confira-se: "Em matéria de contratos administrativos, não se nega a existência de prerrogativas especiais da Administração, que são exatamente os fatores de diferenciação entre tais contratos e os contratos regidos pelo direito civil, mas é certo que tais prerrogativas são limitadas por uma série de direitos e garantias dos particulares contratantes, merecendo especial destaque o princípio da segurança jurídica" (DALLARI, Adilson Abreu. Anulação do contrato administrativo, 2013, p. 31). Nesse sentido também se veja: MOREIRA NETO, Diogo Figueiredo. O futuro das cláusulas exorbitantes nos contratos administrativos, 2008, p. 571-592.

${ }^{33}$ Como bem destaca FLORIANO DE AZEVEDO MARQUES NETO: "Necessário, portanto, apartar o colapso do modelo autoritário e centralizado do poder decisório enfeixado no Estado do singelo e perigoso discurso de sua redução a fórceps, ou de sua radical substituição pelos espaços privados ou da sua transformação em mera arena de mediação de interesses especiais" (Regulação estatal e interesses públicos, 2002, p.176).

${ }^{34}$ ORTIZ, Gaspar Ariño. Principios de Derecho Público Económico. Modelo de Estado, Gestión Pública, Regulación Económica. 3. ed., 2004, p. 312.

${ }^{35}$ Isso conduz ao que JACQUES CHEVALLIER define de governança pública: “A lógica da governança conduz (...) a ir além dessa associação dos grupos de interesses, ampliando o círculo dos atores envolvidos $e$ criando novos lugares de troca: um espaço de 'debate'(...) a surgir antes do espaço negociação, trata-se de abrir os processos decisionais para a 'sociedade civil', de escutar a 'voz do cidadão"' (A Governança e o Direito, 2005, p. 112-113).

${ }^{36}$ Regulação estatal e interesses públicos, 2002, p. 176.
} 
para defender as prerrogativas do Estado, mas estas não são criação humana, não fazem parte da ordem natural das coisas ${ }^{37}$ ”. Desse modo, as construções teóricas não podem esvaziar a satisfação concreta dos interesses sociais, mas será preciso se delimitar quando e por qual motivo um regime jurídico exorbitante será aplicado, sem que o interesse público se fundamente por si sós ${ }^{38}$.

Cria-se, assim, espaço para utilização de instrumentos variados, impositivos e consensuais, que possibilitem uma atuação mais equilibrada da Administração na consecução dos fins a que se propõe a realizar. Essa concepção impõe ainda se identificar um novo delineamento à atuação pública e privada.

\subsubsection{O delineamento das atuações pública e privada}

Uma das delimitações mais referidas para diferenciar público e privado é que o primeiro envolve a atuação do Estado na consecução de interesses públicos coletivos e o segundo se relaciona aos interesses egoísticos do particular. No entanto, essa diferenciação é bastante tênue na prática, o que dificulta uma classificação nesses moldes.

Um exemplo disso é que, em alguns casos, o próprio Estado atua no domínio privado para satisfação de interesses igualmente privados, a exemplo das empresas públicas e sociedades de economia mista. Por outro lado, no domínio privado há incentivos às ações de cunho promocional, como o fomento, que tendem a mitigar a utilização do poder de autoridade em relação aos particulares ${ }^{39}$. Como explica JEAN RIVERO:

\footnotetext{
"A diferenciação entre atividades públicas e privadas atenuou-se: doravante exercem-se frequentemente no mesmo domínio, o que faz com que utilizem processos jurídicos idênticos. É fácil ver pessoas privadas associadas a tarefas de interesse geral e dotadas, para esse efeito, de prerrogativas de poder público. (...) Por fim, as relações dos particulares com a Administração também se diferenciaram: ao lado das relações de sujeição, nas quais o particular aparece como administrado, criaram-se situações nas quais possui, na qualidade de utente do serviço, um poder de exigir, e situações de colaboração ${ }^{40-41, "}$
}

\footnotetext{
${ }^{37}$ Direito Administrativo para Céticos, 2012, p. 41.

${ }^{38}$ SUNDFELD, Carlos Ari. Direito Administrativo para Céticos, 2012, p. 41.

${ }^{39}$ CASSAGNE, Juan Carlos. Derecho Administrativo. 5. ed.,1996, p. 50.

${ }^{40}$ Direito Administrativo, 1981, p. 33.

${ }^{41}$ Aqui cabe ressaltar que embora esse autor reconheça a fluidez inerente à separação entre público e privado, entende que se aplica, como um traço distintivo entre as duas esferas, um regime de prerrogativas extraordinárias.
} 
Além disso, a atuação pública existe como um fim instrumental à satisfação dos direitos e interesses dos cidadãos e da comunidade ${ }^{42}$. Ou seja, a Administração Pública deve atuar como “gestora de interesses”, no sentido de operacionalizar a concreção desses interesses, sendo preciso que esteja vinculada, portanto, ao que "os titulares desses interesses decidam ${ }^{43}$,.

A atuação da esfera pública, dessa maneira, pressupõe a observância às necessidades de existência individual, o que envolve um processo de interação entre essas esferas $^{44}$. Alguns autores chegam inclusive a aludir à existência complementar entre o setor público e privado ${ }^{45-46}$.

Como menciona VASCO MANUEL PASCOAL DIAS PEREIRA DA SILVA: “Existe, pois, comunicação (e não separação) entre os interesses dos particulares e das autoridades administrativas ${ }^{47,}$. Os interesses públicos e privados, portanto não devem ser observados aprioristicamente como antagônicos. Os antagonismos podem ser verificados, é claro, mas isso se dá não apenas entre interesse público e privado, mas também entre os próprios interesses privados. Na própria esfera privada existem interesses contrapostos, o que é inerente à própria dinâmica social. Nessa linha destaca JUAN CARLOS CASSAGNE: “A busca de um critério uniforme e universal de diferenciação entre os direitos público e privado deve ser abandonada como objetivo (...) não se trata, então, de estabelecer uma classificação a priori sem analisar a realidade jurídica concreta em cada

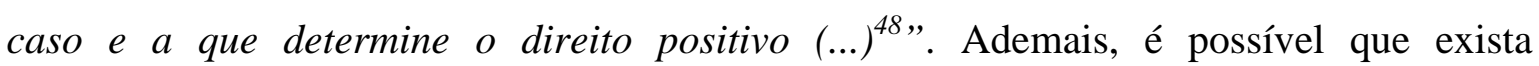
contraposição entre interesses públicos.

E todos esses interesses se alteram ao longo do tempo, acompanhando as modificações sociais, o que torna inviável se proceder a uma atuação puramente abstrata para definir a delimitação das esferas pública e privada. Além do que o aumento ou a

\footnotetext{
42 DROMI, Roberto. Derecho Administrativo. 6. ed., 1997, p. 107.

43 MATEO, Ramón Martín. Manual de Derecho Administrativo. 25. ed., 2006, p. 28.

44 Nessa linha, confira-se: “Não é possível se conceber a atividade da Administração pública (e, por conseguinte, o direito administrativo) apartada dos privados e alheia a eles. Só faz sentido conceber o Estado-administração se considerarmos sua relação com os particulares, se reconhecermos que seus confins são ditados exatamente pela interface com os direitos e interesses dos indivíduos”. (MARQUES NETO, Floriano de Azevedo. A concessão como instituto do direito administrativo, 2013, p. 509).

${ }^{45}$ DROMI, Roberto. Derecho Administrativo. 6. ed., 1997, p. 89.

46 JEAN RIVERO chega a destacar que “(...) as normas do direito administrativo caracterizam-se em face das do direito privado”. (Direito Administrativo, 1981, p. 42).

47 Em busca do acto administrativo perdido, 1996, p. 425.

${ }^{48}$ Derecho Administrativo. 5. ed., 1996, 52.
} 
redução da dicotomia entre essas esferas também dependerá do modelo estatal adotado ${ }^{49,}$, o que varia ao longo do tempo.

\subsection{As diferentes demandas da sociedade civil}

A sociedade civil é composta por diversos agentes, - desde empresários até os cidadãos -, os quais possuem os mais diversos interesses. Cada um dos grupos sociais ou econômicos tende a "fazer valer" seus interesses em face da decisão administrativa ${ }^{50}$. E assim se coloca à Administração a questão de como compatibilizar e operacionalizar esses diversos interesses.

Como bem destaca PAULO OTERO: com o aprofundamento da noção democrática e de participação social amplia-se a relação entre o Estado e a sociedade na consecução dos objetivos traçados pelo Estado. Isso como decorrência da insuficiência dos mecanismos representativos de darem conta de compor interesses contraditórios e concorrentes $^{51}$.

Assim, o Estado passa a ter de compor os diversos interesses econômicos, sociais e culturais que tentam fazer-se representados ${ }^{52}$. Com isso "transforma a própria

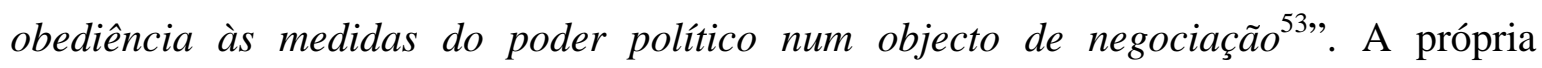
modulação do que seja o “interesse público” perpassa pela composição de antagonismos entre os diversos grupos de interesses, o que exige a implementação de uma política de 'concertação social', que visa a obter o consenso entre os interessados na composição dos diversos interesses em causa ${ }^{54}$.

Não existe um modo satisfatoriamente adequado de se definir aprioristicamente quais interesses devem prevalecer, de modo que sempre seja preciso fixar: (i) o objeto de

\footnotetext{
${ }^{49}$ Como muito bem acentua FLORIANO DE AZEVEDO MARQUES NETO: “(...) há a percepção pelo próprio Estado da necessidade de aprofundar os mecanismos de atribuição a entes privados da tarefa de prover... interesses. $O$ uso crescente de instrumentos de cooperação e delegação a iniciativa privada é ilustrativo do que se disse. O que implica uma requalificação da separação entre esfera pública e esfera privada e o redimensionamento do papel de cada uma delas na consecução do interesse público" (La moderna regulación: la búsqueda de un equilibrio entre lo público y lo privado, 2011, 1091).

${ }^{50}$ OTERO, Paulo. Legalidade e Administração Pública. O sentido da vinculação administrativa à juridicidade, 2007, p. 140.

${ }^{51}$ Legalidade e Administração Pública. O sentido da vinculação administrativa à juridicidade, 2007, p. 140.

${ }^{52}$ Acentua-se a posição da Administração Pública em sua atuação "compatibilizar os interesses dos distintos setores sociais", visto que "o pluralismo imposto pela sociedade é pressuposto obrigatório da participação" (tradução livre). (DROMI, Roberto. Derecho Administrativo. 6. ed., 1997, p. 83).

${ }^{53}$ OTERO, Paulo. Legalidade e Administração Pública. O sentido da vinculação administrativa à juridicidade, 2007, p. 141.

${ }^{54}$ OTERO, Paulo. Legalidade e Administração Pública. O sentido da vinculação administrativa à juridicidade, 2007, p. 141.
} 
atuação, (ii) os objetivos a serem atendidos, (iii) as partes interessadas ou afetadas e (iv) quais normas se aplicam ao caso, para que se efetuar essa delimitação dos interesses em causa. Isso se impõe inclusive em razão da contínua modificação por que passam os interesses sociais e a própria delimitação da atuação da Administração.

A determinação da composição de interesses e a influência que cada um deles exercerá serão balizadas pelos preceitos constitucionais. Nessa linha pondera RAMÓN MARTÍN MATEO: “Não existe, em princípio, uma definição que possa valer para todos os (...) interesses que a Administração deva tutelar. Isso é matéria de decisão fundamentalmente política. A Administração poderá selecionar parcelas determinadas de interesses públicos, mas deverá para isso ater-se ao marco constitucional, a ordem básica das decisões políticas ${ }^{55,}$.

Assim, dificulta-se a manutenção de uma atuação fragmentada entre o setor público e o setor privado e noção de um interesse público tido como único. Inicia-se, desse modo, a superação da clássica noção de antagonismo das esferas pública e privada que

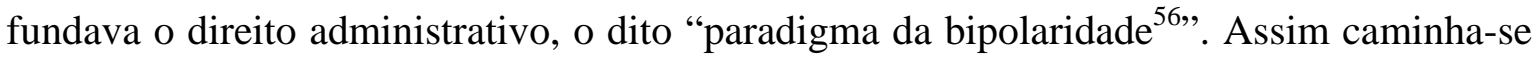
para um contexto de composição de interesses em que não há “prevalência ou prioridade”, que são fruto de um conflito, que exige uma composição de interesses ${ }^{57}$.

\subsubsection{A existência de uma multiplicidade de interesses}

Como bem destaca JOSÉ EDUARDO FARIA a ordem socioeconômica tem se tornado cada vez mais multifacetada e policêntrica, o que dificulta a operacionalização do direito de modo unidirecional e individualizado. Os conflitos passam assumir um caráter pluridimensional e impõem a solução de uma multiplicidade de interesses e reivindicações $^{58}$. Com isso aumenta-se o nível de complexidade das decisões administrativas, que passam a exigir uma composição de diferentes interesses, que se colocam em nível de igualdade e os quais podem ou não convergir ${ }^{59}$. No caso de haver contraposição surgirá o impasse: “como se definir qual interesse tem de prevalecer?”.

\footnotetext{
${ }^{55}$ Manual de Derecho Administrativo. 25. ed., 2006, p. 29.

56 Nesse sentido, confira-se: GIANNINI, Massimo Severo. Il potere discrezionale della pubblica amministrazione, 1939 e CASSESE, Sabino, L'arena pubblica. Nuovi paradigmi per lo Stato, 2001.

${ }^{57}$ MARQUES NETO, Floriano de Azevedo. A concessão como instituto do direito administrativo, 2013, p. 512.

58 O Direito na Economia Globalizada, 2000, p. 15.

59 “Ante a existência de múltiplos elementos decisórios decorrentes da fragmentação social e de uma diversidade de efeitos conexos ao específico modo de agir administrativo, constata-se a complexidade da atuação administrativa” (PALMA, Juliana Bonacorsi de. Atuação administrativa consensual. Estudo dos acordos substitutivos no processo administrativo sancionador, 2010, p. 56).
} 
Essa conjuntura faz repensar-se o paradigma da bipolaridade que, até então, estava consolidado na fórmula genérica do interesse público em contraposição com o interesse privado. Assim, o Estado necessita encontrar mecanismos que mitiguem a imperatividade. Afinal, torna-se muito mais complexo encontrar uma solução adequada ${ }^{60}$.

Uma das possíveis fórmulas encontradas é a adoção de instrumentos consensuais como forma de valorização de um modelo em que haja uma multiplicidade de interesses a serem compostos e satisfeitos ${ }^{61}$. O que abre espaço para uma “Administração Pública dialógica, a qual contrastaria com a Administração pública monológica, refratária à

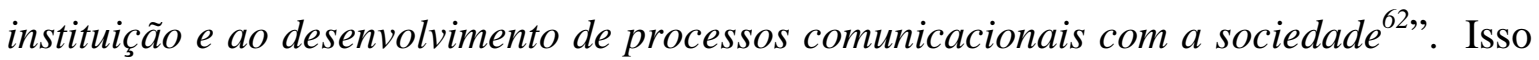
por se compreender que a adoção conjunta de métodos consensuais pode permitir a composição de interesses que conflitam. No entanto, como isso não se quer dizer que o consenso reduza o conflito a uma única solução, pois é possível que sejam adotadas diferentes soluções, que melhor conciliem os interesses.

\subsubsection{Impossibilidade de enclausuramento de interesses sob a clássica fórmula do “interesse público”}

Há algumas construções teóricas que são importantes para o direito administrativo, mas que requerem releituras e mitigações em sua abrangência para se adequaram “à dimensão constitucional e democrática”" ${ }^{\text {"63 }}$. Uma dessas teorizações é o interesse público.

Como visto, a composição social é bastante diversificada, de modo que os interesses dificilmente poderão ser simplesmente consolidados em um único interesse. Desse modo, definir o que seja interesse público e alçá-lo a essa condição requer selecionar dentre os diversos interesses quais serão as necessidades a serem satisfeitas.

\footnotetext{
${ }^{60}$ Nessa linha, confira-se: 'Sabino Cassese demonstra como o modelo (que ele chama de 'paradigma') bipolar cede espaço e deve ser superado por um novo paradigma, que denomina de 'arena pública'. Reportando-se aos ensinamentos de Massimo Severo Giannini, Cassese demonstra que os pressupostos do modelo bipolar não mais se sustentam. (...) o fundamento na legalidade como fonte e vínculo da ação administrativa e a unicidade do interesse público não são mais compatíveis com uma realidade (...) produto de um conflito de interesses" (MARQUES NETO, Floriano de Azevedo. A concessão como instituto do direito administrativo, 2013, p. 512. p. 512).

${ }^{61}$ A adoção de mecanismos consensuais não elimina a possibilidade de serem adotados outros de cunho impositivo, mas é um modo alternativo de composição de interesses, que pode produzir bons resultados na consecução dos objetivos pretendidos pela sociedade e pelo Estado.

${ }^{62}$ OLIVEIRA, Gustavo Justino; SCHWANKA, Cristiane. A Administração Consensual como a nova face da Administração Pública no Séc. XXI: Fundamentos dogmáticos, formas de expressão e instrumentos de ação, 2009, p. 131.

63 JUSTEN FILHO, Marçal. Curso de Direito Administrativo. 10. ed., 2014, p.105.
} 
Como explica FLORIANO DE AZEVEDO MARQUES NETO, é necessário afastar-se, portanto, da “(...) dependência de um conceito único e totalizante de vontade geral ou de interesse público, o Estado republicizado deve se ater ao reconhecimento da pluralidade de interesses públicos ${ }^{64, ”}$. Essa necessidade de compor os mais diversos interesses exige uma ação de demonstração do Poder Público de qual o motivo em adotar determinada solução em detrimento de outra que também satisfaz as necessidades coletivas. Nesse sentido prossegue o referido professor: “(...) Num Estado republicizado a legitimação da ação do poder político depende, permanentemente, da capacidade de demonstrar, discursivamente, o porquê da ação desigual no sentido de privilegiar um ou outro interesse público em confronto ${ }^{65}$,.

A noção de um interesse público como um valor supremo é uma construção teórica que ignora a pluralidade de interesses existentes e a necessidade de uma composição coordenada desses interesses. Nesse sentido bem explica ODETE MEDAUAR:

\begin{abstract}
“Esse 'princípio' [supremacia do interesse público sobre o privado], se algum dia existiu, está ultrapassado, por várias razões (...) Mostra-se pertinente à Constituição de 1988 e à doutrina administrativa contemporânea a ideia de que à Administração cabe realizar a ponderação de interesses numa determinada situação, para que não ocorra sacrifício a priori de nenhum interesse; o objetivo desta função está na busca de compatibilidade ou conciliação dos interesses, com a minimização de sacrifícios ${ }^{66}$."
\end{abstract}

Nesse mesmo sentido ANTONIO CARLOS CINTRA DO AMARAL ressalta que se deve ter cautela quanto à noção de indisponibilidade do interesse público e na clássica dicotomia interesses públicos primários e secundários ${ }^{67}$, porque não existe “ $a$ sociedade

\footnotetext{
${ }^{64}$ Regulação estatal e interesses públicos, 2002, p.179.

${ }^{65}$ Regulação estatal e interesses públicos, 2002, p.179.

${ }^{66}$ Direito Administrativo Moderno. 18. ed., 2014, p. 149.
}

67 Para diferenciar os direitos em causa costuma-se aludir com frequência à divisão clássica de interesse público primário e interesse público secundário. No primeiro caso, enquadram-se aqueles direitos que se vinculam diretamente a interesses coletivos. No segundo caso, vinculam-se os interesses da Administração enquanto pessoa jurídica. Nos dizeres de CELSO ANTÔNIO BANDEIRA DE MELLO: “Interesse público ou primário, repita-se, é o pertinente à sociedade como um todo, e só ele pode ser validamente objetivado, pois este é o interesse que a lei consagra e entrega à compita do Estado como representante do corpo social. Interesse secundário é aquele que atina tão-só ao aparelho estatal enquanto entidade personalizada (...) que só pode ser validamente perseguido pelo Estado quando coincidente com o interesse público primário. (...) não há coincidência necessária entre interesse público e interesse do Estado e demais pessoas de Direito Público (...) o Estado, concebido que é para realização de interesses públicos (situação, pois, diversa da dos particulares), só poderá defender seus próprios interesses privados quando, não se chocarem com os interesses públicos propriamente dito" (MELLO, Celso Antônio Bandeira de. Curso de Direito Administrativo, 27. ed., 2010, p. 66). Tal classificação é oriunda da doutrina italiana. Nesse sentido 
como um todo”, ${ }^{\text {, }}$, para que se possam qualificar os interesses primários, visto que os interesses são fragmentados, múltiplos ${ }^{69}$.

HUMBERTO BERGMANN ÁVILA enfatiza que é impensável se defender o postulado da supremacia do interesse público sobre o privado, na medida em que não existe uma mera relação de contraposição entre esses interesses, vez que os interesses se inter-relacionam ${ }^{70}$. Para esse autor, deixar de pensar em uma ponderação dos interesses que reciprocamente se relacionam ${ }^{71}$ impossibilita encontrar-se a solução mais adequada a cada caso concreto. Afinal, dentre as mais diversas opções possíveis irá se optar uma solução ignorando-se as demais como se também não o fossem satisfazer às necessidades coletivas.

A crítica à visão clássica do interesse público é pela sua limitação em conter toda a realidade e colocar um valor acima de outros que também pode ser igualmente relevantes, sem que com isso se imponha um privilégio aos direitos individuais ou privados em detrimento de outros direitos.

A consideração da primazia de um interesse público como um valor superior, portanto, deve ser mitigada por ser insuficiente para demonstrar as soluções mais adequadas diante do embate entre os mais diversos interesses públicos ${ }^{72}$. Desse modo, a defesa de um "interesse público" totalizante acaba por restringir direitos e garantias

RENATO ALESSI define: "La peculiarità della pubblica Amministrazione sta appunto in ciò, che la sua funzione consiste nella realizzazione dell'interesse collettivo, pubblico, primario. Anche volendosi concepire un interesse, secondario, dell 'Amministrazione considerata comme apparato organizzativo autônomo (...)". (Principi di diritto amministrativo. 4. ed., 1978, p. 232-233).

${ }^{68}$ Em sentido contrário, posiciona-se JOSÉ DOS SANTOS CARVALHO FILHO: “A 'desconstrução' do princípio [supremacia do interesse público sobre o privado] espelha um visão distorcida e coloca em risco a própria democracia; o princípio, isto sim, suscita 'reconstrução, vale dizer, adaptação à dinâmica social (...) Com a vênia aos que perfilham visão oposta, reafirmamos a nossa convicção de que, malgrado todo o esforço em contrário, a prevalência do interesse público é indissociável do direito público" (Manual de Direito Administrativo. 27. ed., 2014, p. 34-35).

${ }^{69}$ AMARAL, Antonio Carlos Cintra do, O princípio da publicidade no direito administrativo, 2003, p. 11-12.

${ }^{70}$ Esse autor ainda destaca que a relação de proximidade entre o interesse privado e o público já é definida pela própria Constituição brasileira, o que de fato impede que sejam separadamente descritos na análise da atividade estatal e de seus fins. (Repensando o "Princípio da Supremacia do Interesse Público sobre o Particular", 1998, p.167).

${ }^{71}$ Nesse mesmo sentido PEDRO A. BATISTA MARTINS menciona: "O interesse público e o privado se embricam (sic). Aqueles são fortalecidos e revigorados por uma atuação constante destes. O interesse público não se descola, não se afasta, não despreza a finalidade privada. Ao contrário, com ela se toca, nela se permeia, converge e se condensa numa única manifestação de interesse". (MARTINS, Pedro A. Batista. Arbitrabilidade objetiva, Interesse Público, indisponibilidade de direitos e normas de ordem pública. Grandes Temas da Atualidade, 2008, p. 258).

${ }^{72}$ Outra critica que se pode mencionar é que a identificação do que seja interesse público não se vinculada à titularidade estatal para ser reconhecido como tal. Nesse sentido adverte MARÇAL JUSTEN FILHO que se configura uma "inversão lógica e axiológica" insuperável definir o interesse público pela identidade do titular que o executa. Afinal, o conceito de interesse público é anterior ao interesse estatal e não se torna público por ser atribuído a este, pelo contrário, é público e por isso é atribuído ao Estado (Conceito de Interesse Público e a "Personalização" do Direito Administrativo, 1999, p. 117). 
expressamente definidos aos indivíduos, sob a justificativa de satisfazer ao atendimento das necessidades coletivas ${ }^{73}$.

MASSIMO SEVERO GIANINNI apresenta uma concepção de delineamento do interesse público que tende a afastá-lo, portanto, de uma concepção genérica e apriorística. Nesse sentido, FRANCO GAETANO SCOCA sintetiza muito bem o entendimento daquele autor. Confira-se:

"Na concepção de Gianinni os interesses públicos são dados pelas leis; a administração deve (efetuar) uma avaliação conjunta $e$ compará-los. Isto significa que o interesse público que a administração efetivamente deve perseguir em qualquer ocasião não é um dos interesses públicos dados pela lei (nem o interesse primário e nem um dos interesses secundários) mas é um interesse (composto, misto, fruto da comparação ou compromisso) diversamente esculpido (ou construído) pela mesma administração através de operação de valoração comparativa [benchmarking]. Tal interesse público, que, para ser aderente à concreta situação, pode-se concordar em denominá-lo de interesse público concreto $^{74, "}$ (tradução livre).

A Administração Pública deve identificar quais são os interesses em causa, prosseguindo, então, à análise dos objetivos a serem atingidos de modo que seja possível atingir-se a uma decisão que melhor satisfaça os interesses desejados. Isso perpassa obrigatoriamente pela composição de interesses para se avaliar o que será ou não atendido.

Aliás, como enfatiza ALEXANDRE SANTOS DE ARAGÃO a alteração do enfoque do interesse público, ora demonstrada, não o coloca em segundo plano, pelo contrário, busca alcançar uma compatibilização com os interesses privados ${ }^{75}$, cabendo à Administração observar a totalidade dos interesses envolvidos no litígio e certificar-se de quais serão mais adequados para as satisfações que se pretende atingir.

\subsection{A questão da compatibilização de interesses presentes na sociedade civil}

Como ensina ODETE MEDAUAR, o direito administrativo tem se tornado muito mais flexível para que possa acompanhar as mudanças que ocorrem na realidade concreta.

\footnotetext{
${ }^{73}$ Nesse sentido, confiram-se autores como: ÁVILA, Humberto Bergmann, Repensando o "Princípio da Supremacia do Interesse Público sobre o Particular”, 1998, p.159-179; ARAGÃO, Alexandre Santos de, O princípio da proporcionalidade no Direito Econômico, 2001, p. 212-215 e SCHIER, Paulo Ricardo, Ensaio sobre a Supremacia do Interesse Público sobre o Privado e o Regime Jurídico dos Direitos Fundamentais, 2004, p. 167-185.

${ }^{74}$ La discrezionalità nel pensiero di Giannini e nella dottrina successiva, 2000, p. 1070.

${ }^{75}$ O princípio da proporcionalidade no Direito Econômico, 2001, p. 230.
} 
Tanto a esfera pública quanto privada tende a sofrer uma aproximação, passando a conviver de forma mais intensa, sendo necessário ponderar os interesses em confronto ${ }^{76}$.

Isso faz com que se caminhe para um modelo de organização estatal e também socioeconômico, que possibilite a conjugação de atuações públicas e privadas na consecução das políticas públicas desejadas. Essa aproximação dos setores público e privado tem tornado cada vez mais imprescindível uma atuação compartilhada de ambos os setores. E porque se verifica tal circunstância?

Em geral porque a interação entre todos os interessados contribui para a adoção de decisões que tendem a ser mais adequadas às necessidades coletivas que se objetiva satisfazer. Nos dizeres de DIOGO DE FIGUEIREDO MOREIRA NETO, seria “um aprimoramento da governabilidade dos Estados contemporâneos" ${ }^{\text {77, }}$, com vistas a uma prestação mais eficiente de suas atividades. Ademais, os recursos exigidos para a prestação de atividades pelo Estado são maiores do que este pode suportar.

Esse crescimento e expansão das atividades conjuntas da iniciativa privada e setor público demonstram que o modelo de organização estatal sofreu modificações, não havendo mais a imposição de atuação fragmentada entre o setor público e o setor privado, como se fossem sempre guiados por interesses antagônicos. Evidentemente que possuem diferenciações, mas elas podem ser compatibilizadas ${ }^{78}$ para o bom desenvolvimento social, econômico e até mesmo político, sobretudo ante a escassez de recursos.

\subsection{A adoção do método consensual na relação entre Administração Pública e particulares}

A prática da atividade estatal continua, de certo modo, a refletir uma noção de superioridade do Estado em relação aos cidadãos. Há uma tendência muito forte de se conceber a legitimidade das relações travadas entre a Administração Pública e a sociedade sob um viés unilateral e de imposição por parte do Poder Público. Essa noção de relação hierárquica reduz a legitimidade e validade dos atos estatais, porque tais atos são dependentes da participação dos cidadãos a cujos interesses se pretendem satisfazer.

\footnotetext{
${ }^{76}$ Direito Administrativo Moderno. 18. ed., 2006, p. 42.

${ }^{77}$ Curso de Direito Administrativo. 15. ed., 2009, p. 82.

${ }^{78}$ Menciona-se “podem ser”, porque se reconhece que em algumas circunstancias os interesses podem ser inconciliável.
} 
A adoção de um método consensual é, portanto, resultado de um processo de reformulação da atividade administrativa que se desloca de um eixo unilateral para outro multifacetado ${ }^{79}$.

Mas para que essa relação se desenvolva de melhor modo se percebe que ainda é preciso caminhar bastante para se equalizar a relação desenvolvida dentro do corpo social, pelo Estado, pela sociedade civil, composta pelos cidadãos e pelos setores econômicos, sem que um possa se sobrepor ao outro em situações que possam ser compatibilizadas.

O respeito à transparência nas escolhas políticas e à participação popular já começam a ser vistas hoje como requisitos para a construção desse novo modelo de Administração $^{80}$. Já são apontadas inúmeras vantagens na criação de mecanismos consensuais em comparação com aqueles imperativos que, via de regra, servem para caracterizar a atuação administrativa ${ }^{81}$.

A noção de horizontalidade nas relações entre os setores públicos e privados é uma exigência premente, tendo em vista que existem diversos interesses em causa e que o Estado sozinho não consegue efetivá-los. Como leciona MARIA SYLVIA ZANELA DI PIETRO: “A participação popular na gestão e no controle da Administração Pública constitui o dado essencial que... corresponde às aspirações do indivíduo de participar... da defesa da imensa gama de interesses públicos que o Estado, sozinho, não pode proteger" ${ }^{82}$.

\subsubsection{A função da consensualidade}

A função da consensualidade é possibilitar que o administrador observe a multiplicidade de interesses envolvidos para entender de que forma poderá melhor atendêlos. Sobretudo quando houver interesses conflitantes será necessário identificar e avaliar

\footnotetext{
79 Nesse sentido e em análise à figura contratual, VERA MONTEIRO diz: “É preciso desmistificar a natureza exorbitante do contrato administrativo, em prol do reconhecimento de uma relação contratual dialogada, marcada pela consensualidade e pela perda do autoritarismo gratuito” (Concessão, 2010, p. 69). ${ }^{80}$ Não há necessidade de que essa participação seja efetiva e real de cada cidadão, mas é preciso que exista possibilidade de que, quando desejada, essa participação possa ser realizada de modo adequado e suficiente para exposição de opiniões. Como destaca MARÇAL JUSTEN FILHO: "A validade dos atos estatais pressupõe um sistema jurídico que propicie a participação do cidadão na formação da vontade do Estado”. Como complementa esse autor, no sentido de que o "cidadão não é um súdito, um inferior, um servo do Estado”. Nesse sentido, estabelece-se uma relação de horizontalidade entre Estado e cidadãos. (Curso de Direito Administrativo. 10. ed., 2014, p. 103).

${ }^{81}$ Nessa linha: “(...) a autoridade tem cedido espaço para a introdução de mecanismos de consensualidade. Na medida em que a sociedade (ou ao menos os segmentos mais organizados dentro dela) se fortalece, mas inviável é a afirmação de que a esfera pública exclusivamente pela autoridade. Se faz necessário construir consensos que legitimem a intervenção estatal” (MARQUES NETO, Floriano de Azevedo. La moderna regulación: la búsqueda de un equilibrio entre lo público y lo privado, 2011, 1092).

${ }^{82}$ Participação popular na Administração Pública, 1993, p. 26-39.
} 
todos os interesses, fundamentando-se do melhor modo qual será ou deverá ser arbitrado pela Administração. Isso facilitará a delimitação de quais atividades serão expostas ou não a um regime derrogatório.

A consensualidade pode, portanto, ser compreendida como mecanismo de equilíbrio na atuação administrativa. De modo que a competência decisória deixe de decorrer exclusivamente de uma decisão impositiva. No entanto, essa possibilidade de composição de interesses possui limites, visto não pode ser utilizada para violação de direitos. O acordo prévio entre o poder público e os particulares não legitima o desrespeito a direitos ${ }^{83}$.

Mas com isso não se afasta a possibilidade de uma margem de discricionariedade para a Administração definir qual método produzirá melhores resultados, podendo ora definir uma atuação mais consensual ou impositiva ${ }^{84}$. Nesse sentido, a previsão de instrumentos normativos pode auxiliar nessa escolha ${ }^{85}$. O que não caberá é afastar-se uma atuação consensual por reputá-la como contraditória ao interesse público. Nessa linha destaca ODETE MEDAUAR:

“Não se mostra adequado invocar tal princípio [supremacia do
interesse \público] como impedimento à realização de acordos, à
utilização de práticas consensuais e da arbitragem pela
Administração. Na verdade, o interesse público realiza-se
plenamente, sem ter sido deixado de lado, na rápida solução de
controvérsias, na conciliação de interesses, na adesão de

${ }^{83}$ Pense-se no caso de um acordo entre Administração Pública e um determinado particular para não realização de licitação, quando presentes os requisitos exigidos pela lei. Ou, ainda, a celebração de termo de compromisso que abrande as regras previstas em acordos setoriais de logística reversa, visto que a lei impõe que esses termos deverão ser aplicados quando for necessário enrijecer tais acordos. Conforme disposto no art. 32, inc. II do Decreto 7.404/2010: "O Poder Público poderá celebrar termos de compromisso com os fabricantes, importadores, distribuidores ou comerciantes referidos no art. 18, visando o estabelecimento de sistema de logística reversa: (...) II - para a fixação de compromissos e metas mais exigentes que o previsto em acordo setorial ou regulamento".

${ }^{84}$ Nesse sentido destaca JULIANA BONACORSI DE PALMA: "Se a Administração Pública buscar aproximar o administrado de suas decisões, então o ato consensual será preferido. No entanto, se a proposta for afirmar a autoridade estatal, a sanção administrativa apresenta-se como o meio mais adequado para tanto". (Atuação administrativa consensual. Estudo dos acordos substitutivos no processo administrativo sancionador, 2010, p. 98).

${ }^{85}$ MARÇAL JUSTEN FILHO chega a destacar, inclusive, que a consensualidade, em alguns casos, pode ser imposta por lei. Nesse sentido, confira-se: "As alterações podem ser produzidas ou por acordo entre as partes ou mediante ato unilateral da Administração Pública. A distinção não significa que a alteração consensual seria facultativa, enquanto a unilateral seria compulsória. A alteração unilateral imposta pela Administração tem de ser acatada pelo particular. Podem ocorrer hipóteses em que a alteração consensual é compulsoriamente imposta por lei. Assim, por exemplo, é obrigatória a recomposição da equação econômico-financeira em caso de alteração unilateral. Mas essa recomposição se fará mediante acordo entre as partes" (Direito Administrativo. 10. ed., 2014, p. 540). 
particulares às suas diretrizes, sem ônus e a lentidão da via jurisdicional $^{86, "}$

A consensualidade pode ser utilizada em face de diferentes institutos, como o ato administrativo $^{87}$, o contrato administrativo ${ }^{88}$, o processo administrativo, em procedimentos de manifestação democrática, como audiências e consultas públicas.

\subsubsection{Ausência de redução do poder estatal}

A redução da atuação estatal como empresário e a liberalização de setores econômicos não implica a redução do poder estatal, porque é acompanhada pelo “alargamento do papel do Estado como regulador 89 ”. Ou seja, o Estado modifica a forma de intervenção, mas não a sua participação na modulação das atividades econômicas ${ }^{90}$.

MARÇAL JUSTEN FILHO, com base no escólio de PAOLO LAZZARA, enfatiza que a retirada da atuação direta do Estado não implica a redução da "garantia de realização dos direitos fundamentais”, mas tão somente modifica a forma de instrumentalização desses direitos ${ }^{91}$. O afastamento do Estado da produção de bens e da prestação de serviços é acompanhado pela regulação das atividades. Sob esse mesmo raciocínio, pode-se dizer que a proposição de um método consensual não implica a redução do poder estatal. Ou seja, o consenso visa a estabelecer uma relação de interação e comunicação entre as partes envolvidas ao longo do processo de tomada de decisões ou de realização das atividades administrativas, que seja diferenciada de uma lógica autoritária de imposição da decisão.

\footnotetext{
${ }^{86}$ Direito Administrativo Moderno. 18. ed., 2014, p. 150.

${ }^{87}$ LUCIANO PAREJO ALFONSO define o ato administrativo consensual como: “(...) o acordo de vontades entre uma Administração Pública e um ou vários sujeitos de Direito, regulado pelo Direito Administrativo, celebrado no contexto de um procedimento administrativo e através do qual aquela deve exercer uma potestade também administrativa (...) [dirigida] à constituição, modificação ou extinção de uma relação jurídica” (tradução livre). (Los actos Administrativos Consensuales en el Derecho Español, 2003, p. 17). 88 Nesse sentido e em análise à consensualidade contratual, destaca VERA MONTEIRO: "Vários mecanismos podem ser pensados para atingir tais desideratos. Alguns ligados à fase pré-contratual (como a audiência e consulta públicas e a promoção de manifestação de interesse); outros para serem aplicados no processo licitatório em si (e assumindo que a competição não é um mecanismo vantajoso em todos os casos); e outros, ainda, para serem inseridos no instrumento contratual (como a arbitragem, a mediação, a revisão periódica das condições contratualizadas, a repartição de riscos, o compartilhamento de ganhos econômicos, a maior participação dos financiadores na execução do contrato e a remuneração variável)" (Concessão, 2010, p. 59).

89 SANTOS, António Carlos dos; GONÇALVES, Maria Eduarda; MARQUES, Maria Manuel Leitão. Direito Económico. 4. ed., Coimbra: Almedina, 2001, p. 70-71.

${ }^{90}$ Alguns autores aludem a esse fenômeno como rerregulação. Sobre o tema, confira-se: MOREIRA, Vital. A Autorregulação Profissional e Administração Pública, 1997, p. 43.

${ }^{91}$ Curso de Direito Administrativo. 10 ed., 2014, p. 674.
} 
O consenso, portanto, visa a permitir o alcance mais efetivo e abrangente dos anseios a serem atingidos. Não apenas porque a decisão terá maior legitimidade e aplicabilidade, visto que o particular participou de sua construção, mas também porque permite que a Administração tenha contato com as peculiaridades concretas. Melhor explicando, o consenso visa a aproximar a autoridade decisória da realidade concreta, de modo que possa obter um conhecimento mais específico. Por vezes esse conhecimento só pode ser obtido mediante a participação dos particulares, que detém a expertise da questão a ser abordada ${ }^{92}$.

É dever de a Administração Pública buscar os melhores meios para a satisfação das suas atividades, mas nem por essa razão a atuação deverá ser impositiva. Afinal, a atuação estatal é instrumental e não fim em si mesmo. A participação da sociedade não pode ser vista como uma mitigação do interesse coletivo, pelo contrário, visa a maximizar a sua efetivação.

\subsection{A atuação impositiva como o “último” reduto}

Ao longo dos tópicos anteriores procurou se demonstrar como a introdução de métodos consensuais tem se mostrado relevante para a atuação administrativa. No entanto, essa opção não deve ser considerada como uma solução absoluta à atuação administrativa.

Reputa-se que o bom funcionamento da Administração Pública requer a conjugação de atividades impositivas e consensuais, em que ações impositivas e promocionais tendem a compor e mesclar as decisões administrativas. CARLOS ARI SUNDFELD muito bem destaca que: “(...) não se pode ignorar o caráter bipolar do direito administrativo, tomando um só polo como dogma e lançando o outro às feras ${ }^{93}$,, afinal "Os opostos convivem no direito administrativo 94 ". Desse modo, a atuação administrativa impositiva deve conviver com aquela dita consensual, de modo que se tornem limitadoras uma da outra.

Assim, podem se colocar como limites extremos à atuação administrativa os polos: impositivo e consensual, de modo que o Estado possa atuar tanto nesses polos como

\footnotetext{
${ }^{92}$ Nesse sentido, confira-se: "O elogio ao consenso cumpre o papel de fundamentar a consensualidade no Direito Administrativo. Assim, na medida em que as competências detidas pelo Poder Público podem ser satisfeitas de forma menos incisiva ao administrado, com menores custos e resultados mais efetivos, a administração por acordos passa a ser compreendida como legítima na Administração Pública" (PALMA, Juliana Bonacorsi de. Atuação administrativa consensual. Estudo dos acordos substitutivos no processo administrativo sancionador, 2010, p. 84).

${ }_{93}^{93}$ Direito Administrativo para Céticos, 2012, p. 92.

${ }^{94}$ SUNDFELD, Carlos Ari. Direito Administrativo para Céticos, 2012, p. 86.
} 
em zonas intermediárias. Isso permite uma modulação da atuação administrativa que se sobreponha a essa dicotomia, permitindo que sejam constituídas novas formas de relações ${ }^{95}$.

A atuação impositiva não é eliminada pela consensualidade, mas torna a sua aceitação mais eficaz, porque permite que os destinatários das normas de coerção ou repressão, como se prefira denominar, reconheçam com maior facilidade a legitimidade e validade de seus comandos ${ }^{96}$. Isso porque tendem a participar do processo de formulação ou decisão e, ainda que optem por não participar, possuem o direito potencial de influir na tomada de decisões.

Mas, por outro lado, como enfatiza ANA ROQUE a 'arte de consenso', considerada como toda a capacidade de construção concertada, "não pode dispensar o contributo da força jurídica, ao menos como último reduto ou até mero recurso potencial à disposição do organismo regulador ${ }^{97 ”,}$.

Nessa linha também enfatiza JULIANA BONACORSI DE PALMA:

"O fundamental para a garantia da funcionalidade tanto da atuação imperativa quanto da atuação consensual é a alternância entre elas. Sem a constante ameaça da imperatividade, que não se coloca pela previsão normativa de sanções gravosas, mas pela real aplicação de sanções simbólicas pela autoridade administrativa com o devido cumprimento, não há acordos administrativos eficazes. Sem a consensualidade, porém, a Administração Pública passa a andar na contramão da demanda por participação administrativa, colocando em questionamento a legitimidade de seu poder administrativo, além de negligenciar potencial mecanismo de eficácia da satisfação das finalidades públicas ${ }^{98,}$.

Desse modo a opção entre uma atuação impositiva ou consensual dependerá de qual modalidade (ou de qual composição entre essas modalidades) permitirá o melhor exercício das capacidades de o Estado em conseguir executar do melhor modo possível os

\footnotetext{
95 FLORIANO DE AZEVEDO MARQUES NETO diz: “A depender destas relações, se estabelecerão não dois polos claros e nitidamente separados, mas múltiplos polos de interesse, inter-relacionados $e$ determinantes de equilíbrios vários e cambiantes. Estas variadas relações demonstram que no polo dos indivíduos há diversas clivagens e diferentes interesses em face aos quais o polo da autoridade arbitrará e deferirá tratamentos legitimamente desuniformes" (A concessão como instituto do Direito Administrativo, 2013, p. 511).

${ }^{96}$ Como diz RAMÓN MARTÍN MATEO: “A Administração não pode funcionar eficazmente se não encontra um apoio colaborador e complementar dos próprios destinatários das medidas” (Manual de Derecho Administrativo. 25. ed., 2006, p.57).

${ }^{97}$ Regulação do Mercado. Novas tendências, 2004, p. 22.

98 PALMA, Juliana Bonacorsi de. Atuação administrativa consensual. Estudo dos acordos substitutivos no processo administrativo sancionador, 2010, p. 99.
} 
objetivos a que se propõe. A legitimidade estatal será tanto maior quanto maior for a coerência e a adstrição da normatização ou de suas condutas em relação aos problemas que pretende regular ${ }^{99}$,

\subsection{Mecanismos de consenso existentes no direito brasileiro: a logística reversa}

Há algumas figuras jurídicas que são bastante permeáveis à consensualidade, tais como: processo administrativo, acordos substitutivos em processo administrativo sancionador ${ }^{100}$, contrato administrativo ${ }^{101}$, especialmente os contrato de concessões (incluídas as concessões comuns e as parcerias-público privadas) ${ }^{102}$ e arbitragem. Na seara ambiental pode-se referir ao processo de licenciamento ambiental ${ }^{103}$ e, mais recentemente, à logística reversa ${ }^{104}$.

O presente trabalho tem por objetivo analisar a figura da logística reversa e, a partir dela indicar características que permitam uma maior interação entre a Administração Pública, agentes econômicos e cidadãos, de modo a demonstrar possibilidades de desenvolvimento da consensualidade na formação da decisão administrativa.

A logística reversa é imposta aos fabricantes, os distribuidores, os comerciantes e os importadores de determinados setores, como de pneumáticos, embalagens de óleo lubrificante, lâmpadas fluorescentes, de vapor de sódio, mercúrio e luz mista, eletroeletrônicos, pilhas e baterias, agrotóxicos ${ }^{105}$. Essa obrigatoriedade possui um viés impositivo. No entanto, abriu-se espaço para a negociação e para o debate sobre o modo de operacionalização das atividades e da implantação de infraestruturas necessárias para o desenvolvimento das atividades de logística reversa.

A consensualidade pode se manifestar tanto pela utilização de acordos setoriais, termos de compromisso como pela participação da sociedade na formulação dos planos

\footnotetext{
${ }^{99}$ Regulação do Mercado. Novas tendências, 2004, p. 28.

100 Sobre o tema confira-se: PALMA, Juliana Bonacorsi de. Atuação administrativa consensual. Estudo dos acordos substitutivos no processo administrativo sancionador, 2010.

101 Confira-se nessa linha: MENEZES DE ALMEIDA, Fernando. Contrato administrativo, 2012 e MONTEIRO, Vera. Concessão, 2010.

102 A respeito deste tema confira-se a tese de titularidade de FLORIANO DE AZEVEDO MARQUES NETO: A concessão como instituto do Direito Administrativo, 2013.

${ }^{103}$ Nessa linha, confira-se: SUNDFELD, Carlos Ari. Direito Administrativo para céticos, 2012, p. 91.

104 Em apertada síntese, a logística é um instrumento que permite a reinserção de resíduos na cadeia produtiva, mediante algum processo de tratamento, como a reciclagem, ou ainda por meio de reuso. Além disso, a logística também é um mecanismo que visa à prevenção de resíduos em razão (i) da adoção de novas tecnologias e estratégias operacionais por parte das empresas, assim como pela (ii) educação ambiental dos cidadãos. Para maiores informações sobre o conceito de logística reversa, consulte-se o capítulo 3.

105 Mas esse instrumento também pode ser praticado em outros setores, sendo possível que as empresas adotem voluntariamente estratégias de gestão de resíduos.
} 
nacionais, estaduais e municipais de gerenciamento de resíduos sólidos. Além disso, ela pode ser empregada para estimular novos padrões de comportamento, que sejam mais sustentáveis.

A repartição de obrigações e deveres jurídicos (a denominada "responsabilidade compartilhada”) também pode ser objeto de consensualidade. Pense-se no caso de produtos que não possuem origem do produtor, fabricante ou importador identificável, os ditos produtos “órfãos”, a quem competirá a responsabilidade pela gestão do resíduo? A resposta a essa questão dependerá de uma composição de interesses, visto que não há exigência legal de que esse custo seja absorvível pelas empresas. Ademais, a obrigação pela gestão dos resíduos tende a ser imposta aos agentes econômicos na medida daquilo que produzem.

Há também outras formas consensuais que podem ser utilizadas para a gestão de resíduos, como as parcerias-público privadas.

O estímulo à redução do consumo, que também é uma exigência prevista em lei, impõe a reformulação do modo produtivo (ou, quando menos, de sua operacionalização), o que impacta diretamente nas atividades econômicas ${ }^{106}$. Isso envolve novas estratégias de composição de interesses em relação às exigências a serem impostas. E como o cumprimento dessas metas de logística reversa pode envolver custos vultosos, torna-se ideal que haja composição de interesses na formulação das estratégias de modelação da logística reversa. Afinal de nada adianta um sistema de logística reversa ideal no plano teórico, mas que não possui uma operacionalização factível.

A participação das empresas torna-se imprescindível, para que se possa dimensionar de modo mais completo a estrutura que ser dará à logística reversa.

Os cidadãos também participam da implementação da logística reversa. A coleta seletiva, por exemplo, é uma das etapas iniciais de retorno dos resíduos. Mas se não houver uma separação prévia adequada, poderá comprometer-se a qualidade dos resíduos e consequentemente reduzir-se a quantidade de material reciclado ou reutilizado, por exemplo.

A divisão dos custos das políticas públicas, como aquelas de cunho ambiental, passa a exigir uma atuação conjunta de todos os interessados, de modo que se possibilite o atingimento dos melhores resultados em relação às ações desejadas. Essa atuação em cooperação é resultado de uma relação que tenta estruturar o Estado e os particulares em

\footnotetext{
${ }^{106}$ Mesmo que as empresas optem pela terceirização das atividades de logística reversa haverá, de algum modo, alteração na organização produtiva, nem que seja para se reduzir custos.
} 
relação de maior horizontalidade, de modo a reduzir, em algumas situações, uma predominância de resultados unilaterais e não cooperados ou consensuais ${ }^{107}$.

${ }^{107}$ DERANI, Cristiane. Direito Ambiental Econômico, 1997, p. 157-158. 


\section{CAPÍTULO 2 - GESTÃO AMBIENTAL SUSTENTÁVEL E DESENVOLVIMENTO SOCIOECONÔMICO}

\subsection{Direito fundamental ao meio ambiente equilibrado e ao desenvolvimento sustentável}

Há diversos elementos que compõem o meio ambiente, como a água, o ar, o solo, a flora, a fauna e o homem ${ }^{108}$, de modo que o meio ambiente não é constituído apenas por recursos naturais, mas por todos os elementos que o compõem, sem que se possa dissociá$\operatorname{los}^{109}$. Como esses elementos estão relacionados entre si, não é possível que produzam efeitos de modo isolado. Então, as múltiplas interações que se realizam entre esses elementos, algumas de caráter natural e outras provocadas por ações antrópicas, geram efeitos em todo o meio ambiente.

As ações humanas tendem a apresentar um potencial de degradação ambiental bastante elevado, que pode causar distorções no funcionamento adequado do ecossistema. Essas distorções, em alguns casos, nem sempre são vitais à manutenção da qualidade de vida da existência humana, pelo contrário, em alguns casos, podem até comprometer essa existência. Por isso, muitos impactos ambientais necessitam ser mitigados, mantendo-se uma relação o mais harmônica possível entre todos os elementos do meio ambiente ${ }^{110}$.

O bem-estar humano exige qualidades mínimas do ar, quantidades suficientes de água potável, solos adequados para se manter a flora e a fauna nativas e também áreas para o cultivo de alimentos, produção de energia, combustíveis fosseis, dentre outros fatores.

A CF/88 prevê no art. 225 a proteção do meio ambiente como um direito fundamental essencial à qualidade de vida ${ }^{111}$ : “Todos têm direito ao meio ambiente ecologicamente equilibrado, bem de uso comum do povo e essencial à sadia qualidade de vida, impondo-se ao Poder Público e à coletividade o dever de defendê-lo e preservá-lo

\footnotetext{
${ }^{108}$ Como destaca FLORIANO DE AZEVEDO MARQUES NETO o meio ambiente é “composto pelos recursos naturais (bens dominialmente públicos), pelas propriedades urbanas e rurais (públicas e privadas), pelos animais (criações privadas, animais selvagens na fauna, públicos), pelos automóveis, máquinas, bens de produção, as próprias pessoas naturais. O meio ambiente... é o universo em que nos inserimos, inclusive para além das fronteiras geopolíticas”. (Bens públicos: função social e exploração econômica: o regime das utilidades públicas, 2009, p. 96).

109 ÉDIS MILARÉ destaca que o Patrimônio Ambiental é tripartido e contempla não apenas recursos naturais, mas também bens artificiais e culturais. (Direito do ambiente. 8. ed., 2013, p. 510).

${ }^{110}$ DE VINCENTIIS, Giuseppantonio, La evolución del concepto de desarrollo sostenible, 2012.

${ }^{111}$ Aqui vale lembrar que os direitos fundamentais, como ensina MARÇAL JUSTEN FILHO, não se tornam fundamentais porque estão positivados no texto constitucional, mas porque são essenciais a tutela da dignidade da pessoa humana. No caso dos direitos ambientais isso fica evidente, porque a vida humana depende diretamente do meio ambiente (Curso de Direito Administrativo. 10. ed., 2014, p. 177).
} 
para as presentes e futuras gerações”. Ou seja, é uma noção de proteção ambiental que exige um equilíbrio entre diversos aspectos que compõe o meio ambiente. Desse modo os aspectos social, ambiental e até mesmo econômico ${ }^{112}$ devem ser compatibilizados.

A noção positivada na CF/88 não afasta por completo a possibilidade de degradação do meio ambiente, mas impõe um modelo de proteção ambiental que possibilite a continuidade da existência humana e a manutenção do meio ambiente. Como aduz ÉDIS MILARÉ, o direito ao meio ambiente é uma "extensão do direito à vida, quer sob o enfoque da própria existência física e saúde dos seres humanos, quer quanto ao aspecto da dignidade dessa existência - a qualidade de vida ${ }^{113, "}$.

Então, em alguma medida poderá haver a exploração ambiental, mas a utilização de recursos naturais não pode ser desmedida a ponto de esgotá-los e eliminar a qualidade de vida ou até mesmo a própria existência humana, existência esta atual ou futura. Isso não torna a questão ambiental secundária ${ }^{114}$, mas é um indicativo de que a obtenção de avanços sociais e econômicos não pode se dar de modo descolado à proteção do meio ambiente.

A fruição dos recursos naturais exige um planejamento em longo prazo. Inclusive porque o direito ao meio ambiente equilibrado é um direito fundamental que pertence a toda coletividade e transcende a sua aplicabilidade inclusive àqueles que ainda sequer existem (“futuras gerações”) para lhes garantir condições adequadas de vida ${ }^{115}$.

A proteção ambiental está associada também ao direito fundamental ao desenvolvimento sustentável. A concepção incorporada pela CF/88 é a mesma prevista no Relatório Brundtland - documento que tornou mundialmente conhecida a noção de “desenvolvimento sustentável”116.

\footnotetext{
${ }^{112} \mathrm{O}$ modo de produção econômico se associa a existência humana e depende diretamente dos recursos naturais.

${ }^{113}$ Direito do Ambiente. 8. ed., 2013, p. 258.

${ }^{114}$ Essa visão até certo tempo não era prevalente. Havia um entendimento de que o crescimento econômico não poderia ser afetado em questões centrais por demandas de cunho ambiental. $\mathrm{O}$ aspecto econômico era considerado como preponderante, mas, no âmbito brasileiro, com a promulgação da CF/88 e depois com a alteração do art. 170, essa situação passou a ser mitigada. Nos dizeres de CRISTIANE DERANI: "Tal obstinação na pregação da concepção de crescimento fez dele um mecanismo que se tornou totalitário, dogmático, sendo grandemente responsável pelo constante fracasso da aplicação de uma política ambiental toda vez que atinge, ou procura atingir, algum ponto central de posições socioeconômicas" (Direito Ambiental Econômico, 1999, p. 87).

${ }^{115}$ ÉDIS MILARÉ menciona que é muito comum se diferenciar a cooperação entre gerações como sincrônica (no caso de as gerações serem presentes) e diacrônica (aquela que se refere a geração futura), mas propõe o termo solidariedade intergeracional, porque reputa melhor traduzir os vínculos solidários entre as gerações presentes e futuras. (Direito do Ambiente. 8. ed., 2013, p. 259).

${ }^{116}$ GIUSEPPANTONIO DE VICENTIIS enfatiza que o termo desenvolvimento sustentável teve a primeira aparição num documento oficial firmado entre países africanos, em 1969, para a conservação da natureza, embora o autor enfatize que desde textos anteriores, como de THOMAS MALTHUS e MARIE JEAN
} 
A CF/88 prevê ainda a defesa do meio ambiente ${ }^{117}$ como um dos princípios gerais que regem a atividade econômica. É possível inclusive atribuir-se um tratamento diferenciado às atividades econômicas, a depender dos impactos ambientais que possam provocar (art. 170, inc. VI).

O aspecto econômico não pode se sobrepor ao aspecto ambiental, afinal ambos são alçados à condição de direitos fundamentais ${ }^{118}$. Mas é inegável que a noção de desenvolvimento econômico se torna cada vez mais dependente da sustentabilidade ambiental. Ou seja, para se manter um nível de qualidade de vida e de conforto, tal como se concebe hoje, é necessário haver maior proteção ambiental. É inviável se pensar em um desenvolvimento econômico sustentável sem a modificação da estruturação do modelo econômico atual.

\title{
2.1.1 A compatibilização dos interesses ambientais e socioeconômicos
}

Como visto as relações entre a sociedade e a natureza não podem ser dissociadas, pois as atividades econômicas e a própria existência humana dependem do meio ambiente. Como destaca CRISTIANE DERANI:

\begin{abstract}
"Uma vez compreendido que recurso natural é base da produção social, independentemente do lugar que ocupa no processo produtivo, a modificação do conjunto destes recursos, bem como de sua forma de apreensão e trabalho na sociedade, atinge toda esfera da sociedade. Isto posto, a proteção dos recursos naturais e do meio ambiente passa a ser empreendida dentro de um sentimento de solidariedade insofismável ${ }^{119 »,}$.
\end{abstract}

Logo, a efetivação do direito fundamental ao meio ambiente equilibrado exige a compatibilização entre as necessidades humanas e o meio ambiente.

O debate em torno dessa noção de equilíbrio entre meio ambiente e sociedade é bastante complexo e pode se reputar que uma das grandes questões que se coloca é a

ANTOINE CONDORCET, tenha se discutido sobre o futuro da existência humana e as condições ambientais. (La evolución del concepto de desarrollo sostenible).

${ }^{117}$ Esse princípio foi incluído pela Emenda Constitucional 42/2003, ou seja, inicialmente o meio ambiente não exercia pressão e competição com aqueles provenientes das esferas econômica e social. Isso demonstra o aprofundamento e a relevância que o tema teve ao longo das últimas décadas. A valorização do meio ambiente tornou-se um elemento essencial para o desenvolvimento econômico, social e para a qualidade de vida da população.

${ }^{118}$ Há quem atribua ao meio ambiente um valor “supremo”, no entanto, não se pode dizer que a Constituição de 1988 assim tenha definido, porque os direitos fundamentais coexistem, não há aprioristicamente um direito fundamental que se sobreponha aos outros. Em sentido contrário, confira-se: MILARÉ, Édis. Direito do Ambiente. 8. ed., 2013, p. 257.

119 Direito Ambiental Econômico, 1997, p. 260. 
delimitação do que venha a ser uma relação equilibrada. Isso porque essa valoração de “equilíbrio” se modifica a depender dos aspectos culturais, sociais, políticos e econômicos.

Não existe uma homogeneidade no tocante aos padrões de produção, de consumo e do que seja a qualidade de vida. Não existe um único modo de vida adequado. Há diversas formas de se desenvolver as interações socioeconômicas e ambientais. Um exemplo disso são os movimentos de contracultura dos anos sessenta, como o movimento hippie, que pregavam uma modificação dos padrões sociais, econômicos, políticos e culturais.

A noção de qualidade de vida para o movimento hippie é diferenciada em relação a outras estruturações sociais, visto que para essa concepção de vida não há, por exemplo, uma ordem econômica capitalista, não há necessidade de se incentivar o consumo, rejeitase a industrialização, incentiva-se um modo de vida comunitário, a produção agrícola de modo artesanal, dentre outros aspectos. A própria noção da infraestrutura necessária para o desenvolvimento das atividades humanas é distinta, assim como o padrão de desenvolvimento tecnológico. Isso envolve uma determinada concepção cultural e política que refletem padrões sociais e econômicos diferenciados, permitindo uma relação também distinta com o meio ambiente.

A satisfação do direito fundamental ao meio ambiente perpassa, em primeiro lugar, pela identificação do modelo de sociedade que se pretende efetivar, quais padrões de qualidade de vida e quais modos de produção econômica que se pretende implementar ${ }^{120}$. A escolha do modelo econômico, social ou cultural depende nitidamente de critérios ideológicos, que não podem ser cientificamente apurados. Os estudos científicos não podem determinar qual o melhor sistema econômico, político, social e cultural, mas podem balizar a escolha de determinados critérios produtivos, que impactem menos o meio ambiente e que reduzam desigualdades sociais ${ }^{121}$.

\footnotetext{
${ }^{120}$ A escolha do modelo político e econômico influencia a relação que se tem com o meio ambiente. LOUIS ALTHUSSER utiliza uma metáfora para explicar a estrutura social e a forma como o modo de produção capitalista influencia as demais esferas: "Qualquer pessoa pode compreender facilmente (...) toda a sociedade como um edifício que comporta uma base (infraestrutura) sobre a qual se erguem os dois $<<$ andares $>>$ da superestrutura (...). Podemos dizer que os andares da superestrutura não são determinantes em última instância, mas que são determinados pela base". Para esse autor o modo de produção capitalista determina todas as demais relações. (Ideologia e aparelhos ideológicos do Estado. 3. ed., 1980, p. 26-27).

${ }^{121}$ Mas com isso não se ignora que muitas práticas apenas em longo prazo possibilitam a aferição de que sejam danosas ou não. Essa identificação de quais condutas são ou não danosas muitas vezes depende da tecnologia disponível.
} 


\subsubsection{A necessidade de reformulação do modelo econômico}

Há inúmeros problemas de poluição ambiental que têm afetado seriamente a qualidade de vida. Pense-se no caso da emissão de poluentes, escassez de energia, o aumento vertiginoso de resíduos sólidos. Várias medidas têm sido impostas para que se possa mitigar essa incompatibilidade com o meio ambiente ${ }^{122}$, como, por exemplo: a imposição de normas ambientais mais rigorosas na emissão de poluentes, o desenvolvimento de tecnologias que consumam menos energia, métodos de produção que exijam menos matérias-primas e a própria gestão de resíduos sólidos. Mas ainda hoje não há uma definição de que padrão econômico é o mais adequado: há apenas o indicativo, muito claro, de que o sistema atual necessita de reformulações profundas. Se há, por exemplo, altos índices de consumo, então, é preciso haver, quando menos, uma contrapartida, como um programa que envolva a gestão dos resíduos produzidos.

Os problemas ambientais não impõem a ausência de desenvolvimento econômico. Mas exigem novas estratégias que obstaculizem um "colapso ambiental e de esgotamento dos recursos naturais" ${ }^{223}$. Assim, surge a necessidade de se repensar as condições sociais, políticas, econômicas e tecnológicas para se verificar como podem ser traçadas metas para um desenvolvimento sustentável.

A explicação de STUART L. HART de que o capitalismo global está numa “encruzilhada" é bastante exemplificativa da necessidade de mudança do modo de organização econômica ${ }^{124}$. O autor enfatiza que o capitalismo é colocado em xeque e a solução para a sua sobrevivência é tornar-se mais inclusivo, de modo que interesses anteriormente ignorados tornem-se uma preocupação do setor empresarial. Nesse sentido a concepção de desenvolvimento sustentável é alçada a condição de uma nova estratégia para os negócios, os ditos negócios sustentáveis ${ }^{125}$. Com isso impõem-se novas modulações empresariais que observem aquela margem da sociedade que era

\footnotetext{
${ }^{122}$ A regulação em matéria ambiental tem se tornado mais rigorosa e isso tem possibilitado a redução de muitos problemas ambientais, principalmente nos países mais desenvolvidos.

${ }^{123}$ ZANETI, Izabel Cristina Bruno Bacellar. Educação ambiental, resíduos sólidos urbanos e sustentabilidade. Um estudo de caso sobre o sistema de gestão de Porto Alegre/RS, 2003, p. 33.

${ }^{124} \mathbf{O}$ capitalismo na encruzilhada. As inúmeras oportunidades de negócios na solução dos problemas mais difíceis do mundo, 2006, p. XXVI.

${ }^{125}$ STUART L. HART apresenta alguns exemplos de negócios sustentáveis como o da subsidiária indiana da Unilever (Hindustan Lever Limited - HLL) que se vale da compra de matérias-primas de produtores locais e ainda estimula o desenvolvimento de produtos específicos para as populações de baixa renda. Os funcionários da empresa têm de passar um período em vilas rurais para obter informações e preferências dos consumidores, as quais serão utilizadas no desenvolvimento de produtos. Desse modo a empresa conseguiu expandir seus negócios a camadas antes não atingidas, aumentando a sua lucratividade, o número de empregos e as condições de higiene da população. (O capitalismo na encruzilhada. As inúmeras oportunidades de negócios na solução dos problemas mais difíceis do mundo, 2006, p. 49-50).
} 
tradicionalmente ignorada, respeitando-se não apenas a vida humana, mas também das demais espécies e a natureza como um todo ${ }^{126}$.

\subsubsection{O problema da definição de desenvolvimento sustentável}

O desenvolvimento sustentável é tido como o mecanismo chave para melhorar distorções entre métodos e instrumentos produtivos, degradação ambiental e mazelas sociais. Para tanto, é necessária a efetivação de políticas públicas que optem por equilibrar três aspectos: econômico, ambiental e social. Essa ressalva é prevalente porque, em princípio, parece intuitivo se definir o que venha a ser a sustentabilidade.

A primeira concepção que costuma se atribuir ao termo sustentável seria de proteção ambiental. No entanto, essa é apenas uma das facetas desse conceito. É preciso alertar acerca da necessidade de se tentar compreender esse conceito de forma técnica. O que, desde já, adverte-se não é tarefa simples. Primeiro porque o termo “sustentável” é um termo vago e impreciso. Na doutrina, seja jurídica ou não, é difícil constatar uma definição exata do termo. Segundo porque é um conceito que exige uma reflexão profunda sobre o modo de produção, de consumo e até mesmo de qualidade de vida das populações ${ }^{127}$. Poder-se-ia até aludir a sustentabilidade como um novo modelo de estruturação estatal, econômica, social e cultural.

JOSÉ ELI DA VEIGA compreende que a sustentabilidade é um conceito que não diz respeito exclusivamente à proteção ambiental, mas sim à esperança do homem de que seja possível compatibilizar a expansão de suas liberdades com a conservação dos ecossistemas que constituem sua base material ${ }^{128}$.

Nesse sentido, é preciso entender que o atingimento do desenvolvimento sustentável não implica meramente preservar os recursos naturais, mas sim preservá-los e concomitantemente buscar o atingimento de novas tecnologias, que permitam a redução da poluição, a redução da quantidade de matérias-primas e de recursos não renováveis no processo produtivo, o crescimento das economias ${ }^{129}$ e a satisfação das necessidades

\footnotetext{
${ }^{126}$ HART, Stuart L. O capitalismo na encruzilhada. As inúmeras oportunidades de negócios na solução dos problemas mais difíceis do mundo, 2006, p. XXVI.

127 Sobre a questão do crescimento econômico há opinião em sentido contrário, como a de SERGE LATOUCHE defensor da tese do “decrescimento sustentável”. Esse economista e filósofo francês considera que o desenvolvimento é insustentável, porque não há possibilidade lógica de se compatibilizar, em longo prazo, um modelo de consumo ilimitado em um planeta com recursos limitados. Sobre o tema confira-se a obra: Pequeno tratado do decrescimento sereno, 2009.

${ }^{128}$ Sustentabilidade. A legitimação de um novo valor, 2010, p. 39.

${ }^{129}$ Como destaca MARCOS NOBRE: “(...) temos de entender o conceito de 'desenvolvimento sustentável' não como uma reformulação dos termos em que se colocava a questão ambiental na década de 1970, mas
} 
sociais. Afinal, o desenvolvimento sustentável possui interfaces econômicas, ecológicas e sociais, que devem ser compatibilizadas ${ }^{130}$.

A sustentabilidade do meio ambiente é entendida como a capacidade de manter a qualidade e a existência dos recursos naturais. É muito importante reconhecer que as atividades humanas estão sujeitas a limitações. Em alguns casos será inviável aceitar a ocorrência de danos para o desenvolvimento de determinadas atividades, como nos casos em que dano puder ser (ou o risco de dano indicar ser) irreversível ou de difícil reparação, mas não é todo impacto ambiental que obstaculiza o desenvolvimento econômico ${ }^{131-132}$.

A sustentabilidade social envolve a capacidade de garantir a satisfação de direitos básicos, condições de bem-estar social, como saúde, educação, moradia digna, alimentação adequada, acesso à água potável e maior igualdade na distribuição de recursos ${ }^{133}$. JUAREZ FREITAS acrescenta ainda o incremento da equidade intergeracional e o engajamento na questão do desenvolvimento sustentável ${ }^{134}$.

O desenvolvimento dito sustentável requer, portanto, a participação de todas as esferas, seja o Estado, cidadãos ou o setor empresarial. A atuação do Estado é importante na formulação de políticas públicas, da regulação e da fiscalização de ações sustentáveis. Os cidadãos devem atuar ativamente na formação da tomada de decisão em matéria ambiental ou socioeconômica para garantir uma democracia mais efetiva ${ }^{135}$.

como uma resposta precisa àquela questão, vale dizer: desenvolvimento (no sentido decrescimento econômico') e meio ambiente... não são contraditórios” (Desenvolvimento sustentável: a institucionalização de um conceito, 2002, p. 42).

${ }^{130}$ Nessa linha confira-se: CÉSPEDES, Carlos Bolaños, Desarrollo sostenible: un nuevo paradigma para la humanidad, 2002, p. 295.

${ }^{131}$ DE VINCENTIIS, Giuseppantonio, La evolución del concepto de desarrollo sostenible, 2012.

132 Para ilustrar essa linha de raciocínio pode-se citar uma a disputa julgada pela Corte Internacional de Justiça, que ficou conhecida como "o caso das papeleras”. O impasse decorreu da instalação de duas indústrias de produção de pasta de celulose no rio Uruguai. Para a Argentina a construção dessas indústrias feria o acordo de cooperação ambiental, que havia sido celebrado por esses dois países para a proteção desse rio de possíveis e irreversíveis danos ambientais. A decisão final sobre o caso foi no sentido de possibilidade de instalação das indústrias, sobretudo diante dos investimentos a serem realizados no Uruguai, que foram avaliados em torno de 1,8 bilhões de dólares. Entendeu-se que não restou demonstrado dano ambiental, sendo possível compatibilizar o desenvolvimento econômico da região com a preservação ambiental. Para isso foi procedida à imposição de que sejam adotadas medidas para evitar eventuais danos ambientais. Sobre o assunto, confira-se: CORRÊA, Ceres Fernanda; GOMES, Eduardo Biacchi, O direito fundamental ao desenvolvimento sustentável: uma análise a partir do caso das papeleras, 2011 e NOSCHANG, Patrícia Grazziotin, O Caso das Papeleras na Corte Internacional de Justiça - Direito Ambiental versus Direito Econômico?, 2008. Disponível em: http://publicacoes.unigranrio.edu.br/index.php/rdugr/ article/viewFile/201/200. Acesso em 12.07.2014.

${ }^{133}$ DE VINCENTIIS, Giuseppantonio, La evolución del concepto de desarrollo sostenible, 2012.

${ }^{134}$ Sustentabilidade. Direito ao Futuro. 2. ed., 2012, p. 60.

${ }^{135}$ A respeito do processo de tomada de decisão das agências reguladoras ensina DIOGO DE FIGUEIREDO MOREIRA NETO: “(...) o núcleo juspolítico da administração reguladora está indisputadamente na democratização do processo de tomada de decisão administrativa a ser adotado nos setores econômicos $e$ sociais em que a politização da decisão carece de sentido e em que, distintamente, a consensualidade produz 
As empresas também podem ter um papel crucial na melhoria de vida das pessoas e na proteção do meio ambiente, mediante o desenvolvimento de novas tecnologias e modelos produtivos mais eficientes e menos poluentes.

No atual estágio de desenvolvimento econômico deve se pensar em uma reformulação das estruturas econômicas, mas sem uma implementação radical, pois isso inviabilizaria a aplicação prática e colocaria em xeque não apenas o modo de produção econômica, mas também a qualidade de vida e o conforto proporcionado pelos recentes avanços tecnológicos, a que grande parte da sociedade não está disposta a abrir mão. A necessidade de mudança é premente, mas exige estudos, cautela e razoabilidade na aplicação prática, sob pena de virar um discurso retórico.

De todo modo, com isso não se defende a manutenção de um quadro de utilização desmedida de recursos naturais, mas sim se chama atenção à ponderação de interesses envolvidos. A noção de sustentabilidade precisa ser pensada a partir do cotejo entre os instrumentos de preservação do meio ambiente e desenvolvimento econômico e social ${ }^{136-}$ 137, embora possam existir posições que o relacionem com maior proximidade de uma ou de outra perspectiva.

Assim, o princípio da sustentabilidade pode ser entendido como um princípio norteador, que estabelece um parâmetro ideal a ser atingido ou ainda, sob um viés mais estrito, seria um princípio vinculativo no sentido de que exige política econômicas e sociais efetivas para sua implementação ${ }^{138}$.

\subsection{A gestão de resíduos sólidos como objeto das pautas políticas}

O sistema econômico por muito tempo ignorou as questões ambientais, como as consequências da utilização desmedida dos recursos naturais, a ausência ou deficiência na gestão de resíduos sólidos. Não havia uma preocupação com desperdícios e muito menos com a preservação em longo prazo. Com a evolução do sistema tecnológico, aumento do

resultados mais céleres, mais justos e menos onerosos”. O entendimento defendido pelo autor é a propósito da análise das agências reguladoras, mas pode ser aplicado para qualquer processo decisório do Estado (Direito Regulatório, 2003, p. 178).

${ }^{136}$ NUSDEO, Ana Maria. Pagamento por serviços ambientais: sustentabilidade e disciplina jurídica, 2012, p. 136.

137 JUAREZ FREITAS destaca: “A sustentabilidade precisa (...) ser assimilada em sua complexidade poliédrica. Não pode ser vítima dos enfoques banalizantes e dos reducionismos extremos". (Sustentabilidade. Direito ao Futuro, 2. ed., 2012, p. 55).

${ }^{138}$ CIPRIANO, Tasso A. Richetti Pires. O conceito econômico-jurídico de desenvolvimento sustentável, 2011, p. 360-377. 
consumo, começou a se discutir a escassez de recursos naturais e a questão ambiental ganhou destaque.

Os grandes movimentos ambientalistas surgiram já na década de $70^{139}$ e foram os responsáveis, em grande medida, por estimular importantes discussões sobre os rumos da produção industrial, a necessidade de redução do consumo, a alocação dos recursos de modo mais eficiente e a redução dos impactos provocados na natureza.

Desde a década de 70, também têm sido realizadas conferências mundiais que, dentre outras temáticas, abordam a compatibilização entre meio ambiente e desenvolvimento sustentável, como: a Conferência de Founex, realizada na Suíça, em 1971, a Conferência das Nações Unidas sobre Meio Ambiente Humano, realizada em Estocolmo, em 1972, a Conferência das Nações Unidas sobre Desenvolvimento Sustentável, realizada no Rio de Janeiro, em 1992 (a conhecida ECO 92), a Cúpula Mundial sobre Desenvolvimento Sustentável, realizada em Johanesburgo, em 2002, a Conferência de Copenhague, realizada na Dinamarca, em 2009 e a RIO + 20, realizada no Rio de Janeiro, em 2012.

O debate sobre o reaproveitamento dos resíduos insere-se no contexto de crescente necessidade de compatibilização entre preservação do meio ambiente e adequado desenvolvimento das atividades econômicas. Isso porque muitos dos produtos, matérias e bens que são consumidos podem ser reinseridos na cadeia produtiva, o que gera a redução do consumo de matérias-primas, a preservação de recursos naturais e a redução dos custos de produção. Além disso, também há redução de materiais que precisarão ser realocados em lixões ou em aterros, que se tornam cada vez mais limitados e escassos.

\subsection{A problemática do descarte de resíduos sólidos urbanos}

Nas últimas décadas, ganhou destaque a preocupação com o destino dos resíduos sólidos descartados. Iniciaram-se diversas discussões no tocante a possibilidade de tratamento e disposição final dos resíduos. Com o tempo passou a se discutir inclusive sobre a necessidade de se estabelecer uma gestão adequada de toda a cadeia produtiva, incluindo-se nesse processo a fase final de descarte dos bens e produtos.

\footnotetext{
139 Pode-se citar grupos como Greenpeace e Friends of Earth, que são alguns dos maiores movimentos ambientalistas, que surgiram na década de 70.
} 
Até os dias atuais ainda se verificam diversas deficiências na gestão de resíduos $^{140}$, de modo que grande parte dos resíduos ainda não recebe o devido tratamento, sendo indevidamente desperdiçada, ao invés de se possibilitar o reaproveitamento ou a reinserção na cadeia produtiva. Tal situação ocasiona acúmulo dos resíduos de forma desorganizada, além de poder gerar a contaminação dos solos, das águas e a proliferação de doenças.

Há uma necessidade premente de modificação das condutas relativas ao manejo de resíduos, de modo que se potencialize a organização e o planejamento de políticas de coleta, o reaproveitamento e a reinserção de produtos e bens que foram consumidos no ciclo produtivo. Assim como, para evitar a poluição do solo, a contaminação de mananciais e o aumento da inutilização de grandes áreas para construção de aterros, mediante a redução da produção de rejeitos.

A ausência de tratamento e destinação final adequados torna-se ainda mais preocupante em relação a resíduos como grau de nocividade elevado, pois a eliminação deles requer tratamentos bem específicos. Em alguns casos, é necessário que esses resíduos sejam transformados em resíduos menos nocivos para então se efetuar a disposição final ${ }^{141}$.

O acidente ocorrido, em 1987, na cidade de Goiânia, com o Césio-137 é um exemplo de grave contaminação ambiental que de decorreu do descarte inadequado de resíduos radioativos ${ }^{142-143}$. Um aparelho de radioterapia foi abandonado e catadores de papel o identificaram como fonte de obtenção de sucata. Para obter-se a sucata é necessário

\footnotetext{
${ }^{140}$ Essa dificuldade na gestão de resíduos pode ser maior ou menor a depender de cada localidade, do nível de desenvolvimento econômico e social e das peculiaridades de cada tipo de resíduo, dentre outros fatores.

${ }^{141}$ Nesse sentido NICHOLAS GEORGESCU-ROEGEN explica: "Outros resíduos só têm a possibilidade de ser eliminados se forem transformados em resíduos menos nocivos graças a determinados tratamentos efetuados por nós, como quando, por meio de uma combustão melhorada,uma parte do óxido de carbono é transformada em gás carbônico e em calor. Para dar outro exemplo, uma grande parte da poluição pelo anidrido sulfuroso pode ser evitada mediante algumas instalações especiais. Porém, não é possível desfazernos de todos os resíduos dessa maneira. Temos um exemplo atual disso com a impossibilidade de reduzir a altíssima periculosidade da radioatividade dos resíduos nucleares." (O Decrescimento. Entropia, Ecologia, Economia, 2012, p. 92).

${ }^{142}$ O presente trabalho não irá abordar os resíduos radioativos, que estão sujeitos à legislação especial, mas trata-se do acidente com o Césio-137 porque é um dos casos mais representativos do descarte inadequado de resíduos.

${ }^{143}$ Esse acidente foi objeto de análise pelo STJ no julgamento do REsp 1.180.888 (GO), de relatoria do Min. Herman Benjamin ( j. 17.06.2010, DJ 28.02.2012). Nessa oportunidade o tribunal assentou que, nos termos do Decreto 81.394/1975, caberia à União ter desenvolvido programas de inspeção sanitária dos equipamentos, o que teria possibilitado a retirada da cápsula de Césio-137 antes do descarte do aparelho de radioterapia no qual estava inserida. Entendeu-se pela responsabilização objetiva e solidária da União e do Estado de Goiás pela ausência de fiscalização sanitário-ambiental da atividade nuclear e radioativa. No entanto, não se adentrou na discussão do descarte inadequado de resíduos, o que para a época do acidente ainda era uma questão pouco debatida. Desse modo, a questão discutida no referido julgado centrou-se na análise de responsabilização da União e do Estado. Mas o tema também é relevante também em matéria de gestão de resíduos.
} 
efetuar a desmontagem dos equipamentos e nesse processo de desmontagem houve a contaminação com o material radioativo tanto das pessoas que o manipularam como daquelas que adquiriram as sucatas, as quais inclusive se dispersaram por diversos lugares.

A cor azul e brilhante fez com que o material radioativo chegasse inclusive a ser levado para as residências. Além da contaminação de centenas de pessoas, animais, solo, água ainda houve a geração de uma quantidade bastante significativa de rejeitos, porque todo o material contaminado teve de ser descartado. Segundo informações da Secretaria de Saúde do Estado de Goiás foram gerados $3.500 \mathrm{~m}^{3}$ de rejeitos radioativos ${ }^{144}$. Desse modo, fica evidente que uma gestão inadequada dos resíduos e a ausência de fiscalização pelos responsáveis podem provocar impactos ambientais gravíssimos.

\subsubsection{Diferenciação entre resíduos e rejeitos}

Os resíduos podem ser reinseridos, de algum modo, na cadeia produtiva, seja por meio de reuso, remanufatura, reciclagem ${ }^{145}$, dentre outros métodos, ao que se denomina destinação final. É possível que se originem de: (i) produtos com defeito, mas passíveis de reuso ou reparos, (ii) produtos obsoletos, que chegaram ao final de sua vida útil, mas ainda assim possuem valor ou cujas partes e componentes ainda têm algum valor, (iii) produtos que não mais desejados ou (iv) que não chegaram sequer a ser vendidos, em razão de defeitos, prazo de validade vencido, excesso de estoque e (v) produtos objeto de recall ${ }^{146}$.

Já os rejeitos, ou seja, aqueles objetos que não podem mais ser reaproveitados de nenhum modo pelas tecnologias existentes, assim devem ser encaminhados para a

\footnotetext{
144 Informações disponíveis em: http://www.saude.go.gov.br/index.php?idMateria=85873. Acesso em 15.12.2014.

${ }^{145} \mathrm{O}$ reuso consiste basicamente em aproveitar o resíduo para a mesma finalidade original sem alterar suas propriedades físicas e químicas. O reuso é preferível a outros métodos de reaproveitamento, tal como a reciclagem, não apenas pela pequena complexidade, mas também porque requer um consumo menor energia. É possível que o reuso seja precedido de algum tipo de reparo (que é um conserto simples, equiparado a uma manutenção), recondicionamento (envolve mais ajustes do que o reparo, em regra, mediante a substituição de algum componente) ou renovação (conserto que visa a reequipar ou embelezar). A remanufatura é uma modalidade de reuso em que mantém-se os padrões originais do produto, mas se envolve a desmontagem, a limpeza, o recondicionamento de algumas partes, a remontagem e testes de uso prévio à reutilização dos produtos. Ou seja, não é possível o aproveitamento direto. Já a reciclagem pode ser definida como um conjunto de atividades que permitem o reprocessamento dos resíduos, de modo que possam ser utilizados para a fabricação de novos produtos. A reciclagem envolve a alteração física e/ou química dos resíduos diferentemente do reuso. Informações disponíveis em: http://www.calrecycle.ca.gov/reducewaste/define.htm. Acesso em 14.11.2014; e SOUZA, Marcelle Rodrigues de; SOUZA, Ricardo Gabbay de, Beneficiamento, 2014, p. 141-142.

${ }^{146}$ Cf. BLUMBERG, Donald F. Introduction to management of reverse logistics and closed loop supply chain processes, 2005, p. 34-35.
} 
disposição final. Nesse caso irá se destinar esses materiais aos aterros, à incineração, à compostagem, ao aproveitamento energético, coprocessamento ${ }^{147}$ etc.

Costuma-se definir os rejeitos como destituídos de funcionalidade que permita a reinserção ao ciclo produtivo. Em regra, não há a inclusão de rejeitos em segmentos produtivos. No entanto, é possível que o rejeito seja utilizado no aproveitamento energético ou no coprocessamento, por exemplo. De algum modo, a energia ou resultado gerado permite uma transação econômica. Os rejeitos podem tornar-se relevantes para o ciclo produtivo, quando houver o aproveitamento energético, haja vista a dependência das matrizes energéticas para a produção de diversos bens e materiais. Contudo, a inserção no ciclo econômico se dá de modo reflexo, porque o rejeito é transformado em energia e não propriamente reinserido na cadeia produtiva, seja integral ou parcialmente. Além disso, em muitos casos o rejeito é aterrado e não permitirá a reinserção na cadeia produtiva. Essa diferença é relevante para fins de aplicação da legislação que dispõe sobre resíduos ${ }^{148}$.

Ainda ocorre de muitos resíduos serem descartados de modo incorreto, o que poderá fazer com que se misturem com determinados materiais que impossibilitem o seu reaproveitamento, tornando-se, desse modo, rejeitos ${ }^{149}$. Nessa linha adverte ELISABETH GRIMBERG:

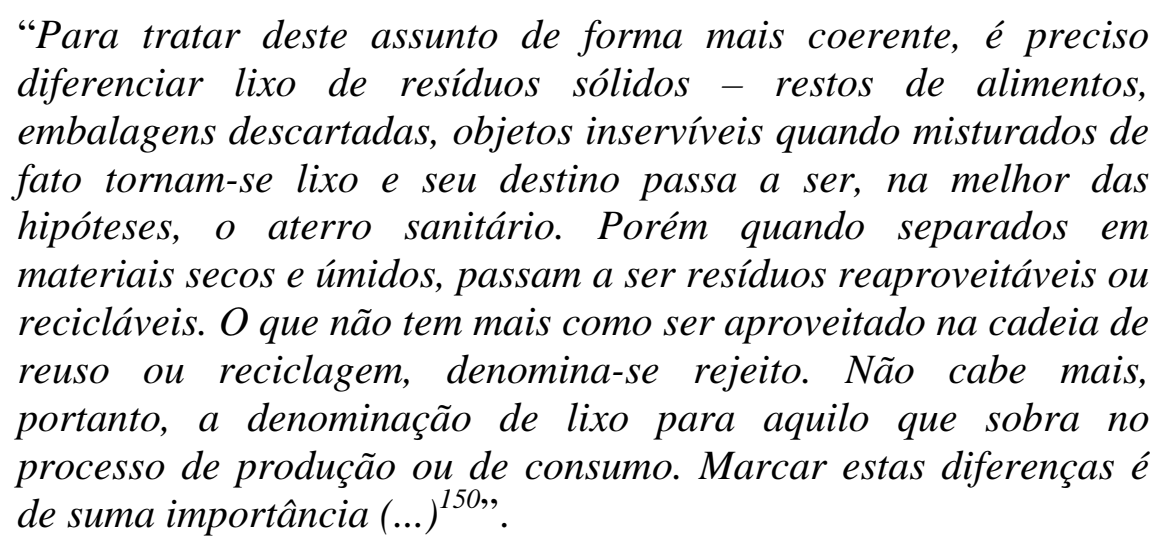

${ }^{147}$ O coprocessamento é uma técnica, regulamentada pela Resolução 264/1999 do CONAMA, que consiste na utilização de resíduos inservíveis, como pneus, para gerar energia que servirá para substituir a utilização de combustíveis na fabricação do cimento. A Petrobras desenvolveu um processo, denominado Petrosix, para extrair combustível a partir da rocha de xisto pirubetuminoso. Estima-se que a cada 1 tonelada de pneus coprocessados são produzidos "530 kg de óleo, $40 \mathrm{~kg}$ de gás, $300 \mathrm{~kg}$ de negro de fumo e $100 \mathrm{~kg}$ de aço". Para maiores informações, consulte-se: LAGARINHOS, Carlos Alberto F.; TENORIO, Jorge Alberto S., Tecnologias utilizadas para a reutilização, reciclagem e valorização energética de pneus no Brasil, 2008.

${ }^{148} \mathrm{O}$ tema será aprofundado ao longo deste capítulo.

${ }^{149} \mathrm{O}$ óleo lubrificante, por exemplo, ao entrar em contato com combustíveis, água, solvente ou tinta tem impossibilitada a sua reciclagem, a qual se denomina rerrefino. Informações disponíveis em: http://www.sindirepa-sp.org.br/pdfs/guia.pdf, p. 27. Acesso em 12.11.2014.

${ }^{150}$ GRIMBERG, Elisabeth, A Política Nacional de Resíduos Sólidos: a responsabilidade das empresas e a inclusão social, 2004. 
Os resíduos assumem, portanto, uma dupla faceta: por um lado, caracterizam-se como bens ou produtos que perderam suas funcionalidades ou tornam-se apenas desinteressantes ao seu detentor. Por outro lado, os resíduos podem ser reaproveitados, o que sob esse aspecto os tornam úteis. Nesse caso, são reutilizados com ou sem alteração das propriedades físicas ou químicas. No caso de os resíduos sofrerem essas alterações de suas propriedades para que se permita a reinserção no processo produtivo, atribui-se a classificação de matéria-prima secundária ${ }^{151}$.

Mediante a realização de uma gestão adequada, também é possível atribuir-se um valor econômico aos resíduos, o que poderá conferir lucro àqueles que o gerem ${ }^{152}$. Quanto mais elevados forem os custos das matérias-primas primárias ou os custos de disposição de resíduos em aterros, maior é o estímulo ao reaproveitamento dos resíduos ${ }^{153}$.

O presente trabalho abordará apenas os resíduos sólidos urbanos, como os resíduos industriais, domiciliares, comerciais, da área da saúde, excetuando-se aqueles resíduos regidos por legislação específica, como o caso dos resíduos radioativos.

\subsection{Diretrizes e regulamentações em matéria de resíduos: o contexto europeu e norte- americano}

Há algum tempo a União Europeia tem se preocupado em traçar diretrizes que possibilitem o tratamento e a eliminação adequada de resíduos. Na década de 70 foi editada a Diretiva 75/439/CE, que dispunha sobre a eliminação de óleo usado. Nos anos 90 foram instituídas outras diretivas como: a Diretiva 91/689/CE para regular a gestão de resíduos perigosos, a Diretiva 94/62/CE sobre embalagens e resíduos de embalagens e a

\footnotetext{
${ }^{151}$ A matéria-prima denominada secundária é aquela que pode ser reinserida em algum ciclo produtivo. É oriunda de algum produto anteriormente produzido ou decorrente do processo de produção, como sobras de materiais. Não necessariamente o produto precisa ser inserido na mesma cadeia produtiva da qual se originou. Reputa-se que pode ou não haver a necessidade ou não de tratamento prévio do resíduo para o seu reaproveitamento. No entanto, esse entendimento não é uníssono. No Decreto Legislativo italiano 4/2008, por exemplo, diferencia-se matéria-prima secundária - como aquela que deve ser proveniente de algum processo de tratamento - do subproduto - que basicamente não requer qualquer tipo de tratamento para ser reinserido no sistema produtivo. A distinção implica a diferenciação do regramento aplicável, se houver tratamento prévio aplica-se o direito dos resíduos, que é mais rigoroso, e no outro caso não. Esse tema apresenta controvérsias que fogem ao escopo do presente trabalho, por tal razão não serão aprofundadas. Sobre o tema, confira-se: D’ANDREA, Giovannella; PACINI, Nic, New Decree Clarifies Law on Secondary Raw Materials and By-products, 2009. No mesmo sentido, veja-se a sentença 41016 da Corte de Cassação Italiana, de 21.10.2010. $\quad$ Disponível em: http://www.internationallawoffice.com/newsletters/detail.aspx?g=d3ff37c4-4ad1-4e33-b858-1cfe04ad5519. Acesso em 25.07.2014.

${ }^{152}$ ARAGÃO, Maria Alexandra de Souza, O Direito dos Resíduos. Cadernos do CEDOUA, 2003, p. 10.

${ }^{153}$ ARAGÃO, Alexandra, Os resíduos e a sua gestão internacional, 2006, p. 280.
} 
Diretiva 1999/31/CE relativa à disposição de resíduos em aterros. Posteriormente, a Diretiva 2002/96/CE tratou dos resíduos de equipamentos eletroeletrônicos ${ }^{154}$.

A Diretiva 2006/12/CE tratou da gestão coordenada de resíduos, de modo a unificar o tratamento do tema no âmbito comunitário. Abordou-se, dentre outros aspetos, (i) a valorização dos resíduos como "matéria-prima secundária”, por meio do reuso, da reciclagem ou de remanufatura ${ }^{155}$, previamente à disposição final, assim como (ii) os métodos de disposição final, como a incineração e a aterragem. Essa diretiva representou um grande avanço para a gestão dos resíduos, pois consolidou matéria, que, até então, se encontrava pulverizada.

Posteriormente, a Diretiva 2008/98/CE, que revogou a Diretiva 2006/12/CE, passou, dentre outras medidas, a reforçar a necessidade de redução da produção de resíduo e da adoção de medidas destinadas à prevenção ${ }^{156}$. Isso por meio de uma gestão diferenciada, na qual o resíduo deixou de ser individualmente considerado, o que envolve, tradicionalmente, métodos de disposição final. Para isso, introduziu-se a análise do ciclo de vida dos produtos - ACV.

\subsubsection{Avaliação do ciclo de vida dos produtos}

De modo suscinto, essa avaliação do ciclo de vida do produto pode ser feita sob a perspectiva: (i) “do berço à cova - cradle to grave”, que se refere desde o período de obtenção dos recursos da natureza até a sua destinação final. Ou seja, o que for produzido deverá ser reciclado, incinerado ou disposto em aterro sanitário e, mais recentemente, cogita-se (ii) “do berço ao berço - cradle to cradle”, que visa não apenas à destinação final dos rejeitos, mas também a estimular o reaproveitamento de todos os resíduos como matéria para a produção de novos bens e mercadorias. O último método tem sido

\footnotetext{
${ }^{154} \mathrm{O}$ rol de diretivas indicado é meramente exemplificativo, pois existem outras disposições em matéria de resíduos que foram editadas nesse período. Além disso, algumas dessas diretivas encontram-se revogadas. A Diretiva 2008/98/CE substituiu as Diretivas 75/439/CE, 91/689/CE e 2006/12/CE. A Diretiva 2002/96/CE foi revogada pela Diretiva 2012/19/CE, de modo que são indicadas apenas para se situar a cronologia incial de desenvolvimento da temática no âmbito europeu.

${ }^{155}$ Nessa linha, confira-se: “(...) 3R ou reduzir, reutilizar e reciclar são prioridades intuitivas da gestão de resíduos presentes directa ou indirectamente na legislação e na Estratégia Comunitária de Gestão de Resíduos (...). Aprovada pela Resolução do Conselho, de 24 de fevereiro de 1997”. (ARAGÃO, Maria Alexandra de Souza, Direito Administrativo dos Resíduos, 2009, p. 31).

${ }^{156}$ Essa prevenção pode se dar tanto na fase de produção como na fase de gerenciamento dos resíduos. Segundo MARIA ALEXANDRA DE SOUZA ARAGÃO: "São dois os entendimentos possíveis do princípio da prevenção no âmbito do Direito dos Resíduos: a) a prevenção de resíduos - uma actuação preventiva a priori (...) baseada em normas que se aplicam anteriormente à existência de resíduos, e cuja finalidade é evitar a sua produção; b) a prevenção dos danos - uma actuação preventiva mas a posteriori (...) baseada em normas que se aplicam posteriormente ao surgimento dos resíduos e cuja finalidade é fomentar a boa gestão dos resíduos"- grifos no original. (O Direito dos Resíduos. Cadernos do CEDOUA, 2003, p. 12).
} 
considerado como o mais adequado, porque possibilita o melhor aproveitamento dos resíduos $^{157}$.

A ACV exige uma avaliação cautelosa de todas as etapas da cadeia produtiva para se determinar qual a melhor destinação que cada resíduo deverá ter. Com isso se permite a adoção de métodos de tratamento diversos da incineração e da aterragem, o que viabiliza a reinserção dos resíduos na cadeia produtiva, ao invés, da sua mera degradação. Com isso, reforça-se a valorização do resíduo, visto que lhe é possível atribuir um valor econômico.

A ACV também exige ${ }^{158}$ novos métodos de produção, que envolvem, por exemplo, novas concepções de design dos produtos, estratégias diferenciadas de marketing $^{159}$, métodos produtivos que requeiram um consumo menor de energia e o uso de materiais que facilitem os processos de reaproveitamento.

\subsubsection{A gestão de resíduos na União Europeia}

A União Europeia atua, portanto, com enfoque nas políticas relacionadas à gestão de resíduos que visem a reduzir impactos ambientais e sanitários para que seja possível melhorar a eficiência na utilização dos recursos, de modo a se evitar o desperdício de recursos, os quais devem ser reinseridos, sempre que possível, na cadeia produtiva. Tal medida visa à redução da necessidade de se recorrer ao uso dos recursos naturais ${ }^{160}$, além do que agrega valor ao resíduo, que pode ser comercializado ${ }^{161}$ como matéria-prima secundária. Ademais, essa medida pode inclusive propiciar o crescimento das economias europeias.

Mesmo diante desses avanços em termos de regulação e legislação, na prática, os resultados ainda não são totalmente satisfatórios. Estima-se que, em 2011, na União

157 Sobre o tema, consulte-se: MCDONOUGH, William; BRAUNGART, Michael. Cradle to Cradle: Remaking the Way We Make Things, 2012.

${ }^{158}$ Essas novas concepções podem vir a ser impostas como deveres ao setor empresarial. Na Alemanha, por exemplo, “(...) foi editada a Lei de Economia de Ciclo Integral e Gestão de Resíduos, em 1994, estabelecendo a responsabilidade do fabricante por todo o ciclo de vida do produto. Na sequência, tal lei alemã de resíduos veio a ser substituída pela (...) Kreislaufwirstchaftsgesetz - KrWG. (LEMOS, Patrícia Faga Iglecias; MENDES, João Múcio Amado, Resíduos eletroeletrônicos e seus aspectos jurídicos no Brasil, 2014. p. 55).

159 Sobre o tema, consulte-se: PAIVA, Teresa; PROENÇA, Reinaldo. Marketing Verde, 2011.

160 Being wise with waste: the EU's approach to waste management. Luxembourg: European Commission, 2010, 2 p. $2 . \quad$ Disponível em: http://ec.europa.eu/environment/waste/pdf/WASTE\%20BROCHURE.pdf. Acesso 15.09.2014.

${ }^{161}$ Note-se que o resíduo, ao menos no atual contexto, não se confunde com a mercadoria, muito embora seja possível the agregar algum tipo de valor. ALEXANDRA ARAGÃO ensina: “(...) os resíduos são, por definição, coisas cuja produção não foi o objetivo principal da actividade que os gerou. Sejam resíduos da indústria extractiva ou transformadora, resíduos da actividade comercial ou resíduos de consumo, são coisas que não têm interesse para quem as produziu, e que, por isso mesmo, pretende desfazer-se delas”. (Direito Administrativo dos Resíduos, p. 15). 
Europeia foram geradas 2,5 bilhões de toneladas de resíduos. Desse total apenas $40 \%$ foi reciclado ou reutilizado ${ }^{162}$. Segundo dados da própria União Europeia, a cada dezesseis toneladas de material apenas seis toneladas são reinseridas na cadeia produtiva novamente ${ }^{163}$, ou seja, tornam-se matéria-prima secundária. O restante acaba indo para aterros ou sendo incinerado. Desse modo, resta boa parte dos resíduos ainda sem o aproveitamento devido ou a destinação adequada.

Por tal razão, têm-se aprofundado as discussões na Europa. Constata-se que não é mais suficiente discutir e implementar medidas que apenas visem a destinar os rejeitos aos aterros ou incineradores, sendo necessário se avaliar uma questão anterior, que é evitar ao máximo o encaminhamento de resíduos a esses locais. E isso exige, imprescindivelmente, uma reformulação dos modos de produção e consumo atualmente praticados ${ }^{164}$.

Nessa linha, em julho de 2014, por meio do Comunicado 2014/0397/CE, a União Europeia divulgou a proposta legislativa para revisar as Diretivas 2008/98/CE (marco regulatório dos resíduos), 1999/31/CE (diretiva sobre aterros) e 94/62/CE (diretiva sobre embalagens e resíduos de embalagens), que atualmente tratam da gestão dos resíduos sólidos em âmbito europeu. Um dos elementos centrais é justamente a redução da produção e a maximização da utilização dos resíduos produzidos a fim de se reduzir as quantidades encaminhadas aos aterros.

É importante que essas metas de redução do volume de resíduo produzido não sejam cumpridas ao custo da degradação ambiental de regiões de outras localidades nacionais. Há uma prática muito frequente e condenável de alguns países europeus exportarem rejeitos, grande parte composta de eletroeletrônicos, para países menos desenvolvidos, que não possuem condições financeiras, econômicas e tecnológicas para dar lhes dar uma destinação final adequada ${ }^{165}$.

\footnotetext{
${ }^{162}$ Informações obtidas no Comunicado 2014/0397/CE, disponível em:. Acesso em 29.07.2014.

${ }^{163}$ Dados disponíveis em: http://ec.europa.eu/environment/waste/index.htm. Acesso em 20.07.2014. Note-se que em algumas situações o produto obtido por meio de algum dos modos de reprocessamento pode acarretar na perda de qualidade, que implicará no aproveitamento em outros segmentos de produtos.

164 A lógica da obsolência programada é muito praticada em diversos setores, sobretudo de equipamentos eletroeletrônicos, e consiste em se reduzir a vida útil dos produtos, de forma a obrigar os consumidores a adquirirem produtos com uma frequência muito maior, o que aumenta a produção de resíduos e rejeitos. Há um interessante documentário sobre o tema da obsolência programada que foi dirigido por COSIMA DANNORITZER, intitulado The Lightbulb Conspiracy, disponível em: http://www.academia.edu/1999344/Film_review_of_The_Lightbulb_Conspiracy by_Cosima_Dannoritzer. Acesso em 12.08.2014.

${ }^{165}$ Para uma análise mais detalhada do tema confira-se: MIGUEZ, Eduardo Correia. Logística reversa como solução para o problema do lixo eletrônico: benefícios ambientais e financeiros, 2010, p. 37 e ss.
} 


\subsubsection{A gestão de resíduos nos Estados Unidos}

Nos Estados Unidos também há uma série de regulamentações em matéria de resíduos sólidos. A primeira lei editada sobre o tema se deu em 1965 (Solid Waste Disposal Act). A coleta e destinação final dos resíduos era uma atribuição regional e local, mas a partir dessa lei reputou-se que a problemática da eliminação dos resíduos passa a ser uma questão de âmbito nacional. A assistência financeira federal para o desenvolvimento de métodos e novos processos de eliminação dos resíduos tornou-se, a partir de então, essencial.

Em 1976, o congresso norte-americano aprovou a Lei de Conservação e Recuperação dos Recursos (Resource Conservation and Recovery Act - RCRA). Por meio dessa lei estabeleceram-se metas nacionais para proteção da saúde humana, para contenção dos riscos relacionados à eliminação de resíduos, assim como para fomentar a conservação dos recursos naturais. Também se previu a necessidade de redução da quantidade de resíduos gerada, o estímulo à reciclagem e à disposição final ambientalmente adequada. $\mathrm{O}$ RCRA divide a regulamentação em três eixos principais. O primeiro eixo é dedicado aos resíduos industriais não perigosos e resíduos sólidos urbanos, no qual se define critérios para instalação e construção de aterros e formas de eliminação dos resíduos. Os outros dois eixos referem-se aos resíduos perigosos ${ }^{166}$.

O apêndice 256.10 prevê que o plano de gestão de resíduos deve conter as responsabilidades que são atribuíveis aos entes federativos e também ao setor privado.

Em 1984, houve alterações no RCRA com vistas a aumentar a autoridade da EPA, que se torna responsável por desenvolver e aprovar as regulamentações necessárias a implementação dessa lei. Todos os regulamentos propostos devem ser publicados pela EPA para informar aqueles que tenham intenção de participar, propondo sugestões e críticas ao modelo. Após consolidadas as proposições, a EPA edita o regulamento, que integrará o Código Federal de Regulações (Code of Federal Regulations). As diretrizes sobre resíduos sólidos são dispostas das partes 239 a 259. Na parte 240 dispõe-se, por exemplo, sobre diretrizes para o tratamento térmico de resíduos sólidos, a parte 256 aborda diretrizes para o desenvolvimento e implementação de Planos Estaduais de Gestão de Resíduos Sólidos, a parte 258 envolve os critérios para implantação e operação de aterros de resíduos sólidos municipais ${ }^{167}$.

\footnotetext{
${ }^{166}$ Informações disponíveis em: http://www.epa.gov/osw/laws-regs/rcrahistory.htm. Acesso em 14.11.2014. 167 Informações disponíveis em: http://www.epa.gov/osw/laws-regs/regs-non-haz.htm. Acesso em: 14.11.2014.
} 
Já em 1992 reforçou-se a aplicação da RCRA no âmbito das instalações federais. Também houve flexibilização regulatória para a eliminação de certos resíduos em aterros. Interessante notar que a RCRA não se aplica a locais abandonados ou históricos, que são abrangidos por outra lei (Comprehensive Environmental Response, Compensation, and Liability Act - CERCLA) ${ }^{168}$.

O aumento da reutilização e da reinserção dos resíduos na cadeia produtiva é uma política bastante visada pela legislação norte-americana. Isso resta evidente no Sétimo Programa de Ação Ambiental (7th Environment Action Programme - EAP), no qual foram traçadas diretrizes de políticas ambientais que devem vigorar até 2020, com vistas a produzirem resultados práticos de longo prazo - até 2050.

Conforme disposto no sétimo EAP, espera-se que ocorra um aumento da eficiência na reinserção dos resíduos no ciclo econômico, em cerca de 70\%, até 2030, com o objetivo de eliminar progressivamente a disposição de alguns tipos de resíduos não perigosos - como papel, metais, vidro e bio-resíduos. A reciclagem e a reutilização de embalagens devem chegar em $80 \%$ até esse mesmo ano ${ }^{169}$, de modo que a economia deva adquirir um caráter “circular”, ou seja, nenhum resíduo ou nenhum recurso natural será desperdiçado, ocorrendo o manejo sempre de maneira sustentável ${ }^{170}$.

Segundo dados da EPA, em 2012, cerca de 87.000.000 de toneladas de resíduos foram reciclados ou encaminhados para compostagem, o que representa um aumento de milhões de toneladas desde os anos $80^{171}$.

Mas também há um nítido estímulo à adoção de práticas que possibilitem a prevenção de resíduos. Nesse sentido, a EPA incentiva o reuso como uma forma de redução do consumo, porque não gera a produção de novos produtos, economizando recursos, energia e custos de transporte ${ }^{172}$.

Note-se que a EPA traça diretrizes gerais e há políticas regionais que definem as políticas mais específicas a serem aplicadas.

\footnotetext{
168 Informações disponíveis em: http://www.epa.gov/osw/laws-regs/regs-non-haz.htm. Acesso em: 14.11.2014.

${ }^{169}$ Há inclusive metas específicas para alguns tipos de materiais como papel, vidro e alumínio (90\%), plásticos (60\%) e madeira (80\%).

${ }^{170}$ Os principais objetivos do EAP podem ser consultados em: http://ec.europa.eu/environment/newprg/. Acesso em 26.7.2014.

${ }^{171}$ Fonte: http://www.epa.gov/osw/nonhaz/municipal/index.htm. Acesso em 14.11.2014.

172 UNITED STATES ENVIRONMENTAL PROTECTION AGENCY - EPA, Municipal Solid Waste Source Redution. A Snapshot of State Initiatives, 1998, p. 3. Dados em: http://www.epa.gov/osw/nonhaz/municipal/pubs/snapshot.pdf. Acesso em 14.11.2014.
} 


\subsection{A prevenção de resíduos sólidos}

A falta de gestão de resíduos sólidos, com a consequente disposição final inadequada e sem planejamento, ao longo de tantas décadas, criou problemas de diversas ordens, como a falta de espaços físicos para a aterragem, a contaminação do solo e mananciais e doenças, os quais têm se tornado cada vez mais complexos de serem resolvidos. TASSO ALEXANDRE RICHETTI PIRES CIPRIANO bem destaca que:

“o (...) esgotamento progressivo da disponibilidade e capacidade de áreas para aterragem e incineração - sintoma esse particularmente sentido nos países de menor dimensão geográfica e maior densidade demográfica, como é o caso, por exemplo, da Europa - pôs em xeque a suficiência do direito da eliminação de resíduos, apontando para a necessidade de se evitar e reduzir a geração dos mesmos. Até porque isso acarreta a existência de um menor volume de resíduos com que se preocupar (eliminar) ${ }^{173}$ ”.

O acúmulo de resíduos existente se deve, em grande medida, à falta de estruturação completa da cadeia produtiva e da análise de todo o ciclo de vida dos produtos. Mas não se pode ignorar a causalidade existente entre consumo e a geração de resíduos.

A prevenção é visada por diversas legislações e atualmente praticamente todos os conceitos de logística reversa abarcam essa preocupação. Isso, em grande medida, reflete a dificuldade de gestão do passivo de resíduos existente e que é bastante significativo. A falta de espaços físicos e também de tecnologias adequadas exige a prevenção da geração de resíduos.

A falta de aproveitamento dos resíduos na cadeia produtiva seja por meio da reciclagem, da reutilização, dentre outros métodos, gera diversos problemas, visto que não permite a adequação da cadeia produtiva ao meio ambiente e social. Além disso, deixa-se de gerar diversos ganhos econômicos, como aqueles advindos da redução da utilização de matérias-primas primárias.

Um fluxo reverso adequado deve levar em conta não apenas o descarte de resíduos, mas também fases anteriores de concepção dos produtos, de definição do design, do nível de durabilidade dos materiais etc.

\footnotetext{
${ }^{173}$ A juridificação dos resíduos no Brasil, no prelo.
} 
Nesse sentido enfatiza JULIANA VIEIRA DOS SANTOS:

"Uma política que considere o fluxo de materiais deverá garantir que a legislação faça referência a momentos anteriores ao descarte, na extração de matéria-prima, na geração das embalagens e na própria compra dos produtos.

A gestão de resíduos sólidos urbanos, portanto, deve abranger todas as fases pelas quais passam os materiais, ou seja, deve abranger todo o circuito produtivo. O objetivo de uma política com estes pressupostos é reduzir a quantidade de matéria-prima sendo extraída a partir do aumento da fase de utilização de materiais ${ }^{174,}$.

Não é suficiente apenas a reinserção dos resíduos na cadeia produtiva, sendo preciso haver também a redução da escala de produção ${ }^{175}$. Tanto em razão do passivo ambiental existente como diante da escassez de matérias-primas.

Mas note-se que a prevenção pode se dar em qualquer etapa do ciclo produtivo, mas nas fases iniciais de concepção do produto tende a ser mais efetiva. Isso porque o desenvolvimento de tecnologias que permitam a modificação dos materiais podem facilitar os processos de reciclagem e de tratamento dos resíduos. Isso perpassa por novas concepções de design e de planejamento do final do ciclo de vida dos produtos ${ }^{176}$.

Outros dois aspectos devem ser enfrentados em relação à prevenção. Primeiro a prevenção deve ser encarada como um norte a ser atingido, ou seja, deve balizar a produção econômica, mas sem tender a um crescimento econômico zero ${ }^{177}$. Em segundo, a ideia de prevenção, ao menos a que tem sido esboçada nas legislações atuais, não parece

\footnotetext{
${ }^{174}$ A gestão dos resíduos sólidos urbanos: um desafio, 2009, p.74.

175 Sobre o tema TASSO ALEXANDRE RICHETTI PIRES CIPRIANO se manifestou: "Por ignorar o motivo pelo qual os resíduos são gerados, é dizer, por não questionar a razão da 'morte' dos produtos, reduzindo-se ao gerenciamento dos sintomas da problemática dos resíduos ao invés de se ocupar das suas verdadeiras causas (o consumo e os processos produtivos), o direito da eliminação de resíduos falha em fornecer uma solução apropriada diante do novo contexto produtivo-consumista e, como corolário, de geração de resíduos” (A juridificação dos resíduos no Brasil, no prelo).

${ }^{176}$ A respeito dos resíduos eletroeletrônicos destaca ANA PAULA BORTOLETO: "É preciso ir além de construir canais que possibilitem somente a transformação dos resíduos de pós-consumo em matéria-prima para novos produtos. A inovação dos materiais para a fabricação de EEE é outra vertente do problema, pois acompanha com a mesma velocidade a evolução tecnológica desses equipamentos. Muitos desses materiais chegam ao mercado sem a perspectiva do que ocorrerá ao final do seu ciclo de vida. Neste caso, cabe aos pesquisadores com altíssimos investimentos financeiros se ocuparem em achar soluções de reciclagem $e$ novos processos de tratamento para os REEE produzidos pelos novos materiais" (A Prevenção e a Análise do Ciclo de Vida na Gestão de Resíduos e Equipamentos Eletrônicos, 2014, p. 31).

${ }^{177}$ Para um aprofundamento sobre a noção de crescimento zero recomenda-se a leitura da seguinte obra: MEADOWS, Donella H.; RANDERS, Jorgen; MEADOWS, Dennis L.; BEHRENS, William W. The limits to growth: A report for the Club of Rome`s Project on the Predicament of makind, 1972.
} 
visar a eliminar o consumo, mas apenas a atingir patamares mais equilibrados entre o consumo, descarte e utilização de matérias-primas ${ }^{178}$.

\subsection{A Política Nacional de Resíduos Sólidos: o contexto brasileiro}

No Brasil a temática ganhou maior destaque com a edição da Lei 12.305/2010, que instituiu a Política Nacional de Resíduos Sólidos - PNRS ${ }^{179}$. O art. $9^{\circ}$ dessa lei dispõe que na gestão e no gerenciamento de resíduos sólidos “(...) deve ser observada a seguinte ordem de prioridade: não geração, redução, reutilização, reciclagem, tratamento dos resíduos sólidos e disposição final ambientalmente adequada dos rejeitos”.

Note-se que a legislação brasileira incorporou tanto a necessidade da adoção de práticas que modifiquem o modo de produção - que hoje, em grande medida, visa ao estímulo crescente e ilimitado de consumo - como práticas que minimizem a quantidade de resíduos depositados em aterros sanitários, com o estímulo à reutilização, à reciclagem, à compostagem, entre outros métodos.

Além disso, a PNRS requer um manejo mais cauteloso no tocante à disposição final adequada dos rejeitos. Tal situação exige do Poder Público e da sociedade civil uma nova estruturação do atual modelo de gestão dos resíduos sólidos.

O Ipea estima que o Brasil perde, anualmente, cerca de 8 bilhões de reais em razão do descarte inadequado de resíduos sólidos ${ }^{180}$. Mesmo nas localidades em que existe sistema de coleta de resíduos implantada, grande parte ainda recebe destinação irregular. Dados da pesquisa realizada pela Abrelpe (Associação Brasileira das Empresas de Limpeza Pública e Resíduos Especiais), no ano de 2012, revelam que 42\% do material encaminhado para disposição final é depositado em aterros controlados ou lixões, o que corresponde a cerca de 80 mil toneladas diárias ${ }^{181}$.

Há uma gama complexa de atividades e serviços que envolvem o gerenciamento de resíduos sólidos, que vão desde a coleta, o tratamento - que pode se dar

\footnotetext{
${ }^{178}$ RAMÓN MARTÍN MATEO assumindo que é impossível eliminar por completo o consumo, explicita que a prevenção pode ser pautada pela minimização, considerando-se que ao menos será viável reduzir aos menores patamares a produção. Isso exige, dentre outros fatores, que sejam produzidos produtos com maior durabilidade (Nuevo ordenamiento de la basura, 1998, p. 51).

${ }^{179}$ A Lei 12.305/2010 originou-se do PL 203/1991 do Senado. Para um aprofundamento sobre o processo de formulação dessa lei, consulte-se: ARAÚJO, Suely Mara Vaz Guimarães de; JURAS, Ilidia da Ascenção Garrido Martins. Comentários à Lei de Resíduos Sólidos. Lei no 12.305, de 2 de agosto de 2010 (e seu regulamento), 2011, p. 31-35.

180 Informações disponíveis no Portal de Meio Ambiente da UFRN, confira-se: http://www.meioambiente.ufrn.br/?p=5970. Acesso em 15.12.2014.

181 Panorama dos Resíduos Sólidos no Brasil, 2012. Dados disponíveis em: http://www.abrelpe.org.br/Panorama/panorama2012.pdf. Acesso em 15.12.2014.
} 
por meio da reciclagem, por exemplo -, e o armazenamento até a disposição final dos resíduos. Nessas diversas etapas, é necessária a adoção de tecnologias que permitam a maximização das atividades. É necessário qualificar a mão-de-obra existente, assim como investir na construção de infraestruturas (como aterros sanitários, usinas de compostagem, estações de transbordo), o que exige grandes proporções espaciais e tecnologias adequadas, além de investimentos em pesquisa tecnológica.

As infraestruturas necessárias variam de acordo com cada modalidade de resíduos, mas, de modo geral, requerem investimentos vultosos. Colocar a PNRS em prática envolve ainda medidas de educação social e ações de fiscalização das atividades realizadas, o que também demanda investimentos. A questão financeira, sem dúvidas, gera muitas dificuldades para diversos estados e, principalmente, municípios brasileiros.

Há diversos modos pelo qual se pode operacionalizar o gerenciamento de resíduos sólidos, seja por meio da (i) atuação direta; (ii) instituição de consórcios públicos, (iii) criação de autarquias (iv) instituição de empresas públicas e sociedades de economia mista; (v) fundações ou associações ${ }^{182}$, (vi) celebração de convênios; (vii) contratação administrativa, (vi) delegação a particulares, por meio de contrato de concessão, sendo que uma de suas modalidades poderá ser a parceria público-privada, dentre outras hipóteses que podem vir a ser estabelecidas ${ }^{183}$.

Mas, a PNRS, no art. 33, dispõe também sobre a obrigatoriedade de os fabricantes, importadores, distribuidores e comerciantes de determinados segmentos estruturarem e implementarem sistemas de logística reversa, de modo independente ao serviço público de limpeza pública e manejo de resíduos que seja prestado pelo poder público. Isso porque as políticas públicas relacionadas ao manejo de resíduos e rejeitos necessitam da participação intensa tanto do Poder Público como de empresários e dos próprios cidadãos, de maneira a se chegar a melhor solução possível em cada caso concreto. Cada qual possuirá papel relevante na condução dessas políticas. A atuação

\footnotetext{
${ }^{182}$ Na Alemanha, fabricantes e os comerciantes de embalagens criaram uma sociedade sem fins lucrativos chamada Duales System Deutschland GmbH (DSD) para organizar a coleta, a seleção e a valorização dos vasilhames e dos resíduos comerciais. Essa atividade é desenvolvida mediante recursos obtidos com o pagamento de taxas pelas empresas beneficiadas com o exercício das atividades. Os valores a serem pagos são estabelecidos em função do volume de embalagens a ser reprocessado. (LEMOS, Patrícia Faga Iglecias; MENDES, João Múcio Amado, Resíduos eletroeletrônicos e seus aspectos jurídicos no Brasil, 2014. p. $55)$.

${ }^{183}$ O presente trabalho tem por objetivo a análise específica do mecanismo da logística reversa, desse modo não irá aprofundar questões relativas à atuação direta ou indireta da Administração Pública no manejo de resíduos.
} 
coordenada e integrada em todas as atividades, sempre que possível, é imprescindível para a obtenção de bons resultados.

\subsection{A regulação estatal como mecanismo de intervenção no domínio econômico e de proteção ambiental}

O Estado contemporâneo passa, como visto na parte inicial desse trabalho, pela reformulação de suas diretrizes, o que tem demandado a transformação do modelo de organização estatal, que passou, então, a se retirar do âmbito de determinadas atividades. Em contrapartida também se percebeu que apenas a iniciativa privada não é apta a desempenhar as atividades delegadas pelo Estado. Assim caminha-se para um contexto de um Estado ordenador do domínio econômico que atua em conjunto com os privados ${ }^{184}$. Nessa linha asseveram GORDON TULLOCK, ARTHUR SELDON e GORDON L. BRADY:

"Não faz muito tempo, a simples prova de que a economia não funcionava perfeitamente era visto como motivo para a intervenção do governo. Hoje se reconhece que o governo também não funciona perfeitamente; as opções, portanto, não são entre dois instrumentos imperfeitos (...) não se deve cometer o erro que (...) foi criticado anteriormente: se o governo desempenha mal certas funções, isto não implica necessariamente que o mercado irá desempenhá-las melhor. A escolha pública enfatiza que as alternativas do governo e do mercado devem ser comparadas em bases similares $^{185,}$.

Esse processo de modificação permite ao Estado assumir uma posição de

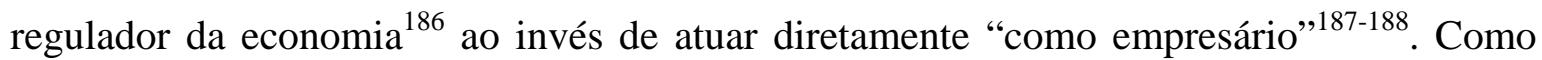
destaca ANA ROQUE, a liberalização do mercado não implica a retirada da influência do Estado, que pode ser conciliada por atividades interventivas indiretas como a regulação.

\footnotetext{
${ }^{184}$ Isso inclusive porque a manutenção de antagonismos no desenvolvimento de políticas públicas ambientais e econômicas não contribuirá para o atingimento de soluções satisfatórias, visto que ambos os setores são vitais para a existência humana. (TERÁN, Antonio Burgués; MORA, Alvaro López, ¿Apertura por apertura o desarrollo sostenido?, 1996, p. 25).

${ }^{185}$ Falhas do governo: uma introdução à teoria da escolha pública, 2005, p. 24.

186 A regulação não envolve a aplicação direta de recursos financeiros estatais para a consecução das atividades econômicas, mas há um custo bastante elevado com a redução da assimetria de informações, porque o Estado não executa a atividade, mas deve conhecê-la suficientemente bem para que possa planejar e fiscalizar a sua execução.

187 SANTOS, António Carlos dos; GONÇALVES, Maria Eduarda; MARQUES, Maria Manuel Leitão. Direito Económico. 4. ed., 2001, p. 67.

${ }^{188} \mathrm{O}$ fato de haver uma valorização da atuação reguladora do Estado não significa a ausência de sua atuação direta, ou seja, como empresário, mas esse tipo de atuação tem se tornado secundária, em razão de suas limitações financeira.
} 
Mas para que isso se possível é necessário haver um planejamento e adequação da atuação estatal às circunstâncias fáticas ${ }^{189}$.

Mas forma de intervenção do Estado se altera qualitativa e quantitativamente ao longo dos tempos ${ }^{190}$. Em períodos pretéritos, por exemplo, as intervenções estatais se restringiam a um caráter proibitivo ou repressivo, que não induz o particular a execução de uma prestação, mas visa apenas a prevenir determinada conduta.

A abstenção ou a intervenção do Estado na modulação da atividade econômica é uma opção política ${ }^{191}$. Mas admite-se que hoje a atuação meramente corretiva não seja mais suficiente. Exige-se, desse modo, um papel mais interventivo ${ }^{192}$ por parte do Estado, visto que a autorregulação do mercado não se mostra faticamente viável ${ }^{193}$. A regulação do Estado $^{194}$ serve para corrigir erros do sistema econômico, que por meio de autorregulação não seriam suficientemente sanados, em alguns casos também se opta pela prevenção desses erros ${ }^{195}$.

Um exemplo que ilustra essa situação é a uniformização de medidas ambientais na Europa. Essa normatização iniciou-se nos anos 70, em razão da verificação de diversos problemas ambientais. O Estado percebeu que a atuação apenas a posteriori, ou seja, na fase de reparação do dano, mediante a imposição de responsabilização dos poluidores e compensação das vítimas, não era suficiente. O que fez surgir a necessidade da instituição de regulamentações da matéria ambiental ${ }^{196}$ e de algumas medidas preventivas ${ }^{197}$. Além

\footnotetext{
${ }^{189}$ Regulação do Mercado. Novas tendências, 2004, p. 10.

190 Como explica FLORIANO DE AZEVEDO MARQUES NETO: "Há autores que sustentam existir uma ampla discricionariedade nesta opção do poder público. Para estes, a Constituição não contém nenhum princípio ou parâmetro que limite a adoção de uma modalidade de intervenção mais intensa, sendo a legitimação democrática do governante eleito ou do legislador suficiente para permitir que, numa dado momento e num setor da economia, o Estado intervenha de forma intensa (...) entre nós, é Gilberto Bercovici. Outros seguem linha congênere, para dizer que não há parâmetro definido no texto constitucional a impedir mecanismos de intervenção mais intensos (...) a justificativa para intervenção estatal mais intrusiva dependeria ou da manifestação legislativa (...) ou da adoção de parâmetros hermenêuticos. (...) Digna de nota é a posição de José Vicente Santos de Mendonça” (O fomento como instrumento de intervenção estatal na ordem econômica, 2010, p. 59).

${ }^{191}$ MONCADA, Luis S. Cabral de. Direito Económico. 2. ed., 1988.

192 As políticas públicas podem ser implementadas por meio de intervenções estatais diretas ou indiretas na disciplina das atividades econômicas, como forma de influenciar a modificação dos padrões adotados.

193 DERANI, Cristiane. Direito Ambiental Econômico, p. 93.

${ }^{194}$ O presente trabalho tem por objetivo enfocar a regulação normativa, que se dá por meio da edição de leis, regulamentos, portarias, que ordenam e condicionam o comportamento socioeconômico. Como destaca MARÇAL JUSTEN FILHO: "Uma característica essencial da regulação reside na sua natureza (...) normativa”. (Curso de Direito Administrativo. 10 ed., 2014, p. 670).

${ }^{195}$ ROQUE, Ana. Regulação do Mercado. Novas tendências, 2004, p. 12.

196 A regulação ambiental normativa deve ser entendida como as disposições legais, regulamentares e quaisquer outras medidas que sejam impostas ao exercício de atividades econômicas com vistas a possibilitar a preservação ambiental. A regulação não precisa assumir apenas um viés impositivo, sendo possível que algumas medidas tenham caráter meramente promocional e de incentivo a determinadas ações ambientais protetivas.
} 
disso, a regulação diferenciada em cada localidade permitia a ocorrência de disparidade de custos entre as empresas que se submetiam a uma legislação mais rigorosa e outras menos rigorosas ou até mesmo em relação àquelas empresas que nem estavam submetidas a qualquer regulação, o que ocasionava problemas de competitividade ${ }^{198}$.

A gestão do meio ambiente, portanto, exige por parte do Estado uma orientação, limitação e condicionamento, com eventual sancionamento, das práticas sociais, individuais e empresariais ${ }^{199}$.

A regulação, sobretudo a normativa ${ }^{200}$, pode ser um instrumento útil para a atuação do Estado no domínio econômico ${ }^{201}$ e inclusive social com vistas à efetivação de procedimentos de proteção ao meio ambiente. Tais procedimentos são uma obrigação atribuída ao Estado por força do art. 225 da CF/88.

JOSÉ JOAQUIM GOMES CANOTILHO e JOSÉ RUBENS M. LEITE destacam a existência de dois modelos a partir do qual o Estado atua regulação dos problemas ambientais: um orientador e diretivo, que se preocupa com instrumentos impositivos de comando e direção e outro de flexibilização dos modos, formas e procedimentos que se reputam adequados para a proteção do meio ambiente. Mas os autores ressalvam que o ideal é a atuação estatal fugir dessa composição binária (imposição versus flexibilização) e adotar um modo de cooperação e controle de políticas ambientais ${ }^{202}$.

Mas destaque-se que independentemente do modo regulatório a ser escolhido e praticado, é preciso haver mecanismos de atualização periódica da regulação, especialmente daquela dita normativa. Sempre que necessário a regulação e os atos normativos deverão ser readaptados para evitar o engessamento de situações práticas que

\footnotetext{
197 Alguns exemplos de medidas preventivas: o estudo de impacto ambiental, licenciamento ambiental, zoneamento ecológico, seguros para riscos ambientais. Sobre o tema, confira-se: FREITAS, Vladimir Passos de; FREITAS, Mariana Almeida Passos de. Direito Administrativo e Meio Ambiente. 5. ed., 2014, p. 90105.

198 CANOTILHO, José Joaquim Gomes; LEITE, José Rubens M. Direito Constitucional Ambiental Brasileiro. 3. ed., 2010, p. 61-62.

199 SANTOS, António Carlos dos; GONÇALVES, Maria Eduarda; MARQUES, Maria Manuel Leitão. Direito Económico. 4. ed., 2001, p. 432.

${ }^{200}$ Para ANTÓNIO CARLOS DOS SANTOS, MARIA EDUARDA GONÇALVES, MARIA MANUEL LEITÃO MARQUES o Estado pode atuar condicionando (seja positiva ou negativamente), fiscalizando, planejando ou promovendo as atividades. Esses autores dividem a intervenção estatal em funções: função de planejamento: o que envolve definição de estratégias de proteção ambiental e a verificação das áreas a serem protegidas; função normativa: definição de critérios normativos e a regulamentação da utilização dos recursos naturais e a função fiscalizadora: envolve o controle e vigilância do cumprimento das normas ambientais. (Direito Económico. 4. ed., 2001, p. 67-68).

201 Se o Estado atuar no setor empresarial ele também deverá se sujeitar as regras de regulação que se aplicam aos agentes econômicos ditos privados.

${ }^{202}$ Direito Constitucional Ambiental Brasileiro. 3. ed., 2010, p. 12.
} 
não mais se verificam, para eliminar disposições que se mostraram inadequadas, ou ainda para regular alguma nova situação fática etc.

\subsection{A importância da participação social na formulação de normas ambientais}

A eficácia da lei depende muito da aceitação e compreensão de sua utilidade por parte dos destinatários a que se aplica ${ }^{203}$. Por isso a regulação não deve ser feita de modo autoritário, primeiro porque tal prática não se coaduna com um Estado Democrático de Direito e segundo, pois reduz a sua eficácia.

Assim a participação dos cidadãos na formulação da regulação é essencial para evitar distorções na aplicação da regulação e na normatização ${ }^{204}$. A viabilidade prática de aplicação das previsões normativas também depende da observância de garantias em relação aos direitos dos particulares e entidades privadas. Como destaca DIOGO DE FIGUEIREDO MOREIRA NETO:

"A participação regulatória, como característica legitimatória da
atuação reguladora, se realiza pela garantia da publicidade,
portanto da plena visibilidade dos atos e dos processos de
regulação; pela garantia de plena abertura processual aos

${ }^{203}$ A regulação normatiza aspectos econômicos, sociais e ambientais possibilitando efetivar as políticas públicas nesses setores. Desse modo permite "criar, garantir e manter um funcionamento equilibrado do todo social”. (ROQUE, Ana. Regulação do Mercado. Novas tendências, 2004, p. 26).

${ }^{204}$ Um estudo da professora CRISTIANA LOSEKANN da Universidade Federal do Rio Grande do Sul apurou a margem de participação da sociedade civil na política ambiental entre os anos de 2003 e 2008 . A Conferência Nacional do Meio Ambiente foi indicada pela autora como um espaço em que, principalmente, em 2006, permitiu a discussão de políticas públicas fortalecendo a participação social na tomada de decisão política, sendo um espaço de participação social partilhado por diversos agentes da sociedade civil (setor empresarial, povos indígenas, comunidades tradicionais, população como um todo) e ainda o setor governamental, que é responsável pela sua organização. Mas a professora gaúcha identificou algumas limitações em relação: (i) às demandas que conflitam com os interesses econômicos, que tendem a ser rejeitadas; (ii) à baixa qualidade das deliberações obtidas, que muitas vezes já existem ou são inviáveis e (iii) a ausência de periodicidade e a descontinuidade das conferências. O Conselho Nacional de Meio Ambiente CONAMA foi apontado pela autora como um órgão de sofisticada institucionalização, que possibilita a discussão interna das questões, que observa a diversidade cultural em sua composição (mediante a representação de trabalhadores rurais, populações tradicionais, grupos indígenas, sindicatos, entidades ambientalistas etc.). Os cargos do Ministério do Meio Ambiente, a partir de 2006, passaram a contar com uma estrutura burocrática mais organizada, visto que em período anterior o número de contratados concursados era muito reduzido, estima-se que de oitocentos funcionários apenas vinte fossem concursados. A participação no MMA é tida como de alcance médio na participação social, porque não é capaz de garantir os interesses ambientais indicados quando estão em contraposição a grandes interesses econômicos. A ação judicial também foi mencionada com um modo de efetividade do processo participativo - nesse sentido foi indicada a ação civil pública. Mas também se destacou a importância das denúncias para o desencadeamento do processo judicial. (Participação da sociedade civil na política ambiental do Governo Lula, 2012. Disponível em: http://www.scielo.br/scielo.php?script=sci_arttext\&pid=S1414753X2012000100012\&lng=en\&nrm=iso. Acesso em 15.12.2014). 
administrados e pela possibilidade ou obrigatoriedade legal de tomar decisões com a participação dos administrados ${ }^{205}$ ",

Além disso, uma decisão participativa também permite uma solução mais legítima, porque envolve uma maior coordenação de diversos interesses que a legislação ambiental tem de compor ${ }^{206}$. Isso se torna mais relevante quando a composição feita pela lei envolver interesses conflitantes ${ }^{207}$.

\subsection{Incentivos normativos a uma atuação sustentável: a gestão de resíduos sólidos}

O tema da gestão de resíduos exige a colaboração de diversos setores e a regulação normativa deve propiciar a integração de ações e uma relação mais dialógica entre os envolvidos. Interessante reportar à observação de ALEXANDRE PEÑALVER CABRÉ, em análise ao tema dos resíduos sólidos, ainda que com base no direito espanhol:

"As novas tendências políticas e legislativas em matéria de resíduos implicam uma intervenção pública na economia para reconduzir o processo de produção e consumo aos novos objetivos de redução, reutilização e reciclagem dos resíduos. Este fenômeno está estreitamente ligado ao processo de transformação do papel do Estado na economia ${ }^{208, " ~(t r a d u c ̧ a ̃ o ~ l i v r e) . ~}$

A regulação e a produção de normas podem ser utilizadas para a obtenção de mudanças no padrão de produção e consumo, que visem à redução da utilização dos recursos naturais, que permitam minimizar os impactos ambientais, mediante a redução da utilização de energia, matérias-primas, substâncias nocivas, que permitam a redução da emissão de poluentes e do volume de resíduos.

A degradação ambiental provocada pelas atividades e especificamente pelos resíduos, que é o tema ora analisado, não era considerada parte integrante do custo das empresas. A regulação do sistema de mercado considerava os danos ambientais como uma externalidade, que representava um custo apartado dos preços ou serviços. Esse era um custo que as empresas não estavam dispostas a pagar. As medidas de punição não foram aptas a evitar que esses custos fossem repassados difusamente para a toda a sociedade ${ }^{209}$.

\footnotetext{
${ }^{205}$ Direito Regulatório, 2003, p. 170.

${ }^{206}$ Os empreendimentos de grande impacto ambiental têm contado com a participação popular nos processos de licenciamento ambiental, por meio das audiências públicas.

${ }^{207}$ DERANI, Cristiane. Direito Ambiental Econômico, 1999, p. 93.

${ }^{208}$ La regulación municipal de los resíduos, 1997, p. 61.

209 SANTOS, António Carlos dos; GONÇALVES, Maria Eduarda; MARQUES, Maria Manuel Leitão. Direito Económico. 4. ed., 2001, p. 432-433.
} 
Apenas proibir determinada prática ou punir o poluidor não se mostrou eficaz, em partes porque, em muitos casos, é difícil a identificação precisa do agente poluidor. Assim, acaba se tornando mais fácil impor medidas que impeçam a poluição. No caso de descarte de resíduos esse problema se torna evidente, porque não é possível se identificar a origem de seu fabricante, importador, comerciante ou distribuidor.

Além disso, as estratégias de redução da poluição e dos resíduos não devem ser vistas como mera imputação de custos ao sistema produtivo. Há um grande incentivo a essa atuação sustentável tanto pela melhoria do meio ambiente como por aspectos sociais. Ainda é possível que haja a redução de custos das empresas. Um exemplo, dessa última situação, é a reinserção dos resíduos no ciclo produtivo, pois pode resultar em custos mais reduzidos com matérias-primas e com a minimização dos efeitos das obrigações de disposição final de rejeitos.

Um caso permite identificar a situação acima descrita. A DuPont, entre os anos de 1990 e 1995 estima ter gastado cerca de cinco milhões de dólares com o cumprimento de normas ambientais que impõe obrigações relativas ao descarte de resíduos. Mas em contrapartida houve uma redução de quarenta e cinco milhões de dólares com a redução de custos com materiais. A prevenção da poluição gerou um evidente benefício econômico. A comercialização de produtos reciclados movimentou 100 milhões de dólares. Isso possibilitou também a melhoria das condições de vida dos trabalhadores da empresa. Esse é um exemplo que permite se aferir a obtenção de melhores resultados econômicos mediante a atuação mais sustentável em prol do meio ambiente e da redução de resíduos ${ }^{210}$. Como já mencionado a PNRS prevê o instrumento da logística reversa, o qual pode ser utilizado como um mecanismo de estratégia competitiva, visto que pode possibilitar a redução de custos da produção, o melhor destino para estoques não vendidos e o aumento de matérias-primas secundárias. Isso dependerá muito de cada setor, mas, de maneira geral, pode se verificar incentivos ao setor econômico. ANA CÂNDIDA DE PAULA RIBEIRO E ARRUDA CAMPOS diz:

"Os resultados obtidos em função dos investimentos realizados pelos empresários são por demais satisfatórios. Aliás, uma boa política de gestão dos recursos naturais consegue transformar em receita o que até então não passava de subproduto (...). Resta patente que a implantação do sistema de gestão ambiental gera

${ }^{210}$ Para um maior aprofundamento do tema, confira-se: HART, Stuart L. O capitalismo na encruzilhada. As inúmeras oportunidades de negócios na solução dos problemas mais difíceis do mundo, 2006, p. 85. 
retorno para quem a tem utilizado, na medida em que elimina desperdícios e provoca ganhos na competitividade (...). É perfeitamente possível o desenvolvimento econômico sem que haja prejuízo ao meio ambiente ${ }^{211}$,.

Evidentemente que haverá gastos que, em alguns casos, serão vultosos, mas o retorno financeiro que se tem posteriormente acaba por compensar esses investimentos. $\mathrm{O}$ ganho ambiental também deve ser contabilizado, visto que permite a manutenção da qualidade de vida humana. Essa situação não se verifica se logística reversa for mal estruturada, caso em que poderá acarretar em gastos significativos, que não serão compensados.

${ }^{211}$ O desenvolvimento sustentável como diretriz da atividade econômica, 2002, p.86. 


\section{CAPÍTULO 3 - DA IMPLEMENTAÇÃO DA POLÍTICA NACIONAL DE RESÍDUOS SÓLIDOS URBANOS: A LOGÍSTICA REVERSA E A CONSENSUALIDADE}

\subsection{A operacionalização da gestão dos resíduos via logística reversa}

A logística reversa é imposta, sobretudo ante a escassez de matérias-primas, da ausência de espaços físicos para disposição final em aterros, assim como pela insuficiência do sistema produtivo em manter uma relação sustentável com meio ambiente ${ }^{212}$. Diante desse cenário, a manutenção do modo de operacionalização dos resíduos torna-se problemática. Como decorrência impõem-se novos padrões de produção e inclusive novos padrões de competitividade entre as empresas.

A logística reversa é um instrumento que visa a permitir a (i) redução da utilização de matéria-prima in natura, no caso aquela diretamente extraída do meio ambiente, (ii) a redução da quantidade de resíduos encaminhados aos aterros e também (iii) permitir uma reformulação do modo produtivo, incentivando ações de prevenção à geração de resíduos ${ }^{213}$.

A logística reversa funciona como um sistema circular em que existem fases distintas (como coleta, armazenagem, transporte, reaproveitamento, reciclagem), mas que são concatenadas e vão se sucedendo no tempo, com maior ou menor periodicidade, para a reintegração dos resíduos na cadeia produtiva e também para a redução dos fluxos desses resíduos. É, portanto, um processo contínuo/cíclico visto que uma fase é o ponto de origem de outra fase e, diferentemente, de um sistema linear as fases não conduzem a um ponto

\footnotetext{
212 DONALD F. BLUMBERG associa o surgimento da logística reversa a estudos desenvolvidos nas décadas de 60 e 70, nas áreas militar e de computação eletrônica, que visavam a identificar custos dos serviços. Tais estudos apontaram que grande parte dos gastos era relacionada ao fim da vida útil dos produtos. Em decorrência da busca da redução de custos foram desenvolvidas novas tecnologias e novos designs dos produtos. Iniciando-se, assim, a tomada de consciência sobre o valor do gerenciamento da cadeia produtiva associada ao reaproveitamento de resíduos. Essa concepção foi rapidamente transferida aos campos industrial e comercial. (Introduction to management of reverse logistics and closed loop supply chain processes, 2005, p. 38-41).

${ }^{213}$ A gestão de resíduos envolve tanto a geração de resíduos como a produção de bens e produtos, visto que esta última é um pressuposto do surgimento dos resíduos. A gestão adequada dos resíduos sólidos repercute na prevenção da geração de resíduos. Para alguns autores essa redução dos resíduos pode se dar mediante o aumento dos custos de produção, como a imposição de exigências mais rigorosas para a eliminação dos resíduos. Nesse sentido, confira-se: FÉRNANDEZ RAMOS, S., La política comunitária sobre resíduos: aspectos jurídicos generales, 1993, p. 130-132.
} 
final (onde o resíduo resta sem qualquer tratamento), mas à origem do sistema produtivo $^{214}$.

Há um sistema cíclico ${ }^{215}$, porque se reputa que a introdução do resíduo na cadeia produtiva se inicia com o reprocessamento ou com a reutilização, o que envolve até uma etapa anterior, que é a de coleta. Entende-se que, independentemente, de haver ou não remanufatura, reciclagem, o reaproveitamento dos resíduos possibilita o fechamento do ciclo produtivo $^{216}$.

Mas até os dias atuais é comum se verificar a disposição irregular de resíduos, em córregos, mananciais, em lixões sem o devido aproveitamento. Ou seja, verifica-se um sistema linear, visto que o resíduo não é valorizado e nem reinserido no ciclo produtivo.

\subsubsection{Contrapontos entre logística direta e logística reversa}

Para se conceituar logística reversa, tradicionalmente, costuma iniciar-se pela comparação ao conceito de logística, também denominada de logística direta, que consiste num processo de planejamento para a distribuição ou armazenamento de produtos, gerenciamento da aquisição de matéria-prima ou até mesmo como facilitador do transporte de produtos no âmbito interno de uma mesma empresa. É uma fase que possibilita a venda e a comercialização de produtos, tendo, usualmente, como ponto final, portanto, o consumo.

A logística reversa, como o próprio nome sugere, tem sido invocada como o caminho inverso no qual os resíduos são geridos até retornarem à cadeia produtiva ${ }^{217}$. A

\footnotetext{
${ }^{214}$ GARCÍA, José Francisco Alenza. El sistema de la gestión de resíduos sólidos urbanos en el derecho español, 1997, p. 187-188.

${ }^{215}$ Nesse sentido confira-se: ROGERS, Dale; TIBBEN-LEMBKE, Ron. Going Backwards: Reverse Logistics Trends and Practices, 1999, p. 188-191; POCHAMPALLY, Kishore K.; NUKALA, Satish; GUPTA, Surendra M. Strategic planning models for reverse and closed-loop supply chains, 2008, p. 1117 e LEITE, Paulo Roberto. Logística reversa. Meio ambiente e competitividade. 2. ed., 2009, p. 122-123.

${ }^{216}$ Para JOSÉ FRANCISCO ALENZA GARCÍA mesmo o modelo de reinserção do resíduo na cadeia produtiva, tido como cíclico, não o é verdadeiramente, porque o resíduo é reciclado e volta ao início da cadeia convertido em novo produto e este só possibilita o desenvolvimento das fases do ciclo quando se gera um resíduo, que será um novo resíduo e não mais aquele que foi originalmente descartado. Esse autor reputa que apenas a reutilização configura um autêntico ciclo, porque não implica a transformação do resíduo. A seu ver, seria melhor falar-se em ciclo dos produtos. (El sistema de la gestión de resíduos sólidos urbanos en el derecho español, 1997, p. 190-193). A divergência de posicionamentos parece ser mais terminológica, porque a valorização do resíduo e o seu reaproveitamento no ciclo produtivo ocorre independentemente da classificação linear proposta por JOSÉ FRANCISCO ALENZA GARCÍA. Reputa-se que a opção pela terminologia "linear" não seja a mais adequada, porque gera confusão com o sistema no qual os resíduos não são objeto de tratamento e, quando muito, apenas de disposição final.

${ }^{217}$ Nesse sentido, confira-se: “A logística reversa, por sua vez, representa um fluxo reverso da logística, ou seja, se a logística tradicional tem como missão distribuir produto novo para seus clientes, a logística reversa coletará os produtos considerados velhos, obsoletos, danificados, ou inúteis e os movimentará de
} 
logística reversa tem o seu ciclo se iniciando, em regra, a partir do consumidor e não do produtor como no caso da logística direta. Embora, em alguns casos, os produtos e bens passem pelo processo da logística reversa sem necessariamente terem sido consumidos, como no caso de produtos que estão fora do prazo de validade, que apresentem defeitos de fabricação ou excessos de estoques.

Há alguns pontos semelhantes entre as atividades de logística reversa e direta, porque ambas envolvem o transporte, o armazenamento e a gestão de processos, mas a operacionalização se dá de modo distinto. Além disso, e como já mencionado, a logística reversa envolve uma reformulação do sistema produtivo para gerar produtos mais sustentáveis e em menor escala.

Por um lado, a comparação com a logística direta facilita a compreensão de retorno dos resíduos ao início do ciclo produtivo, na medida em que o termo "reverso" indicaria o retorno de bens que foram consumidos, no caso os resíduos. Mas, por outro lado, é preciso se atentar que a real dimensão da logística reversa é um processo muito mais complexo do que o mero retorno dos produtos descartados pelos consumidores a uma cadeia produtiva $^{218}$. Além disso, o reaproveitamento ou a reinserção dos resíduos pode se dar em cadeia distinta da qual se originou.

A logística reversa aplicável dependerá muito do tipo de resíduo, de suas características físicas e químicas e de sua qualidade. Não há um processo uniforme. Ou seja, cada segmento produtivo terá de estabelecer qual a melhor maneira de gerenciar essa atividade, devido às peculiaridades de cada tipo de resíduo. Essa particularidade difere a logística “reversa” da logística direta, isso porque esta última apresenta, de modo geral, uma homogeneidade de sistematização aplicável a grande parte dos produtos, variando, conforme o caso, o modal a ser utilizado e algumas estratégias de gestão de processos.

A analogia à figura da subsidiária integral ${ }^{219}$ exemplifica bem a existência de toda uma gama de atividades, que a diferem da logística direta. Isso porque a subsidiária

modo a fornecer disposição final ou tratamento adequado, que pode ser a reciclagem, a reutilização, a remanufatura, cooprocessamento, etc”. (VAZ, Letícia, Educação ambiental e logística reversa, 2012).

${ }^{218}$ Para ROGÉRIO VALLE e RICARDO SOUZA GABBAY a logística reversa “(...) envolve intensamente outras funções: produção, marketing, recursos humanos, desenvolvimento de produtos, análise financeira, contratos e parcerias etc. Essencialmente, ela acaba por se tornar uma miniatura da empresa dentro da própria empresa, em constante comunicação com esta. Gerenciar a logística reversa nas organizações equivale, portanto, a gerenciar uma nova empresa, uma subsidiária” (Logística reversa. Processo a processo, 2014, p. 2).

${ }^{219}$ ROGÉRIO VALLE e RICARDO SOUZA GABBAY ao formularem essa comparação com a figura da subsidiária, utilizam o termo subsidiária no sentido de criar-se uma empresa dentro da própria empresa. Assim cabe ressalvar que se alude à figura da subsidiária integral. Nos termos do art. 251 da Lei 6.404/1976 a subsidiária integral é a companhia integrada por um único sócio. A ressalva é oportuna, pois a subsidiária 
integral, via de regra, é criada para diversificação das atividades da empresa, que exigem especialização diferenciada. A subsidiária integral tem por função auxiliar as atividades desenvolvidas pela empresa principal. A atividade da logística reversa pode ser vista como acessória à atividade produtiva, no sentido de que possibilita a obtenção de modo alternativo de matéria-prima. Além disso, a sincronização entre a logística direta e a logística reversa é bastante relevante para uma gestão eficiente da cadeia logística considerada como um todo 220 .

Mas ainda assim deve se ter cautela com essa comparação, porque a logística reversa também pode modificar o modo como se desenvolverá a atividade principal ${ }^{221}$. Ou seja, o modo de produção, o design e o tipo de material empregado na produção, o marketing, o grau de estímulo, maior ou menor, ao consumo etc, em razão das exigências de prevenção aos resíduos.

\subsubsection{Delimitação conceitual tradicional da logística reversa: ressalva prévia}

A delimitação conceitual do termo logística reversa é uma tarefa bastante complexa e que exige um constante aperfeiçoamento. Em primeiro lugar porque a logística reversa está, em grande medida, vinculada ao modo de organização das estruturas produtiva, cuja gestão e operacionalização empresarial são sempre bastante dinâmicas. Em segundo lugar, pois os bens e produtos produzidos possuem diferentes características de composição, estruturação, toxidade etc. Assim, há uma dificuldade de se estabelecer uma conceituação que abarque todas as especificidades dos diferentes tipos de resíduos em um único conceito.

As soluções de logística reversa adotadas na cadeia de equipamentos eletrônicos, por exemplo, certamente não serão exatamente as mesmas aplicáveis à gestão de embalagens ou medicamentos, em razão do tamanho, peso, volume, toxidade, estrutura de componentes etc. No entanto, isso não quer dizer que não possam ser indicados alguns aspectos comuns na logística reversa dos diversos segmentos produtivos. Mas observe-se que tal conceituação nunca será totalmente satisfatória, porque dificilmente abarcará todas as peculiaridades que envolvem o tema dos resíduos.

pode ser constituída por outros sócios, o que descaracterizaria o exemplo acima pretendido. (Logística reversa. Processo a processo, 2014, p. 2).

${ }^{220}$ POCHAMPALLY, Kishore K.; NUKALA, Satish; GUPTA, Surendra M. Strategic planning models for reverse and closed-loop supply chains, 2008, p. 16.

${ }^{221}$ Não se exclui a possibilidade da empresa optar por terceirizar as atividades que tenham de ser desenvolvidas. No entanto, devem ser mantidas as responsabilidades que lhe são impostas pela lei ou por atos regulamentares. 


\subsubsection{O conceito de logística reversa}

É difícil precisar-se um marco exato de surgimento do termo logística reversa, mas identificam-se os primeiros estudos acadêmicos a partir dos anos setenta ${ }^{222}$. As conceituações iniciais envolviam, de maneira geral, a noção de retorno dos produtos, mas bastante vinculada à ideia reciclagem ${ }^{223}$ e não exatamente como um canal de distribuição reverso e muito menos vinculado à noção de organização produtiva e competitiva das empresas.

Posteriormente, o conceito foi se aprofundando e traçou-se, então, a ideia de fluxo contrário ao da cadeia direta de suprimentos, no caso da logística direta ${ }^{224}$, envolvendo processos de reuso, remanufatura e reciclagem, mas caracterizando um conjunto de atividades mais complexo.

De modo geral, e como destaca OLAF SCHATTEMAN, a logística passou, tradicionalmente, a ser definida como um processo de movimentação do produto do ponto de consumo até o ponto de produção com o objetivo de recapturar valor ou proceder-se a eliminação adequada. Incluindo-se no conceito de logística reversa também atividades que visem a reduzir a quantidade de materiais produzidos e a garantir a possível reutilização e reciclagem de materiais ${ }^{225}$.

Essa concepção é adotada por diversos autores e foi originalmente proposta por DALE ROGERS e RON TIBBEN-LEMBKE. Esses autores, partindo da definição de logística direta do Conselho de Gestão Logística - The Council of Logistics Management, conceituaram a logística reversa como um processo que envolve "o planejamento, $a$ implementação e o controle eficiente do custo do fluxo de matérias-primas, estoques, produtos acabados e informações relacionadas ao deslocamento do ponto de consumo até o ponto de origem para recuperação de valor ou para a disposição final ${ }^{226 ”, ~(t r a d u c ̧ a ̃ o ~}$ livre). A logística reversa, na visão desses autores, portanto, altera o fluxo de bens da

\footnotetext{
${ }^{222}$ Na tese de doutoramento de MARISA P. DE BRITO, desenvolvida na Universidade de Erasmus Rotterdam, há um apanhado histórico bastante interessante das principais conceituações de logística reversa. (Managing reverse logistics or reversing logistics management?, 2003, p. 21. Disponível em: http://repub.eur.nl/pub/1132/. Acesso em 11.11.2014).

${ }^{223}$ Nesse sentido, confira-se: GUILTINAN, Joseph; NWOKOYE, Nonyelu. Reverse channels for recycling: an analysis for alternatives and public policy implications. In: CURHAN, R. G. (Editor). New marketing for social and economic progress. Combined Proceedings, 1974.

${ }^{224}$ Adiante irá tratar-se da diferenciação entre a logística reversa e as outras modalidades de logística.

${ }^{225}$ Reverse logistics. In: GATTORNA, John (Coord.). Gower handbook of supply chain management. 5. ed., 2008, p. 267.

${ }^{226}$ Confira-se o conceito original: "The process of planning, implementing, and controlling the efficient, cost effective flow of raw materials, in-process inventory, finished goods and related information from the point of consumption to the point of origin for the purpose of recapturing value or proper disposal". (Going Backwards: Reverse Logistics Trends and Practices, 1999, p. 2).
} 
disposição final típica com o objetivo de capturar valor ou de se atribuir uma destinação final adequada.

Nesse mesmo sentido, para CURTIS GREVE e JERRY DAVIS a logística reversa pode ser definida como um processo que, ao invés de encaminhar os bens à destinação final tradicional, opta pela captura de valor e de eliminação adequada ${ }^{227}$. Esses autores destacam que a logística reversa é muito mais do que o simples retorno dos bens do consumidor. Isso porque ela envolve um processo mais complexo de reciclagem, gestão da disposição final, recalls, processos de reparação, dentre outros procedimentos ${ }^{228}$. Os autores ainda definem a logística reversa como uma rede sustentada por três pilares fundamentais: (i) divulgação das políticas de retorno das empresas; (ii) a qualidade do programa de logística reversa e (iii) parcerias entre os fornecedores.

MORITZ FLEISCHMANN propõe o seguinte conceito de logística reversa: “é o processo de planejamento, implementação e controle eficiente, efetivo do fluxo e armazenamento de bens secundários e informações relacionadas à tradicional direção da cadeia produtiva para obter-se valorização econômica ou a disposição adequada ${ }^{229, " . ~}$

\subsubsection{Algumas reflexões sobre a concepção tradicional de logística reversa}

Os conceitos acima apresentados destacam que a logística envolve uma gama diversificada de atividades, como planejamento e operacionalização do fluxo de retorno dos bens e produtos, além da valorização dos resíduos. Desse modo, não é suficiente compreendê-la como o mero retorno dos bens e produtos que foram descartados. Há uma série de atividades a serem desenvolvidas para a efetivação da logística reversa.

Mas é necessário notar que o conceito de DALE ROGERS e RON TIBBEN-

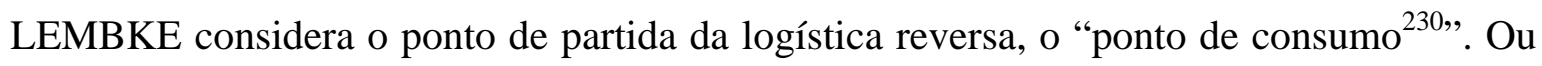

\footnotetext{
${ }^{227}$ Executive's guide to reverse logistics: how to find hidden profits by managing returns, 2012, p. 35.

${ }^{228}$ GREVE, Curtis; DAVIS, Jerry. Reverse Logistics. Recovering lost profits by improving, 2012, p. 4.

${ }^{229}$ Confira-se o conceito original: "Reverse Logistics is the process of planning, implementing, and controlling the efficient, effective inbound flow and storage of secondary goods and related information opposite to the traditional supply chain direction for the purpose of recovering value or proper disposal". (Quantitative model for reverse Logistics, 2000, p. 21).

${ }^{230}$ DALE ROGERS e RON TIBBEN-LEMBKE enfatizam que o ponto de retorno dos produtos pode ser tanto proveniente de um usuário final ou de outro agente integrante do canal de distribuição, como comerciantes. (Going Backwards: Reverse Logistics Trends and Practices, 1999, p. 12). Note-se que essa noção não se compatibiliza com o consumo em seu sentido econômico, ou seja, no qual o consumidor adquire bens e produtos como destinatário final e não para o desenvolvimento de outra atividade negocial, que é o conceito abrangido pelo Código de Direito do Consumidor brasileiro. Nesse sentido, confira-se: GRINOVER, Ada Pellegrini; VASCONCELLOS, Antônio Herman de; FINK, Daniel Roberto; FILOMENO, José Geraldo Brito; WATANABE, Kazuo; NERY JUNIOR, Nelson; DENANI, Zelmo. Código Brasileiro de Defesa do Consumidor comentado pelos autores do anteprojeto. 8. ed., 2004, p. 27.
} 
seja, pressupõe um descarte decorrente do consumo. Mas ao indicar "matérias-primas, estoques e produtos acabados”, esse conceito ignora ressalva de que não necessariamente o consumo será a fase antecedente da logística reversa.

No caso de excesso de estoques o produto não chega a ser comercializado e, portanto, não é consumido. Ignora-se também sobras do processo produtivo, produtos que não foram consumidos - seja por defeitos de fabricação, de armazenamento ou transporte produtos cujo prazo de validade está expirado, dentre outros fatores ${ }^{231}$, porque em tais casos também não há o consumo prévio.

Além disso, os produtos não retornam necessariamente ao ponto de origem, podendo ser reintegrados a outros ciclos produtivos ou a um mercado secundário. Nesse ponto o conceito proposto por MORITZ FLEISCHMANN não alude a ponto de origem, mas apenas a fluxo de bens secundários. O conceito, ao não mencionar “produtos” e sim “bens secundários”, incorpora uma noção de que os bens não são os mesmos que foram originalmente produzidos.

As formulações prestam grande contribuição à matéria com a incorporação da acepção de valorização dos bens ${ }^{232}$ e também acerca da necessidade de se adotar uma destinação final adequada, mas nenhum desses autores inclui a prevenção de resíduos como uma característica da logística reversa ${ }^{233}$.

${ }^{231}$ Como identificam ROMMERT DEKKER e MARISA P. DE BRITO o conceito de DALE ROGERS e RON TIBBEN-LEMBKE reflete uma definição essencial do que seja a logística reversa. No entanto, eles criticam algumas generalizações. A menção ao termo "ponto de consumo", visto que ignora a possibilidade de outras fontes originárias de resíduos, tais como aqueles produtos que perderam a validade, sobras do processo produtivo, produtos danificados, problemas de estoques, produtos cujo prazo de garantia esgotou-se, políticas de marketing, etc. Esses autores ainda sustentam a possibilidade de os produtos recuperados serem encaminhados para outros pontos da cadeia produtiva que não o ponto de origem, como peças de computadores que podem ser incorporadas em outras cadeias. (A Framework for reverse logistics, 2003, p. 3).

${ }^{232}$ O valor agregado além de atribuir uma valoração econômica ao resíduo poderá também agregar valores: logísticos, de imagem à empresa, ambientais, sociais e legais. Os valores logísticos referem-se ao melhor desempenho operacional e gerencial de toda a cadeia produtiva, com a redução de custos e o aumento da eficiência produtiva. Os valores de imagem da empresa se relacionam à satisfação dos clientes com as boas práticas ambientais. Os valores ambientais relacionam-se ao fato de os diversos métodos de reparo, reuso, reciclagem, recuperação possibilitarem a redução do consumo de recursos naturais e também de rejeitos encaminhados para disposição final, o que reduz a necessidade de espaços físicos para construção de aterros ou usinas de incineração. Os valores sociais podem referir-se, desde a inclusão de catadores, pequenas cooperativas de reciclagem nas atividades de logística reversa, até mesmo a ganhos de saúde pública com redução de doenças causadas por vetores que se proliferam em meio aos rejeitos ou resíduos dispostos de modo irregular. Os valores legais são no sentido de cumprimento das políticas públicas delineadas em lei, tal como a PNRS. (MENDONÇA, Fabrício Molica de; PONTES, André Teixeira; SOUZA, Ricardo Gabbay de. Logística reversa, Meio Ambiente e Sociedade, 2014, p. 8 e 10).

${ }^{233}$ Going Backwards: Reverse Logistics Trends and Practices, 1999, p. 2. 
Uma das conceituações mais completas sobre a logística reversa é a formulada por LOURENÇO COSTA, FABRÍCIO MOLICA DE MENDONÇA E RICARDO DE GABBAY, confira-se:

"A logística reversa é o processo de recuperação dos resíduos de pós-venda ou pós-consumo, pela coleta, prétratamento, beneficiamento e distribuição, de forma a ou retorná-los à cadeia produtiva, ou dar-lhes destinação final adequada (sic) $)^{234}$. Deve enfocar a minimização dos rejeitos $^{235}$ e dos impactos negativos e a maximização dos impactos positivos, sejam ambientais, sociais ou econômicos. Este processo incorpora as atividades operacionais, de gestão e de apoio que, de forma integrada e envolvendo os diversos atores, planejem e viabilizem a implementação das soluções mais adequadas para os resíduos ${ }^{236,}$.

O conceito acima descrito é bastante completo, porque enfatiza a logística por diversos prismas, ou seja, há uma preocupação com aspectos ambientais, mas também sociais e econômicos. Identifica-se que a logística é um procedimento que permite a realização de diversas atividades (como a coleta, o reuso, o tratamento e o beneficiamento) com vistas ao reaproveitamento dos resíduos na cadeia produtiva e à prevenção de resíduos. Também se reconhece a existência de diversos atores para a sua implementação. Assim como, aspectos inerentes à concepção logística, como gestão, planejamento e operacionalização das atividades.

\subsection{A caracterização da logística reversa pelo momento do descarte}

As empresas que coletam os resíduos raramente sabem quando os produtos foram comprados e por qual motivo eles foram descartados ${ }^{237}$. Mas para as empresas que os produzem é importante identificar as razões que circundam o descarte, porque isso influencia na gestão e operacionalização dos negócios.

\footnotetext{
${ }^{234}$ Os autores possivelmente pretendiam referir-se à disposição final adequada e não propriamente à destinação final.

${ }^{235}$ É necessário minimizar o número de resíduos que são tratados como rejeitos e também reduzir a produção de rejeitos. Note-se que são atividades correlatas, no entanto distintas, porque no primeiro caso tem-se a exigência de destinação adequada dos resíduos e na segunda hipótese exige-se um processo mais complexo, porque se necessita de modificações na estrutura produtiva, que possibilite, então, a redução da produção de rejeitos.

${ }^{236}$ O que é Logística reversa, 2014, p. 27.

${ }^{237}$ POCHAMPALLY, Kishore K.; NUKALA, Satish; GUPTA, Surendra M. Strategic planning models for reverse and closed-loop supply chains, 2008, p. 15.
} 
O descarte de resíduos pode envolver elementos objetivos, como quando o bem ou produto perdeu a funcionalidade inicialmente prevista ou quando decorre de uma exigência legal. Assim como aspectos subjetivos, o que se dá por mera opção do seu detentor $^{238}$, visto que pode não envolver a inutilidade do bem ou produto que será descartado, podendo decorrer apenas de uma escolha pessoal, subjetiva ${ }^{239}$. É evidente que mesmo na primeira situação existe uma tomada de decisão subjetiva, optando-se pelo descarte, no entanto, essa opção decorre muito mais de uma necessidade do que uma vontade em si, porque o bem já não é dotado de funcionalidade ${ }^{240}$. Em qualquer caso, o descarte de resíduos pode se dar pela eliminação adequada ou pelo simples abandono do resíduo $^{241-242}$. É possível que tanto na fase de produção como de consumo ocorra o descarte de bens e produtos.

\subsubsection{Pós-venda}

A logística reversa pode se dar no pós-venda, que corresponde ao descarte oriundo a uma fase anterior ao consumo: produtos com defeitos, defeitos decorrentes do transporte, excesso de estoques, estoques obsoletos.

\footnotetext{
${ }^{238}$ Existe alguma controvérsia, no direito europeu, sobre a qualificação atribuível a aquele que descartar resíduos, porque a depender da classificação adotada poder-se-ia optar por um regime jurídico diferenciado, caso fosse enquadrado como propriedade, detenção ou posse. O aprofundamento do tema escapa ao objeto do presente trabalho, pelo que se recomenda a seguinte obra: GARCÍA-ALCALÁ, Calixto Díaz-Regañón. El régimen jurídico-privado de los resíduos, 1998, p. 70-80.

${ }^{239}$ Essa opção, muitas vezes, é influenciada por estratégias de marketing e publicidade, que estimulam, em grande medida, o descarte, cada vez mais rápido, de bens de consumo. Sobre o tema, confira-se: WIND, Yoram. Models for Marketing planning and decision making, 1985.

${ }^{240}$ Para JOSÉ FRANCISCO ALENZA GARCÍA o elemento subjetivo envolve tanto a vontade de descarte como o descarte motivado pela ausência de utilidade do bem e o elemento objetivo trata da previsão legal de desfazimento do produto, que deve levar em conta o interesse público em causa, seja a proteção da saúde, questões ambientais etc. (El sistema de la gestión de resíduos sólidos urbanos en el derecho español, 1997, p. 143).

${ }^{241}$ ALEXANDRA ARAGÃO enfatiza duas interpretações para a ideia de "desfazer-se” de um produto ou material, sendo a primeira uma acepção subjetiva, na qual o detentor apenas abandona os resíduos, o que é, segundo a legislação portuguesa, uma situação ilegal. A segunda acepção é objetiva e corresponde a alterar a destinação de alguma coisa, podendo corresponder tanto a valorização como a intenção de eliminar resíduos. (Os resíduos e a sua gestão internacional, 2006, p. 278).

${ }^{242}$ Note-se que o abandono de resíduos, de acordo com a legislação brasileira, pode configurar crime ou ensejar a responsabilização civil e criminal. No tocante aos resíduos perigosos, a Lei 9.605/1998, com redação dada pela Lei 12.305/2010, no art. 56, tipifica o crime de abandono de resíduos perigosos. A Lei 6.938/1981 responsabiliza aqueles que poluírem o meio ambiente (art. $3^{\circ}$, inc. IV e art. 14 , $\S 1^{\circ}$ ). Desse modo, o simples abandono quando ensejar algum dano poderá ensejar a responsabilização daquele que o causar. No entanto, esse entendimento não é uníssono, na doutrina espanhola, por exemplo, há quem repute que o abandono de resíduos só poderá ensejar a responsabilização quando houver causado algum dano, por se compreender que o objetivo da legislação é a proteção ambiental e a saúde pública. Assim não sendo verificado dano, não há a violação que seja apta a ensejar a imputação do dano. Sobre o tema confira-se: SÁNCHEZ SÁEZ, Antonio José. Otro paso a oscuras en la necesaria delimitación conceptual del abandono de residuos: la Sentencia 496/2.003, de 14 de mayo, de la Sala de lo ContenciosoAdministrativo del Tribunal Superior de Justicia de Galicia).
} 
É possível ainda que os produtos na fase do pós-venda decorram de erros de pedido $^{243}$ ou ainda por decorrência de garantias legais, como a prevista no art. 49 do Código de Defesa do Consumidor brasileiro: “O consumidor pode desistir do contrato, no prazo de sete dias a contar de sua assinatura ou do ato de recebimento do produto ou serviço, sempre que a contratação de fornecimento de produtos e serviços ocorrer fora do estabelecimento comercial, especialmente por telefone ou a domicílio".

A logística reversa de pós-venda pode envolver o retorno por razões diferenciadas, mas o que a identifica é o fluxo de retorno de bens com pouco uso ou não utilizados ${ }^{244}$.

\subsubsection{Pós-consumo}

O pós-consumo é a fase na qual os resíduos foram consumidos e estão no fim da vida útil, podendo ser encaminhados para o reuso ou para processos de transformação ${ }^{245}$. O principal objetivo da logística reversa na fase de pós-consumo é agregar valor a bens que já se encontram no fim da vida útil e àqueles que ainda possam ser passíveis de reutilização ${ }^{246}$.

PAULO ROBERTO LEITE destaca que:

"Os canais reversos de pós-consumo constituem-se nos diferentes modos de retorno dos produtos após seu uso, podendo apresentar serventia a novos possuidores, caracterizando-se os canais de reúso (sic), dos bens de pósconsumo, ou não apresentando condições de reutilização, sendo destinados aos canais reversos de reciclagem de produtos ou de seus materiais constituintes ${ }^{247}$,"

\subsection{A diferenciação entre logística reversa e o gerenciamento de resíduos sólidos}

A logística reversa difere do gerenciamento de resíduos, porque esse último engloba também a disposição final, como incineração e encaminhamento de rejeitos a aterros sanitários. Já a logística reversa envolve apenas os métodos de destinação final e de prevenção de resíduos. Desse modo, pode-se dizer que os rejeitos não são uma

\footnotetext{
${ }^{243}$ LEITE, Paulo Roberto. Logística Reversa. Meio ambiente e competitividade. 2. ed., 2009, p. 10.

${ }^{244}$ LEITE, Paulo Roberto. Logística Reversa. Meio ambiente e competitividade. 2. ed., 2009, p. 18.

${ }^{245}$ GUARNIERI, Patrícia. Logística Reversa. Em busca do equilíbrio econômico e ambiental, 2011, p. 55.

${ }^{246}$ LEITE, Paulo Roberto. Logística Reversa. Meio ambiente e competitividade. 2. ed., 2009, p. 19.

${ }^{247}$ Logística Reversa. Meio ambiente e competitividade. 2. ed., 2009, p. 77.
} 
preocupação direta da logística reversa, visto que não são diretamente reinseridos na cadeia produtiva $^{248}$.

\subsection{Logística reversa de ciclo fechado}

O reaproveitamento dos resíduos pode se dar no âmbito da mesma cadeia produtiva. Alude-se, neste caso, ao circuito fechado ou ao ciclo fechado cadeia de suprimentos (closed-loop).

Ou seja, após o descarte dos resíduos ou até mesmo antes, quando da verificação de algum problema que impossibilite a venda, possibilita-se a destinação do resíduo na mesma cadeia em que se originou. O retorno é feito diretamente ao gerador do resíduo ${ }^{249}$ ou a empresa terceirizada, quando o caso. Por tal razão, alude-se à cadeia fechada. Mas o modo de fechamento do ciclo e a logística reversa das cadeias produtivas não serão os mesmos para todos os tipos de resíduos, porque cada qual possui especificidades ${ }^{250}$.

Um exemplo bastante referenciado na literatura estrangeira do tema ora analisado é o caso Kodak. Nos anos noventa, a Kodak criou um programa de reuso das câmeras fotográficas que possibilitava o fechamento do ciclo produtivo. O primeiro estágio do fechamento do ciclo produtivo iniciou-se com a reformulação do design da câmera. Isso para que fosse possível reutilizar determinados componentes. Estima-se que cerca de 70 a 80\% das câmeras descartadas eram recicladas. O segundo estágio do fechamento do ciclo produtivo relacionava-se ao retorno pós-consumo das câmeras. As taxas de retorno também eram bastante significativas, em torno de 70\% nos Estados Unidos e 60\% em outros vinte países. A facilidade para desmontar as partes recicláveis e reutilizáveis das demais partes auxiliava muito a eficiência do fechamento da cadeia ${ }^{251}$.

\subsubsection{Logística reversa de ciclo aberto}

Mas a logística reversa também pode se dar em circuito aberto. Ou seja, o reaproveitamento do resíduo se dá em outra cadeia produtiva ${ }^{252-253}$.

\footnotetext{
${ }^{248}$ DEKKER, Rommert; DE BRITO, Marisa P.;. A framework for reverse logistics, 2003, p. 3.

${ }^{249}$ SOUZA, Marcelle Rodrigues de; SOUZA, Ricardo Gabbay de. Destinação final, 2014, p. 154.

${ }^{250}$ Sobre o tema confira-se: GUIDE, V. Daniel R.; WASSENHOVE, Luk N. Van. Closed-loop supply chains, 2002, p. 47-60.

${ }^{251}$ GUIDE, V. Daniel R.; WASSENHOVE, Luk N. Van. Closed-loop supply chains, 2002, p. 47-49.

${ }^{252}$ SOUZA, Marcelle Rodrigues de; SOUZA, Ricardo Gabbay de. Destinação final, 2014, p. 154.

${ }^{253}$ COSTA, Lourenço; MENDONÇA, Fabrício Molica de; SOUZA, Ricardo Gabbay de. O que é Logística reversa, 2014, p. 30.
} 
O alumínio, por exemplo, é um material que pode ser reciclado e inserido em outras cadeias produtivas diferentes daquele em que estava originalmente empregado. $\mathrm{O}$ alumínio é utilizado em uma gama bastante diversificada de atividades, como para fabricação de utensílios domésticos, em latas de bebidas, peças automotivas, dentre outras finalidades. Os produtos PET também podem ser reciclados por ciclo aberto. A partir da reciclagem é possível obter-se matéria-prima para a produção de cordas, vassouras, chapas para Box de banheiro, resinas, peças automotivas, caixas, tubos para esgotamento predial etc $^{254}$.

\subsection{Vedação ao emprego da logística reversa}

Em alguns casos, pode ser vedado, pela legislação ou em regulamentação, o reaproveitamento dos resíduos na categoria produtiva. Na área de resíduos da saúde, tais como materiais perfurocortantes, há vedação expressa na Resolução da Diretoria Colegiada - RDC/ANVISA 306/2004 ${ }^{255}$ ao reaproveitamento.

\subsection{Logística verde}

A logística reversa não se confunde com a chamada logística verde. Esse último termo remete a uma acepção ampla de logística, que pode envolver tanto o fluxo reverso como direto. A logística verde ${ }^{256}$ é muito mais do que uma forma de logística, refere-se ao nível de sustentabilidade da cadeia logística. O aumento da valorização das questões ambientais seja pela sociedade como pelos entes públicos refletiu na forma de gerenciamento da logística. A exigência de redução de impactos ambientais exige das empresas uma nova postura, o que se reflete nessa nova concepção da logística ${ }^{257}$. Mais precisamente, a logística verde é uma estratégia que visa a minimizar os impactos ambientais provocados pela logística por meio da implementação de estratégias ambientalmente adequadas.

254 Para maiores informações, consulte-se: http://www.abipet.org.br/index.html?method=mostrarInstitucional\&id=70. Acesso em 19.11.2014.

${ }^{255}$ Isso dependerá das características e das propriedades de cada resíduo e da compatibilidade com a cadeia produtiva a ser inserido. A Lei 6.360/1976, art. 64, veda “o reaproveitamento e a utilização de vasilhame tradicionalmente usado para alimentos, bebidas, refrigerantes, produtos dietéticos, medicamentos, drogas, produtos químicos, de higiene, cosméticos e perfumes no envasilhamento de saneantes e congêneres”. Nesse mesmo sentido dispõe a Resolução-RDC 59/2010, art. 28.

${ }^{256}$ Sobre o tema, confira-se: MCKINNON, Alan et. al. Green Logistics: Improving the Environmental Sustainability of Logistics. $2^{\text {nd }}, 2012$.

${ }^{257}$ MCKINNON, Alan et. al. Green Logistics: Improving the Environmental Sustainability of Logistics. $2^{\text {nd }}, 2012$, p. 3. 
Desse modo, por meio da logística verde "Busca-se a minimização dos ônus relacionados aos problemas ambientais”, o que envolve “(...) cinco frentes de trabalho: redução das externalidades dos transportes de cargas (...); - logística urbana (...); logística reversa (...); - estratégias ambientais organizacionais no sentido da logística (...); - gestão verde da cadeia de suprimentos ${ }^{258,}$.

A logística, seja direta ou reversa, está relacionada fortemente relacionada aos meios de transporte/canais de distribuição. A opção pelo modal (ou até de combinação entre modais) depende das características da região onde será realizado, da infraestrutura disponível e ainda do tipo de produto ou resíduo. Em regra, quando possível, a preferência por modais ferroviário, marítimo ou fluvial tende a produzir impactos menores no tocante à emissão de poluição, considerando a distância percorrida e a quantidade de material transportado. Assim como, também é possível reduzir os custos com transporte, na medida em que a modificação do modal utilizado pode aumentar a quantidade transportada ${ }^{259}$.

A Hidrovia Tietê-Paraná é um exemplo de atuação no sentido da logística verde. Segundo dados divulgados pela Antaq, o transporte de etanol feito por esse modal possibilitou a redução da emissão de poluentes, um menor custo logístico, aumento da capacidade de carga, maior segurança operacional e menor geração de resíduos. Outro exemplo é o Hidroanel Metropolitano de São Paulo, licitado em 2009, que consiste num canal de $170 \mathrm{~km}$ a ser implantado nos rios Tietê e Pinheiros, para facilitar o transporte de resíduos $^{260}$.

\subsection{O conceito jurídico de logística reversa}

A Política Nacional de Resíduos Sólidos, instituída pela Lei Federal 12.305, de 2 de agosto de 2010, aborda em seu art. $3^{\circ}$, inc. XII o mecanismo da logística reversa: “(...) instrumento de desenvolvimento econômico e social caracterizado por um conjunto de ações, procedimentos e meios destinados a viabilizar a coleta e a restituição dos resíduos sólidos ao setor empresarial, para reaproveitamento, em seu ciclo ou em outros ciclos produtivos, ou outra destinação final ambientalmente adequada”.

\footnotetext{
${ }^{258}$ COSTA, Lourenço; MENDONÇA, Fabrício Molica de; SOUZA, Ricardo Gabbay de, O que é Logística reversa, 2014, p. 21. Sobre o tema, confira-se também: MCKINNON, Alan et. al. Green Logistics: Improving the Environmental Sustainability of Logistics. $2^{\text {nd }}$, 2012, p. 5.

259 Dados disponíveis em: http://www.antaq.gov.br/portal/pdf/Palestras/IISeminarioPVN2011/Agenor20110922ApresentacaoAgenorC Dep2Seminario.pdf. Acesso em 19.11.2014.

${ }^{260}$ Sobre o tema, confira-se: http://www.metropolefluvial.fau.usp.br/hidroanel.php. Acesso em 19.11.2014.
} 
A logística reversa não foi criada pela Lei 12.305/2010, pois já havia outras resoluções e legislações estaduais ou municipais, que tratavam do assunto, como, por exemplo: Resoluções do CONAMA 307/2002 - gestão dos resíduos da construção civil, 401/2008 - gerenciamento de pilhas e baterias e 416/2009 - gestão de pneus inservíveis; Resolução SEMA/PR 057/2008 - proíbe o recebimento de pneus inservíveis de outros estados; Lei Estadual 12.493/1999 (Paraná) - procedimentos e normas sobre resíduos sólidos e a Lei Municipal 13.316/2002 (São Paulo) - gerenciamento de embalagens, garrafas plásticas e pneumáticos. Mas a Lei 12.305/2010 é a primeira legislação que trata da matéria no âmbito federal.

A relevância dos problemas gerados pelos resíduos impõe uma política nacional, de modo a sistematizar diretrizes e ações práticas em todo território nacional. No entanto, isso não quer dizer que o tema deixe de ser regulamentado por legislações específicas nos âmbitos estadual e municipal, pelo contrário, a lei prevê que a regulamentação dos resíduos se dê por todas as esferas federativas ${ }^{261}$.

\subsubsection{A restituição dos resíduos sólidos ao setor empresarial e o seu reaproveitamento no ciclo produtivo}

Na Lei 12.305/2010, prevê-se a noção de que os produtos e bens consumidos que tenham perdido alguma de suas qualidades originais ${ }^{262}$ (que impossibilitem a sua comercialização ou utilização) ou ainda bens que sejam simplesmente descartados não devem ser apenas encaminhados à disposição final. Assim, os resíduos passam a ser um insumo (ou como também se denomina, matéria-prima secundária) para o ciclo produtivo. Alguns procedimentos como a coleta seletiva, a reciclagem e a compostagem viabilizam essa reinserção dos resíduos na cadeia produtiva.

Os produtos que retornam aos fabricantes podem ter diferentes destinos. Aqueles resíduos que retornam da fase pós-consumo em razão do fim da vida útil dos produtos podem ser encaminhados para os processos como de reciclagem, remanufatura e recondicionamento. Se o resíduo retorna do pós-venda é possível revendê-lo e caso não possua qualidade suficiente para ser vendido pode-se encaminhá-lo ao reprocessamento.

As atividades de reaproveitamentos dos resíduos podem ser desenvolvidas diretamente pelos fabricantes ou ainda por terceirização.

\footnotetext{
${ }^{261} \mathrm{O}$ art. 16 da PNRS prevê a implantação de planos estaduais e o art. 18 os planos municipais.

${ }^{262}$ Tal situação pode ocorrer, por exemplo, em razão de algum defeito de fabricação ou por ter decorrido o prazo de validade.
} 


\subsubsection{A logística como instrumento de desenvolvimento econômico e social}

A logística reversa se volta ao desenvolvimento econômico e isso poderá se dar tanto para manutenção do atual modelo econômico como para estimular novas formas desse desenvolvimento.

A logística reversa se torna uma forma de potencializar a rentabilidade dos negócios, porque permite poupar-se a utilização de recursos naturais primários, além de reduzir a quantidade de energia utilizada no processo produtivo, possibilitando a redução de custos. Por essa razão muitas empresas já investiam nesse segmento antes da Lei $12.305 / 2010^{263}$.

O aspecto social também deve ser considerado pela logística reversa. A cadeia logística envolve diversas ações que possibilitam aumentar os postos de trabalho seja na fase de coleta, armazenagem ou reciclagem etc. A PNRS inclusive prevê estímulos para inclusão de pequenas recicladoras de catadores de papel ${ }^{264}$.

O desenvolvimento social também pode ser dar pela manutenção da qualidade de vida, uma vez que pode conter e até mesmo minimizar a geração de resíduos. A redução da utilização de espaços físicos para construção de aterros também possibilita a preservação de áreas verdes ou, quando possível, uma destinação alternativa para a construção, por exemplo, de habitações.

\subsubsection{A logística reversa como procedimento}

A logística reversa trata-se de um procedimento ${ }^{265}$. Ou seja, envolve diversas etapas que se relacionam e se sucedem, de modo que possibilitem o reaproveitamento dos componentes dotados de certa utilidade em algum segmento da cadeia produtiva.

\footnotetext{
263 Desde a década de 90 têm aumentado progressivamente os investimentos na área de logística reversa, justamente em função de uma visão estratégica dos negócios. (ROGERS, Dale; TIBBEN-LEMBKE, Ron. Going Backwards: Reverse Logistics Trends and Practices, 1999, p. 27).

${ }^{264}$ Dentre os catadores de papel há muitas pessoas de baixa renda, que não possuem instrução escolar, moradia, renda pessoal ou familiar adequada, o que não permite condições dignas de vida e nem de acesso ao sistema formal de trabalho. Muitas vezes os catadores de papel são pessoas completamente à margem da sociedade, que se valem dessa atividade para sobreviverem e muitas vezes em condições precárias. A partir da inclusão dessas pessoas na cadeia produtiva propicia um avanço social. A capacitação dos catadores permitirá a eles melhores condições de vida, o que se reflete na redução dos níveis de pobreza do país. Mas isso evidentemente dependerá também de políticas públicas voltadas especificamente a essa capacitação dos catadores.

265 Adota-se a seguinte delimitação para o conceito de procedimento: “(...) o procedimento é essencialmente uma sucessão predeterminada de atos jurídicos, como uma espécie de itinerário a ser seguido.” Observe-se que na literatura estrangeira que trata do tema da logística reversa é comum a utilização do termo processo. No entanto, opta-se pela compreensão do termo como procedimento, visto que, na doutrina brasileira, o "processo, segundo a concepção usual, é uma relação jurídica destinada a compor um litígio mediante a observância necessária de um procedimento. Portanto, o processo e uma solução jurídica para a
} 
A logística reversa é procedimento bastante complexo, pelo qual alguns autores aludem à rede de logística reversa. Note-se que logística reversa não envolve apenas a operacionalização do retorno dos resíduos à cadeia produtiva, mas, principalmente o retorno à cadeia produtiva mediante a atribuição de um valor ao resíduo ${ }^{266}$.

Segundo destacam KISHORE K. POCHAMPALLY, SATISH NUKALA e SURENDRA M. GUPTA, a logística reversa envolve as fases de concepção (quando se definem as estratégias a serem adotadas), de planejamento (momento em que se define o modo de implementação) e de operacionalização da tomada de decisões ${ }^{267}$.

Nem todas as empresas concebem processos organizados, de modo que a logística reversa ainda é bastante negligenciada ${ }^{268}$. Ainda há uma limitada dimensão da quantidade de produtos que retornam e também dos custos envolvidos com a operacionalização da logística reversa. Também não se identificam os custos em decorrência da ausência ou da ineficiência na utilização desse mecanismo ${ }^{269}$. No entanto, tornou-se impossível ignorar os impactos que o retorno dos resíduos sólidos gera nas transações econômicas ${ }^{270}$. A competitividade e a boa operacionalização das empresas exigem um planejamento adequado da logística reversa.

\subsection{A destinação final ambientalmente adequada}

A destinação final, nos termos da Lei 12.305/2010 (art. 3ํㅜㄹ. inc. VII), envolve a reutilização, a reciclagem, a compostagem, a recuperação ou outras destinações admitidas pelos órgãos competentes, devendo ser observadas normas operacionais específicas que sejam aptas a evitar danos ou riscos à saúde pública e à segurança e minimizar outros possíveis impactos ambientais.

composição de conflitos de interesses. Tal solução se caracteriza pela adoção de um procedimento que assegure o contraditório e a ampla defesa". (JUSTEN FILHO, Marcal. Curso de Direito Administrativo. 10. ed., 2014, p. 357).

${ }^{266}$ ROGERS, Dale; TIBBEN-LEMBKE, Ron. Going Backwards: Reverse Logistics Trends and Practices, 1999, p. 2.

${ }^{267}$ Strategic Planning models for reverse and closed-loop supply chains, 2008, p. 11.

${ }^{268}$ CURTIS GREVE e JERRY DAVIS identificam esse panorama em relação à boa parte das empresas norte-americanas. Sobre o tema, confira-se: Executive's guide to reverse logistics: how to find hidden profits by managing returns, 2012, p. 23.

${ }^{269}$ CURTIS GREVE; JERRY DAVIS, Executive's guide to reverse logistics: how to find hidden profits by managing returns, 2012, p. 26).

${ }^{270}$ LEITE, Paulo Roberto. Logística Reversa. Meio ambiente e competitividade. 2 ed., 2009, p. 15. 


\subsection{A operacionalização da logística reversa}

Anteriormente apresentou-se uma delimitação do que seja a logística reversa e nos tópicos adiante irá se detalhar o seu modo de operacionalização.

A etapa inicial é a de coleta, que geralmente é feita nas residências. Mas também é possível existirem pontos de entrega, nos quais o consumidor leva o produto para descarte. A depender do tipo de resíduo ou da localidade em que se coleta, poderá ser imprescindível a construção de estações de transbordo ${ }^{271-272}$ para o armazenamento dos rejeitos que foram coletados.

Posteriormente, há uma etapa de triagem dos resíduos coletados. Nessa etapa se verifica qual será o destino do resíduo, se será reuso ${ }^{273}$, remanufatura ou recuperação. Em seguida, há a redistribuição do resíduo para o local de tratamento ${ }^{274}$. Como etapas intermediárias, há o transporte e a armazenagem.

Se não for possível o reaproveitamento, será necessário o encaminhamento ao aterro sanitário, incinerador, usina de compostagem, usina de aproveitamento energético, a depender do tipo de rejeito.

\footnotetext{
${ }^{271}$ Mas essa infraestrutura poderá não ser necessária. Em Campinas os resíduos sólidos domiciliares são encaminhados diretamente ao aterro sanitário, que se localiza no próprio município. Não há estação de transbordo ou triagem. Para maior aprofundamento do tema, consulte-se: PINHEIRO, Maria Andrade; Bartholomeu, Daniela Bacchi; CAIXETA-FILHO, José Vicente, Logística de Resíduos Sólidos em Campinas, 2011, p. 180.

${ }^{272}$ Nessa linha, confira-se: “Esta etapa consiste na guarda temporária dos recipientes contendo os resíduos já acondicionados, em local próximo aos pontos de geração, visando agilizar a coleta dentro do estabelecimento e otimizar o deslocamento entre os pontos geradores e o ponto destinado à disponibilização para a coleta externa" (BARTHOLOMEU, Daniela Bacchi; BRANCO, José Eduardo Holler; CAIXETAFILHO, José Vicente, Caracterização da Logística Reversa de Resíduos de Serviços de Saúde (RSS), 2011, p. 56).

${ }^{273}$ No caso dos equipamentos eletroeletrônicos é interessante observar que, sobretudo em países em desenvolvimento, o reuso e o recondicionamento são bastante comuns, embora a venda dos produtos originais se dê em larga escala. Tal se passa não apenas na fase dos pós-venda, mas também de pós-consumo. (XAVIER, Lúcia Helena; CARVALHO, Tereza Cristina Melo de Brito, Introdução à Gestão de Resíduos de Equipamentos Eletroeletrônicos, 2014, p. 5).

${ }^{274}$ No caso da valorização do alumínio, há a coleta, posteriormente, o material coletado passa por uma de triagem, por limpeza e pela compactação. Os fardos compactados são encaminhados para a usina de reciclagem. O alumínio, então, é picotado em fragmentos menores, para que possam passar por uma separação eletromagnética, que filtre a terra, areia e qualquer outro resíduo. Os pedaços de alumínio são dispostos em fornos que eliminam tintas, vernizes, para que se possam encaminhá-los para o processo de fusão. Nesse processo forma-se uma liga de alumínio e outros metais para que se atinja a composição química desejada e para que possa reinseri-lo na cadeia produtiva. Para maiores informações, consulte-se: http://www.alumar.com.br/internas template4.aspx?spbid=11\&tbsid=10. Acesso em 19.11.2014.
} 


\subsubsection{Coleta}

A coleta pode ser realizada também por catadores de papel, organizados ou não sob a forma de cooperativas, e empresas informais ${ }^{275}$. Em alguns locais as modalidades se conjugam, ou seja, há tanto a coleta porta-a-porta, como coleta por catadores e pontos de entrega voluntária.

Segundo dados da pesquisa realizada pelo Ipea, que foi divulgada em $2012^{276}$, quase $90 \%$ dos domicílios brasileiros possuem sistema de coleta de resíduos. A regularidade da coleta também se diferencia em cada localidade, podendo ser diária ou alternada.

Mas a grande problemática é que nem toda coleta realizada é seletiva. Com isso pode ocorrer a contaminação de resíduos que poderiam ser reaproveitados. Isso porque, sem uma separação prévia ao descarte, os resíduos se misturam e reduzem a qualidade do material a ser reciclado, ocasionando inclusive a redução dos preços negociados na venda dos recicláveis ${ }^{277}$. Em função disso será necessária a instalação de unidades de triagem do material coletado ${ }^{278}$.

A coleta pode envolver todo tipo de resíduo domiciliar ou ainda ser organizada pelo tipo de material (plástico, vidro, alumínio, embalagens, etc.), marca do produto (como ocorre no setor de telecomunicações), consórcio entre empresas ${ }^{279}$ que recolhem seus próprios produtos, como embalagens, pilhas, pneus, lâmpadas ${ }^{280}$.

Como destaca PAULO ROBERTO LEITE: "O sistema de coleta tem sido apresentado não só como uma das melhores soluções para a redução do lixo urbano, mas também como uma excelente alternativa para a captação dos descartáveis em geral $^{281, "}$.

\footnotetext{
${ }^{275}$ Destaque-se que o recolhimento informal de resíduos, que seja realizado por indivíduos que não são capacitados para tal atividade, pode representar risco tanto para quem coleta esses resíduos, para a sociedade como para o meio ambiente. Pense-se nos casos de coleta de produtos eletroeletrônicos, que contém diversos elementos tóxicos, lâmpadas fluorescentes que contém mercúrio, óleo lubrificante usado, casos em que é necessária a adoção de diversas cautelas para que seja feito o seu reaproveitamento adequado. O manejo indevido poderá inviabilizar a reutilização desse resíduo e ainda contaminar o solo e mananciais.

${ }^{276}$ Diagnóstico dos Resíduos Sólidos de Logística Reversa Obrigatória - Relatório de Pesquisa Ipea, 2012, p. 9.

${ }^{277}$ BARTHOLOMEU, Daniela Bacchi; BRANCO, José Eduardo Holler; CAIXETA-FILHO, José Vicente, A logística de transporte dos resíduos sólidos domiciliares (RSD), 2011, p. 32.

${ }^{278}$ Nessa linha MARIA ANDRADE PINHEIRO, DANIELA BACCHI BARTHOLOMEU e JOSÉ VICENTE CAIXETA-FILHO destacam: "O processo de triagem de RSD pode ser significativamente facilitado quando os resíduos são coletados já separados de alguma forma. Nesse sentido, a 'coleta seletiva' pode ser considerada a primeira etapa do processo de reutilização dos resíduos, e a sociedade, o primeiro grupo de agentes envolvidos no contexto” (Logística de Resíduos Sólidos em Campinas, 2011, p. 176).

279 A utilização dessa figura é muito comum no setor de óleo lubrificante e também de defensivos agrícolas.

${ }^{280}$ XAVIER, Lúcia Helena; CORRÊA, Henrique Luiz. Sistemas de logística reversa. Criando cadeias de suprimento sustentáveis, 2014, p. 199.

${ }^{281}$ Logística Reversa. Meio ambiente e competitividade. 2. ed., 2009, p. 71.
} 
Na Alemanha existe um controle legal das quantidades de resíduos que podem ser dispostas nos aterros sanitários. Em algumas regiões define-se uma quantidade máxima de lixo que poderá ser coletada por residência. Esse valor é calculado a partir de dados estatísticos. A parcela que for excedente deve ser guardada até a próxima data de coleta $^{282}$.

No Brasil a venda de materiais coletados se dá em leilões, com objetivo de estimular o reuso, sobretudo de sucatas e de equipamentos de segunda mão, ou seja, usados. Após a coleta todas as máquinas, bens, utensílios, ou mesmo partes e componentes de equipamentos que ainda possam ser utilizados passam a ser comercializados num mercado secundário ${ }^{283}$.

Já nos Estados Unidos, há previsão (no apêndice 246.201-8 do Code of Federal Regulations) de que devem ser celebrados contratos para a venda dos materiais reciclados. A intenção de celebração deve ser solicitada formalmente. O procedimento é muito similar à figura do leilão prevista na Lei 8.666/1993, haja vista a necessidade de serem formulados lances pelos interessados, em conformidade com os procedimentos de licitação do órgão responsável. Os contratos devem conter especificações das qualificações do comprador, informações sobre quantidades e acordos de transporte do material reciclado. Sendo necessário prever-se um preço mínimo de compra, a qual deve ser adquirida ao longo de, no mínimo, um ano.

\subsubsection{Triagem}

Independentemente do modelo escolhido para a logística reversa, os resíduos devem passar por essa etapa de triagem, também denominada pré-processamento ${ }^{284}$.

Os resíduos, em muitos casos, são misturados no descarte. Então, há resíduos de diversos tipos, matéria orgânica e rejeitos. Na triagem é possível identificar cada tipo de resíduo e verificar o que pode ou não ser reaproveitado.

DANIELA BACCHI BARTHOLOMEU; JOSÉ EDUARDO HOLLER BRANCO e JOSÉ VICENTE CAIXETA-FILHO realizaram um estudo sobre a coleta de resíduos em São José do Rio Preto/SP e identificaram que antes da coleta não há qualquer separação dos resíduos, ou seja, tanto a matéria orgânica como materiais passíveis de reciclagem e “lixo não reaproveitável” [rejeitos] são dispostos de modo conjunto. Ou seja, não há coleta

\footnotetext{
${ }^{282}$ CAIXETA-FILHO, José Vicente; BARTHOLOMEU, Daniela Bacchi, Modelagem da Roteirização da Coleta de Resíduos Sólidos Urbanos, 2011, p. 222.

${ }^{283}$ LEITE, Paulo Roberto. Logística Reversa. Meio ambiente e competitividade. 2. ed., 2009, p. 11.

${ }^{284}$ BARTHOLOMEU, Daniela Bacchi; BRANCO, José Eduardo Holler; CAIXETA-FILHO, José Vicente. A logística de transporte dos resíduos sólidos domiciliares (RSD), 2011, p. 32.
} 
seletiva. Esses autores identificam que "O aspecto negativo desse tipo de programa é que acaba reduzindo a qualidade do resíduo reciclável (...). Em geral, os preços negociados na venda dos recicláveis acabam tendo um deságio em função disso ${ }^{285}$ ”. Isso exige uma estrutura de triagem mais complexa.

Com a coleta seletiva parte da triagem dos itens descartados é realizada pelos geradores. Isso aumenta a qualidade do material reciclado. Nesse sentido a participação da sociedade como um todo é imprescindível para essa etapa funcionar adequadamente ${ }^{286}$.

\subsubsection{Armazenagem}

Quando não for possível deslocar diretamente os resíduos do local de coleta até o ponto de triagem ou de tratamento, será necessária a armazenagem dos resíduos em uma estação de transbordo. É uma guarda temporária, um acondicionamento dos resíduos em locais em local próximo aos pontos de geração. Evidentemente, o ponto de armazenagem pode ser dispensável quando a distância entre o ponto de geração e a unidade de triagem for reduzida ${ }^{287}$.

A escolha do local de instalação dos locais de disposição final precisa levar em conta diversos fatores. O primeiro deles é o planejamento urbanístico. Afinal, há possibilidade de que sejam estabelecidas distâncias mínimas dos centros urbanos ${ }^{288}$, de modo a evitar que a população tenha de suportar os efeitos gerados pelo depósito de resíduos, como o mau cheiro e a desvalorização dos imóveis etc ${ }^{289}$. No entanto, a distância dos centros de geração de resíduos não deve ser muito grande a ponto de tornar economicamente inviável os custos com o transporte.

\subsubsection{A distribuição}

O retorno dos resíduos à cadeia produtiva exige uma fase que permita a sua distribuição. Desse modo, o transporte é uma atividade inerente à logística reversa.

A escolha do modal a ser utilizado é relevante sob o ponto de visto econômico e inclusive ambiental, porque a depender da escolha é possível reduzir-se custos e a poluição

\footnotetext{
${ }^{285}$ Caracterização da Logística Reversa de Resíduos de Serviços de Saúde (RSS), 2011, p. 32.

${ }^{286}$ BARTHOLOMEU, Daniela Bacchi; BRANCO, José Eduardo Holler; CAIXETA-FILHO, José Vicente, Caracterização da Logística Reversa de Resíduos de Serviços de Saúde (RSS), 2011, p. 32.

287 BARTHOLOMEU, Daniela Bacchi; BRANCO, José Eduardo Holler; CAIXETA-FILHO, José Vicente, Caracterização da logística reversa de pneus inservíveis, 2011, p. 56.

288 ARINAS, René Javier Santamaría. El régimen jurídico de los vertederos de residuos. Estudio jurisprudencial, 1998, p. 52-53.

${ }^{289}$ A Lei 4.435/1984 veda a instalação de usinas de beneficiamento de resíduos a um raio de 2,5km da fonte dos Jesuítas, localizada no Município de Embu.
} 
inerente à atividade de transporte. Embora, qualquer que seja o modal escolhido, haverá um impacto ambiental, mas em alguns casos isso poderá ser mais bem administrado. Além disso, o transporte de resíduos também pode ser feito de maneira intermodal. Há possibilidade de conjugação das diferentes modalidades para o transporte dos resíduos.

A gestão eficaz da etapa de distribuição beneficia a gestão de todo o sistema ${ }^{290}$. Qualquer empecilho à sua realização inviabilizará o reaproveitamento dos resíduos e a disposição final ambientalmente adequada dos rejeitos, visto que o descarte pode se dar de modo e em local impróprios ${ }^{291}$.

Alguns estudos sobre o mapeamento das rotas de transporte dos resíduos buscam localizar modos de otimização dessa atividade, seja tanto em relação à minimização dos níveis de emissão de poluentes como para reduzir a ineficiência da gestão. A partir da utilização do mapeamento das rotas é possível um levantamento do número de veículos necessários, do volume que poderá ser manejado por veículo, da quantidade de combustível necessária, da quantidade de trabalhadores e da porcentagem da população atendida pela coleta. Assim, o número de veículos utilizados no transporte de resíduos pode ser reduzido e do tempo das viagens otimizado ${ }^{292}$.

Alguns autores sugerem como forma de otimização que no processo de transporte da logística direta aproveite-se para se retornar bens de pós-venda e/ou de pós-consumo ${ }^{293}$. Isso dependerá muito das propriedades físicas e químicas dos resíduos ou dos rejeitos, da toxidade e também do modal utilizado. Se for utilizado o transporte ferroviário é possível que, eventualmente mediante a substituição dos vagões, aproveite-se o trajeto de volta para o retorno de resíduos.

\subsubsection{Reciclagem}

A reciclagem é a fase que permite a recuperação dos resíduos sólidos mediante o seu reprocessamento. A partir da reciclagem obtém-se a matéria-prima secundária para a fabricação de novos materiais, que podem ter usos semelhantes ou distintos. Esse aproveitamento permite a recuperação e valorização dos resíduos.

\footnotetext{
${ }^{290}$ BARTHOLOMEU, Daniela Bacchi; BRANCO, José Eduardo Holler; CAIXETA-FILHO, José Vicente, Caracterização da Logística Reversa de Resíduos de Serviços de Saúde (RSS), 2011, p. 41.

${ }^{291}$ CAIXETA-FILHO, José Vicente; BARTHOLOMEU, Daniela Bacchi. Modelagem da Roteirização da Coleta de Resíduos Sólidos Urbanos, p. 209-230, 2011, p. 103.

${ }^{292}$ Sobre o tema, confira-se: KIM, Byung-In; KIM, Seongbae; SAHOO, Suraya. Waste collection vehicle routing problem with time Windows, 2006, p. 3624-3642 e BARROS, Regina Mambeli. Tratado sobre resíduos sólidos. Gestão, uso e sustentabilidade, 2013, p. 83-87.

${ }^{293}$ COSTA, Lourenço; MENDONÇA, Fabrício Molica de; SOUZA, Ricardo Gabbay de, O que é Logística reversa, 2014, p. 31.
} 


\subsection{A disposição ambientalmente adequada}

Nos casos em que, diante da tecnologia existente, não é mais possível se valer de nenhuma técnica de reaproveitamento dos resíduos dever-se-á proceder à fase de disposição ambientalmente adequada. Essa fase consiste na eliminação de rejeitos, o que pode se dar tanto de modo parcial como total. O destino dos resíduos poderá ser aterros sanitários, incineração, compostagem ou aproveitamento energético ${ }^{294}$.

O exercício dessa atividade de ser objeto de outorga aos interessados, mediante uma autorização ou uma licença. Afinal o exercício irregular ou não autorizado pode ocasionar sérios danos ambientais ${ }^{295}$. A ANP, por exemplo, é responsável pela outorga de autorização para empresas coletoras de óleo lubrificante. Atualmente existem vinte e nove empresas que são habilitadas para exercer essa atividade ${ }^{296}$.

A eliminação dos resíduos deve ser feita de modo ambientalmente adequado, ou seja, deve observar critérios sanitários e ambientais. É preciso haver controle e fiscalização intensos da Administração em relação ao cumprimento das exigências normativas e regulamentares para se evitar a contaminação ambiental ou prejuízos à saúde humana e animal. Por tal razão é imprescindível a fixação de critérios técnicos exigíveis ${ }^{297}$.

A fiscalização é inerente a uma parcela do poder de polícia administrativa e logo compete ao Estado realizá-la ${ }^{298}$. Nessa linha destaca Juarez Freitas: "Menos do que 'poder', proclama-se a obrigação administrativa de praticar limitações, fiscalizando, prevenindo e, em último caso, reprimindo o exercício dos interesses em dissonância com a promoção efetiva dos intangíveis direitos fundamentais ${ }^{299,}$.

\footnotetext{
${ }^{294}$ A esse respeito, confira-se: "Só na Europa já se processam 130 milhões de toneladas de lixo, gerando energia térmica em mais de 700 instalações e produzindo mais de 8.800 megawatts de energia elétrica, enquanto nos Estados Unidos existem cerca de 87 usinas que processam 28 milhões de toneladas de lixo gerando cerca de 15 TWH por ano”. (SOUZA, Herval Barros de; RIBEIRO, João Paulo Da Silveira. Aspectos regulatórios da geração de energia elétrica a partir de resíduos sólidos urbanos, 2013, p. 403).

${ }^{295}$ As atividades que envolvem algum tipo de risco ambiental e de saúde pública requerem concessão ou autorização para serem exploradas pelos particulares. A necessidade de outorga a ser concedida pelo ente público já demonstra a importância e o impacto dessas atividades, o que exige um cuidado maior na fiscalização e regulamentação. Se a exploração dessas atividades gerar danos que decorreram de uma atuação defeituosa ou ineficiente do ente estatal é devida a responsabilização civil.

296 A relação de empresas autorizadas pode ser consultada no site da ANP. Disponível em: http://www.anp.gov.br/?pg=72668\&m=coletores\&t1=\&t2=coletores\&t3=\&t4=\&ar=0\&ps=1\&cachebust=141 7301296076. Acesso em 20.11.2014.

${ }^{297}$ GARCÍA, José Francisco Alenza. El sistema de la gestión de resíduos sólidos urbanos en el derecho español, 1997, p. 518-520.

${ }^{298}$ Sobre o tema, confira-se: "3. A atividade fiscalizatória das atividades nocivas ao meio ambiente concede ao IBAMA interesse jurídico suficiente para exercer seu poder de polícia administrativa” (AgRg no REsp 1373302/CE, 2. ${ }^{\text {a }}$ T., rel. Min. Humberto Martins, j. 11.06.2013, DJe 19.06.2013)

${ }^{299}$ FREITAS, Juarez. Direito fundamental à boa administração pública e o reexame dos institutos da autorização de serviço público, da convalidação e do 'poder de polícia administrativa', 2012, p. 332.
} 
No caso de ser verificada alguma irregularidade no exercício das atividades autorizadas há possibilidade de o poder público suspender ou cassar a autorização. Para tanto podem ser exigidos relatórios de acompanhamento ou serem realizadas inspeções in loco. Além de serem adotadas medidas que minimizem a possibilidade de ocorrência de danos. Afinal, esse poder de fiscalização não é uma mera faculdade, mas uma garantia que 'vincula e responsabiliza' ${ }^{, 300}$.

\subsection{Os atores envolvidos na logística reversa}

Os atores responsáveis pela logística reversa podem ser: o poder público, os produtores, os fabricantes, os comerciantes, os consumidores. Compete a cada qual assumir os deveres e obrigações proporcionais a sua participação na geração dos resíduos e rejeitos.

É possível que existam agentes intermediários que auxiliem na coleta, na triagem, no transporte, no recondicionamento, na remanufatura, na reciclagem. Também há os agentes que compram os resíduos e materiais reprocessados ou que são passíveis de reutilização.

Existem inúmeras maneiras de sistematizar e organizar a atuação desses atores. É possível que os players organizem-se de (i) modo individual, (ii) por meio de parcerias, como a parceria público-privada, (iii) por meio de fundações ou ainda pelo (iv) exercício direto seja do poder público ou dos produtores e fabricantes, sendo admitidas outras possibilidades.

Em alguns casos, os próprios fabricantes podem optar por fazer a reciclagem, a fim de evitar intermediários que revendem seus produtos a um preço mais baixo.

\subsection{Logística reversa praticada antes da instituição da PNRS}

Antes mesmo da PNRS já eram praticados alguns sistemas de logística reversa. A regulamentação se dava por lei ou, principalmente, por meio de resoluções do CONAMA.

\footnotetext{
${ }^{300}$ FREITAS, Juarez. Direito fundamental à boa administração pública e o reexame dos institutos da autorização de serviço público, da convalidação e do 'poder de polícia administrativa', 2012, p.326.
} 


\subsubsection{Embalagens de agrotóxicos}

A Lei 7.802/1989, com alterações incluídas pela Lei 9.974/2000, dispôs sobre a logística reversa para embalagens de agrotóxicos ${ }^{301}$. Essa lei foi regulamentada pelo Decreto 4.074/2002, assim como Resolução do CONAMA 334/2003, que recentemente foi revogada pela Resolução do CONAMA 465/2014. Estabeleceu-se, dentre outras obrigações, que as empresas produtoras e comercializadoras de agrotóxicos, componentes ou afins, devem adotar mecanismos de controle e estímulo à devolução de embalagens, que estejam vazias, além de programas educativos. A implementação dessas ações deve ser dar “em colaboração com o Poder Público” (art. 19, parágrafo único da Lei 7.802/1989).

Os agrotóxicos devem ser registrados e a reutilização de suas embalagens deve ser autorizada pelos órgãos competentes (art. 51 do Decreto 4.074/2002). O art. 3º §6º al. “a” estabelece a proibição do registro e consequentemente da utilização de embalagens de agrotóxicos que não possuírem métodos para tratamento dos resíduos, de modo a evitar riscos ao meio ambiente.

O art. $6^{\circ}$, §2 ${ }^{\circ}$ da Lei 7.802/1989 indica a possibilidade de intermediação da coleta em postos de recebimento das embalagens vazias. Esses estabelecimentos necessitam ser mantidos ou credenciados "por um ou mais estabelecimentos comerciais ou conjuntamente com os fabricantes, destinado a receber e armazenar provisoriamente embalagens vazias de agrotóxicos e afins devolvidas pelos usuários” (art. $1^{\circ}$, inc. XXX, do Decreto 4.074/2002).

\subsection{2 Óleo lubrificante usado ou contaminado}

A logística reversa de óleo lubrificante usado ou contaminado foi inicialmente regulamentada pela Resolução do CONAMA 009/1993, que indicou como um dos pontos prioritários a reciclagem (rerrefino) ${ }^{302}$. Afinal o óleo possui uma capacidade de regeneração muito grande, que permite sucessivos tratamentos para sua utilização ${ }^{303}$.

\footnotetext{
${ }^{301}$ A Lei 7.802/1989, art. $2^{\circ}$, inc. I, al. “a” define agrotóxicos como: “os produtos e os agentes de processos físicos, químicos ou biológicos, destinados ao uso nos setores de produção, no armazenamento e beneficiamento de produtos agrícolas, nas pastagens, na proteção de florestas, nativas ou implantadas, e de outros ecossistemas e também de ambientes urbanos, hídricos e industriais, cuja finalidade seja alterar a composição da flora ou da fauna, a fim de preservá-las da ação danosa de seres vivos considerados nocivos".

${ }^{302}$ Não se compreende a combustão como uma forma de destinação final adequada.

${ }^{303}$ A regulamentação inicial da matéria está associada a uma preocupação de fundo muito mais econômico, em razão da ausência de suficiência na produção de petróleo do que vinculado às questões ambientais em si. Hoje pode se dizer que essa questão relaciona-se em grande medida aos critérios ambientais.
} 
Posteriormente, essa resolução foi revogada pela Resolução do CONAMA 362/2005. A resolução em vigor prevê que a totalidade do óleo lubrificante usado ou contaminado deve ser recolhida e, posteriormente, encaminhada para a destinação final. Isso porque esse óleo produz efeitos nocivos ao meio ambiente, como a produção de gases tóxicos, contaminação do solo ou água. Por tal razão, os coletores devem possuir autorização dos órgãos ambientais e da Agência Nacional do Petróleo - ANP para exercer essa atividade ${ }^{304}$.

O inc. I do art. 16 da Resolução do CONAMA 362/2005 impõe a coleta mensal do óleo lubrificante usado ou contaminado por parte dos produtores e importadores, o que se calcula com base no volume médio de vendas praticado no trimestre civil anterior. Há previsão no art. $2^{\circ}$ da Resolução do CONAMA 362/2005 de que o certificado de coleta deverá conter o volume recolhido de óleo usado ou contaminado. O certificado de recebimento comprova a entrega desse resíduo ao rerrefinador ${ }^{305}$, que é o responsável pela reciclagem.

Em 2012, a Resolução do CONAMA 450 incluiu a exigência de que sejam prestadas informações sobre a produção de óleo lubrificante, geração, coleta e destinação dos óleos lubrificantes usados ou contaminados. O descumprimento da referida resolução está sujeita à aplicação de sanções previstas na Lei 9.605/1998 e no Decreto 6.514/2008.

\subsubsection{Pilhas e baterias}

A Resolução do CONAMA 401/2008 regulamenta a logística reversa de pilhas e baterias, que anteriormente era objeto da Resolução do CONAMA 257/1999.

A responsabilização pela destinação final adequada de pilhas usadas ou inservíveis é atribuída aos fabricantes e importadores. Além disso, prevê-se que os produtos devem possibilitar que o consumidor possa proceder à destinação final do aparelho separadamente. Ou seja, os produtos devem ser concebidos de forma que possibilitem a remoção da pilha ou da bateria (art. 15 da Resolução do CONAMA 401/2008).

\footnotetext{
${ }^{304}$ A Resolução da ANP 19/2009 estabelece os requisitos para obtenção dessa autorização para exercício da atividade de rerrefino de óleo lubrificante usado ou contaminado.

${ }^{305}$ O rerrefino é a modalidade mais comum de reciclagem, mas a Resolução do CONAMA 362/2005 admite o emprego de outras técnicas, desde que tenha eficácia ambiental comprovada e que seja equivalente ou superior ao rerrefino.
} 
Também se estipula a obrigação de que sejam divulgadas informações claras sobre os riscos à saúde humana e ao meio ambiente, destacando-se a necessidade de retorná-las aos revendedores (art. 14 da Resolução do CONAMA 401/2008).

A logística reversa de pilhas e baterias envolve a reutilização, a reciclagem e o tratamento ou a disposição final. Não sendo permitida a disposição ou a destinação finais inadequadas, ou seja, por meio de queima a céu aberto, encaminhamento aos aterros não licenciados, lançamento em corpos d’água (art. 22 da Resolução do CONAMA 401/2008). Uma das medidas adotadas nesse sentido é previsão de capacitação periódica de catadores.

Essa resolução, na parte que trata da educação ambiental, especifica que devem ser incentivadas parcerias com o poder público ou com a sociedade civil para promoção de campanhas educacionais que conscientizem a população sobre a destinação final adequadas dos produtos.

\subsubsection{Pneus}

A quantidade de pneus descartados anualmente é bastante significativa. De acordo com dados da Associação Nacional da Indústria de Pneumáticos - ANIP estima-se que, em 2013, foram produzidos cerca de 68 milhões de unidades de pneus. O descarte inadequado pode causar problemas ambientais e de saúde pública, como a proliferação do inseto vetor da dengue.

A logística reversa foi instituída nesse setor em 1999, por meio da Resolução do CONAMA 258/1999, que estabeleceu metas progressivas de destinação final, considerando para tanto o volume de pneus produzido ou importado. Desde 2005 impõe-se que o percentual de fabricação ou importação seja menor do que o número de unidades inservíveis $^{306}$. Posteriormente, essa resolução veio a ser revogada pela Resolução do CONAMA 416/2009, que atualmente regulamenta a matéria. Com a nova redação estabeleceu-se uma meta de destinação final proporcional ao número de pneus comercializados, ou seja, a cada pneu novo é necessário destinar adequadamente um pneu inservível.

A reinserção do pneu no ciclo produtivo é bastante diversificada, pois ele pode ser reaproveitado em diferenciados segmentos, desde a produção de móveis, equipamentos

\footnotetext{
${ }^{306}$ Art. $3^{\circ}$ da Resolução do CONAMA 258/1999: "IV - a partir de $1^{\circ}$ de janeiro de 2005: a) para cada quatro pneus novos fabricados no País ou pneus novos importados, inclusive aqueles que acompanham os veículos importados, as empresas fabricantes e as importadoras deverão dar destinação final a cinco pneus inservíveis; b) para cada três pneus reformados importados, de qualquer tipo, as empresas importadoras deverão dar destinação final a quatro pneus inservíveis”.
} 
esportivos, tapetes até solado de sapato, cintos, borrachas etc ${ }^{307}$. É possível que haja a reutilização, a reciclagem ou a valorização energética.

A reforma do pneu, por meio da reutilização da carcaça, seja pela recapagem, recauchutagem ou remoldagem ${ }^{308}$ permite aumentar o tempo de vida útil. Além disso, é possível se valer do "coprocessamento ${ }^{309} \mathrm{em}$ fornos de cimenteiras; retortagem ou coprocessamento de pneus com a rocha de xisto pirobetuminoso; pavimentação com asfalto-borracha; queima de pneus inservíveis em caldeiras; utilização na construção civil; regeneração de borracha; desvulcanização; obras de contenção de encostas $(\text { geotecnia })^{310,}$.

Em relação aos pneus inseríveis, ou seja, aqueles que não possam mais passar por reformas e que não são úteis à rodagem, devem ser entregues em pontos de coleta, os quais devem ser mantidos pelos fabricantes e importadores de pneus. Esse armazenamento é provisório. Há também a central de armazenamento possui uma logística mais adequada e que comporta maiores volumes de pneus.

O art. $9^{\circ}$ da Resolução do CONAMA 416/2009 obriga os comerciantes a armazenarem os pneus usados sem transferir qualquer ônus ao consumidor. Essa é uma característica diferencial, que não é prevista em todas as cadeias de logística reversa.

Segundo dados divulgados pela Reciclanip os fabricantes de pneus já investiram mais de R\$ 551 milhões em coleta e destinação final de pneus inservíveis ${ }^{311}$.

\subsubsection{Legislação estadual}

No âmbito estadual também já existiam regulamentações anteriores à edição da PNRS.

\footnotetext{
307 LAGARINHOS, Carlos Alberto Ferreira. Reciclagem de pneus: análise do impacto da legislação ambiental através da logística reversa, 2011, p. 66.

${ }^{308}$ Art. $2^{\circ}$, inc. IV da Resolução do CONAMA 416/2009: "Pneu reformado: pneu usado que foi submetido a processo de reutilização da carcaça com o fim específico de aumentar sua vida útil, como: a) recapagem: processo pelo qual um pneu usado é reformado pela substituição de sua banda de rodagem; b) recauchutagem: processo pelo qual um pneu usado é reformado pela substituição de sua banda de rodagem e dos ombros; c) remoldagem: processo pelo qual um pneu usado é reformado pela substituição de sua banda de rodagem, ombros e toda a superfície de seus flancos”.

309 Como já mencionado no capítulo 2, o coprocessamento é uma técnica, regulamentada pela Resolução 264/1999 do CONAMA, que permite gerar energia que servirá para substituir a utilização de combustíveis na fabricação do cimento.

${ }^{310}$ LAGARINHOS, Carlos Alberto Ferreira. Reciclagem de pneus: análise do impacto da legislação ambiental através da logística reversa, 2011, p. 66.

${ }^{311}$ Dados estimados até o final de 2013. Informações disponíveis em: http://www.reciclanip.org.br/v3/quemsomos-institucional. Acesso em 11.12.2014. A Reciclanip foi criada no ano de 2007 pelos maiores fabricantes de pneus. No entanto, o programa nacional de coleta e destinação de pneus existe desde 1999, o qual foi criado pela Anip - Associação Nacional da Indústria de Pneumáticos.
} 
A Lei 9.264/2009 tratou da Política de Resíduos Sólidos no Estado do Espírito Santo, prevendo em seu art. $3^{\circ}$, inc. XII, a gestão integrada, compartilhada e participativa dos resíduos sólidos, por meio da parceria entre o Poder Público, sociedade civil e iniciativa privada $^{312}$. A percepção da construção de soluções para os problemas de resíduos prevista nessa legislação foi toda pautada na articulação de ações entre todas as partes envolvidas, denotando um viés consensual bastante acentuado ${ }^{313}$.

A Lei 9.264/2009 do Espírito Santo, no art. 19, inc. IX já dispunha de conceito para logística reversa: “(...) instrumento de desenvolvimento econômico e social, caracterizada por um conjunto de ações, procedimentos e meios, destinados a facilitar a coleta e a restituição dos resíduos sólidos aos seus geradores para que sejam tratados ou reaproveitados em novos produtos, na forma de novos insumos, em seu ciclo ou em outros ciclos produtivos, visando a não geração de rejeitos”.

A Lei 18.031/2009 do Estado de Minas, regulamentada pelo Decreto 45.181/2009, também apresentava um conceito de logística reversa: “(...) o conjunto de ações $e$ procedimentos destinados a facilitar a coleta e a restituição dos resíduos sólidos aos geradores, para que sejam tratados ou reaproveitados em seu próprio ciclo produtivo ou no ciclo produtivo de outros produtos" (art. $4^{\text {o }}$, inc. XIV) ${ }^{314}$.

A Lei do Estado do Ceará 13.103/2001 não previa especificamente o termo “logística reversa”, no entanto, pode-se dizer que a gestão dos resíduos já exigia a sua efetivação $^{315}$. O art. 11 dessa lei menciona: (i) a redução da geração de resíduos, (ii) prevenção da poluição, (iii) acondicionamento correto, (iv) coleta, (v) transporte, (iv) o tratamento ambientalmente adequado e também (vi) a recuperação de áreas degradadas por resíduos sólidos ${ }^{316}$. No entanto, o encargo por implementar essa política foi atribuído ao Município de forma direta ou indireta (art. 19), salvo para o caso dos resíduos sólidos industriais, especialmente os perigosos, os quais seriam de responsabilidade dos geradores.

\footnotetext{
${ }^{312}$ Note-se que a lei desconsidera que a sociedade civil já engloba a iniciativa privada. Mas, de qualquer modo, representa um avanço em termos de participação colaborativa e de consensualidade.

${ }^{313}$ Nesse sentido, confira-se ainda a Lei Estadual 7.862/2002 do Mato Grosso prevê no art. $6^{\circ}$, inc. XVIII a participação da comunidade no processo de gestão integrada dos resíduos sólidos.

${ }^{314}$ Essas legislações também incluem a exigência de avaliação do ciclo de vida do produto.

315 No mesmo sentido, a Lei 11.347/2000 do Estado de Santa Catarina não menciona o termo "logística reversa" expressamente, mas a impõe aos fabricantes e importadores de baterias, pilhas e lâmpadas fluorescentes, lâmpadas de vapor de mercúrio, vapor de sódio ou de luz mista, visto que são obrigados a realizar a coleta, o transporte, o armazenamento, a reutilização, a reciclagem, o tratamento e a disposição final de baterias, pilhas e lâmpadas fluorescentes, lâmpadas de vapor de mercúrio, vapor de sódio ou de luz mista.

${ }^{316}$ No Estado do Mato Grosso a Lei 8.876/2008 dispôs sobre a coleta, reutilização, reciclagem, tratamento e destinação final do lixo tecnológico, que envolve eletroeletrônicos, lâmpadas fluorescentes, pilhas, baterias, que estão obsoletos ou danificados.
} 
Os fabricantes e importadores assumiam a responsabilidade pelos impactos ambientais em relação aos resíduos perigosos e em relação aos possíveis efeitos nocivos, mas isso não excluía o dever de comprovarem previamente que os produtos não oferecem risco ao meio ambiente.

A Lei 18.511/2009 do Estado de Minas Gerais indicava a responsabilidade de fabricantes e importadores em adotarem o destino mais adequado ao resíduo, seja reutilização, reciclagem, tratamento ou disposição final. Os produtos deviam ser entregues pelos usuários àqueles que o comercializavam ou à assistência técnica autorizada. Isso obrigava as empresas produtoras e distribuidoras, que comercializavam equipamentos de informática, a criarem e manterem um programa de recolhimento, reciclagem e destruição destes equipamentos sem causar poluição ambiental. No Paraná foi editada a Lei 15.851/2008 para determinar que as empresas produtoras e distribuidoras, que comercializam equipamentos de informática devam criar e manter um programa de recolhimento, reciclagem desses resíduos.

A Lei 5.131/2007 do Estado do Rio de Janeiro, regulamentada pelo Decreto 41.752/2009, obrigava fabricantes, distribuidores, importadores, revendedores e comerciantes de lâmpadas fluorescentes a disponibilizar recipientes para coleta de lâmpadas fluorescentes que fossem descartadas.

A Lei 11.187/1998 do Estado do Rio Grande do Sul tratou do tema do descarte e destinação final de pilhas, lâmpadas fluorescentes, baterias de telefone celular e produtos que contenham metais pesados. A Lei 10.888/2001 do Estado de São Paulo já dispunha sobre a obrigação de os fabricantes, distribuidores, importadores, comerciantes ou revendedores de produtos potencialmente perigosos recolherem, descontaminarem e procederem à destinação final ou ainda à disposição final.

Havia outras leis estaduais que regulavam o tema do manejo dos resíduos antes da PNRS, como, por exemplo, a Lei Estadual de Pernambuco 12.008/2001, a Lei 14.248/2002 do Estado de Goiás e a Lei 3.232/2003 do Distrito Federal.

\subsection{Setores da logística reversa previstos na PNRS}

O art. 33 da Lei 33 da Lei 12.305/2013 prevê a obrigatoriedade de implementação da logística reversa para os setores de: (i) agrotóxicos, o que envolve tanto resíduos como embalagens e também os produtos cuja embalagem se torne um resíduo perigoso após o uso, (ii) pilhas e baterias, (iii) pneus, (iv) óleos lubrificantes, tanto resíduos como 
embalagens, (v) lâmpadas fluorescentes, de vapor de sódio e mercúrio e de luz mista e (vi) produtos eletroeletrônicos e seus componentes. Adiante serão apresentados casos de logística reversa que foram instituídos após a edição da Lei 12.305/2010.

\subsubsection{Exemplos de plano estadual e municipal de logística reversa: o setor de medicamentos}

A Lei do Estado do Paraná 17.211/2012, regulamentada pelo Decreto 9.213/2013, instituiu a logística reversa no setor de medicamentos paranaense ${ }^{317}$. Essa lei trata dos medicamentos em desuso, que estejam vencidos ou não, mas que sejam resíduos classificados como domiciliares $^{318}$. Essa lei também abarca a regulação das embalagens ditas primárias, que são aqueles recipientes que servem para o acondicionamento dos medicamentos e que entram em contato direto ${ }^{319}$.

As fabricantes, importadoras e distribuidoras são responsáveis pelos aspectos técnicos e financeiros necessários para o desenvolvimento e a implementação dos pontos de coleta dos medicamentos em desuso. A participação dos consumidores deve se dar através da entrega voluntária de medicamentos em desuso nesses pontos de coleta.

Os estabelecimentos comerciais devem comprovar a adequação ao Plano de Gerenciamento de Resíduos Sólidos para que a autoridade competente pela emissão do alvará de funcionamento possa certificar que há a destinação adequada dos medicamentos em desuso. Essa condição poderá ser substituída pela adesão a algum termo de compromisso ou acordo setorial, que sejam devidamente certificados (art. 13 do Decreto 9.213/2013).

A logística reversa de medicamentos em desuso exclui a possibilidade de reutilização, seja para uso humano ou veterinário. Assim como a disposição a céu aberto, em mananciais, corpos d’água, em instalações ou equipamentos não licenciados e/ou não adequados ou ainda que sejam lançados na rede de esgoto.

O art. 11 do Decreto 9.213/2013 prevê a necessidade de licenciamento dos veículos e equipamentos a serem utilizados pelas empresas atuem no transporte, tratamento

\footnotetext{
${ }^{317}$ Antes da edição da PNRS o tema já era regulado pela Lei 13.039/2001, posteriormente, alterada pela Lei $16.322 / 2009$.

${ }^{318}$ Os resíduos sólidos de serviços da saúde são objeto de regulamentação específica, como a Resolução da Diretoria Colegiada da ANVISA 306/2004, que dispõe sobre o gerenciamento e a Resolução do CONAMA $n^{\circ}$ 358/2005 que trata da disposição final.

${ }^{319}$ As embalagens secundárias, ou seja, aquelas que não entram em contrato direto com o medicamento devem ser objeto de regulamentação específica.
} 
e destino final de medicamentos em desuso. A NBR 7500 dispõe sobre os critérios de identificação desses veículos.

O Município de Curitiba editou a Lei 13.978/2012 para regulamentar o sistema de coleta por estabelecimentos que comercializam medicamentos ${ }^{320}$. O art. $1^{\circ}$ obriga os pontos de venda de medicamentos de Curitiba a disponibilizarem recipientes adequados e de fácil identificação para coleta de medicamentos domiciliares, que estejam vencidos ou não tenham sido utilizados. Essa lei ainda especifica que a logística reversa é de competência da indústria, fabricantes, manipuladoras, importadoras e distribuidoras, em regime de corresponsabilidade.

As sanções previstas tanto pelo decreto estadual, que regulamenta a Lei 17.211/2012, como pela legislação municipal acima referida, envolvem a advertência ou a aplicação de multa. Em nenhum dos casos há previsão de qualquer tipo de compensação ambiental. Mas no caso da lei municipal há previsão de repasse dos valores para o Fundo Municipal do Meio Ambiente para que seja revertido em programas, projetos e ações ambientais.

Em dezembro de 2014, foi assinado um plano estadual entre a Secretaria do Meio Ambiente e Recursos Hídricos, a Vigilância Sanitária do Estado do Paraná e representantes da Federação das Indústrias do Paraná - Fiep e do Sindicato das Indústrias Químicas e Farmacêuticas do Estado do Paraná - Sindfar, para operacionalizar a implementação da logística reversa.

A Lei 5.092/2013 dispõe sobre a obrigatoriedade das farmácias e drogarias efetuarem a coleta de medicamentos vencidos no âmbito do Distrito Federal. O art. $1^{\circ}$ dessa lei especifica que não deve haver qualquer obrigatoriedade de concessão de descontos aos consumidores pela entregada do resíduo. Esse é um ponto importante, porque depende muito de cada modelo de logística reversa. Em alguns casos e a depender de cada tipo de material, pode haver incentivos ao consumidor ${ }^{321}$.

A Lei 3.676/2011 do Estado do Amazonas também dispõe sobre a coleta de medicamentos vencidos ou estragados. Essa lei impõe a obrigação de coleta aos

\footnotetext{
${ }^{320}$ O município de Curitiba também regulamentou o tratamento e a disposição final de resíduos especiais, como pneumáticos, pilhas e baterias, lâmpadas, embalagens de tintas, solventes e óleos lubrificantes e equipamentos eletroeletrônicos, por meio da Lei 13.509/2010.

${ }^{321}$ Em diversos países, como Alemanha, Holanda, Austrália há máquinas em que se pode depositar garrafas pet que conferem créditos para a troca de produtos, alimentos e brindes. Na China os créditos obtidos com a troca das garradas pet poderão ser trocados por passagens de metrô. A estratégia é bastante interessante, porque não incentiva o consumo de mais produtos e estimula o uso do transporte público. Informações disponíveis em: http://planetasustentavel.abril.com.br/blog/blog-da-redacao/na-china-populacao-trocagarrafas-pet-por-passe-livre-no-metro/. Acesso em 15.8.2014.
} 
laboratórios fabricantes e aos distribuidores. A lei objetiva estimular o descarte desse resíduo em pontos de coleta e não juntamente com os resíduos domiciliares que são coletados em cada residência. A penalidade pelo descumprimento da lei é a aplicação de multa, não se prevendo a sanção de advertência.

Na Paraíba o tema é disposto pela Lei Estadual 9.646/2011. No entanto, essa lei obriga as drogarias e farmácias apenas a receberem os medicamentos vencidos ou impróprios para o consumo. À Administração Pública compete providenciar recipientes que serão utilizados para o armazenamento desses resíduos e a disposição final, seja por meio de incineração ou do encaminhamento dos resíduos a aterros sanitários.

\subsection{Comitê Orientador para implementação de Sistemas de Logística Reversa - CORI}

O Comitê Orientador para implementação de Sistemas de Logística Reversa, instituído no dia 17 de fevereiro de 2011, é formado pelos Ministérios do Meio Ambiente, da Saúde, da Fazenda, da Agricultura, Pecuária e Abastecimento e do Desenvolvimento, Indústria e Comércio Exterior.

Existem cinco grupos técnicos que prestam assessoria na área de descarte de medicamentos, embalagens em geral, embalagens de óleos lubrificantes, lâmpadas fluorescentes. Esses grupos elaboram as minutas de edital de chamamento para a realização de acordos setoriais e também auxiliam na realização de estudos de viabilidade técnica e econômica.

O Grupo Técnico de Assessoramento GTT01 funciona como instância de instrução das matérias relativas ao descarte de medicamentos, o Grupo Técnico de Assessoramento GTT02 trata das embalagens em geral, o Grupo Técnico de Assessoramento GTT03 aborda as embalagens de óleos lubrificantes e seus resíduos, o Grupo Técnico de Assessoramento GTT04 se relaciona aos produtos eletrônicos e o Grupo Técnico de Assessoramento GTT05, envolve o os resíduos de lâmpadas fluorescentes, de vapor de sódio e mercúrio e de luz mista.

\subsection{O impacto regulatório no meio ambiente econômico}

A modelagem para a implantação da logística reversa deve levar em conta alguns aspectos como (i) a fonte de recursos para viabilização; (ii) a responsabilidade pelos produtos órfãos; (iii) as metas para recolhimento e reciclagem; (iv) o grau de 
responsabilidade do Poder Público, (v) a toxicidade dos resíduos (se são resíduos perigosos ou não perigosos); (vi) a possibilidade de reuso; (vi) a separação ou não dos resíduos por marcas e o modelo de competição (se será de monopólio ou competitivo) e (vii) a eventual segregação da gestão da infraestrutura e da gestão da operacionalização das atividades de logística reversa dos resíduos. Isso irá se diferenciar muito a depender de cada tipo de resíduo.

O estudo de viabilidade tem de apresentar cálculos para estimativas do custo de triagem dos resíduos, custo com transporte, custo de processamento, custos com pontos de coleta e/ou com pontos de armazenagem, custos de reciclagem, custos com a tributação. O tempo de vida útil e volume dos resíduos também devem ser considerados.

Além disso, a implementação da logística reversa requer uma infraestrutura que seja capaz de permitir o recebimento, o armazenamento, o reprocessamento, o deslocamento (de resíduos para a indústria e rejeitos para aterros) ou outra forma de destinação final que se reputar adequada, como a compostagem, por exemplo.

A disponibilização de espaços para armazenamento dos resíduos, a depender da região em que forem localizados, pode demandar grandes aportes de recursos. Isso gera uma preocupação com a forma de compartilhamento dos custos entre os players. A concepção legal de responsabilidade compartilhada, ou seja, o dever de executar ações de logística reversa terá de ser isonômica, de maneira que todos os envolvidos possam colaborar na medida do impacto provocado pela atividade desenvolvida.

Alguns problemas identificados no atual contexto são a informalidade na comercialização e importação de produtos, que não possuem agentes responsabilizáveis no país. Outro problema também envolve a concepção dos produtos, ou seja, a racionalidade produtiva da obsolência programada dos produtos, que são feitos para durar cada vez menos, em função de novas descobertas tecnológicas.

\subsection{Custos da logística reversa}

A logística reversa envolve diversos custos, que se associam a cada uma das diferentes etapas. Há os custos que se relacionam à gestão das atividades inerentes à logística reversa e outros que se relacionam às infraestruturas que são necessárias para o desenvolvimento dessas atividades.

Como em qualquer atividade econômica, há custos diretos e indiretos. Os primeiros subdividem-se em custos fixos e custos variáveis. 
Os custos fixos são aqueles que são produzidos independemente da atividade ser efetuada, como, por exemplo, valores pagos aos prestadores de serviços, seguros, tributos. Esses custos envolvem o atingimento das metas previstas na gestão da logística reversa.

Os custos variáveis que são os que se modificam a depender da prestação do serviço seja o custo com combustível, custos de manutenção e reparações nos equipamentos e nos veículos de transportes. Há custos com o transporte e armazenagem dos resíduos.

Os custos indiretos são aqueles que não envolvem a execução direta da logística reversa, mas que são necessários para o funcionamento adequado do sistema como, por exemplo, os custos de infraestrutura (gastos financeiros para construção); custos de administração (gastos com informatização e sistema de roteirização - no caso do sistema de coleta, de organização dos dados e informações) e custos comerciais (com marketing e publicidade). Há custos com o desenvolvimento do design dos produtos, que devem ser de fácil desmontagem, que requeiram menor quantidade de matéria-prima, que provoquem menos impactos ambientais etc.

Um dos custos indiretos é relacionado à imagem corporativa da empresa ou da marca. Esse é um dos custos que mais preocupam os empresários, porque um efeito negativo sobre a imagem da empresa, muitas vezes, pode ter uma difícil reversão e comprometer até mesmo e principalmente a rentabilidade da empresa. Além disso, estimase que seja muito mais custoso ter de recuperar a credibilidade junto aos consumidores do que mantê-la ${ }^{322}$. Esse custo aumenta conforme maior o grau de conscientização do consumidor acerca de critérios sustentáveis e ambientais ${ }^{323}$.

A logística reversa, assim como as demais atividades econômicas, terá seus custos de gerenciamento reduzidos conforme a escala econômica se acentue. O fluxo de resíduos precisa ter uma quantidade e periodicidade mínimas que possibilitem a viabilidade econômica da logística reversa. No entanto, a logística reversa também deve ser um mecanismo que incentivem a prevenção de resíduos. Então, há sempre que se buscar um equilíbrio entre os níveis adequados de produção e prevenção, sob pena de se comprometer as atividades que viabilizem o fechamento do ciclo produtivo. O fluxo de resíduos que pode ser mantido tem de se ser avaliado caso a caso. Se não houver um equilíbrio nesse sistema, em longo prazo, pode se imaginar que haverá a dificuldade de se manter as quantidades mínimas necessárias para se viabilizar a logística reversa.

${ }^{322}$ LEITE, Paulo Roberto. Logística reversa. Meio Ambiente e competitividade. 2. ed., 2009, p. 28.

${ }^{323}$ LEITE, Paulo Roberto. Logística reversa. Meio Ambiente e competitividade. 2. ed., 2009, p. 27-28. 
Desse modo, a logística reversa se mostra um instrumento que visa à compatibilização entre os diversos interesses - econômicos, sociais e ambientais - e não um modo de buscar a prevalência de um em face dos outros. A estruturação adequada da logística reversa pressupõe um equilíbrio de interesses.

\subsection{Estudos de viabilidade técnica e econômica}

A adoção da logística reversa, sem dúvidas, produz um impacto econômicofinanceiro nos setores aos quais é implantada. Logo, não há como se pensar na implantação da logística reversa sem uma análise profunda de sua viabilidade econômica e técnica. Sem um estudo adequado de seus impactos ou do montante de recursos necessários para cobrir os custos de produzi-la, poderá se tornar inviável implementá-la, deixando-se de proteger o meio ambiente.

O §2 do art. 33 da Lei n. 12.305/2010 prevê: “A definição dos produtos $e$ embalagens a que se refere o $\S 1^{\circ}$ considerará a viabilidade técnica e econômica da logística reversa, bem como o grau e a extensão do impacto à saúde pública e ao meio ambiente dos resíduos gerados”. No Decreto 7.404/2010, que regulamentou a lei que institui a PNRS, também há várias disposições que tratam da viabilidade técnica e econômica. Veja-se o inc. IV do art. 34 que atribui competência ao Comitê Orientador “aprovar os estudos de viabilidade técnica e econômica”.

\subsection{Os instrumentos de efetivação da logística reversa}

A PNRS prevê três instrumentos para efetivação da logística reversa, os acordos setoriais, regulamentos e termos de compromisso (art. 15 do Decreto 7.404/2010).

\subsubsection{Acordos setoriais e a relação com a consensualidade}

O acordo setorial é definido pela Lei 12.305/2010 como um “ato de natureza contratual firmado entre o poder público e fabricantes, importadores, distribuidores ou comerciantes, tendo em vista a implantação da responsabilidade compartilhada pelo ciclo de vida do produto" (art. $3^{\circ}$, inc. I). Ou seja, as obrigações e deveres previstos para a efetivação as PNRS devem ser formalizados, em um documento escrito, que possui natureza contratual, ou seja, pressupõe um vinculo sinalagmático, em que há convergência 
de vontades, mediante o estabelecimento de obrigações e direitos correlatos, para formação de um vínculo jurídico ${ }^{324}$.

Os acordos setoriais permitem a utilização de um método consensual na formulação dos aspectos operacionais da logística reversa, visto que possibilitam maior diálogo e interação entre as partes envolvidas. Isso é um facilitador da implementação da logística reversa, considerando-se a complexidade de ações e agentes envolvidos. O processo de reinserção de resíduos na cadeia produtiva, em muitos casos, é bastante complexo, envolve tecnologias de ponta e investimentos vultosos. É muito difícil definir critérios que impactam a concepção dos produtos, o design, a durabilidade e até mesmo a mudança de hábitos de consumo sem a participação de todos os agentes envolvidos.

A composição de interesses é relevante para o atingimento adequado dos objetivos almejados. A inexistência de acordo prévio para a implantação da logística reversa pode impossibilitar a sua efetivação pela via consensual. A participação do setor produtivo, dos empresários é relevante para o melhor conhecimento das atividades e definição de metas que sejam passíveis de cumprimento. Além disso, o acordo setorial também permite um planejamento mais adequado da gestão de resíduos sólidos ${ }^{325}$.

As políticas públicas relacionadas ao manejo de resíduos e rejeitos necessitam da participação intensa tanto do Poder Público como de empresários e dos próprios cidadãos, de maneira a se chegar a melhor solução possível em cada caso concreto. Cada qual possuirá papel relevante na condução dessas políticas. A atuação coordenada e integrada em todas as atividades, sempre que possível, é imprescindível para a obtenção de bons resultados.

Como já visto acima, muitos dos elementos implementados pela PNRS já estavam previstos de modo esparso nas legislações estaduais sobre o tema. Ou seja, a logística reversa já era prevista em diversos setores, principalmente entre aqueles que hoje possuem previsão de implantação obrigatória pela Lei 12.305/2010. Contudo, até então, a efetividade da logística reversa era, na maioria dos segmentos, insuficiente.

\footnotetext{
${ }^{324}$ OLIVEIRA, Regis Fernandes. Ato Administrativo. 5. ed., São Paulo: RT, 2007, p. 63.

${ }^{325}$ Sobre o tema confira-se o trecho do relatório de pesquisa do Ipea: “(...) sem o acordo prévio e o conhecimento da realidade local, regional ou nacional, o planejamento de metas e ações poderá ser inadequado e, assim, os benefícios da gestão de resíduos sólidos não serão eficientes e/ou eficazes, e os prejuízos ambientais e socioeconômicos continuarão a representar um ônus à sociedade e ao ambiente". (Diagnóstico dos Resíduos Sólidos de Logística Reversa Obrigatória - Relatório de Pesquisa Ipea, 2012, p. 9).
} 


\subsubsection{Acordo setorial de embalagens plásticas para armazenamento de óleo lubrificante}

O primeiro acordo setorial firmado foi no setor de embalagens plásticas para armazenamento de óleo lubrificante, de modo a estruturar um sistema que permita o retorno dessas embalagens aos fabricantes, importadores, distribuidores e comerciantes. Não se aplica para embalagens de óleo lubrificante usado ou contaminado ou às embalagens e recipientes metálicos ou embalagens em geral. Esse acordo foi celebrado, por prazo indeterminado, entre o Ministério do Meio Ambiente e o Sindicato Nacional das Empresas Distribuidoras de Combustíveis e de Lubrificantes - SINDICOM, o Sindicato Interestadual das Indústrias Misturadoras e Envasilhadoras de Produtos Derivados do Petróleo- SIMEPETRO, o Sindicato Interestadual do Comércio de Lubrificantes SINDILUB, a Confederação Nacional do Comércio de Combustíveis e Lubrificantes FECOMBUSTÍVEIS e a Confederação Nacional do Comércio de Bens, Serviços e Turismo - CNC. Anualmente, deverá ser realizado um procedimento de reavaliação dos termos propostos. Em caso de necessidade de alteração, deverá ser formalizado um termo aditivo.

A estrutura do modelo escolhido envolve centrais de recolhimento das embalagens, que as receberá mediante a devolução do consumidor. Caberá aos comerciantes armazenarem temporariamente as embalagens devolvidas pelos consumidores e até que sejam encaminhadas às centrais de recebimento. Nessas centrais o material coletado deve ser pesado e armazenado até que seja encaminhado para destinação final. O repasse das embalagens deve ser feito apenas para recicladoras que sejam licenciadas, que serão responsáveis pelo processamento dos resíduos, que, a partir de então, poderão ser reinseridos na cadeia produtiva.

Esse acordo setorial prevê a importância da cooperação de todas as partes para viabilização do sistema de logística reversa (Cláusula Quarta - das Obrigações). Essa cooperação se dará mediante esforços conjuntos para obtenção dos resultados ajustados; cumprimento dos termos previstos, como metas previstas, prazos e todas as condições e obrigações. A realização de campanhas educativas também deve ser incentivada, para que o consumidor se conscientize da importância de colaborar com a efetivação da logística reversa.

A União tem um papel fundamental na monitorização do acordo setorial, para que se verifique o atingimento das metas propostas e para avaliação de medidas e ajustes que 
sejam necessários. Já os consumidores têm obrigação de retornar as embalagens usadas de óleo lubrificante, o que deve ser feito preferencialmente no ponto de compra.

Os comerciantes devem segregar as embalagens de eventuais restos de óleo que estejam nas embalagens e acondicioná-las em sacos plásticos transparentes.

As quantidades de embalagens que venham a ser encaminhadas para destinação final devem ser registradas no Sistema Nacional de Informações dos Resíduos Sólidos (SINIR).

Há uma meta de atingir a totalidade de unidades federativas municipais até 2016. Até 2014 estima-se ter atingido uma meta de 70\% dessas unidades federativas. Assim como, espera-se atingir a meta de encaminhar para a reciclagem 4.400 toneladas de embalagens plásticas até 2016 (Cláusula Sexta - Das Metas, parágrafo terceiro).

Não se altera com esse acordo setorial os sistemas de logística que já estão licenciados.

\subsubsection{Acordo setorial para a logística reversa de lâmpadas fluorescentes}

O Comitê Orientador para a Implantação da Logística Reversa - CORI, em julho de 2014, aprovou uma proposta de acordo setorial de abrangência nacional para a logística reversa de lâmpadas fluorescentes que tenham vapor de sódio, de mercúrio ou metálico e luz mista, podendo ser compactas ou tubulares, com baixa ou alta pressão, tal como previsto pela PNRS. Não se enquadram nesse acordo as lâmpadas incandescentes e halógenas, assim como as embalagens vazias das lâmpadas.

Esse acordo foi submetido à consulta pública e, em novembro de 2014, foi assinado pelo Ministério do Meio Ambiente e por mais de trinta entidades representativas do setor. Também há três entidades representativas que se qualificam como intervenientes anuentes, como a Associação Brasileira de Importadores de Produtos de Iluminação (ABILUMI); a Associação Brasileira da Indústria de Iluminação (ABILUX) e a Confederação Nacional do Comércio (CNC).

O financiamento da logística reversa prevista nesse acordo setorial será um encargo assumido pelos fabricantes e importadores, mas que será repassado aos consumidores (Cláusula Sétima, parágrafo segundo da versão submetida à audiência pública). Estima-se um custo a ser repassado ao consumidor, que está em torno de quarenta 
centavos por lâmpada ${ }^{326}$. Ainda poderão ser incorporados ao acordo setorial distribuidores e comerciantes que atuarem nos pontos de entrega, mas isso deverá se dar mediante um instrumento próprio. As implantações de pontos de entrega ou de consolidação que não estejam previstas no acordo setorial e forem de interesse de distribuidores e comerciantes deverão ser por eles custeadas.

Deverá ser criada uma ou mais entidades gestoras, às quais serão repassados os recursos necessários para a execução da logística reversa. O cálculo da contribuição é individualizado e levará em conta a proporção de lâmpadas que tenha sido colocada no mercado. Ou seja, não há um valor fixo a ser pago igualmente por todos os fabricantes e importadores. Também não há solidariedade entre as empresas signatárias do acordo.

As lâmpadas descartadas por geradores domiciliares devem ser entregues em pontos de recolhimento das lâmpadas, já aquelas provenientes de geradores não domiciliares devem passar por uma triagem e posterior armazenamento em pontos de consolidação.

E compete à entidade gestora a coordenação de todas as atividades da logística reversa de lâmpadas fluorescentes.

A logística reversa de lâmpadas fluorescentes tem como pilar fundamental a reciclagem. Estima-se que seja possível reciclar em torno de 98\% da matéria-prima utilizada para a fabricação de lâmpadas fluorescentes. Com isso permite-se a reinserção de matérias no ciclo produtivo ${ }^{327}$.

No entanto, a logística reversa poderá envolver ainda questões relacionadas ao processo produtivo em si, como o tipo de lâmpada a ser produzido, a durabilidade, o nível de consumo de energia, dentre outros fatores. Estima-se que sejam vendidas por ano cerca de 300 milhões de lâmpadas incandescentes, cuja durabilidade é de apenas mil horas, e 200 milhões de lâmpadas fluorescentes, que possuem durabilidade um pouco maior de cerca de dez mil horas. A economia de energia com a substituição das lâmpadas incandescentes é bastante significativa ${ }^{328}$. A logística reversa pode ser um instrumento fomentador do aumento do consumo de lâmpadas que com maior durabilidade e que reduzam o consumo de energia.

\footnotetext{
${ }^{326}$ Lâmpadas fluorescentes: onde descartá-las?, 2012, p. 1. Disponível em: http://www.idec.org.br/emacao/revista/livros-inacessiveis/materia/lampadas-fluorescentes-onde-descarta-las/pagina/184. Acesso em 29.12.2014.

${ }^{327}$ Lâmpadas fluorescentes: onde descartá-las?, 2012, p. 1.

${ }^{328}$ Lâmpadas fluorescentes: onde descartá-las?, p. 1.
} 
Esse acordo setorial de lâmpadas fluorescentes terá um prazo de vigência de cinco anos, mas há previsão de que após dois anos de sua implementação deverá ser feita uma reavaliação do acordo para eventuais ajustes e aprimoramentos. O aditamento do acordo deve se dar em instrumento escrito.

Compete à União o monitoramento da implementação do acordo setorial, assim como a participação na divulgação desse acordo a toda a sociedade.

\subsubsection{Acordos negociados}

No direito europeu existem os acordos negociados que são compromissos firmados entre uma empresa ou um grupo de empresas com objetivo de proteger ou realizar alguma medida de recuperação do meio ambiente. Esses acordos são resultado de negociações feitas com as autoridades competentes e os quais são expressamente reconhecidos por essas autoridades ${ }^{329}$.

Os acordos negociados são instrumentos de política ambiental. Há um interesse crescente na utilização de tais acordos porque se permite uma atuação mais proativa por parte do setor empresarial nas eventuais correções e adaptações das atividades produtivas. Além disso, a flexibilidade desse acordo possibilita o atingimento mais rápido e eficiente dos objetivos previstos pela legislação, porque há uma aderência mais rápida e consistente por parte das empresas. Esses acordos também permitem suprir as eventuais assimetrias existentes entre o conhecimento da iniciativa privada e o poder público ${ }^{330}$.

Os acordos negociados podem envolver diversas matérias como: “(...) objetivos de emissão global $\left(\mathrm{SO}_{2}, \mathrm{VOC}, \ldots\right)$, objetivos de qualidade ambiental, objetivos de redução, recuperação e reciclagem de resíduos, redução e eliminação de certas substâncias ou materiais... etc. ${ }^{331}$ ".

Uma discussão que se coloca em relação a esses acordos é a determinação dos critérios que permitam obter-se um equilíbrio entre formalismo e flexibilidade. Quais os limites para reconhecimento dos acordos? ${ }^{332}$

Primeiramente deve se definir claramente os objetivos e responsabilidades que serão imputados as cada uma das partes. Afinal deste modo será possível controlar excessos eventualmente praticados. A transparência desses acordos é fundamental para que seja possível se aferir os resultados pretendidos. Também devem ser previstas revisões,

\footnotetext{
${ }^{329}$ ORTEGA, Francisco Román. Diccionario de Medio Ambiente y materias afines, 1999, p. 243.

330 ORTEGA, Francisco Román. Diccionario de Medio Ambiente y materias afines, 1999, p. 243-244.

${ }^{331}$ ORTEGA, Francisco Román. Diccionario de Medio Ambiente y materias afines, 1999, p. 245.

332 ORTEGA, Francisco Román. Diccionario de Medio Ambiente y materias afines, 1999, p. 247.
} 
para que eventuais progressos técnicos sejam incorporados aos acordos, assim como eventuais modos de resolução de conflito, como no caso de não cumprimento dos termos do acordo $^{333}$. Essa discussão pode ser transposta para os nossos acordos setoriais.

\subsubsection{Os acordos ambientais (environmental agreements)}

Os acordos ambientais são instrumentos contratuais que recorrem aos esforços coordenados da indústria e do governo para a efetivação de políticas ambientais ${ }^{334}$. Esses acordos são voluntários e têm sido firmados para a efetivação de políticas públicas em matéria ambiental como, por exemplo, de controle de emissão de gases poluentes, controle da poluição e gestão de resíduos sólidos ${ }^{335}$.

\subsubsection{Um estudo de caso sobre acordos ambientais}

As experiências práticas com esses acordos têm sido bem sucedidas em países como Bélgica, Dinamarca, França, Alemanha, Itália, Reino Unido, Polônia, Estados Unidos e Holanda ${ }^{336}$. Um estudo elaborado por BETTY GEBERS, RALF JÜLICH, KILIAN BIZER, VERENA INGRAM; JAN WILLEM BIEKART; DELPHINE MISSONNE; RUTH KHALASTCHI aponta que, nesses países, os acordos ambientais, em razão do envolvimento conjugado de diversas partes, conferem maior efetividade à implementação de medidas protetivas ao meio ambiente. Além do que os acordos ambientais podem apresentar propostas de soluções que contemplem uma visão mais diversificada dos problemas que se pretende regular, comportando assim uma maior compatibilização de interesses conflitantes ${ }^{337}$.

Esses acordos ambientais são empregados em alternatividade aos métodos de comando e controle, com vistas a possibilitar um maior nível de efetividade das práticas e públicas de proteção ambiental. Esses métodos não substituem aqueles ditos impositivos,

\footnotetext{
${ }^{333}$ ORTEGA, Francisco Román. Diccionario de Medio Ambiente y materias afines, 1999, p. 247.

${ }^{334}$ No presente tópico não se aprofunda a discussão em relação aos acordos multilaterais por reputar-se que os acordos ora indicados assemelham-se, de modo mais direto, ao tema do presente trabalho. No entanto, há possibilidade de que esses acordos sejam firmados entre signatários de diversos países. Confiram-se alguns acordos ambientais multipartes que foram firmados por países da União Europeia: http://ec.europa.eu/environment/international_issues/pdf/agreements_en.pdf. Acesso em 15.12.2010.

${ }^{335}$ Alguns acordos ambientais da IEA - International Energy Agency podem ser conferidos no seguinte link: http://iea.uoregon.edu/page.php?file=home.htm\&query=static. Acesso em 15.12.2014.

${ }^{336}$ Para maiores informações sobre a cooperação internacional em matéria de acordos ambientais, confira-se: ANDRESEN, Steinar; BOASSON, Elin Lerum; HONNELAND, Geir. International environmental agreements: an introduction, 2011.

${ }^{337}$ Sobre o tema, confira-se: GEBERS, Betty; JÜLICH, Ralf; BIZER, Kilian; INGRAM, Verena; BIEKART, Jan Willem; MISSONNE, Delphine; KHALASTCHI, Ruth. Environmental Agreements. The role and effect of Environmental Agreements in Environmental Policies, 1998.
} 
mas são uma alternativa consensual para a implementação de políticas públicas em matéria ambiental. Esses acordos ainda podem ser combinados com instrumentos econômicos.

Os acordos ambientais ainda podem ser mais dinâmicos em comparação ao processo legislativo e regulatório ${ }^{338}$. Além do que eles podem possibilitar o atingimento da proteção ambiental com menos gastos de recursos públicos, porque as empresas escolhem os métodos para aumentar o custo-benefício da adoção de medidas de proteção ambiental. Embora os autores advirtam que ainda não é possível se afirmar que esses acordos são mais rentáveis do que os demais instrumentos.

Os autores destacam que os instrumentos regulatórios formulados de modo impositivo tendem a ser menos efetivos, porque há menor compreensão por parte dos atores envolvidos da importância de atenderem aos objetivos propostos.

A participação social foi elencada como um elemento essencial para o sucesso, em longo prazo, dos acordos ambientais, sobretudo em relação às soluções que transcendem os interesses das partes envolvidas. Isso porque possibilitam agregar um “espírito de compartilhamento de responsabilidades” entre os atores sociais ${ }^{339}$.

Destacou-se ainda que as negociações devem envolver um número elevado de agentes do setor para que possam ser obtidas mais sugestões quanto à oportunidade e eficácia dos instrumentos ambientais que se pretende adotar, ampliando-se a efetividade das políticas a serem adotadas.

A participação do poder público foi destacada como importante sob vários aspectos, especialmente no tocante à legitimação de acordos ambientais, por meio da adoção de instrumentos de participação democrática.

No entanto, os autores indicaram que os estudos de casos revelam que os acordos ambientais não possuem muita flexibilidade no tocante ao modo de efetivação dos objetivos propostos. Indicou-se que a definição das ações que devem ser executadas pelas partes do acordo é muito precisa, devendo haver maior flexibilidade quanto ao modo de implementação das medidas propostas.

\footnotetext{
${ }^{338}$ Sobre o tema, confira-se o seguinte estudo: GEBERS, Betty; JÜLICH, Ralf; BIZER, Kilian; INGRAM, Verena; BIEKART, Jan Willem; MISSONNE, Delphine; KHALASTCHI, Ruth. Environmental Agreements. The role and effect of Environmental Agreements in Environmental Policies, 1998, p. 3435.

${ }^{339}$ Sobre o tema, confira-se o seguinte estudo: GEBERS, Betty; JÜLICH, Ralf; BIZER, Kilian; INGRAM, Verena; BIEKART, Jan Willem; MISSONNE, Delphine; KHALASTCHI, Ruth. Environmental Agreements. The role and effect of Environmental Agreements in Environmental Policies, 1998, p. 182.
} 
Ainda discutiu-se que a elaboração frequente de acordos ambientais pode conduzir a um desequilíbrio entre os poderes executivo e legislativo. Isso porque os acordos ambientais não dependem da confirmação ou participação do Poder Legislativo.

De qualquer modo, os acordos ambientais foram identificados como um instrumento consensual bastante efetivo para a implementação de políticas de proteção ambiental $^{340}$.

Todos esses mecanismos aplicáveis aos acordos ambientais são semelhantes àqueles da logística reversa, assim verifica-se um exemplo prático de que a consensualidade é importante para efetivação das ações de gerenciamento de resíduos sólidos.

\subsubsection{Regulamentos}

Não existe obrigatoriedade de ser firmado um acordo setorial prévio, visto que a lei faculta a possibilidade de o Poder Público editar diretamente um regulamento. Não consta expressamente na lei uma ordem de gradação entre os instrumentos de implementação da logística reversa. No entanto, reputa-se que o método inicial a ser adotado deva ser a celebração de acordos setoriais. Isso porque são instrumentos contratuais e que permitem uma interação muito maior das partes interessadas com o Poder Público, o que possibilita a valorização de métodos consensuais, os quais são dotados de maior eficácia.

Embora não exista obrigatoriedade em se adotar uma solução consensual, reputase que o caso concreto reúne elementos que a indiquem como recomendável. Primeiro, porque a logística reversa é um instrumento bastante complexo e de difícil implementação, o que exige o reconhecimento por parte dos destinatários quanto a sua importância e legitimidade. Segundo, exige-se, em muitos casos, vultosos investimentos e até mesmo o desenvolvimento de novas estratégias para reformulação do processo produtivo. Além disso, a efetivação prática da logística reversa ainda envolve a atuação de diversos agentes, abrindo-se espaço para a composição de diferentes interesses à efetivação da PNRS.

Os regulamentos podem ser adotados para os casos em que não se chegar a um resultado consensual, ante o insucesso das negociações. Ou seja, em última análise e ante a

${ }^{340}$ Sobre o tema, confira-se o seguinte estudo: GEBERS, Betty; JÜLICH, Ralf; BIZER, Kilian; INGRAM, Verena; BIEKART, Jan Willem; MISSONNE, Delphine; KHALASTCHI, Ruth. Environmental Agreements. The role and effect of Environmental Agreements in Environmental Policies, 1998, p. 183. 
uma situação de conflito, compete ao poder público definir as linhas gerais da logística reversa. Mas com isso não se permite que a Administração Pública imponha métodos inaplicáveis ou metas incompatíveis com a realidade ou com a tecnologia disponível. Não é possível que sejam adotadas medidas sem análise criteriosa da viabilidade técnica e econômica. Por tal razão, a lei impõe a necessidade de realização de Consulta Pública, a ser definida pelo CORI (art. 31 do Decreto 7.404/2010).

Mas o regulamento também pode ser útil para estender a aplicabilidade do modelo de logística reversa a todos os agentes do setor, visto que o acordo setorial exige a adesão de cada empresa signatária e o regulamento, por sua vez, pode ser aplicável indistintamente a todas as empresas, sejam fabricantes, importadores, comerciantes ou distribuidores.

O regulamento não poderá inovar o que for previsto em $l \mathrm{i}^{341}$. A atividade de elaboração do regulamento exige observância de todas as regras jurídicas que podem ser aplicáveis, para que as obrigações e direitos nele previstos estejam em consonância com a lei que regulamente, não sendo possível exorbitar dos limites legais ${ }^{342}$.

\subsubsection{Termos de compromisso}

Há ainda possibilidade de serem firmados termos de compromisso entre o Poder Público e fabricantes, importadores, distribuidores ou comerciantes, nos casos em que não houver sido firmado acordo setorial e nem regulamento específico.

Com isso pretende-se garantir que os interessados em implementar a logística reversa possam delimitá-la, resguardando direitos e definindo obrigações, até que acordos setoriais ou regulamentos sejam firmados. Então, se não houver um consenso quanto ao fechamento do acordo setorial ou a edição de regulamento, é possível firmar-se um termo de compromisso. Esse termo deverá ser homologado pelo órgão ambiental competente.

\footnotetext{
341 Nesse sentido já se manifestou o STJ: “1. O decreto, como norma secundária - que tem função eminentemente regulamentar, conforme o art. 84, inc. IV, da Constituição Federal -, não pode contrariar ou extrapolar a lei, norma primária. Não pode restringir os direitos nela preconizados. Isso porque tão-somente a lei, em caráter inicial, tem o poder de inovar no ordenamento jurídico”. (STJ, RMS 22.828/SC, 5a T., rel. Min. Arnaldo Esteves Lima, j. 18.03.2008, DJe 19.05.2008)

342 Como destaca PONTES DE MIRANDA: "Se o regulamento cria direitos ou obrigações novas, estranhas à lei, ou faz reviverem direitos, deveres, pretensões, obrigações, ações ou exceções, que a lei apagou, é inconstitucional. Por exemplo: se faz exemplificativo o que é taxativo, ou vice-versa. Tampouco pode êle limitar, modificar ou ampliar direitos, deveres, pretensões, obrigações, ações ou exceções. Não pode facultar o que na lei se proíbe, nem lhe procurar exceções à proibição, salvo se estão implícitas. Nem ordenar o que a lei não ordena.”. (PONTES DE MIRANDA, Francisco Cavalcanti. Comentários à Constituição de 1967 com a emenda no 1, de 1969, T. 3, 2. ed., 1973, p. 316).
} 
Se já houver regulamento ou acordo setorial, ainda assim poderá ser possível a aplicação dessa figura para a fixação de metas e compromissos mais rigorosos. De qualquer modo, o termo de compromisso não se assemelha ao termo de ajustamento de conduta ou a um termo de ajuste de gestão ${ }^{343}$, porque o seu objeto não se volta a possibilitar a substituição de uma sanção, mas sim regular os direitos e deveres jurídicos atinentes à implementação da logística reversa. Com isso não se veda a previsão de sanções, mas esse não deve ser o escopo principal de sua celebração.

\footnotetext{
${ }^{343}$ Nesse sentido, confira-se: "A doutrina brasileira tem sustentado a possibilidade de celebração do Termo de Ajustamento de Conduta (TAC) ou do Termo de Ajustamento de Gestão (TAG) para possibilitar ao Poder Público deixar de sancionar uma empresa sujeita à sua regulação, para dela exigir compromissos de melhorias na prestação do serviço e a cessação da prática infracional que deu origem ao controle" (WILlEMAN, Flávio de Araújo. Termo de Ajustamento de Gestão nas Concessões: Conversibilidade das Sanções Administrativas Pecuniárias em Investimentos, 2012, p. 813).
} 


\section{CAPÍTULO 4 - NOÇÕES SOBRE UMA GESTÃO COORDENADA DE INTERESSES}

\subsection{Redução da atuação impositiva da Administração}

O Estado tem passado por um processo de reformulação do seu papel, que tende a deslocar o eixo de atuação impositiva para uma atuação coordenada, consensual, na qual o Estado atua em posição de diálogo e interação com a sociedade civil. A busca pela redução de privilégios e exclusividades se impõe tanto na gestão econômica, política, social como ambiental. Essa transformação estatal, por um lado, é reflexo da necessidade de conferir-se maior legitimidade às ações estatais. Por outro lado, representa uma exigência de melhor equalização dos múltiplos e mais diferenciados interesses que estiverem em causa.

A atuação estatal unilateral e impositiva é colocada em xeque a partir do momento em que diversas posições e interesses tentam fazerem-se prevalentes, fugindo da clássica visão monista de interesse público. A pressão por participação, por transparência, por razoabilidade e proporcionalidade nas decisões aliada a uma multiplicidade de interesses impõe métodos mais participativos. A decisão estatal terá de compor diversos interesses, em alguns casos antagônicos entre si, não podendo mais se fundamentar apenas no “interesse público”, de maneira abstrata, pois terá de explicar qual o interesse especificamente irá satisfazer ${ }^{344}$. Nesse sentido leciona FLORIANO DE AZEVEDO MARQUES NETO: “(...) o processo de fragmentação social e política também solapa o poder decisório, na medida em que (...) põe à prova a exclusividade da autoridade ${ }^{345, "}$.

A participação na tomada de decisões da administração é fundamental para que sejam mais bem fundamentadas e atreladas aos anseios sociais. Isso não quer dizer que todos os interesses serão igualmente atendidos, pois é evidente que em algumas situações isso não será possível. O que se pretende com esse novo modo de atuação estatal é que os interesses em causa sejam observados e efetivamente avaliados no momento da decisão de. Isso não deve se dar apenas de modo formal, mas de modo efetivo.

O Estado passa a atuar não como autoridade superior, mas como autoridade que representa interesses sociais. Ou seja, uma autoridade que não perde em poder, mas que

\footnotetext{
${ }^{344}$ Essa justificação e até mesmo transparência da autoridade estatal também possibilita o controle de suas ações. Quando os mais diversos interessados participam mais difícil se torna a influência de um interesse isolado interferir no processo de decisão.

${ }^{345}$ Regulação estatal e interesses públicos, 2002, p. 128.
} 
usa o seu poder de modo instrumental, ou seja, para a consecução das atividades administrativas e para impor a sua própria vontade, como se superior o pudesse ser.

A aproximação da atuação pública e privada permite afastar-se da clássica relação de subordinação por parte dos particulares e hierarquicamente superior (e unilateral) por parte do poder público. Essa conjugação de esforços permite uma atuação coordenada e que tende a ser mais efetiva, porque envolve diferentes perspectivas e esforços conjuntos. Nos dizeres precisos de DIOGO DE FIGUEIREDO MOREIRA NETO:

"A conjugação de todos os esforços, particulares e públicos, a criação de um sistema coordenativo e subordinativo destinado a desenvolver e harmonizar o emprego de meios de toda ordem, visando à preservação do meio-ambiente, necessitam de atuação concentrante e concertante do Estado e, porque esta atuação deve se dar dentro dos balizamentos jurídicos de valor, decorre e justifica-se a necessidade de um sistema de instrumentos legais ${ }^{346, "}$.

É considerando esse contexto que as obrigações e deveres de planejamento, gestão, regulação e fiscalização de políticas públicas relacionadas à proteção ambiental (e, mais especificamente, à gestão de resíduos) devem ser efetivadas. Ou seja, mediante a atuação conjunta de particulares (que podem ser empresas ou os cidadãos individualmente considerados), e do poder público na efetivação das ações e instrumentos aptos a efetivar as políticas ambientais.

\subsubsection{Incentivos práticos às formas dialógicas de relação}

A implementação da PNRS e especificamente da logística reversa impõe uma forma mais dialógica de relacionamento entre os cidadãos, os agentes econômicos e o Estado. Todos são convocados a refletir e a participar da consecução das políticas públicas e do gerenciamento estatal. Como leciona FERNANDO DIAS MENEZES DE ALMEIDA: “... a Administração consensual, notadamente por suas virtudes democráticas, pode até mesmo exercer uma função de recuperação de valores cívicos e da dimensão coletiva da ação dos indivíduos em sociedade, melhor os envolvendo nos assuntos da Administração e do Estado ${ }^{347,}$.

\footnotetext{
${ }^{346}$ Introdução ao Direito Ecológico e ao Direito Urbanístico, 1975, p. 24.

${ }^{347}$ Mecanismo de consenso no Direito Administrativo, 2008, p. 349.
} 
$\mathrm{O}$ art. $3^{\circ}$, inc. VI da PNRS visa a garantir mecanismos e procedimentos que possibilitem à sociedade a participação efetiva nas políticas públicas relacionadas aos resíduos sólidos tanto por meio de obtenção de informações como pela formulação de questionamentos e sugestões. Também se prevê a participação social na formulação dos planos nacionais, por meio de audiências e consultas públicas (art. 15, parágrafo único), além das entidades representativas dos consumidores ou das entidades interessadas poderem participar nos processos de formulação de acordos setoriais e nos grupos de acompanhamento da logística reversa articulados pelo CORI.

Os estímulos à implementação da política nacional de resíduos sólidos podem ser variados. A Administração tem a possibilidade de atuar tanto impositiva quanto consensualmente. No primeiro caso, a lei pode prever a adaptação das condutas dos particulares por meio da imposição de obrigações, proibições e sujeições ou ainda pela aplicação de sanções, como multas, compensações e indenizações. Na segunda hipótese, há os instrumentos colaborativos, sem os quais se dificultaria e, em alguns casos, obstaculizaria a efetivação dessa pauta política ${ }^{348}$.

Dentre os métodos colaborativos é possível se celebrar parcerias público-privadas, consórcios ou convênios públicos. Nesses casos há aportes de recursos e a conjugação de esforços tanto dos particulares como da Administração Pública para a efetivação da gestão de resíduos, o que permite o desenvolvimento de atividades mais complexas, que, muito provavelmente, não poderiam ser desenvolvidas de modo individualizado.

A logística reversa é um instrumento um pouco diferenciado da parceria-público privada, primeiro porque a participação do particular não se dá apenas na execução, mas também na formulação e escolha das ações a serem executadas. Em segundo lugar, há um dever jurídico de atuação por parte dos fabricantes, comerciantes, importadores e distribuidores.

A maior abertura a participação social talvez decorra dessa circunstância de a logística reversa ser um instrumento imposto pela lei que modula a atuação da iniciativa

\footnotetext{
${ }^{348}$ Aqui se optou em dividir os instrumentos em repressivos e colaborativos por se compreender que outras subdivisões estão abarcadas nessas classificações, mas RAMÓN MARTÍN MATEO alude a cinco tipos de instrumentos: "Limitativos, que restringem a vontade dos sujeitos que devem adaptar suas condutas aos imperativos das normas que regem a matéria (...) Ampliativos, consistentes em subvenções, ajudas fiscais, concessões, empréstimos privilegiados, compras preferenciais, Cooperativos, que implica tanto a Administração como os particulares (...) Repressores, consistentes em multas e outras sanções; Fiscais e Territoriais, dirigidos a localização adequada das instalações de tratamento de resíduos de acordo com os planos aprovados” (tradução livre). (Nuevo ordenamiento de la basura, 1998, p. 57).
} 
privada, seja no sentido de reduzir o volume de resíduos produzidos, ou de reaproveitar os resíduos, ou de propiciar melhor práticas socioambientais.

Embora exista esse lado impositivo da logística reversa, ela não deixa de ser um método de colaboração, visto que a formulação do modelo adotado poderá se dar, como tem se dado, de maneira consensual, via formulação de acordos setoriais e não propriamente por regulamentos.

O Decreto 7.404/2010, que regulamentou a Lei 12.305/2010, dispõe sobre a importância da cooperação de todos os setores para a efetivação da logística reversa. O art. $7^{\circ}$ assim dispõe: “O Poder Público, o setor empresarial e a coletividade são responsáveis pela efetividade das ações voltadas para assegurar a observância da Política Nacional de Resíduos Sólidos e das diretrizes e determinações estabelecidas na Lei $n^{\circ}$ 12.305, de 2010, e neste Decreto".

\subsection{As dimensões da logística reversa}

O tema da logística reversa envolve diversos interesses (econômicos, ambientais, sociais e pode até se acrescentar culturais), o que faz com que possa ser abordado sob uma multiplicidade de enfoques. Aliás, a análise sobre a política de resíduos é comumente enfrentada para além da área jurídica, visto que contempla enfoques de áreas biológicas e sociológicas, por exemplo.

No campo jurídico também é possível examinar o tema sob enfoques variados. Tem-se a perspectiva ambiental, que irá se preocupar com questões de proteção ao meio ambiente, como a redução da utilização de recursos naturais, volume de resíduos descartados, áreas onde se instalarão os aterros sanitários etc. Há o enfoque mais econômico abrangente tanto dos meios de produção quanto dos impactos pela má gestão dos resíduos. Outro recorte refere-se aos aspectos social e cultural, no qual se pode tratar, dentre outras questões, daquelas relativas aos padrões de consumo, à formação de cooperativas, ONGs ou até mesmo o papel dos catadores.

A identificação dessas dimensões deve servir de balizamento para a determinação do planejamento da logística reversa. Uma visão estratégica adequada deve se preocupar com todos os fatores que podem impactar a atividade. 


\subsubsection{A dimensão ambiental da logística reversa}

No tocante ao aspecto ambiental tem-se a preocupação com o acúmulo de resíduos no meio ambiente, que geram diversos tipos de danos ambientais e danos à saúde pública.

A logística reversa envolve um processo de rediscussão do desenvolvimento econômico e o meio ambiente, sob a perspectiva de que devem ser buscadas opções que possam ser compatíveis com o meio ambiente. Não se pretende com isso restringir o desenvolvimento econômico, mas possibilitar uma vertente desse desenvolvimento que seja sustentável, ou seja, que permita a continuidade em longo prazo. Nesse sentido IZABEL CRISTINA BRUNO BACELLAR ZANETI explica que o objetivo não é “(...) inviabilizar o processo de desenvolvimento, mas a de rediscuti-lo em função do meio ambiente. A verdadeira escolha não é entre desenvolvimento e meio ambiente, mas, entre as formas de desenvolvimento, sensíveis ao meio ambiente ou não ${ }^{349}$.”.

A dimensão ambiental pressupõe a incorporação de questões ambientais por parte das empresas, que assim possibilite a valorização das questões ambientais no desenvolvimento das atividades econômicas e a tomada de decisão do consumidor vinculada à escolha de produtos mais adequados do ponto de vista ambiental, "produtos verdes $^{350}$,"

A escolha do modelo de logística reversa depende do conhecimento prévio da realidade local em que será aplicado, sob pena de se comprometer a eficiência dessa medida. É preciso obter-se informações do relevo do local, porque isso influencia na escolha do modal para transporte de resíduos e na escolha dos sistemas de informatização de coleta $^{351}$. A depender das características de cada localidade, como pluviosidade, composição do solo, qualidade do ar, clima, existência de mananciais, determina a escolha de áreas disponíveis para aterragem (ou inexistindo as possíveis alternativas) e a viabilidade de construção das infraestruturas necessárias para outros tratamentos, como usinas de aproveitamento energético.

O projeto do Plano Nacional de Resíduos Sólidos, que ainda encontra-se em versão preliminar, dispõe sobre o cumprimento de metas na gestão de resíduos, que se

\footnotetext{
${ }^{349}$ Educação ambiental, resíduos sólidos urbanos e sustentabilidade. Um estudo de caso sobre o sistema de gestão de Porto Alegre/RS, 2003, p. 34.

${ }^{350}$ PAIVA, Teresa; PROENÇA, Reinaldo. Marketing Verde. Coimbra: Almedina, 2011, p. 68.

${ }^{351}$ Sobre o tema da roteirização da coleta domiciliar, confira-se: BARROS, Regina Mambeli. Tratado sobre resíduos sólidos. gestão, uso e sustentabilidade, 2013, p. 77-87.
} 
relacionam com essa dimensão ambiental, como fechamento dos lixões ${ }^{352}$, recuperação de áreas de lixão - mediante captação de gases, tratamento do chorume, drenagem da massa pluvial, cobertura vegetal do solo e redução de resíduos recicláveis em aterros ${ }^{353}$.

\subsubsection{A dimensão econômica da logística reversa}

A perspectiva econômica envolve analisar fatores relacionados à organização produtiva, como estratégias de concepção dos produtos, de desenvolvimento de novas tecnologias, o planejamento operacional, a organização informacional etc. Assim como, a análise dos deveres e obrigações impostos aos agentes econômicos e os custos de implementação, execução e aperfeiçoamento das atividades de logística reversa.

A forma de concepção dos produtos, o modelo de gerenciamento do ciclo de vida do produto, a eficiência operacional (de coleta, transporte, armazenagem, tratamento e destinação final), as tecnologias utilizadas ${ }^{354}$, dentre outros fatores, influenciam a maior ou menor redução dos custos da empresa com o desenvolvimento da logística reversa. Desse modo, a atratividade da logística reversa dependerá das características de organização estratégica de cada empresa.

A Lei 12.305/2010 impõe a alguns setores a obrigação de implementar a logística reversa, o que exige ainda mais a participação ativa do setor econômico na formulação de sua modelagem.

\subsubsection{Dever jurídico de gestão do ciclo de vida dos produtos: "responsabilidade compartilhada”}

A todos os agentes que possam estar envolvidos na geração de resíduos sólidos, como fabricantes, importadores, distribuidores, comerciantes, consumidores e titulares dos

\footnotetext{
${ }^{352}$ Nos lixões os resíduos encaminhados são depositados a céu aberto. Não há qualquer tipo de tratamento técnico. Há um risco à saúde pública muito grande com a proliferação de doenças, afinal não existe nenhum tipo de tratamento ou controle técnico. Também não há um estudo específico do local onde está sendo manejado o descarte. Na realidade brasileira, os lixões ainda se constituem como alternativas concretas para o depósito de resíduos, em que pese a meta de eliminação desses espaços, conforme previsto no inc. V, art. 15 da Lei 12.305/2010. O Senado aprovou a Medida Provisória 651/2014 para estender o prazo para o fechamento dos lixões até 2018, no entanto, a proposição foi vetada pela Presidência da República.

${ }^{353}$ Informações disponíveis em:

http://www.sinir.gov.br/documents/10180/12308/PNRS_Revisao_Decreto_280812.pdf/e183f0e7-52554544-b9fd-15fc779a3657. Acesso em 12.11.2014.

${ }^{354}$ Alguns setores, principalmente aqueles que investem em pesquisas e no desenvolvimento de novas tecnologias, tendem a desenvolver processos bastante eficientes e a gerarem receitas consideráveis com a logística reversa. Estima-se que o mercado secundário de eletroeletrônicos americano movimente cerca de 15 bilhões anualmente. Além de oportunidade de receitas, a reutilização ou a revendam permitem se reduzir os gastos com a disposição final de resíduos. Para maiores informações consulte-se: GREVE, Curtis; DAVIS, Jerry. Reverse Logistics. Recovering Lost Profits by Improving, 2012, p. 8.
} 
serviços públicos de limpeza urbana e de manejo de resíduos sólidos, são atribuídos deveres para a gestão do ciclo de vida do produto. A lei menciona o termo “responsabilidade" compartilhada pelo ciclo de vida, mas aqui deve entender-se a responsabilidade no sentido de imposição de obrigações e não no sentido de responsabilização civil ${ }^{355, \text { " }}$

A leitura dos incisos elencados no art. 30 da Lei 12.035/2010, que trata da responsabilidade compartilhada indicam o seguinte:

"I - compatibilizar interesses entre os agentes econômicos e sociais e os processos de gestão empresarial e mercadológica com os de gestão ambiental, desenvolvendo estratégias sustentáveis; II promover o aproveitamento de resíduos sólidos, direcionando-os para a sua cadeia produtiva ou para outras cadeias produtivas; III - reduzir a geração de resíduos sólidos, o desperdício de materiais, a poluição e os danos ambientais; IV - incentivar a utilização de insumos de menor agressividade ao meio ambiente e de maior sustentabilidade; $V$ - estimular o desenvolvimento de mercado, a produção e o consumo de produtos derivados de materiais reciclados e recicláveis; VI - propiciar que as atividades produtivas alcancem eficiência e sustentabilidade; VII - $\underline{\text { incentivar }}$ as boas práticas de responsabilidade socioambiental”.

Resta evidente que a lei impõe deveres jurídicos (compatibilizar, promover, reduzir, incentivar, estimular, propiciar). Esses deveres impostos pela Lei 12.305/2010 se relacionam com ações que visam a possibilitar a gestão e a prevenção do ciclo de vida dos produtos, assim como estimular práticas ambientais mais eficientes e sustentáveis.

A responsabilidade em si impõe-se apenas complementarmente, ou seja, em caso de verificar-se alguma conduta que viole os deveres impostos. A responsabilidade, numa definição mais técnica, pressupõe o descumprimento de um dever (efetivo ou potencial) ${ }^{356}$.

Ao que se pode aludir a lei trata de uma responsabilização civil pela gestão inadequada de resíduos sólidos no pós-venda ou no pós-consumo. Nesse caso há o dever de gestão ambiental adequada e o correspondente descumprimento, que é passível de imputação de responsabilidade civil. Essa responsabilização não precisa ficar adstrita à

\footnotetext{
${ }^{355}$ Nessa linha, TASSO ALEXANDRE RICHETTI PIRES CIPRIANO explica: "No caso brasileiro, essa responsabilidade pode ser entendida como o plexo de deveres impostos aos geradores de resíduos com vistas a assegurar a prevenção e gestão dos resíduos que produzam, devendo eles arcar com os custos correspondentes às ações necessárias a levar a cabo essas tarefas. (A juridificação dos resíduos no Brasil. In: PHILLIP JR., Arlindo; PASSOS DE FREITAS, Vladimir; SPÍNOLA, Ana Luiza Silva. Direito Ambiental \& sustentabilidade, no prelo).

${ }^{356}$ Nesse sentido confira-se: JUSTEN FILHO, Marçal. Curso de Direito Administrativo. 10 ed., 2014, p. 1321-1322.
} 
minimização de danos, mas juntamente é possível (e até mesmo desejável) que sejam adotadas medidas de cunho cautelar, que possibilitem se atuar na prevenção de danos ${ }^{357}$.

Nessa linha TERESA ANCONA LOPEZ enfatiza que o princípio da precaução tem aplicabilidade ampla “(...) em questões que envolvem riscos de danos ao meio ambiente como um dever geral de cautela que se impõe na incerteza científica de danos”, o que decorre principalmente "em função do bem juridicamente tutelado, qual seja, o meio ambiente ecologicamente equilibrado, fundamental para a garantia do direito à vida das presentes e futuras gerações ${ }^{358, "}$

Sobretudo, em matéria ambiental, é mais relevante se evitar um dano do que obter o ressarcimento ou algum tipo de compensação. Afinal, a reconstituição de um ambiente natural nas suas condições originais pode levar anos ou até mesmo décadas para se recompor. Há grandes chances de que seja impossível de se recompor toda a sua complexidade original.

A prevenção assume um papel relevante nos casos em que a função ressarcitória não seja suficientemente adequada. Afinal, em matéria ambiental é sempre muito frequente que a indenização pecuniária não seja mensurável. Há situações que não são passíveis de reparação, sendo imprescindível a adoção de medidas preventivas ${ }^{359}$. No entanto, para haver a responsabilização com base na prevenção é necessário que existam critérios que fundamentem o receio de descumprimento dos deveres impostos pela lei.

Havendo elementos que ensejem a responsabilização é possível que exista uma responsabilidade solidária entre todos os agentes que atuam na gestão de resíduos, sejam fabricantes, comerciantes, distribuidores, agentes públicos e eventualmente consumidores. Afinal a todos esses agentes são impostos alguns deveres.

O critério para se aplicar a responsabilidade solidária deve estar ligado à existência de uma relação de causalidade entre o dano e o comportamento dos agentes

\footnotetext{
357 As medidas preventivas podem ser dividas em primárias, quando se destinarem a evitar um dano, ou secundárias, nos casos em que se adotam medidas para não se agravar um dano já ocasionado. Mesmo que o Poder Público se omita no dever de fiscalizar (medida de primeiro grau), ainda assim poderá adotar medidas de segundo grau, considerando-se, por exemplo, os casos em que um poluidor não atue de modo suficientemente adequado em relação à poluição ocasionada ou até mesmo na hipótese dele não atuar. ARAGÃO, Maria Alexandra. O princípio do poluidor pagador como princípio nuclear da responsabilidade ambiental no direito europeu, 2009, p. 108-109. Disponível em:

http://www.estig.ipbeja.pt/ ac direito/ICJP_ebook_ResponsabilidadeCivilporDanoAmbiental.pdf. Acesso em 15.09.2014.

${ }^{358}$ Princípio da precaução e evolução da responsabilidade civil, 2010, p. 235.

${ }^{359}$ Princípio da precaução e evolução da responsabilidade civil, 2010, p. 121.
} 
envolvidos na produção dos danos ${ }^{360}$. Ou seja, aqueles que, em maior ou menor medida, contribuem para a produção de danos devem ser responsabilizados. Isso, sempre que possível, deve se dar na proporção que cada qual tenha contribuído para ocasionar o dano $^{361}$.

\subsubsection{2 $\mathrm{O}$ entendimento do STJ acerca da responsabilização pela gestão de resíduos}

O STJ no Recurso Especial 1.373.788, de relatoria do Min. Paulo de Tarso Sanseverino, julgado em 06.05.2014, tratou da responsabilização de empresa pelas queimaduras sofridas por pessoa que teve contato com os resíduos tóxicos que foram despejados de modo inadequado.

Nesse julgado houve o reconhecimento de nexo de causalidade, visto que o perito criminal atestou que os produtos da empresa (restos de caldeira) foram depositados no mesmo local em que havia resíduos orgânicos, gerando uma combustão espontânea que elevou a temperatura do solo e ocasionou as queimaduras do autor da ação.

A Recorrente alegou a existência de placas indicando resíduos orgânicos no local. Mas reputou-se que isso não seria suficiente para excluir a responsabilidade, visto que em matéria ambiental a responsabilidade deve ser objetiva e fundada na teoria do risco integral, independentemente do dano afetar indistintamente toda a coletividade ou apenas determinados direitos individuais. Além do que, como mencionado pela sentença de origem, o despejo de resíduos tóxicos contamina o solo e o lençol freático, o que não se afasta mediante a existência de placas de sinalização. Então, houve o descarte inadequado dos resíduos e como consequência o dano a um terceiro.

O STJ decidiu que a responsabilização é objetiva, mas é imprescindível se delimitar o vínculo existente entre a atividade realizada e o dano ocasionado e os consequentes deveres jurídicos subjacentes, os quais devem demonstrar a violação do dever de diligência, cujo descumprimento ocasionou ou potencializou os efeitos danosos.

\footnotetext{
${ }^{360}$ Essa concepção é desenvolvida por CALIXTO DÍAZ-REGAÑÓN GARCÍA- ALCALÁ a propósito da análise do contexto europeu e em especial das Leis espanholas 42/75 e 20/86. O autor destaca que: “'Responsáveis’ solidários seriam tanto os produtores iniciais de resíduos com os posteriores gestores ou eliminadores dos mesmos a quem os primeiros tenha cedido essas substâncias” - tradução livre (El régimen jurídico-privado de los residuos, 1998, p. 165-166).

361 SIDNEY GUERRA aponta que um dos traços distintivos entre a responsabilidade civil e a responsabilidade compartilhada é a imposição da responsabilização na medida da colaboração para a produção do dano. Nos dizeres do autor: “(...) a responsabilidade compartilhada importa numa versão otimizada da responsabilidade comum, que, em regra, sanciona os sujeitos diretamente ligados ao evento danoso, sem atentar sobre as condutas de todos os demais” (Resíduos Sólidos, 2012, p. 91).
} 
Entendeu-se ainda que, de qualquer modo, quando existirem provas científicas de que os riscos possuem alta probabilidade de ocorrência, podem ser impostas medidas de cunho preventivo $^{362}$, que se configuram obrigações, deveres jurídicos a serem observados para se evitar o dano ambiental ${ }^{363}$. Isso em decorrência dos princípios da precaução e da prevenção $^{364}$.

\subsubsection{Responsabilidade Alargada do Produtor - Extended Producer Responsability}

A figura da responsabilidade compartilhada da PNRS encontra semelhanças com a figura da Extended Producer Responsability (Responsabilidade Alargada do Produtor), que também visa a práticas que permitam o melhor aproveitamento dos resíduos e de ações que sejam mais adequadas do ponto de vista ambiental. No entanto, a EPR visa apenas à responsabilização do fabricante (e não de todos os agentes participantes da cadeia produtiva e de consumo) pelos impactos ambientais provocados pelo ciclo de vida do produto $^{365}$.

A EPR teve origem no programa de reciclagem de embalagens criado na década de 90 na Alemanha e que visava à redução, recolhimento, reutilização, reciclagem e destinação final adequada de embalagens descartadas ${ }^{366}$.

\footnotetext{
${ }^{362}$ ARAGÃO, Maria Alexandra de Souza. O Direito dos Resíduos, 2003, p. 11.

${ }^{363}$ Para alguns autores, contudo, essa imposição de deveres jurídicos preventivos configurar-se-ia uma "reorientação da função da responsabilidade civil que deve assumir uma feição cada vez precaucional, em nome da proteção ambiental” e não propriamente em deveres jurídicos. (BAHIA, Carolina Medeiros. A responsabilização civil ambiental: seus dilemas em face da sociedade de risco e a problemática da prescrição da pretensão reparatória, 2010, p. 212).

${ }_{364} \mathrm{Tal}$ como enfatizado por ANNELISE MONTEIRO STEIGLEDER tais princípios devem ser diferenciados. O princípio da precaução se relaciona a situações que exigem cautela diante de perigos desconhecidos, mas que são prováveis. Já o princípio da prevenção pressupõe riscos conhecidos, porque já identificados ou já ocorridos. Nesse caso deseja-se evitar o dano ou sua repetição. (STEIGLEDER, Annelise Monteiro. Responsabilidade Civil Ambiental. As dimensões do dano ambiental no direito brasileiro. 2. ed., 2011, p. 164).

${ }^{365}$ Há autores que questionam a ausência de inclusão no conceito do ente público e também dos consumidores, tal como HANS WIESMETH e DANNIS HÄCKL. Nessa linha, confira-se: "Se uma política de EPR procura integrar os sinais associados a um produto ao longo da cadeia do produto, por isso devem ser excluídos dos municípios 'em particular, e os consumidores e outras partes interessadas, em geral, a partir da consideração? As autarquias podem desempenhar um papel decisivo na promoção de um projeto para o meio ambiente, por exemplo, a organização de gestão de resíduos de uma forma, que suporta ou alivia atividades de reciclagem" (tradução livre). (How to successfully implement extended producer responsibility: considerations from an economic point of view, 2011. Disponível em: http://wmr.sagepub.com/content/29/9/891. Acesso em 03.12.2014.

366 MOREIRA, Danielle de Andrade. Responsabilidade ambiental pós-consumo: da prevenção à reparação de danos, 2008, p. 147.
} 
A OECD define a responsabilidade alargada do produtor (EPR) como:

“(...) uma abordagem política ambiental em que a responsabilidade de um produtor de um produto é estendida para a fase pós-consumo do ciclo de vida de um produto. Uma política de EPR é caracterizada pela: (1) transferência de responsabilidade (física e / ou economicamente; total ou parcialmente) ao produtor (...); e [pela] 2) concessão de incentivos aos produtores para ter em conta as considerações ambientais na concepção dos seus produtos. Enquanto outros instrumentos de política tendem a atacar um único ponto da cadeia, a EPR procura integrar os sinais relacionados com as características ambientais de produtos $e$ processos de produção em toda a cadeia do produto ${ }^{367 \text { ", (tradução }}$ livre).

O conceito do EPR é desenvolvido como forma de afastar a isenção dos fabricantes em relação às responsabilidades que do descarte de seus produtos, mas não fica restrita ao fim de vida útil dos produtos, pois todas as fases da cadeia produtiva são enfocadas.

A obrigação de diligência em relação aos produtos inicia-se desde a sua concepção e da escolha de seu design. Afinal, a escolha do material, das quantidades utilizadas, da facilidade de reciclagem, durabilidade influenciam na gestão dos resíduos.

O desenvolvimento do EPR possibilitou a estruturação da logística reversa como uma responsabilidade/obrigações dos agentes privados e não apenas atribuível ao poder público. Para PAULO ROBERTO LEITE:

“Contrariamente às primeiras legislações do início dos anos 1970, que tendiam a responsabilizar os governos locais pelo impacto ambiental dos resíduos sólidos, uma das idéias básicas que orientam essas legislações atualmente é responsabilizar os fabricantes, direta ou indiretamente, pelo impacto de seus produtos no meio ambiente, por meio de leis dirigidas às etapas de reciclagem ou, indiretamente, por meio de proibições de disposição em aterros sanitários, de uso de certos tipos de embalagens práticas, até a devida estruturação dos canais reversos etc. Essas legislações têm sua origem nas idéias da denominada filosofia de EPR (extended product responsability) ${ }^{368,}$.

${ }^{367}$ Informações disponíveis em:

http://www.oecd.org/env/tools-evaluation/extendedproducerresponsibility.htm. Acesso em 03.12.2014.

${ }^{368}$ Logística reversa. Meio Ambiente e Competitividade. 2. ed., 2009, p. 139. 


\subsubsection{Limites à imposição de deveres para cumprimento da logística reversa}

É possível que sejam impostas restrições ao exercício de determinadas atividades. Isso deve ser feito dentro de certos limites, para que não se configure uma violação à liberdade de livre iniciativa. Por tal razão, a imputação de deveres precisa ser feita no tocante ao modo de operacionalização das atividades econômicas, não sendo possível que se configure uma limitação ao seu exercício ${ }^{369}$. Melhor explicando: algumas atividades em razão das suas características podem envolver a violação ou a afetação mais acentuada de valores cuja proteção deve ser elevada, como se trata as questões ambientais, de saúde publica etc. Então se torna possível impor algumas restrições ou condicionamentos para o exercício dessas atividades ${ }^{370}$.

Os órgãos responsáveis pela implementação da logística reversa devem atuar de modo cauteloso em relação à imposição de obrigações e deveres. As medidas adotadas devem ser sempre proporcionais aos fins que se pretende atingir. A imposição de medidas de aplicabilidade prática limitada poderá prejudicar os objetivos atingidos e enfraquecer a consolidação a PNRS. Deve ainda haver razoabilidade na imposição de exigências às empresas, porque a logística reversa não pode se tornar um instrumento de constrição de direitos dos particulares.

Além disso, a logística reversa é um instrumento que como visto tem de ser implantado mediante um adequado planejamento, mediante a previsão de metas progressivas (art. 56 da PNRS).

A lei prevê alguns instrumentos para viabilizar a logística reversa, como acordos setoriais e termos de compromisso, os quais conterão a modelagem mais adequada para cada setor empresarial. Desse modo, a imposição unilateral de medidas, como por meio de regulamentos, deve ser utilizada o mínimo possível e, via de regra, quando não houver o consenso entre as partes e a potencialidade de dano ao meio ambiente.

As medidas de proteção ambiental e estímulo à valorização dos resíduos necessitam de planejamento e de estudos de viabilidade técnica e econômica. Não parece ser o objetivo da lei a imposição unilateral e isolada de obrigações a apenas algumas empresas, muito embora a lei seja mais rigorosa em relação a determinados setores ${ }^{371}$. A

\footnotetext{
${ }^{369}$ Inclusive porque a livre iniciativa é um direito fundamental, inerente a nossa ordem econômica, conforme previsto no art. 170, caput da CF/88.

370 SANTOS, António Carlos dos; GONÇALVES, Maria Eduarda; MARQUES, Maria Manuel Leitão. Direito Económico. 4. ed., 2001, p. 228.

${ }^{371}$ Esses setores são aqueles nos quais se impõe como obrigatória a logística reversa, como de pneus, pilhas e baterias, lâmpadas, eletroeletrônicos, embalagens, óleos lubrificantes e agrotóxicos.
} 
noção que se depreende do texto da lei é, portanto, a de criar um sistema em que todas as empresas, consideradas de modo setorizado, atuem na gestão de resíduos ${ }^{372}$.

Nesse sentido, compete, por exemplo, ao poder judiciário apreciar a responsabilidade de empresas quanto ao cumprimento de acordos setoriais ou termos de compromisso de que sejam signatárias. Nos casos em que houver dano provocado por uma empresa isoladamente a responsabilidade será individualmente apurada.

Quando não houver nenhum tipo de acordo ou termo tratando do tema, a imposição isolada de determinações, que impliquem alteração do modo produtivo das empresas, precisa estar balizada em lei ou em regulamentos para se evitar a imposição de medidas que tenham caráter limitador da livre concorrência.

\subsubsection{Limitações impostas pelo Poder Judiciário: análise da Ação Civil Pública 364/2000 (PR)}

Um caso importante a partir do qual se pode avaliar a imposição de limitações pelo Poder Judiciário é a Ação Civil Pública 364/2000, que tramitou na $4^{\text {a }}$ Vara Cível de Curitiba, proposta em face de empresa engarrafadora de refrigerantes, para se questionar a ausência de destinação final das embalagens utilizadas para envase de seus produtos ${ }^{373}$.

A parte autora, uma Associação de Defesa e Educação Ambiental, requereu nessa ACP: (i) a suspensão da comercialização dos produtos em embalagens PET; (ii) o recolhimento das embalagens usadas, onde quer que se encontrem, e (iii) a apresentação de um cronograma de substituição do material na linha de produção, sob pena de multa diária.

A decisão de primeiro grau, em 11.10.2001, julgou improcedente a ação. Acertadamente destacou-se que o pedido da parte autora é “nobre visando a proteção do meio ambiente mas não da maneira como pretende pois, proibindo a requerida de comercializar seus produtos em embalagens PET, certamente acarretará grandes prejuízos, de difícil ou impossível reparação”. Além do argumento de dano de difícil

\footnotetext{
${ }^{372}$ É evidente que sempre haverá aquela parcela que atua na informalidade, a exemplo do que ocorre com o pagamento de tributos, mas essa deve ser uma situação excepcional.

${ }^{373}$ Na Dinamarca, em 1981, foi publicada uma lei que proibia o envase de cervejas e outras bebidas em recipientes metálicos, impondo-se a uniformização de embalagens de vidro, que facilitariam o armazenamento, recolha e reutilização. Havia até um sistema de reembolso ao consumidor pela devolução das garrafas utilizadas. Embora essa lei tenha sido muito criticada por dificultar as relações comerciais no âmbito comunitário e também por ser considerada excessiva, o Tribunal de Justiça não reconheceu que haveria excesso na disposição legal, que tinha por objetivo a proteção do meio ambiente. Essa foi inclusive uma das primeiras decisões que se fundamentou na proteção ao meio ambiente como critério decisório. (CANOTILHO, José Joaquim Gomes; LEITE, José Rubens M. Direito Constitucional Ambiental Brasileiro. 3. ed., 2010, p. 55). Note-se que até seria possível haver uma regulamentação sobre o tipo de material mais adequado para o envase, mas isso deve ser previsto em lei. A imposição isolada a uma determinada empresa imputa custos que afetam o direito de concorrência.
} 
reparação a ser imputado à empresa, acrescente-se que não há (como não havia a época da interposição da ação) lei que proíba a utilização de embalagens PET para envase. Ademais e como destacado na sentença, diversos segmentos da indústria, no mundo todo, se utilizam dessas embalagens, como empresas farmacêuticas, de cosméticos, produtos de limpeza etc.

A utilização de determinado tipo de embalagem PET não é causa de danos ao meio ambiente, mas sim a ausência de destinação ou disposição finais. Não há risco que decorra da utilização desse material, ao menos não há registros de estudos científicos nesse sentido, mas apenas do descarte inadequado.

No caso concreto o cerne do problema central era a empresa não possuir um plano de logística reversa, porque a ausência de tratamento adequado do resíduo acarreta a produção de dano ambiental decorrente de sua atividade ${ }^{374}$. Afinal qualquer tipo de resíduo que seja inadequadamente disposto pode gerar danos ambientais. Mas a questão não foi posta pela parte Autora apenas nesses termos, mas também no sentido de restrição da atividade econômica e de proibição da utilização de determinado material.

Há um nexo de causalidade entre a atividade e a poluição, visto que o ciclo de vida do produto não é fechado e permite que os resíduos contaminem o ambiente. Isso tanto é verdade que a própria Lei 12.305/2010 prevê a logística reversa como obrigatória para o setor de embalagens. No entanto, note-se que ação foi julgada na origem em 2001 e à época não havia a mesma concepção que se tem hoje em relação ao tratamento de resíduos. As primeiras disposições sobre gestão de resíduos surgiram principalmente no final da década de noventa. Ou seja, o tema ainda era bastante recente e mesmo hoje ainda se discute como implementar a logística reversa e a gestão adequada de resíduos. O setor de embalagens inclusive ainda nem chegou a um consenso sobre o modelo a ser efetivado. Até já existia na Lei do Estado do Paraná 12.493/1999 a previsão de que:

"As atividades geradoras de resíduos sólidos, de qualquer natureza, são responsáveis pelo seu acondicionamento, armazenamento, coleta, transporte, tratamento, disposição final, pelo passivo ambiental oriundo da desativação de sua fonte geradora, bem como pela recuperação de áreas degradadas" (art. $4^{\circ}$ ). Assim como, que a "a geração de resíduos sólidos, no território do Estado do Paraná, deverá ser minimizada através da adoção de processos de baixa geração de resíduos e da reutilização e/ou reciclagem de resíduos sólidos, dando-se

${ }^{374}$ A própria sentença de primeiro grau, ora analisada, destaca: “o lançamento de qualquer tipo de lixo na natureza causa danos ao meio ambiente”. 
prioridade à reutilização e/ou reciclagem a despeito de outras formas de tratamento e disposição final, exceto nos casos em que não exista tecnologia viável" (art. $3^{\circ}$, inc. I).

No entanto, daí não decorre que seja possível suspender as atividades da empresa sem a existência de lei que preveja essa hipótese ou propor um método de envase distinto, considerando-se que o mesmo método ainda poderá ser utilizado por outros agentes do mesmo setor, afrontando-se a livre concorrência. O que seria adequado era se fomentar a gestão adequada dos resíduos por parte da empresa, prevendo-se um prazo razoável para implementação da logística reversa, mas a suspensão da atividade ou a proibição de utilização de garrafas PET são medidas incabíveis sem previsão legal expressa. Com base na lei estadual poderia se exigir a reciclagem, mas não a suspensão da atividade.

Além disso, o poder público e os consumidores também teriam de assumir parte dessa responsabilidade. A própria sentença de primeiro grau destaca isso: “poder-se-ia, também imputar alguma responsabilidade aos órgãos públicos, por se omitirem quanto à publicidade para que atos dessa natureza não sejam praticados pela população e por eventual deficiência na coleta de lixo”. Esse também é o mesmo raciocínio da atual PNRS. Sob essa perspectiva caberia ainda se aferir se havia o descumprimento da coleta seletiva pelo Município, em razão das altas taxas de resíduos.

O TJPR, no julgamento da Apelação Cível 118.652-1 ${ }^{375}$, por unanimidade, reformou parcialmente a sentença de primeiro grau e impôs as seguintes determinações: (i) imposição à empresa engarrafadora de obrigação de fazer consistente na adoção de providências em relação à destinação final ambientalmente adequada das embalagens plásticas de produtos colocadas no mercado, em qualquer localidade que distribuir seus produtos, facultando-lhe a recolha e reutilização de ao menos $50 \%$ das garrafas que produzir anualmente e (ii) a utilização de parte dos seus gastos com publicidade em ações de educação e informação ambiental à população, sob pena de multa, com a imposição de destinação de $20 \%$ dos recursos financeiros.

Posteriormente, a empresa opôs embargos de declaração, os quais foram rejeitados pelo Tribunal. Desse modo, a empresa interpôs recurso especial, autuado sob o n. $684.753^{376}$, enfatizando o julgamento extra petita, visto que, a seu ver, foram impostas determinações não requeridas pela parte Recorrida, além de julgamento ultra petita pela

\footnotetext{
375 AC 118.652-1, 8 CC., rel. Des. Ivan Bortoleto, rev. Des. Antônio Renato Stapasson, j. 05.08.2002, DJ 26.08.2012.

${ }^{376}$ REsp 684.753 (PR), 4. T., rel. Min. Antonio Carlos Ferreira, j. 04.02.2014, DJ 18.08.2014.
} 
determinação de 20\% dos recursos financeiros em campanhas publicitárias. O recurso especial foi inadmitido na origem e teve seguimento no STJ por força do Agravo de Instrumento 553.373(PR), de relatoria do Min. LUIZ FUX.

O rel. Min. ANTONIO CARLOS FERREIRA destacou que a responsabilidade pós-consumo da empresa impõe-se por força do art. 170, inc. VI e art. 225 da CF/88, resoluções do CONAMA e algumas leis, visto que a época da ação ainda não havia sido editada a Lei 12.305/2010. Reputou-se que não houve julgamento extra petita porque a Recorrida pediu na inicial o recolhimento das embalagens, facultando o TJPR a adoção de procedimentos de reutilização e recompra de ao menos $50 \%$ e não da totalidade como inicialmente requerido. Também se afastou o julgamento ultra petita, pois um dos pedidos da ACP consistia na obrigação de fazer de iniciar campanha publicitária para difundir a ideia de recolhimento/troca das embalagens, determinando o TJPR apenas o quantitativo de investimento a ser feito pela Recorrente.

O relator ainda destacou que a responsabilização da Recorrente, impõe-se por fatos incontroversos da causa e os quais não foram prequestionados. Além do que reputa que a responsabilização decorre de fato notório - a poluição, cabendo a responsabilidade decorrente dos lucros que obtém da utilização de garrafas PET.

O Min. RAUL ARAÚJO propôs questão de ordem para que o julgamento fosse feito pela Corte Especial, considerando a relevância da matéria e do precedente para a formação da jurisprudência do STJ, divergindo no seguinte sentido:

"Mas, quero destacar a importância deste precedente para a jurisprudência que formaremos, pois estaremos responsabilizando o fabricante, não por danos causados ao meio ambiente em decorrência do processo produtivo, mas, sim, por dano pósconsumo, decorrente de resíduo do produto consumido, sem a existência de proibição legal na utilização, como insumo, da matéria prima tida por nociva, parte do fabricante. Quer dizer, se esse dano pós-consumo é considerado tão nocivo à coletividade, caberia ao poder público a edição de lei proibindo a utilização desses insumos na produção ou regulando o descarte do resíduo (...) Então, existem inúmeras situações diante das quais estaremos formando um precedente que afetará as relações econômicas de produção e consumo existentes ou realizadas no País, à revelia de disciplina legal, talvez em desigualdade com o que ocorre em outros países desenvolvidos” (grifou-se).

A questão de ordem, no entanto, não foi acolhida pelos Ministros do STJ. 


\subsection{Compatibilização das dimensões ambiental e econômica}

Não há como desvincular na realidade concreta os interesses ambientais, econômicos, sociais, culturais, porque tudo está, em maior ou menor medida, interconectado. As ações adotadas no ambiente econômico refletem nas relações sociais e ambientais. As separações e distinções são muito úteis para simplificar o entendimento da realidade, mas não se pode ignorar que as ações e os seus efeitos se relacionam como um todo.

Qualquer ação que seja executada no meio ambiente irá impactar de algum modo todos que nele estiverem inseridos. As relações sociais, econômicas e ambientais estão inter-relacionadas e produzem efeitos em todo o sistema. Desse modo, não há como se pensar em um desenvolvimento que seja sustentável sem levar em conta todos os aspectos e interesses envolvidos.

Em matéria de resíduos sólidos a sustentabilidade precisa ser pensada a partir do cotejo entre os instrumentos de preservação do meio ambiente e de desenvolvimento socioeconômico. Nessa linha confira-se o entendimento de ANA MARIA DE OLIVEIRA NUSDEO:

“(...) o tema da sustentabilidade (...) exige reflexões sobre o aperfeiçoamento dos instrumentos de que se vale a política ambiental de modo a garantir a efetividade de suas regras e a consecução da finalidade central: permitir a conciliação entre a garantia de qualidade de vida para os indivíduos e preservação de recursos ambientais ${ }^{377,}$.

A questão que se coloca é: como a proteção ambiental será efetivada? É possível se imporem limites? Sendo possível, quais limites podem ser impostos a essa relação de preservação ambiental e desenvolvimento socioeconômico?

O primeiro passo reputa-se que seja assumir que a relação entre meio ambiente e interesses econômicos não deve ser antagônica, como se a satisfação de um interesse eliminasse a possibilidade de atingimento do outro. Pelo contrário, o desenvolvimento de políticas públicas ambientais e econômicas depende da ponderação dos dois interesses para o atingimento de soluções satisfatórias, visto que ambos os setores são vitais para existência humana.

${ }^{377}$ O uso de instrumentos econômicos nas normas de proteção ambiental, Revista da Faculdade de Direito da Universidade de São Paulo, v. 101, p. 376, jan.- dez., 2006. 


\title{
Nessa linha ANTONIO BURGUÉS TERÁN e ALVARO LÓPEZ MORA
} destacam:

\begin{abstract}
"Os antagonismos entre o setor público e setor privado, entre a agricultura e a indústria e a falta de políticas de coordenação entre a agricultura e a indústria e a falta de políticas de coordenação entre o desenvolvimento da infraestrutura e a inversão, são fatores que em nada contribuem para a formação de um clima adequado para a produção (...) sem esse clima é impossível incrementar a produção de bens e serviços (...) e em

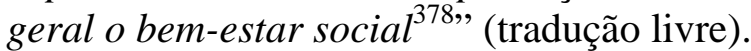

Os interesses devem mutuamente se controlar. Ou seja, só posso implementar as propostas de cunho econômico nos casos em que se compatibilizarem com o meio ambiente, mas essa compatibilização não é absoluta. Melhor explicando: quando o impacto ambiental não representar a degradação ambiental excessiva, poluição de difícil contenção ou recuperação será possível mitigar a questão ambiental, para que se possa empreender o desenvolvimento econômico e proporcionar qualidade de vida. Nessa linha RONALD H. COASE aduz: "O problema que enfrentamos ao lidar com ações que têm efeitos nocivos não é simplesmente de restringir os responsáveis por eles. O que tem de ser decidido é se o ganho de prevenir o dano é maior do que a perda que seria sofrida em outras áreas como resultado de impedir a ação que produz o dano ${ }^{379, " ~(t r a d u c ̧ a ̃ o ~ l i v r e) . ~}$

No entanto, esses limites não são aferíveis aprioristicamente. É necessária uma análise de cada caso concreto, o que envolve verificar as tecnologias disponíveis, a concepção cultural de cada povo e a degradação a ser provocada.

O Supremo Tribunal Federal já teve a oportunidade de se manifestar na ADPF 101 sobre a compatibilização de interesses econômicos e ambientais, um caso que envolvia a importação de pneus usados ${ }^{380}$. A rel. Min. CÁRMEN LÚCIA destaca a relevância da harmonização de interesses:

"Adequação da arguição pela correta indicação de preceitos fundamentais atingidos, a saber, o direito à saúde, direito ao meio ambiente ecologicamente equilibrado (arts. 196 e 225 da

\footnotetext{
${ }^{378}$ ¿Apertura por apertura o desarrollo sostenido?, n. 55, 1996, p. 25.

${ }^{379}$ Confira-se o original: "The problem which we face in dealing with actions which have harmful effects is not simply one of restraining those responsible for them. What has to be decided is whether the gain from preventing the harm is greater than the loss which would be suffered elsewhere as a result of stopping the action which produces the harm” (The problem of Social Cost, 1960, p.14).

${ }^{380}$ A ADPF 101, Tribunal Pleno, rel. Min. Cármen Lúcia, j. em 24.6.2009, DJe de 1.6.2012, teve origem em razão da discussão de decisões judiciais brasileiras que possibilitavam a importação de pneus usados de países que não fossem integrantes do Mercosul, em violação a acordos estabelecidos no âmbito desse mercado comum.
} 
Constituição Brasileira) e a busca de desenvolvimento econômico sustentável: princípios constitucionais da livre iniciativa e da liberdade de comércio interpretados e aplicados em harmonia com o do desenvolvimento social saudável”.

O STF reputou que a importação de pneus usados ou remoldados afronta os preceitos constitucionais de saúde e do meio ambiente ecologicamente equilibrado. Destacou-se que os pneus possuem uma durabilidade bastante elevada, o que "é responsável pela demora na sua decomposição quando descartado em aterros”, além da “dificuldade de seu armazenamento”. A disposição final dos pneus também foi indicada como problemática, porque a incineração “libera substâncias tóxicas e cancerígenas no ar” e a queima a céu aberto além de altamente poluente, pode provocar incêndios de difícil contenção. A aterragem dos pneus também é dificultada porque eles ocupam muito espaço e mesmo com a compactação eles "tendem a voltar à sua forma original e retornam à superfície”, em razão dos gases que são produzidos com a sua decomposição. Indicou-se ainda que "pneus inservíveis e descartados a céu aberto são criadouros de insetos e outros transmissores de doenças”. Em relação ao aspecto econômico indicou-se que a proibição da importação de pneus usados ou inservíveis não compromete a continuidade das atividades econômicas. Isso porque “o Brasil produz pneus usados em quantitativo suficiente para abastecer as fábricas de remoldagem de pneus, do que decorre não faltar matéria-prima a impedir a atividade econômica ${ }^{381, " . ~}$

Nesse sentido, a logística reversa deve verificar o dano ambiental, seja excesso de resíduos produzidos; degradação ambiental, poluição por contaminação do solo, dos mananciais ou até mesmo da população, relacionando-o ao bem ambiental a ser protegido $^{382}$. A imposição de deveres, obrigações e até mesmo sanções aos agentes econômicos, sejam produtores, fabricantes comerciantes ou importadores deve avaliar esse dano e as ações mais adequadas, tecnológica e economicamente, para solução do problema identificado.

\footnotetext{
381 Para um aprofundamento sobre a análise dessa decisão confira-se: LEMOS, Patrícia Faga Iglesias. Resíduos sólidos e responsabilidade civil pós-consumo: Lei da política nacional de resíduos sólidos (Lei 12.305/2010), Decreto regulamentador (Dec. 7.404/2010). Responsabilidade compartilhada, logística reversa, 2011, p. 230-239.

${ }^{382}$ A degradação pode ser compreendida como um processo de desgaste do solo, seja pela ação humana, que causa poluição, degradação química e esgotamento dos nutrientes, seja pela ação da natureza por meio da erosão, decorrente da ação dos ventos, da água e do sol ou da ação humana, com o desmatamento de matas ciliares, que provocam o assoreamento dos rios. Já a poluição é uma modalidade de contaminação que implicará na alteração das qualidades desse recurso. Sobre o tema consulte-se: SILVA, José Afonso da. Direito Ambiental Constitucional. 9. ed., 2011, p. 100.
} 


\subsection{Estímulos para o aumento da inserção dos resíduos na cadeia econômica}

O poder público pode orientar o desenvolvimento das atividades de logística reversa $^{383}$ por meio da aplicação de recursos públicos ${ }^{384}$, tendo em vista que os mecanismos meramente impositivos e repressivos não são suficientes para a implementação desse instrumento. A Lei 12.305/2010 e seu Decreto regulamentador preveem alguns instrumentos econômicos.

Há modalidades de incentivos creditícios, incentivos econômicos, incentivos fiscais, cessão de terrenos públicos, subvenções econômicas, previsão de critérios sustentáveis nas contratações públicas, pagamento por serviços ambientais e também incentivos específicos às associações e cooperativas de catadores de materiais recicláveis e reutilizáveis.

Esses instrumentos podem ser utilizados, conforme prevê o art. 42 da Lei 12.305/2010, para ações que visem prevenção e redução da geração de resíduos sólidos no processo produtivo (inc. I); desenvolvimento de produtos com menores impactos à saúde humana e à qualidade ambiental em seu ciclo de vida (inc. II); implantação de infraestrutura física e aquisição de equipamentos para cooperativas ou outras formas de associação de catadores de materiais reutilizáveis e recicláveis formadas por pessoas físicas de baixa renda (inc. III); desenvolvimento de projetos de gestão dos resíduos sólidos de caráter intermunicipal ou, nos termos do inciso I do caput do art. 11, regional; V estruturação de sistemas de coleta seletiva e de logística reversa (inc. IV); descontaminação de áreas contaminadas, incluindo as áreas órfãs (inc. VI); desenvolvimento de pesquisas voltadas para tecnologias limpas aplicáveis aos resíduos sólidos (inc. VII) e o desenvolvimento de sistemas de gestão ambiental e empresarial voltados para a melhoria dos processos produtivos e ao reaproveitamento dos resíduos (inc. VIII).

\footnotetext{
${ }^{383}$ NORBERTO BOBBIO alude à função promocional do direito, como forma de incentivar condutas desejadas. É um modo alternativo a função repressiva, visto que objetiva conferir vantagens ao agente que praticá-la. (Dalla struttura alla funzione: nuovi studi di teoria del diritto, 1977, p. 13-42). Na esteira do ensinamento desse autor, MARÇAL JUSTEN FILHO, menciona que: "É inviável eliminar o cunho repressivo do direito, mas é indispensável agregar instrumentos promocionais. Isso porque nenhum dos dois modelos isoladamente é apto a produzir resultados satisfatórios". (Curso de Direito Administrativo. 10. ed., 2010, p. 718).

${ }^{384}$ Essa orientação exercida pelo estado é decorrência da função administrativa de fomento. Sobre o tema confira-se: JUSTEN FILHO, Marçal. Curso de Direito Administrativo. 10. ed., 2010, p. 127 e 716-720.
} 


\title{
4.5 Criação de novos produtos: a "destruição criativa”
}

Como já mencionado, todos os aspectos socioeconômicos e ambientais interagem de múltiplas formas. Essas interações confere um caráter dinâmico às essas relações. Com base nisso JOSEPH A. SCHUMPETER desenvolveu a noção de “destruição criativa” como método para o capitalismo se adaptar às novas exigências. Ou seja, o autor reconhece que as modificações econômicas são dinâmicas, assim como a vida humana, afinal a esfera econômica não possui existência própria, mas depende do ser humano. Impondo-se dessa maneira transformações nos modos de produção, que envolvem uma nova concepção do produto, uma nova concepção de mercado, uma nova concepção de se fazer negócios. Nos dizeres desse autor:

\begin{abstract}
“(...) a vida econômica transcorre em um meio natural e social que se modifica e que, em virtude dessa mesma transformação, altera a situação econômica. Esse fato é importante e essas transformações (guerras, revoluções e assim por diante) produzem freqüentemente transformações industriais, embora não constituam seu móvel (...). $O$ impulso fundamental que põe e mantém em funcionamento a máquina capitalista procede dos novos bens de consumo, dos novos métodos de produção ou transporte, dos novos mercados e das novas formas de organização industrial criadas pela empresa capitalista $^{385,}$.
\end{abstract}

A criação de novos produtos, de novas embalagens, de novos métodos energéticos, de novos serviços, de novos meios de transporte, enfim novas formas de produção são mecanismos para a continuidade do sistema produtivo. Se não houver o desenvolvimento de novos métodos, muito possivelmente as empresas não conseguirão manter-se no mercado, pois a adaptação é um fenômeno inevitável.

Em décadas anteriores não havia uma preocupação com gestão dos resíduos sólidos, nem em relação ao ciclo de vida dos produtos, nem com a implementação de instrumentos de logística reversa. Em razão do padrão de produção desenvolvido, qual seja de desperdício de recursos, de curta durabilidade dos produtos, de utilização de espaços físicos de modo irregular para depósito de resíduos, sem qualquer tipo de tratamento prévio, gerou-se um quadro fático novo, diferente daquele inicial em que havia abundância de recursos e de espaços físicos. Há consequentemente escassez de recursos, toneladas de resíduos sem destinação correta, poluição dos solos, mananciais. Isso aliado à falta de espaços físicos, para necessidade até mais básicas como moradia ou até para a

${ }^{385}$ Capitalismo, Socialismo e Democracia. Trad. Ruy Jungmann, 1961, p. 110. 
produção agrícola ou pastoril, levam a uma nova conjuntura. Por tal razão, a adaptação se torna inevitável $^{386}$.

As novas estratégias devem ser, portanto, “demolidoras em relação à estrutura atual do segmento e levantam a possibilidade de reposicionamento significativo, permitindo que novos participantes estabeleçam posições de liderança ${ }^{387, "}$.

Transpondo essa ideia para o tema analisado, nota-se que inicialmente a logística reversa estava muito mais vinculada em obter soluções para obtenção de matérias-primas e solucionar a crescente escassez de recursos. Ou seja, apenas melhorar a situação do modo de produção existente. Mas com o tempo outras questões ambientais e sociais também foram ganhando a preocupação do setor econômico, o que exigiu não apenas o reuso e a valorização de resíduos, como, por meio da reciclagem, mas até mesmo novas formas de planejamento do processo produtivo, com desenvolvimento de novas tecnologias, novas concepções de durabilidade dos produtos, novos designs, além de envolver questões de prevenção da geração de resíduos.

A logística reversa a ser adotada envolve, portanto, uma análise da estrutura organizacional de cada empresa para se identificar quais serão "os pontos-chave para o processo de planejamento da logística reversa”, propondo-se potenciais alternativas ${ }^{388}$.

\subsubsection{Os investimentos em novas tecnologias}

A tecnologia deve ser utilizada para propiciar melhorias e maior compatibilização com o meio ambiente ${ }^{389}$. Os avanços tecnológicos permitem inclusive aumentar a abrangência de proteção ambiental. Assim destaca AMARTYA SEN:

"O entendimento de que alguns direitos não são plenamente realizados, e podem mesmo nem ser totalmente realizáveis nas circunstâncias atuais, não implica, por si só, a conclusão de que esses não seriam, portanto, direitos, essa compreensão ética sugere a necessidade de se trabalhar no sentido de alterar as

\footnotetext{
${ }^{386}$ HART, Stuart. L. O capitalismo na encruzilhada. As inúmeras oportunidades de negócios na solução dos problemas mais difíceis do mundo, 2006, p. 104.

${ }^{387}$ HART, Stuart. L. O capitalismo na encruzilhada. As inúmeras oportunidades de negócios na solução dos problemas mais difíceis do mundo, 2006, p. 104.

${ }^{388}$ BRACONI, Joana; COSTA, Marília Magarão. Formulação da Estratégia de Logística Reversa, 2014, p. 75.

${ }^{389}$ Há inclusive estudos que analisam estruturas da natureza para incorporar ao design e às funcionalidades dos produtos e dos processos de produção, o denominado design biológico - "biomimestismo”. Um exemplo são estudos que tentam reproduzir as fibras das aranhas para aumentar a durabilidade e torná-las insolúveis. (Capitalismo natural. Criando a próxima Revolução Industrial. 13. ed., 2010, p. 65-69).
} 
condições existentes para tornar realizáveis os direitos não

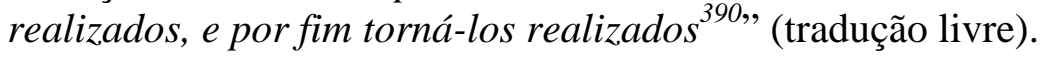

Mas paralelamente se mostra imprescindível a reinvenção de produtos e processos. ${ }^{391}$. A redução do consumo de matérias-primas e energia exige o investimento em novas tecnologias. Isso como forma de as empresas se adaptarem a novas demandas ${ }^{392}$.

Para PAUL HAWKEN, AMORY LOVINS, L. HUNTER LOVINS não há investimento mais lucrativo do que o desenvolvimento de novos designs ${ }^{393}$. A partir da reformulação dos produtos é possível se adaptar o sistema econômico a todo o meio que o rodeia. Os autores, com base num exemplo de J. BALDIW, mencionam que qualquer alteração dentro do ecossistema exige uma "coevolução", afinal as interações de todos os elementos, sejam socioeconômicos, ambientais ou culturais “espalham ramificações” em todo o sistema, que exigem um trabalhado conjunto de adaptação, com vistas a tornar as relações mais eficientes e equilibradas ${ }^{394}$. A redefinição do design, portanto, não é um mero aperfeiçoamento das coisas, mas uma ampliação de possibilidades ${ }^{395}$.

Um exemplo ilustrativo foi desenvolvido pela KX Industries, que desenvolveu um filtro de água para produzir de modo mais eficiente e econômico a purificação da água. O tratamento é tanto químico como biológico e independe do nível de contaminação. A produção desse filtro é bastante simples, exige baixos investimentos e permite melhorar as condições de saúde das populações mais carentes, reduzindo inclusive níveis de doenças, que se proliferam pela falta de tratamento da água. Essa empresa optou por desenvolver um produto diferenciado para um público também diferenciado - as camadas de menor renda econômica que até então estavam excluídas ao acesso de água potável. Com isso optou por explorar um novo nicho de mercado, a partir do desenvolvimento de uma nova tecnologia mais adequada do ponto de vista socioeconômico e ambiental ${ }^{396}$.

\footnotetext{
390 No original: "The understanding that some rights are not fully realized, and may not even be fully realizable under present circumstances, does not, in itself, entail anything like the conclusions that these are, therefore, not rights at all rather, this ethical understanding suggests... the need to work towards changing the prevailing circumstances to make the un realized rights realizable, and ultimately realized" (Elements of a Theory of Human Rights, Philosophy and Public Affairs, 2004, p. 348).

391 Já existem, por exemplo, produtos que são fabricados para substituir aqueles que não são renováveis, como o caso da fibra óptica, que substitui o fio de cobre. (HART, Stuart. L. O capitalismo na encruzilhada. As inúmeras oportunidades de negócios na solução dos problemas mais difíceis do mundo, 2006, p. 67). ${ }^{392}$ HART, Stuart. L. O capitalismo na encruzilhada. As inúmeras oportunidades de negócios na solução dos problemas mais difíceis do mundo, 2006, p. 67.

${ }^{393}$ Capitalismo natural. Criando a próxima Revolução Industrial. 13. ed., 2010, p. 104.

${ }^{394}$ Capitalismo natural. Criando a próxima Revolução Industrial. 13. ed., 2010, p. 105.

395 Capitalismo natural. Criando a próxima Revolução Industrial. 13. ed., 2010, p. 100.

${ }^{396}$ HART, Stuart. L. O capitalismo na encruzilhada. As inúmeras oportunidades de negócios na solução dos problemas mais difíceis do mundo, 2006, p. 74.
} 
Mas inovações tecnológicas também podem ser estendidas para uma infinidade de utensílios domésticos, como refrigeradores, que consumam menos energia, ou ainda máquinas de lavar que sejam mais eficientes na utilização de água ${ }^{397}$.

O estímulo ao desenvolvimento de novas tecnologias também pode ser incentivado com auxílio do Poder Público e da educação ambiental. Estima-se que o desenvolvimento de tecnologias permite que o consumo de energia seja menor hoje do que em décadas anteriores. Um exemplo de estímulo nesse sentido foi criado pela Agência de Proteção Ambiental Americana - EPA, em 1992, o programa, de adesão voluntária, chamado "Energy Star”. Esse programa é voltado a estimular a redução do consumo de energia, como forma de fomentar uma política de proteção climática e a redução do efeito estufa. Esse programa visa à certificação de produtos que consomem menos energia como forma de induzir produtos, práticas e serviços mais eficientes ${ }^{398}$.

No Brasil também foram criados, em 2005, pelo Inmetro, selos para certificar aos consumidores dos produtos dotados de maior eficiência energética, o selo Procel e o Conpet, este último exclusivo para equipamentos domésticos a gás ${ }^{399}$. Já a certificação da eficiência energética no âmbito industrial e comercial é feita pela ISO 50001.

Nesse sentido, pode-se citar ainda o Decreto 7.7.46/2012, que regulamenta o art. $3^{0}$ da Lei 8.666/1993, estabelecendo critérios para a promoção do desenvolvimento nacional sustentável nas contratações públicas federais. O art. $4^{\underline{0}}$ desse decreto prevê, por exemplo, a preferência aos materiais que decorram de inovações que reduzam a utilização de recursos naturais, que causem menor impacto ambiental, que tenham maior eficiência energética e também no consumo de água, dotados de maior durabilidade e menores custos de manutenção. Os critérios de sustentabilidade aplicam-se não apenas aos produtos, mas também aos modos de construção. Essa regulamentação é um estímulo, sem dúvidas, ao desenvolvimento de novas tecnologias.

\subsubsection{Os custos para implementação de novas tecnologias: o caso das externalidades}

Segundo informações divulgadas na abertura da $4^{\text {a }}$ Audiência Pública do Plano Nacional de Resíduos Sólidos da região Nordeste, o Brasil gasta cerca de R\$ 8 bilhões por ano em virtude de não promover o manejo adequado dos resíduos sólidos ${ }^{400}$. Portanto, o

\footnotetext{
${ }^{397}$ Capitalismo natural. Criando a próxima Revolução Industrial. 13. ed., 2010, p. 98.

${ }^{398}$ Para maiores informações, consulte-se: http://www.energystar.gov/about/. Acesso em 05.12.2014.

${ }^{399}$ Fonte: http://www.inmetro.gov.br/consumidor/pbeSelo.asp. Acesso em 05.12.2014.

400 Informações disponíveis no Portal de Meio Ambiente, confira-se: http://www.meioambiente.ufrn.br/?p=5970. Acesso em 15.10.2011.
} 
estudo de novas tecnologias que permitam a implementação da logística reversa se torna economicamente relevante.

COASE ensina: “Uma vez que os custos de realização de transações de mercado são tidos em conta, é claro que tal rearranjo de direitos só será realizado quando o aumento no valor da produção, em consequência da reorganização, for maior do que os

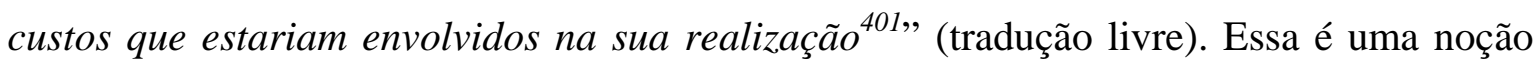
que se aplica aos investimentos em desenvolvimento sustentável e especificamente em relação à logística reversa. Isso porque embora os investimentos em tecnologia, de modo geral, exijam muitos recursos para o seu desenvolvimento, o custo das empresas reduz com a minimização do consumo de matéria-prima in natura, do consumo de energia. Além do que evita gastos futuros com eventual responsabilização pela resolução de problemas ambientais, como a disposição final adequada, descontaminação de áreas poluídas, dentre outros elementos. Como enfatizam GORDON TULLOCK, ARTHUR SELDON E GORDON L. BRADY: “... embora as regras gerem um custo, também resultam em benefício... ${ }^{402, "}$.

As exigências contemporâneas impõem o desenvolvimento de novos processos produtivos, que gerem um impacto ambiental mais reduzido. A logística reversa é um instrumento bastante importante para se atingir esse objetivo. A sua operacionalização adequada gera externalidades negativas, com gastos de desenvolvimento de novas tecnologias ou novas atividades, que passam a ser incorporadas na composição de custos, mas também gera externalidades positivas ${ }^{403}$, visto que permite reduzir os custos globais das empresas ${ }^{404}$.

A redução do fluxo de resíduos pode se dar mediante a alteração do design do produto, facilitando o reuso ou a desmontagem para a valorização do resíduo e ainda pelo

\footnotetext{
${ }^{401}$ Confira-se o trecho no idioma original: "Once the costs of carrying out market transactions are taken into account it is clear that such a rearrangement of rights will only be undertaken when the increase in the value of production consequent upon the rearrangement is greater than the costs which would be involved in bringing it about" (The problem of Social Cost. Journal of Law and Economics, v. 3, 1960, p. 13).

${ }^{402}$ TULLOCK, Gordon; SELDON, Arthur; GORDON, L. Brady. Falhas de governo: uma introdução à teoria da escolha pública, 2005, p. 26.

${ }^{403}$ Para PAULO ROBERTO LEITE um exemplo disso é que em alguns setores há dependência de matériasprimas secundárias, oriundas da logística reversa de pós-consumo, que representa em torno de 20 a $30 \%$ da matéria utilizada pela cadeia produtiva direta. (Logística reversa. Meio ambiente e competitividade. 2. ed., 2009, p. 9).

${ }^{404}$ Agora é claro que por vezes não haverá a correlação necessária entre o investimento e o resultado obtido, em alguns casos pode se investir muito e obter poucos avanços, mas essa situação inerente ao próprio processo de desenvolvimento. Ou seja, erros e acertos compõem essa equação. Mas de modo geral os investimentos trazem retornos financeiros e ambientais bastante significativos.
} 
aumento da longevidade. Mas a redução desse fluxo também pode se dar pela potencialização da utilização do bem, o que também pode reduzir custos.

Um exemplo da redução de custos referenciado por PAUL HAWKEN, AMORY LOVINS, L. HUNTER LOVINS é a criação de instalações compartilhadas para lavagens de roupas nos edifícios. A compra de diversas máquinas de lavar individuais exige um consumo energético muito maior do que a utilização de máquinas compartilhadas, que reduziriam inclusive a quantidade de materiais para a fabricação das máquinas. Outro exemplo ainda referenciado por esses autores é a criação de telhados verdes nos prédios, que aumentam a quantidade de superfícies porosas ajudando, nas grandes cidades, a absorção de água e o ciclo hidrológico. O desenvolvimento desses telhados se tornou um processo sofisticado e bastante competitivo, sobretudo na Alemanha. Segundo os autores relatam hoje é até difícil se conseguir alvará para construção de telhados que não sejam verdes, porque eles são muito eficientes na contenção de enchentes e na redução de custos com refrigeração ${ }^{405}$.

\subsection{Oportunidades de novos negócios empresariais: economia de serviços e serviços ecológicos}

A busca por diferentes formas de organização do processo produtivo e por maior sustentabilidade abriu espaço não apenas para novas tecnologias produtivas, mas também para novas concepções do sistema produtivo, que envolve também o conceito de utilização. Melhor explicando, há uma transferência do processo tecnológico focado na produção para um processo pautado na utilização, em que os fabricantes tornam-se, mais do que agentes especializados na produção, prestadores de serviços ${ }^{406}$.

Ao invés de se formular uma estratégia empresarial focada na produção e venda dos produtos, imaginem-se os serviços adquirindo relevância. Nessa lógica o consumidor passa a alugar os bens ao invés de comprá-los. Isso permite que os bens tenham maior durabilidade, exigindo apenas reparos ou aperfeiçoamentos ao longo do ciclo de vida. É com essa prestação de serviço que o produtor assume um novo papel na organização empresarial $^{407}$.

Um exemplo disso é um sistema criado na França para aquecimento dos prédios. Ao invés de se contratar a energia que irá aquecer os apartamentos, optou por contratar o

\footnotetext{
${ }^{405}$ Capitalismo natural. Criando a próxima Revolução Industrial. 13. ed., 2010, p. 100-101.

${ }^{406}$ STAHEL, Walter R. From Products to Services: Selling performance instead of goods, 2003.

${ }^{407}$ Capitalismo natural. Criando a próxima Revolução Industrial. 13. ed., 2010, p. 15.
} 
serviço dos “chauffagistes”, responsáveis por aquecê-los. São determinados um preço e o número de horas da prestação do serviço que são contratados pelos interessados. O contrato é de resultado e não de fornecimento. A taxa acaba sendo menor do que os métodos tradicionais de calefação. O mesmo tem ocorrido em empresas de ar condicionado nos Estados Unidos. Uma das maiores empresas do ramo possui um slogan, que traduz bem a relação ora estudada - "aluguel de conforto". O consumidor no final das contas quer o conforto, a utilidade e não o bem propriamente dito ${ }^{408}$.

Esse processo foi denominado por WALTER R. STAHEL de "economia de serviços”, o que nos dizeres do autor pode ser sintetizado como: “(...) uma economia que se centra na otimização da utilização (ou desempenho) de bens e serviços ${ }^{409,}$, sendo o objetivo econômico dessa economia possibilitar o maior tempo possível de utilização dos materiais. Essa economia de serviços é considerada "muito mais sustentável, ou desmaterializada do que a economia industrial, que é focada em produção como meio de criação de riqueza e na otimização do processo de produção, a fim de alcançar o

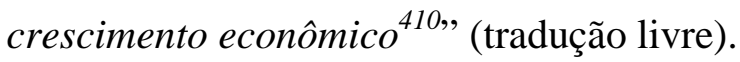

Outros autores se referem a essa mudança de paradigma de produção referindo-se não a economia de serviços, mas a serviços ecológicos - "eco-service" ${ }^{411}$. De qualquer modo, ambas as abordagens exigem não apenas novos designs, mas também novos padrões de consumo, novas estratégias de marketing para se permitir a redução do antagonismo entre certos produtos e os aspectos ambientais. A noção de serviços ecológicos não envolve o consumo dos produtos para si próprio, mas formas de utilização do bem ${ }^{412}$.

Isso exige evidentemente uma nova organização estratégica das empresas, pois o sucesso econômico e os lucros dependerão do desempenho e não da produção propriamente dita. A busca pela redução dos encargos financeiros dos produtos é essencial, para que se possam transferir os ganhos para a fase dos serviços de manutenção. Essa opção pela “desmaterialização” permite não apenas um desenvolvimento sustentável, com a redução do consumo de recursos, mas também ganhos econômicos ${ }^{413}$. Pode-se

\footnotetext{
${ }^{408}$ Capitalismo natural. Criando a próxima Revolução Industrial. 13. ed., 2010, p. 126.

${ }^{409}$ From Products to Services: Selling performance instead of goods, 2003.

${ }^{410}$ From Products to Services: Selling performance instead of goods, 2003.

${ }^{411}$ Nesse sentido, confira-se: BEHRENDT, Siegfried; JASCH, Christine; KORTMAN, Jaap; HRAUDA, Gabriele; PFITZNER, Ralf; VELTE, Daniele. Eco-service development. Reinventing supply and demand in the European Union, 2003, p. 6.

${ }^{412}$ BEHRENDT, Siegfried; JASCH, Christine; KORTMAN, Jaap; HRAUDA, Gabriele; PFITZNER, Ralf; VELTE, Daniele. Eco-service development. Reinventing supply and demand in the European Union, 2003, p. 6.

${ }^{413}$ From Products to Services: Selling performance instead of goods, 2003.
} 
acrescentar como consequência desta concepção também o estímulo à prevenção da geração de resíduos.

Muitas empresas têm adotado com sucesso essa estratégia dos serviços ecológicos. Nesse sentido destaca os Elevadores Schindler, que passam a vender um transporte vertical e não mais apenas elevadores; a Xerox que ao invés de copiadoras vende serviços de reprodução sob medida; a Safety-Kleen e Dow Europe que vendem serviços de produtos químicos e não apenas os produtos ${ }^{414}$; a Mobil Oil vendo o monitoramento da qualidade do óleo do motor, em vez de óleos do motor; a GE Capital e ILFC arrendam aeronaves, a Interface Inc. aluga tapetes de nylon ${ }^{415}$.

Como destacam PAUL HAWKEN, AMORY LOVINS e L. HUNTER LOVINS é possível que: “Um dia, a indústria vai alugar os móveis e o equipamento de escritório, o equipamento de fabricação e até o prédio inteiro, do mesmo modo que pode terceirizar os seus serviços de manufatura, marketing, tomada de pedidos e entregas a fim de criar uma empresa virtual em forma de rede". Essa tendência, como completam os autores, tende a promover um “fluxo contínuo de serviços” 416.

Mas para que exista um fluxo verdadeiramente sustentável é necessário modificarse o padrão de compra e venda. Ou seja, o vendedor, na maioria das vezes, tenta direcionar a compra do produto mais caro e não necessariamente daquele que melhor irá atender as exigências e necessidades do consumidor. Com o serviço ecológico a busca deve ser pelo produto mais adequado, para que a locação persista por mais tempo. Esse é um incentivo para produção de bens com maior durabilidade. Aqui também é necessária a alteração da exigência de produtos sempre novos, que é uma característica cultural, o que afasta essa concepção da economia de serviços do leasing tradicional ${ }^{417}$, porque nesse caso os

\footnotetext{
${ }^{414}$ A Dow Chemical Company aluga solventes orgânicos, que são perigosos, em razão da toxicidade ou inflamabilidade, e auxilia os clientes na utilização e na aplicação. O solvente não é vendido para o cliente, mas a utilização. A responsabilidade pela gestão desse produto continua com a empresa. A Xerox também desenvolveu uma máquina copiadora totalmente reciclável, com a utilização de poucas peças. Essa máquina é projetada com altos índices de eficiência energética e ambiental, faz menos ruídos, produz menos calor, é menos poluente, pode ser fabricada sob medida e até a folha a ser utilizada é reciclada. (HAWKEN, Paul; LOVINS, Amory e LOVINS, L. Hunter. Capitalismo natural. Criando a próxima Revolução Industrial. 13. ed., 2010, p. 128).

${ }^{415}$ From Products to Services: Selling performance instead of goods, 2003.

${ }^{416}$ Capitalismo natural. Criando a próxima Revolução Industrial. 13. ed., 2010, p. 132.

${ }^{417}$ Nesse sentido, confira-se a definição original: "Eco-leasing is fundamentally different from other leasing concepts where consumer goods are leased without ensuing ecological benefits and where no incentives are offered for the supplier to use products that have a long life-span and that are easy to repair and recycle (...). On the contrary, conventional leasing concepts can increase environmental impacts by stimulating consumption. Leasing concepts that do not have a purchase option seem to have more environmental advantages if the lessor pursues re-use and recycling” (BEHRENDT, Siegfried; JASCH, Christine;
} 
consumidores tendem, ao final do contrato ou até mesmo antes, a trocar o bem locado por outro mais novo $^{418}$.

Além da manutenção dos produtos, as empresas podem desenvolver sistemas de logística reversa, por meio de reuso, reciclagem, remanufatura dos resíduos que forem originados, considerando que, na maioria dos casos, os produtos continuam a ser propriedade da empresa. Isso facilita que exista a atribuição de deveres e responsabilidades pelo ciclo de vida do produto ${ }^{419}$ e também a redução do fluxo de resíduos.

Um elemento essencial para a economia de serviços é a reciclagem, mas deve se ter em vista que ela não é suficiente para reduzir o fluxo de resíduos. Por um lado, a reciclagem serve para fechar o ciclo dos produtos, para reduzir o volume de resíduos descartados e também colabora com a redução da utilização de recursos naturais. No entanto, a reciclagem não reduz o fluxo de matérias, mantém ou até aumenta, se se considerar a produção de matérias secundárias. A reciclagem por si só mantém uma estrutura econômica existente, suprindo a carência de matérias-primas, mas a alteração de um padrão produtivo mediante a valorização da prevenção exige ir além e buscar novos mecanismos como a economia de serviços ${ }^{420}$.

SIEGFRIED BEHRENDT, CHRISTINE JASCH, JAAP KORTMAN, GABRIELE HRAUDA, RALF PFITZNER e DANIELE VELTE elaboraram estudos de casos sobre os serviços ecológicos praticados em países europeus, como Alemanha, Holanda, Espanha e Áustria e apontam que há perspectiva de crescimento dessa modalidade, mas que ainda é preciso se melhorar no desenvolvimento desses serviços ${ }^{421}$. Eles identificam algumas deficiências: (i) em alguns casos os serviços ecológicos possuem preços mais elevados se comparados aos preços de compra, sendo preciso aumentar a competitividade; (ii) baixa utilização, salvo para carros e bicicletas; (iii) a regulação dos serviços ainda é insuficiente. De modo geral, os autores entendem que os serviços ecológicos existentes ainda não são a melhor forma de se atingir um consumo sustentável,

KORTMAN, Jaap; HRAUDA, Gabriele; PFITZNER, Ralf; VELTE, Daniele. Eco-service development. Reinventing supply and demand in the European Union, 2003, p. 19).

${ }^{418}$ Capitalismo natural. Criando a próxima Revolução Industrial. 13. ed., 2010, p. 127.

419 Nessa linha WALTER R. STAHEL destaca: “Em áreas onde os fabricantes não querem aceitar a responsabilidade alargada do produto, refabricantes independentes assumiram: óleo do motor rerrefinados como Safety-Kleen, reformadoras de pneus, empresas de desmantelamento de bens e revenda de peças em segunda mão, como a Phoenix Technologies nos Países Baixos, para citar apenas alguns. O número de empresas de um país envolvido nessas atividades é, normalmente, também um bom indicador do funcionamento da economia de mercado!”. (tradução livre). (From Products to Services: Selling performance instead of goods, 2003).

${ }^{420}$ STAHEL, Walter R. From Products to Services: Selling performance instead of goods, 2003.

${ }^{421}$ Eco-service development. Reinventing supply and demand in the European Union, 2003, p. 204. 
mas que representam uma forma de se obter melhorias e avanços em matéria ambiental, como a diminuição do número de bens produzidos e os incentivos a produção de bens mais duráveis. Indica-se ainda que os avanços desses serviços sejam dependentes da edição de uma boa regulação normativa.

\subsection{A dimensão social da logística reversa}

O aumento da proteção ambiental e a preocupação com a gestão de resíduos, em certa medida, também decorre da pressão social em face do poder público e dos empresários por mudanças. O cidadão hoje adquiriu uma consciência ambiental muito maior, exigindo produtos, operações e desempenhos mais sustentáveis.

Os cidadãos podem participar da formulação do modelo de logística reversa por meio da atuação de entidades representativas. Mas isso não exclui a proposição de sugestões e críticas em audiências e consultas públicas (art. 15, parágrafo único da Lei $12.305 / 2010)$.

Como já destacado pelo Tribunal de Contas da União a audiência pública é uma das formas mais seguras e eficientes de participação social. Nesse sentido confira-se o trecho do Acórdão 715/2004: “Não fica dispensada, entretanto, a determinação aos responsáveis para que não deixem de realizar audiências públicas quando a Lei exigir, por esta ser a forma mais segura e eficiente de se comprovar e assegurar a participação da sociedade na discussão dos assuntos relevantes que lhe afetam ${ }^{422, " . ~ P a r a ~ i s s o ~ e ́ ~}$ necessário que as audiências ou a consultas públicas não sejam um ato meramente formal de coleta de opiniões ${ }^{423}$. A Administração precisa levar em conta tudo que for proposto ${ }^{424}$.

As alterações legislativas acerca da gestão de resíduos sólidos visaram à participação social e das empresas interessadas. Houve a divulgação pela Administração da abertura de reuniões para discussões sobre a formulação de um Plano Nacional de Resíduos Sólidos ${ }^{425}$. Também foram prestadas diversas informações à sociedade e

\footnotetext{
422 Acórdão 715/2004, Plenário, rel. Min. Ubiratan Aguiar.

${ }^{423} \mathrm{O}$ art. 31, § $2^{0}$ da Lei 9.784/1999 dispõe que: “O comparecimento à consulta pública não confere, por si, a condição de interessado do processo, mas confere o direito de obter da Administração resposta fundamentada, que poderá ser comum a todas as alegações substancialmente iguais”. Esse dispositivo permite uma garantia ao interessado de que a sua proposição será efetivamente analisada pela Administração Pública.

${ }^{424}$ SOUTO, Marcos Juruena Villela. Audiência Pública e Regulação, 2003, p. 151-153.

${ }^{425}$ Até a conclusão do presente trabalho não havia sido publicada a versão final do Plano Nacional de Resíduos Sólidos. A última versão do plano foi divulgada em 2012 e está disponível no seguinte link: http://www.sinir.gov.br/documents/10180/12308/PNRS_Revisao_Decreto_280812.pdf/e183f0e7-5255-4544b9fd-15fc779a3657. Acesso em 12.12.2014.
} 
inclusive foi apresentado um modelo preliminar do plano de resíduos que se pretende implementar em âmbito nacional.

Houve contribuição da sociedade na formulação da PNRS por meio de audiências $^{426}$ e consultas públicas, em diversas regiões do país. Segundo dados divulgados pelo Ministério do Meio Ambiente, apenas na audiência nacional foram apresentadas cerca de novecentas sugestões diretas e quatrocentas sugestões pela Internet. Do total de proposições foram aceitas e incorporadas ao plano preliminar 168 emendas ${ }^{427-428}$.

Além disso, a participação dos consumidores na execução da logística reversa é fundamental, considerando-se que estão em contato direto com a maioria dos resíduos produzidos. Em alguns acordos setoriais (ou propostas desses acordos) se prevê a participação dos consumidores na logística reversa, mediante a entrega dos resíduos em pontos de coleta. Isso se aplica a diversos resíduos como de agrotóxicos, pneus, lâmpadas, óleos lubrificantes, pilhas e baterias, embalagens, medicamentos e eletroeletrônicos. O próprio art. 23, inc. VI do Decreto 7.404/2010 prevê, dentre os requisitos mínimos exigidos, que os planos contenham a forma de participação dos consumidores. Ainda existe a possibilidade de entidades representativas dos consumidores participarem na formulação dos acordos setoriais (art. 20, §3 do Decreto 7.404/2010).

A própria coleta seletiva depende da conscientização e da atuação ativa dos cidadãos, além do que a qualidade dos resíduos coletados depende da separação adequada.

Desse modo, o encargo pela execução da logística não fica adstrito à concepção do poluidor-pagador, que imputa apenas aos fabricantes a obrigação de bem gerir os resíduos. É evidente a obrigação dos fabricantes na mitigação dos danos ambientais provocados, afinal eles desenvolvem e gerenciam as atividades produtivas, mas compete

\footnotetext{
${ }^{426}$ Foram realizadas as audiências públicas nacionais em Brasília e cinco audiências públicas regionais no Centro-Oeste - Campo Grande/MS; no Sudeste - São Paulo; no Sul - Curitiba; no Nordeste - Recife e no Norte - Belém, além de consultas públicas pela Internet. No site do Ministério do Meio Ambiente foi disponibilizado um formulário, para que os interessados pudessem apresentar suas contribuições. Consulte-se o seguinte link:

http://www.cnrh.gov.br/projetos/pnrs/documentos/consulta/FORM_CONSULTA_PUBLICA_w_distributed. pdf.Acesso em 15.10.2011.

${ }_{427}$ Informações disponíveis em: http://www.ecodesenvolvimento.org/posts/2011/dezembro/mma-aprovanovas-propostas-para-o-plano-nacional. Acesso em 12.12.2014.

${ }^{428}$ Note-se que a audiência e a consulta públicas visam a possibilitar a participação dos interessados, mas isso não quer dizer que todas as manifestações sejam vinculantes, mas impõe o dever de justificativa do administrador pelo não acolhimento. Nesse sentido destacam SÉRGIO FERRAZ e ADILSON ABREU DALLARI: “(...) dos arts. 31 e 32 da Lei 9.784/1999 esclarece a não-obrigatoriedade de acatamento, pela Administração, das opiniões e alegações manifestadas na audiência pública. No entanto, à vista da pauta principiológica que baliza o processo administrativo, a decisão administrativa que desconsiderar ou rejeitar alegações produzidas na audiência pública deverá, sob pena de nulidade, não só ser expressa e fundamentada como, também, com atenção aos ditames da razoabilidade e da proporcionalidade, motivar cabalmente a rejeição do referido material” (Processo Administrativo. 2. ed., 2007, p. 182).
} 
também ao cidadão, que gere ou utilize um resíduo, assumir um papel ativo na logística reversa, até porque é ele quem procede ao descarte do resíduo. Ademais, o art. 225 da CF/88 dispõe que não é papel isolado do Estado cuidar do meio ambiente.

\subsubsection{Educação ambiental}

A participação social é relevante, mas para que isso seja possível é preciso que existam processos educativos, que aumentem o conhecimento da sociedade sobre a gestão de resíduos.

O Tratado de Educação Ambiental para Sociedades Sustentáveis e Responsabilidade Global, firmado no Rio de Janeiro, em 1992, prevê diversas diretrizes em matéria de educação ambiental, dentre elas que a: "educação ambiental deve ajudar a desenvolver uma consciência ética sobre todas as formas de vida com as quais compartilhamos este planeta, respeitar seus ciclos vitais e impor limites à exploração dessas formas de vida pelos seres humanos”. Como um dos planos de ação para executar a executar a educação ambiental prevê-se a investigação das: “causas dos hábitos consumistas” e busca pela "transformação dos sistemas que os sustentam”.

É dever de o Estado fomentar o debate e propor ações de educação ambiental, seja direta ou indiretamente, repassando recursos econômicos, como subsídios, financiamentos ou benefícios fiscais para projetos de educação ambiental ${ }^{429}$. Mas também compete aos fabricantes disponibilizarem informações corretas sobre o uso dos produtos, formas de descarte, sobre a possibilidade ou não de reuso.

A educação ambiental também pode auxiliar na tomada de decisão da compra dos produtos, pois irá possibilitar ao consumidor identificar melhor as funcionalidades, verificar a melhor relação entre o custo e os benefícios, assim como compreender os critérios de sustentabilidade que devem ser exigidos ${ }^{430}$. A informação sobre os produtos é relevante também, principalmente em relação àqueles que se tornem resíduos perigosos e possam oferecer risco de contaminação, como o caso de lâmpadas, medicamentos, óleos lubrificantes, agrotóxicos etc.

\footnotetext{
${ }^{429}$ Nesse sentido o Tratado de Educação Ambiental para Sociedades Sustentáveis e Responsabilidade Global prevê que os signatários devem: "Propor políticas econômicas que estimulem empresas a desenvolverem $e$ aplicarem tecnologias apropriadas e a criarem programas de educação ambiental para o treinamento de pessoal e para a comunidade em geral".

${ }^{430}$ XAVIER, Lúcia Helena; CORRÊA, Henrique Luiz. Sistemas de Logística Reversa. Criando Cadeias de Suprimento Sustentáveis, 2014, p. 126.
} 
Em muitos casos, a falta de interesse e participação na gestão de resíduos decorre da ausência de informação sobre os programas ambientais, como de coleta seletiva dos resíduos, de reciclagem, de compostagem ${ }^{431}$.

\subsection{Razoabilidade da solução de coordenação de interesses}

A efetivação das políticas públicas para a gestão dos resíduos sólidos envolve a colaboração tanto dos entes públicos como privados. Para isso deverá haver a participação tanto do Poder Público, como de empresários e da própria sociedade nos processos de tomada de decisões. Os mecanismos de participação devem possibilitar a "intervenção direta e efetiva nos processos de formulação de políticas públicas, alocação de recursos, edição de normas ${ }^{432 "}$ por parte dos interessados.

É nesse sentido que se abre espaço para a aplicação de métodos consensuais, por meio dos quais as partes tenham a possibilidade de dialogar e compor os conflitos decorrentes de interesses divergentes, de maneira a chegar a uma solução mais adequada ao caso concreto. Assim leciona DIOGO FIGUEIREDO MOREIRA NETO:

“É inegável que a renovada preocupação com o consenso, como forma de alternativa e ação estatal, representa para a Política e para o Direito uma benéfica renovação, pois contribui para aprimorar a governabilidade (eficiência), propicia mais freios contra os abusos (legalidade), garante a atenção de todos os interesses (justiça), proporciona decisão mais sábia e prudente (legitimidade), evita os abusos morais (licitude), desenvolve a responsabilidade das pessoas (civismo) e torna os comandos estatais mais aceitáveis e facilmente obedecidos (ordem) ${ }^{433}$,"

É dever de a Administração Pública buscar os melhores meios para a satisfação dos anseios sociais e isso pressupõe a participação de todos os interessados, principalmente porque é muito comum que exista sempre uma diversidade de interesses em causa. Isso exige ações coordenadas para que possa chegar a uma solução mais adequada. A atuação coordenada não prejudica os resultados a serem obtidos e nem se configura como mitigação do poder do Estado.

\footnotetext{
${ }^{431}$ BRINGHENTI, Jacqueline; GÜNTHER, Wanda M. Risso. Participação social em programas de coleta seletiva de resíduos sólidos urbanos, 2011, p. 429. Disponível em: http://www.scielo.br/pdf/esa/v16n4/a14v16n4.pdf. Acesso em 10.12.2014.

${ }^{432}$ MARQUES NETO, Floriano de Azevedo. Regulação estatal e interesses públicos, p. 186.

${ }^{433}$ MOREIRA NETO, Diogo Figueiredo. Novas Tendências da Democracia: Consenso e Direito Público na Virada do Século - o caso brasileiro, 2003, p. 36.
} 
Em última análise se os particulares tentarem impor seus interesses egoísticos caberá a Administração rejeitar as proposições indicadas sob esse fundamento. A participação dos cidadãos e dos empresários não pode ser vista como enfraquecimento da atuação do Estado, mas, pelo contrário, um fortalecimento, porque essa interação permite que as decisões tomadas estejam mais próximas das necessidades concretas. Além de permitir ao Estado conhecer mais profundamente a realidade que pretenda regular, normatizar ou ainda em que pretenda atuar.

Além disso, a cooperação entre os setores público e privado permite mitigar os problemas de incapacidade econômica e, em partes técnica, de executar ações necessárias para a gestão de resíduos, como a logística reversa. Permitindo-se inclusive o intercâmbio de experiências, seja com a gestão dos resíduos, propriamente ditos, seja com a coleta, armazenamento, transporte, com o desenvolvimento de tecnologias ou novos projetos de infraestrutura $^{434}$.

A atuação coordenada é um processo complexo, que envolve muitas dificuldades práticas como delimitar critérios objetivos para compor interesses distintos; a possibilidade de captura do poder público; em alguns casos, pode haver uma maior morosidade das decisões, afinal impor uma decisão unilateralmente pode ser um processo muito mais rápido do que analisar diversas proposições, críticas e sugestões ${ }^{435}$. No entanto, reputa-se que ainda assim essa solução é a mais razoável, porque privilegia a participação e maior transparência da Administração Pública.

\footnotetext{
${ }^{434}$ GARCÍA, José Francisco Alenza. El sistema de la gestión de resíduos sólidos urbanos en el derecho español, p. 348.

${ }^{435}$ Esse argumento deve ser relativizado, porque, por outro lado, a atuação coordenada pode impor uma atuação mais dinâmica da Administração, visto que a sociedade terá mais espaço para efetivar o controle de suas ações e exigir tempestivamente a realização das soluções que forem necessárias.
} 


\section{CONCLUSÃO}

Ao longo da presente dissertação procurou demonstrar-se que o descarte não controlado de resíduos, assim como o seu aumento vertiginoso passam a ser um ônus excessivo para a sociedade e para o poder público, seja em relação à questão ambiental ou de saúde pública, e até mesmo para própria atividade econômica, visto que os recursos naturais e os espaços para disposição dos rejeitos são finitos e tornam-se cada vez mais limitados. Como forma de mitigar essa situação indicou-se a necessidade da adoção de novos instrumentos, como a logística reversa, que permitam uma análise completa do ciclo de vida dos produtos, proporcionando o reaproveitamento e a redução da geração de resíduos.

Além disso, propôs-se a reflexão sobre novos métodos e concepções de desenvolvimento econômico. Para tanto, indicou-se a teorização da “destruição criativa $^{436, ", ~ a l e ́ m ~ d a ~ p o s s i b i l i d a d e ~ d e ~ s e ~ t r a n s f e r i r ~ a ~ c e n t r a l i d a d e ~ d o ~ m o d e l o ~ e c o n o ̂ m i c o ~ d e ~}$ vendas para a prestação de serviços, abrindo-se espaços os denominados "serviços ecológicos”. Esses serviços envolvem contratação da prestação de serviços em detrimento da compra do produto em si (ou seja, a reutilização dos produtos). Isso envolve o estímulo ao compartilhamento do uso dos produtos, por meio de algumas modalidades já conhecidas, como a locação e o leasing. Mas para que sejam considerados serviços ecológicos de fato, estimulando a redução ao invés do aumento do consumo; o aumento do cuidado na manipulação dos produtos, para que se conservem por mais tempo. Além disso, os agentes econômicos devem sentir-se estimulados a adotarem novos produtos, que sejam mais duráveis com vistas a permitir o maior tempo possível de reutilização, pois isso aumenta a lucratividade por parte dos agentes econômicos e a proteção aos recursos naturais.

Assume-se como inevitável que o uso de recursos naturais cause certa degradação do meio ambiente, afinal a própria existência humana por si só já provoca impactos ao meio ambiente. Reconhece-se uma margem de danos que são absorvíveis pelo ecossistema. No entanto, parcela das ações humanas excedem os limites que a natureza é capaz de suportar, o que compromete a existência de diversas espécies, da flora, a qualidade do ar e da água, que são alguns dos elementos vitais à sobrevivência humana.

Desse modo, procurou-se demonstrar que o desenvolvimento socioeconômico e a manutenção da qualidade de vida necessitam ser compatíveis com a utilização dos recursos

${ }^{436}$ SCHUMPETER, Joseph A. Capitalismo, Socialismo e Democracia. Trad. Ruy Jungmann, 1961, p. 110. 
naturais existentes e com a capacidade de renovação do meio ambiente. Isso como forma de garantir o direito fundamental à proteção do meio ambiente e o direito ao desenvolvimento socioeconômico sustentável.

A logística reversa é um instrumento que exige essa compatibilização de interesses econômicos, sociais e ambientais. Afinal exige uma atuação do setor empresarial no sentido de valorização de resíduos e no tocante à formulação de novos métodos produtivos, não apenas no sentido de se reinventar para continuar a existir, mas também como uma exigência de compatibilizar de seus métodos com a sustentabilidade ambiental. Os cidadãos também precisam reformular seus comportamentos de consumo e auxiliar na separação de resíduos para a coleta seletiva ou mediante a entrega em pontos de recolha. $\mathrm{O}$ poder público deve articular as ações a serem promovidas por agentes econômicos e a sociedade, por meio de normatizações, incentivos econômicos e da promoção da educação ambiental.

As políticas públicas relacionadas ao manejo de resíduos e rejeitos necessitam, portanto, da participação intensa tanto do Poder Público como de empresários e dos próprios cidadãos, de maneira a se chegar a melhor solução possível em cada caso concreto. Cada qual possuirá papel relevante na condução dessas políticas. A atuação consensual, coordenada e integrada em todas as atividades administrativas, sempre que possível, é imprescindível para a obtenção de bons resultados.

Como se tentou demonstrar o consenso tem por objetivo estabelecer uma relação de interação e comunicação entre as partes envolvidas ao longo do processo de tomada de decisões estatais ou de realização das atividades administrativas, permitindo um alcance mais efetivo e abrangente dos anseios a serem atingidos. Não apenas porque a decisão terá maior legitimidade e aplicabilidade, visto que o particular participou de sua construção, mas também porque permite a administração ter contato mais próximo com as peculiaridades concretas.

O consenso permite aproximar a autoridade administrativa da realidade concreta, de modo que possa obter um conhecimento mais específico, suprindo assim a eventual assimetria de informação entre seus conhecimentos e a realidade em que deve intervir e, sobretudo regular.

A atuação consensual, portanto, não implica a redução do poder estatal, mas a torna mais próxima de uma atuação instrumental, afastando-se uma atuação que considere o Estado como um fim em si mesmo. 
A participação da sociedade não pode ser vista como uma mitigação do interesse coletivo, mas como uma otimização da sua satisfação, porque os interesses coletivos (ou públicos como costuma de denominar) são pertencentes à sociedade e não ao Estado, a qual se imputa apenas a função de coordenação e efetivação desses interesses. 


\section{REFERÊNCIAS BIBLIOGRÁFICAS}

ABRELPE. Panorama dos Resíduos Sólidos no Brasil, 2012. Dados disponíveis em: http://www.abrelpe.org.br/Panorama/panorama2012.pdf. Acesso em 15.12.2014.

RENATO ALESSI. Principi di diritto amministrativo. 4. ed., Milano: Giuffrè, 1978.

ALFONSO, Luciano Parejo. Los actos Administrativos Consensuales en el Derecho Español, Revista de Direito Administrativo e Constitucional, n. 13, p. 11-43, jul./set.2003.

ALMEIDA, Fernando Menezes de. Mecanismo de consenso no Direito Administrativo. In: ARAGÃO, Alexandre Santos de; MARQUES NETO, Floriano de Azevedo (Coords.). Direito Administrativo e seus novos paradigmas, 2008. p. 335-349.

ALTHUSSER, Louis. Ideologia e aparelhos ideológicos do Estado. 3. ed., 1980.

AMARAL, Antonio Carlos Cintra do. O princípio da publicidade no direito administrativo, Revista Brasileira de Direito Público - RBDP, n. 2, p. 9-16, jul./set. 2003.

ANDRESEN, Steinar; BOASSON, Elin Lerum; HONNELAND, Geir. International environmental agreements: an introduction, London and New York: Routledge, 2011.

ARAGÃO, Alexandre Santos de. Direito Administrativo. 2. ed., Rio de Janeiro: Forense, 2013.

O princípio da proporcionalidade no Direito Econômico, Revista de Direito Administrativo - RDA, n. 223, p. 212-215, jan./mar. 2001.

ARAGÃO, Maria Alexandra de Souza. Direito Administrativo dos Resíduos. In: OTERO, Paulo; GONÇALVES, Pedro. Tratado de Direito Administrativo Especial, Coimbra: Almedina, 2009. p. 11-158. I. v.

O Direito dos Resíduos. Cadernos do CEDOUA. Coimbra: Almedina, 2003. 
O princípio do poluidor pagador como princípio nuclear da responsabilidade ambiental no direito europeu. In: GOMES, Carla Amado; ANTUNES, Tiago (Coords.). Actas do Colóquio. A responsabilidade civil por dano ambiental. Faculdade de Direito de Lisboa: Instituto de Ciências Jurídico-Política; Associação Portuguesa para o Direito do Ambiente; Instituto Lusíada para o Direito do Ambiente, 2009. p. 91-120. Disponível em: http://www.icjp.pt/publicacoes/1/737. Acesso em 15.09.2014.

. Os resíduos e a sua gestão internacional. In: O Direito e a Cooperação Ibérica, II Ciclo de conferências, Iberografias 7. Campo das Letras, 2006. p. 271-311.

ARAÚJO, Suely Mara Vaz Guimarães de; JURAS, Ilidia da Ascenção Garrido Martins. Comentários à Lei de Resíduos Sólidos. Lei no 12.305, de 2 de agosto de 2010 (e seu regulamento). São Paulo: Editora Pillares, 2011.

ARINAS, René Javier Santamaría. El régimen jurídico de los vertederos de residuos. Estudio jurisprudencial. Madrid: Cuadernos Cívitas, 1998.

ÁVILA, Humberto Bergmann. Repensando o "Princípio da Supremacia do Interesse Público sobre o Particular”, Revista Trimestral de Direito Público. São Paulo: Malheiros n. 24, p.159-179, 1998.

BAHIA, Carolina Medeiros. A responsabilização civil ambiental: seus dilemas em face da sociedade de risco e a problemática da prescrição da pretensão reparatória. In: FARIAS, Talden; COUTINHO, Francisco Seráphico da Nóbrega (Coords.). Direito Ambiental. O meio ambiente e os desafios da contemporaneidade. Belo Horizonte: Fórum, 2010.

BARROS, Regina Mambeli. Tratado sobre resíduos sólidos. Gestão, uso e sustentabilidade. Intercedência: Rio de Janeiro, 2013.

BARTHOLOMEU, Daniela Bacchi; BRANCO, José Eduardo Holler; CAIXETA-FILHO, José Vicente. A logística de transporte dos resíduos sólidos domiciliares (RSD). In: 
BARTHOLOMEU, Daniela Bacchi; CAIXETA-FILHO, José Vicente (Orgs.). Logística ambiental de resíduos sólidos. São Paulo: Atlas, 2011. p. 16-43.

Caracterização da Logística Reversa de Resíduos de Serviços de Saúde (RSS). In: BARTHOLOMEU, Daniela Bacchi; CAIXETA-FILHO, José Vicente (Orgs.). Logística ambiental de resíduos sólidos. São Paulo: Atlas, 2011. p. 44-66.

BEHRENDT, Siegfried; JASCH, Christine; KORTMAN, Jaap; HRAUDA, Gabriele; PFITZNER, Ralf; VELTE, Daniele. Eco-service development. Reinventing supply and demand in the European Union. Siegfried: Greenleaf Publishing, 2003.

BOBBIO, Norberto. Dalla struttura alla funzione: nuovi studi di teoria del diritto. Milano: Edizioni di Comunità, 1977.

BORTOLETO, Ana Paula. A Prevenção e a Análise do Ciclo de Vida na Gestão de Resíduos e Equipamentos Eletrônicos. In: XAVIER, Lúcia Helena; CARVALHO, Tereza Cristina Melo de Brito. Gestão de Resíduos Eletroeletrônicos: uma abordagem prática para a sustentabilidade. Rio de Janeiro: Elsevier, 2014. p. 19-33.

BLUMBERG, Donald F. Introduction to management of reverse logistics and closed loop supply chain processes. CPC Press: Washington, D.C. Taylor \& Francis e-Library, 2005.

BRACONI, Joana; COSTA, Marília Magarão. Formulação da Estratégia de Logística Reversa, In: VALLE, Rogerio; SOUZA, Ricardo Gabbay de (Orgs.). Logística reversa. Processo a processo. São Paulo: Atlas, 2014. p. 65-83.

BRANCO, José Eduardo Holler; BARTHOLOMEU, Daniela Bacchi; PINHEIRO, Maria Andrade; CAIXETA-FILHO, José Vicente. Caracterização da logística reversa de pneus inservíveis. In: BARTHOLOMEU, Daniela Bacchi; CAIXETA-FILHO, José Vicente (Orgs.). Logística ambiental de resíduos sólidos. São Paulo: Atlas, 2011. p. 67-84. 
CABRÉ, Alexandre Peñalver. La regulación municipal de los resíduos. Barcelona: Cedecs, 1997.

CAIXETA-FILHO, José Vicente; BARTHOLOMEU, Daniela Bacchi. Modelagem da Roteirização da Coleta de Resíduos Sólidos Urbanos. In: BARTHOLOMEU, Daniela Bacchi; CAIXETA-FILHO, José Vicente (Orgs.). Logística ambiental de resíduos sólidos. São Paulo: Atlas, 2011. p. 209-230.

CANOTILHO, José Joaquim Gomes; LEITE, José Rubens M. Direito Constitucional Ambiental Brasileiro. 3. ed., São Paulo: Saraiva, 2010.

CARVALHO FILHO, José Dos Santos. Manual de Direito Administrativo. 27. ed., São Paulo: Atlas, 2014.

CASSAGNE, Juan Carlos. Derecho Administrativo. 5. ed., Buenos Aires: AbeledoPerrot, 1996. I v.

CASSESE, Sabino. L'arena pubblica: nuovi paradigma per lo Stato. Rivista Trimestrale di Diritto Pubblico, n. 3, p. 601-650, 2001.

Quattro paradossi sui rapporti tra poteri pubblici ed autonomie private. Rivista Trimestrale di Diritto Pubblico, v. 2, p. 389-394, 2000.

CÉSPEDES, Carlos Bolaños. Desarrollo sostenible: un nuevo paradigma para la humanidad, Revista Parlamentaria de la Asamblea Legislativa de Madrid. v. 10, n.2, ago., p. 287-299, 2002.

CHEVAllier, Jacques. A Governança e o Direito, Revista de Direito Público da Economia - RDPE, v. 12, p. 129-167, out./dez. 2005.

COASE, Ronald H. The problem of Social Cost, Journal of Law and Economics, Oct. 1960. 3. v. 
CORRÊA, Ceres Fernanda; GOMES, Eduardo Biacchi, O direito fundamental ao desenvolvimento sustentável: uma análise a partir do caso das papeleras, Revista de Informação Legislativa, ano 48, n. 189, p. 177-187, jan.-mar., 2011.

COSTA, Lourenço; MENDONÇA, Fabrício Molica de; SOUZA, Ricardo Gabbay de. O que é Logística reversa. In: VALLE, Rogerio; SOUZA, Ricardo Gabbay de (Orgs.). Logística reversa. Processo a processo, São Paulo: Atlas, 2014. p. 18-33.

CIPRIANO, Tasso A. Richetti Pires. A juridificação dos resíduos no Brasil. In: PHILLIP JR., Arlindo; PASSOS DE FREITAS, Vladimir; SPÍNOLA, Ana Luiza Silva. Direito Ambiental \& sustentabilidade, no prelo.

O conceito econômico-jurídico de desenvolvimento sustentável. In: Cadernos O Direito - Temas de Direito do Ambiente. v. 6, Coimbra: Almedina, 2011. p. 360-377.

D’ANDREA, Giovannella; PACINI, Nic. New Decree Clarifies Law on Secondary Raw Materials and By-products, International Law Office. fev. 2009.

DALLARI, Adilson Abreu. Anulação do contrato administrativo. In: BICALHO, Alécia Paolucci Nogueira; DIAS, Maria Tereza Fonseca [Coord.]. Contratações Públicas. Estudos em homenagem ao Professor Carlos Pinto Coelho Motta. Belo Horizonte: Fórum, 2013. p. 23-31.

DE BRITO, Marisa P. Managing reverse logistics or reversing logistics management? Thesis to obtain the degree of Doctor from the Erasmus University Rotterdam, 2003. Disponível em: http://repub.eur.nl/pub/1132/. Acesso em 11.11.2014.

DEKKER, Rommert; DE BRITO, Marisa P. A Framework for reverse logistics. ERIM Report series Research in Management. Rotterdam: Erasmus Research Institute of Management, 2003.

DERANI, Cristiane. Direito Ambiental Econômico. São Paulo: Max Limonad, 1997. 
DE VICENTIIS, Giuseppantonio. La evolución del concepto de desarrollo sostenible, Medio Ambiente \& Derecho: Revista electrónica de derecho ambiental, n. 23, jul. 2012. Disponível em: http://huespedes.cica.es/gimadus/. Acesso em 20.11.2012.

DI PIETRO, Maria Sylvia Zanella. Participação popular na Administração Pública, Revista de Direito Administrativo, n. 191, p. 26-39, jan./mar., 1993.

DI PIETRO, Maria Sylvia Zanella; MARTINS JUNIOR, Wallace Paiva (Coord.). Teoria Geral e princípios do Direito Administrativo. São Paulo: RT, 2014.

DROMI, Roberto. Derecho Administrativo. 6. ed., Buenos Aires: Ciudad Argentina, 1997.

EUROPEAN COMMISSION. Being wise with waste: the EU's approach to waste management. Luxembourg: European Commission, 2010.

FARIA, José Eduardo. O Direito na Economia Globalizada, São Paulo: Malheiros, 2000.

FERRAZ, Sérgio, DALlARI, Adilson. Processo Administrativo. 2. ed., São Paulo: Malheiros, 2007.

FÉRNANDEZ RAMOS, Severiano, La política comunitária sobre resíduos: aspectos jurídicos generales, Revista de Derecho Ambiental, n. 11, p. 71-138, 1993.

FLEISCHMANN, Moritz. Quantitative model for reverse Logistics. Thesis to obtain the degree of Doctor from the Erasmus University Rotterdam, 2000.

FREITAS, Juarez. Direito fundamental à boa administração pública e o reexame dos institutos da autorização de serviço público, da convalidação e do 'poder de polícia administrativa’. In: ARAGÃO, Alexandre Santos de; MARQUES NETO, Floriano de Azevedo (Coords.). Direito Administrativo e seus novos paradigmas. Belo Horizonte: Fórum, 2012. 
Sustentabilidade. Direito ao Futuro. 2. ed., Belo Horizonte: Fórum, 2012.

FREITAS, Vladimir Passos de; FREITAS, Mariana Almeida Passos de. Direito Administrativo e Meio Ambiente. 5. ed., Curitiba: Juruá, 2014.

GARCÍA, José Francisco Alenza. El sistema de la gestión de resíduos sólidos urbanos en el derecho español. Madrid: Ministerio de Administraciones Públicas, 1997.

GARCÍA-ALCALÁ, Calixto Díaz-Regañón. El régimen jurídico-privado de los resíduos. Madrid: Editorial Montecorvo, 1998.

GEBERS, Betty; JÜLICH, Ralf; BIZER, Kilian; INGRAM, Verena; BIEKART, Jan Willem; MISSONNE, Delphine; KHALASTCHI, Ruth. Environmental Agreements. The role and effect of Environmental Agreements in Environmental Policies. Cameron May, 1998.

GEORGESCU-ROEGEN, Nicholas. O Decrescimento. Entropia, Ecologia, Economia. Trad. Maria José Perillo Isaac. São Paulo: Editora Senac, 2012.

GIANNINI, Massimo Severo. Il potere discrezionale della pubblica amministrazione. Milano: Giuffrè, 1939.

GREVE, Curtis; DAVIS, Jerry. Executive's guide to reverse logistics: how to find hidden profits by managing returns. Ebook Kindle, 2012.

Reverse Logistics. Recovering Lost Profits by Improving. UPS, 2012.

GRIMBERG, Elisabeth. A Política Nacional de Resíduos Sólidos: a responsabilidade das empresas e a inclusão social. São Paulo: Instituto Pólis, 2004. Disponível em: http://polis.org.br/publicacoes/a-politica-nacional-de-residuos-solidos-a-responsabilidadedas-empresas-e-a-inclusao-social/. Acesso em 12.07.2014. 
GRINOVER, Ada Pellegrini; VASCONCELLOS, Antônio Herman de; FINK, Daniel Roberto; FILOMENO, José Geraldo Brito; WATANABE, Kazuo; NERY JUNIOR, Nelson; DENANI, Zelmo. Código Brasileiro de Defesa do Consumidor comentado pelos autores do anteprojeto. 8. ed., Rio de Janeiro: Forense Universitária, 2004.

GUARNIERI, Patrícia. Logística Reversa. Em busca do equilíbrio econômico e ambiental. Recife: Clube dos Autores, 2011.

GUERRA, Sidney. Resíduos Sólidos. Rio de Janeiro: Forense, 2012.

GUIDE, V. Daniel R.; WASSENHOVE, Luk N. Van. Closed-loop supply chains. In: KLOSE, Andreas; SPERANZA, M. Grazia; WASSENHOVE, Luk N. Van (Editors). Quantitative approaches to distribution logistics and supply chain management. Berlin: Springer, 2002.

GUILTINAN, Joseph; NWOKOYE, Nonyelu. Reverse channels for recycling: an analysis for alternatives and public policy implications. In: CURHAN, R. G. (Editor). New marketing for social and economic progress. Combined Proceedings. American Marketing Association, 1974.

HART, Stuart L. O capitalismo na encruzilhada. As inúmeras oportunidades de negócios na solução dos problemas mais difíceis do mundo. Trad. Luciana de Oliveira Rocha. Porto Alegre: Bookman, 2006.

HAWKEN, Paul; LOVINS, Amory; LOVINS, L. Hunter . Capitalismo natural. Criando a próxima Revolução Industrial. Trad. Luiz A. Araújo; Maria Luiza Felizardo. 13. ed., São Paulo: Cultrix, 2010.

IDEC. Lâmpadas fluorescentes: onde descartá-las? Revista do Idec, n. 166, jun. 2012. Disponível em: $\quad$ http://www.idec.org.br/em-acao/revista/livrosinacessiveis/materia/lampadas-fluorescentes-onde-descarta-las/pagina/184. Acesso em 29.12.2014. 
IPEA. Diagnóstico dos Resíduos Sólidos de Logística Reversa Obrigatória - Relatório de Pesquisa Ipea, Brasília: Ipea, 2012.

JUSTEN FILHO, Marçal. Curso de Direito Administrativo. 10. ed., São Paulo: RT, 2014.

Conceito de Interesse Público e a "Personalização" do Direito Administrativo, Revista Trimestral de Direito Público, n. 26, p. 118, 1999.

KIM, Byung-In; KIM, Seongbae; SAHOO, Suraya. Waste collection vehicle routing problem with time Windows, Journal Computers and Operations Research, v. 33, p. 3624-3642, 2006.

LAGARINHOS, Carlos Alberto Ferreira. Reciclagem de pneus: análise do impacto da legislação ambiental através da logística reversa - Tese de doutoramento em engenharia. São Paulo: Escola Politécnica da Universidade de São Paulo, 2011.

. ; TENORIO, Jorge Alberto S., Tecnologias utilizadas para a reutilização, reciclagem e valorização energética de pneus no Brasil. Polímeros: Ciência e Tecnologia, São Carlos, v. 18, n. 2, p. 106-118, jun. 2008. Disponível em: http://www.scielo.br/scielo.php?script=sci_arttext\&pid=S0104-14282008000200007. Acesso em 11.11.2014.

LATOUCHE, Serge. Pequeno tratado do decrescimento sereno, São Paulo: Martins Fontes, 2009.

LEITE, Paulo Roberto. Logística reversa. Meio ambiente e competitividade. 2. ed., São Paulo: Pearson Prentice Hall, 2009.

LEMOS, Patrícia Faga Iglesias. Resíduos sólidos e responsabilidade civil pósconsumo: Lei da política nacional de resíduos sólidos (Lei 12.305/2010), Decreto regulamentador (Dec. 7.,404/2010). Responsabilidade compartilhada, logística reversa, São Paulo: RT, 2011. 
; MENDES, João Múcio Amado, Resíduos eletroeletrônicos e seus aspectos jurídicos no Brasil. In: XAVIER, Lúcia Helena; CARVALHO, Tereza Cristina Melo de Brito. Gestão de Resíduos Eletroeletrônicos: uma abordagem prática para a sustentabilidade. Rio de Janeiro: Elsevier, 2014. p. 49-66.

LOPEZ, Teresa Ancona. Princípio da precaução e evolução da responsabilidade civil. São Paulo: Quartier Latin, 2010.

LOSEKANN, Cristiana, Participação da sociedade civil na política ambiental do Governo Lula. Ambiente \& Sociedade [online], v. 15, n. 1, jan./abr., p. 179-200, 2012. Disponível em: $\quad$ http://www.scielo.br/scielo.php?script=sci_arttext\&pid=S1414753X2012000100012\&lng=en\&nrm=iso. Acesso em 15.12.2014

MARQUES NETO, Floriano De Azevedo. A concessão como instituto do direito administrativo. 2013. 628 f. Tese (Professor Titular em Direito) - Faculdade de Direito, Universidade de São Paulo, São Paulo, 2010.

Bens públicos: função social e exploração econômica: o regime das utilidades públicas. Belo Horizonte: Fórum, 2009.

La moderna regulación: la búsqueda de un equilibrio entre lo público y lo privado. In: AMICORUM, Liber; ORTIZ, Gaspar Ariño. Derecho Administrativo y regulación económica. Argentina: La Ley, 2011.

. O fomento como instrumento de intervenção estatal na ordem econômica, Revista de Direito Público da Economia, n. 32, p. 57-71, out./dez. 2010.

Regulação estatal e interesses públicos. São Paulo: Malheiros, 2002.

MARTINS, Pedro A. Batista. Arbitrabilidade objetiva, Interesse Público, indisponibilidade de direitos e normas de ordem pública. In: LEITE, Eduardo de Oliveira. (Coord.). 
Mediação, arbitragem e conciliação. Grandes Temas da Atualidade, v. 7. Rio de Janeiro: Forense, 2008.

MATEO, Ramón Martín. Manual de Derecho Administrativo. 25. ed., Navarra: Editorial Aranzadi, 2006.

Nuevo ordenamiento de la basura. Madrid: Trivium, 1998.

MCDONOUGH, William; BRAUNGART, Michael. Cradle to Cradle: Remaking the Way We Make Things. North Point Press: New York, 2012.

MCKINNON, Alan et. al. Green Logistics: Improving the Environmental Sustainability of Logistics, $2^{\text {nd }}$ ed., Kogan Page, 2012.

MEADOWS, Donella H.; RANDERS, Jorgen; MEADOWS, Dennis L.; BEHRENS, William W. The limits to growth: A report for the Club of Rome`s Project on the Predicament of makind. Universe Books, 1972.

MEDAUAR, Odete. Direito Administrativo Moderno. 18. ed., São Paulo: RT, 2014.

MENDONÇA, Fabrício Molica de; PONTES, André Teixeira; SOUZA, Ricardo Gabbay de. Logística reversa, Meio Ambiente e Sociedade. In: VALLE, Rogerio; SOUZA, Ricardo Gabbay de (Orgs.). Logística reversa. Processo a processo. São Paulo: Atlas, 2014. p. 517.

MENEZES DE ALMEIDA, Fernando. Contrato administrativo. São Paulo: Quartier Latin, 2012.

MIGUEZ, Eduardo Correia. Logística reversa como solução para o problema do lixo eletrônico: benefícios ambientais e financeiros. Rio de Janeiro: Qualitymark, 2010.

MILARÉ, Édis. Direito do ambiente. A Gestão ambiental em foco. 8. ed., São Paulo: RT, 2013. 
MONCADA, Luis S. Cabral de. Direito Económico. 2. ed., Coimbra: Coimbra Editora, 1988.

MONTEIRO, Vera. Concessão. São Paulo: Malheiros, 2010.

MOREIRA, Danielle de Andrade. Responsabilidade ambiental pós-consumo: da prevenção à reparação de danos. Tese de Doutoramento defendida na Universidade do Estado do Rio de Janeiro, Rio de Janeiro: UERJ, 2008.

MOREIRA NETO, Diogo de Figueiredo. Curso de Direito Administrativo, 15. ed., Rio de Janeiro: Forense, 2009.

Direito Regulatório. Rio de Janeiro: Renovar, 2003.

Introdução ao Direito Ecológico e ao Direito Urbanístico. Rio de Janeiro: Forense, 1975.

. Novas Tendências da Democracia: Consenso e Direito Público na Virada do Século - o caso brasileiro, Revista Brasileira de Direito Público, n. 3, p. 35-53, out./dez., 2003.

O futuro das cláusulas exorbitantes nos contratos administrativos. In: Aragão, Alexandre Santos de; MARQUES NETOS, Floriano de Azevedo (Coords.). Direito Administrativo e seus novos paradigmas. Belo Horizonte: Fórum, 2008. p. 571-592.

Poder, Direito e Estado. O Direito Administrativo em tempos de globalização. In memorium de Marcos Juruena Villela Souto. Belo Horizonte: Fórum, 2011.

MOREIRA, Vital. Autorregulação profissional e administração pública. Coimbra: Almedina, 1997. 
NOBRE, Marcos. Desenvolvimento sustentável: a institucionalização de um conceito. Brasília: Ibama, 2002.

NOSCHANG, Patrícia Grazziotin, O Caso das Papeleras na Corte Internacional de Justiça - Direito Ambiental versus Direito Econômico? Revista de Direito da UNIGRANRIO, v. 1, n. 1, 2008. Disponível em: http://publicacoes.unigranrio.edu.br/index.php/rdugr/ article/viewFile/201/200. Acesso em 12.07.2011.

NOVAIS, Jorge Reis. Contributo para uma Teoria do Estado de Direito. Coimbra: Almedina, 2006.

NUSDEO, Ana Maria. O uso de instrumentos econômicos nas normas de proteção ambiental, Revista da Faculdade de Direito da Universidade de São Paulo, v. 101, p. 376, p. 357-378, jan.- dez., 2006.

Pagamento por serviços ambientais: sustentabilidade e disciplina jurídica.

São Paulo: Altas, 2012.

OLIVEIRA, Gustavo Justino; SCHWANKA, Cristiane. A Administração Consensual como a nova face da Administração Pública no Séc. XXI: Fundamentos dogmáticos, formas de expressão e instrumentos de ação, Revista da Faculdade de Direito da USP, v. 104, p. 303-322, 2009. Disponível em: http://www.revistas.usp.br/rfdusp/article/view/67859. Acesso em 29.11.2014.

OLIVEIRA, Regis Fernandes. Ato Administrativo. 5. ed., São Paulo: RT, 2007.

ORTEGA, Francisco Román. Diccionario de Medio Ambiente y materias afines. Madrid: Fundacion Confemental, 1999.

OTERO, Paulo. Legalidade e Administração Pública. O sentido da vinculação administrativa à juridicidade. Coimbra: Almedina, 2007. 
ORTIZ, Gaspar Ariño. Principios de Derecho Público Económico. Modelo de Estado, Gestión Pública, Regulación Económica. 3. ed., Buenos Aires: Editorial Comares, 2004.

PAIVA, Teresa; PROENÇA, Reinaldo. Marketing Verde. São Paulo: Almedina, 2011.

PALMA, Juliana Bonacorsi de. Atuação administrativa consensual. Estudo dos acordos substitutivos no processo administrativo sancionador. 2010. 332 f. Dissertação (Mestrado em Direito) - Faculdade de Direito, Universidade de São Paulo, São Paulo, 2010.

PEREIRA DA SILVA, Vasco Manuel Pascoal Dias. Em busca do acto administrativo perdido. Coimbra: Almedina, 1996.

PINHEIRO, Maria Andrade; BARTHOLOMEU, Daniela Bacchi; CAIXETA-FILHO, José Vicente. Logística de Resíduos Sólidos em Campinas. In: BARTHOLOMEU, Daniela Bacchi; CAIXETA-FILHO, José Vicente (Orgs.). Logística ambiental de resíduos sólidos, São Paulo: Atlas, 2011. p.171-189.

POCHAMPALLY, Kishore K.; NUKALA, Satish; GUPTA, Surendra M. Strategic planning models for reverse and closed-loop supply chains. Taylor and Francis CRC Press, USA, 2008.

PONTES DE MIRANDA, Francisco Cavalcanti. Comentários à Constituição de 1967 com a emenda no 1, de 1969, T. 3, 2. ed., São Paulo: RT, 1973.

RIVERO, Jean. Direito Administrativo. Trad. Rogério Ehrhardt Soares. Coimbra: Almedina, 1981.

ROGERS, Dale; TIBBEN-LEMBKE, Ron. Going Backwards: Reverse Logistics Trends and Practices, Pittsburgh: Reverse Logistics Executive Council, 1999.

ROQUE, Ana. Regulação do Mercado. Novas tendências. Lisboa: Quid Juris, 2004. 
SANTOS, António Carlos dos; GONÇALVES, Maria Eduarda; MARQUES, Maria Manuel Leitão. Direito Económico. 4. ed., Coimbra: Almedina, 2001.

SÁNCHEZ SÁEZ, Antonio José. Otro paso a oscuras en la necesaria delimitación conceptual del abandono de residuos: la Sentencia 496/2.003, de 14 de mayo, de la Sala de lo Contencioso-Administrativo del Tribunal Superior de Justicia de Galicia, Medio Ambiente \& Derecho: Revista Electrónica de Derecho Ambiental, n. 11, dic., 2004. Disponível em: http://huespedes.cica.es/gimadus/11/abandono.htm. Acesso em 20.11.2014.

SANTOS, Juliana Vieira dos. A gestão dos resíduos sólidos urbanos: um desafio. São Paulo: Faculdade de Direito do Largo São Francisco da USP, 2009.

SCHATTEMAN, Olaf. Reverse logistics. In: GATTORNA, John (Coord.). Gower handbook of supply chain management. 5. ed., 2008.

SCHIER, Paulo Ricardo. Ensaio sobre a Supremacia do Interesse Público sobre o Privado e o Regime Jurídico dos Direitos Fundamentais, Revista Brasileira de Direito Público, n. 4, p. 167-185, jan./mar. 2004.

SCHUMPETER, Joseph A. Capitalismo, Socialismo e Democracia. Trad. Ruy Jungmann. Rio de Janeiro: Editora Fundo de Cultura, 1961.

SCOCA, Franco Gaetano. La discrezionalità nel pensiero di Giannini e nella dottrina successiva. Rivista trimestrale di diritto pubblico - Vita ed opere di Massimo Severo Gianinni, v. 4, p.1045-1072, 2000.

SEN, Amartya. Elements of a Theory of Human Rights, Philosophy and Public Affairs. Fall, 2004.

SILVA, José Afonso da. Direito Ambiental Constitucional. 9. ed., São Paulo: Malheiros, 2011. 
SOUTO, Marcos Juruena Villela. Audiência Pública e Regulação, Revista de Direito Público da Economia - RDPE, n. 4, p. 145-167, out./dez., 2003.

SOUZA, Herval Barros de; RIBEIRO, João Paulo Da Silveira. Aspectos regulatórios da geração de energia elétrica a partir de resíduos sólidos urbanos. In: FÁBIO AMORIN DA ROCHA. Temas relevantes no Direito da Energia Elétrica. Rio de Janeiro: Synergia, 2013. p. 400-418.

SOUZA, Marcelle Rodrigues de; SOUZA, Ricardo Gabbay de. Beneficiamento. In: VALLE, Rogerio; SOUZA, Ricardo Gabbay de (Orgs.). Logística reversa. Processo a processo. São Paulo: Atlas, 2014. p. 132-153.

Destinação final. In: VALLE, Rogerio; SOUZA, Ricardo Gabbay de (Orgs.).

Logística reversa. Processo a processo. São Paulo: Atlas, 2014. p. 154-159.

STAHEL, Walter R. From Products to Services: Selling performance instead of goods. Genève: Institut de la Durée, 2003.

STEIGLEDER, Annelise Monteiro. Responsabilidade Civil Ambiental. As dimensões do dano ambiental no direito brasileiro. 2. ed., Porto Alegre: Livraria do Advogado, 2011.

SUNDFELD, Carlos Ari. Direito Administrativo Ordenador. São Paulo: Malheiros, 1993.

Direito Administrativo para Céticos. São Paulo: Malheiros, 2012.

TERÁN, Antonio Burgués; MORA, Alvaro López, ¿Apertura por apertura o desarrollo sostenido? Revista Relaciones Internacionales, n. 55, 1996. p. 23-25.

TULLOCK, Gordon; SELDON, Arthur e GORDON, L. Brady. Falhas do governo: uma introdução à teoria da escolha pública. Rio de Janeiro: Instituto Liberal, 2005. 
UNITED STATES ENVIRONMENTAL PROTECTION AGENCY - EPA. Municipal Solid Waste Source Redution. A Snapshot of State Initiatives. Washington, 1998, p. 3. Disponível em: http://www.epa.gov/osw/nonhaz/municipal/pubs/snapshot.pdf. Acesso em 14.11.2014.

VALLE, ROGÉRIO; GABBAY, Ricardo Souza (Orgs.). Logística reversa. Processo a processo. São Paulo: Atlas, 2014.

VAZ, Letícia. Educação ambiental e logística reversa. Trabalho apresentado no II Congresso Brasileiro de Gestão Ambiental. Goiânia, 2012. Disponível em: http://www.ibeas.org.br/congresso/Trabalhos2012/VII-022.pdf. Acesso em 12.7.2014.

VEIGA, José Eli da. Sustentabilidade. A legitimação de um novo valor. São Paulo: SENAC, 2010.

XAVIER, Lúcia Helena; CARVALHO, Tereza Cristina Melo de Brito. Introdução à Gestão de Resíduos de Equipamentos Eletroeletrônicos. In: XAVIER, Lúcia Helena; CARVALHO, Tereza Cristina Melo de Brito. Gestão de Resíduos Eletroeletrônicos: uma abordagem prática para a sustentabilidade. Rio de Janeiro: Elsevier, 2014. p. 118.

XAVIER, Lúcia Helena; CORRÊA, Henrique Luiz. Sistemas de Logística Reversa. Criando Cadeias de Suprimento Sustentáveis. São Paulo: Atlas, 2013.

WIESMETH Hans; HÄCKL. Dannis. How to successfully implement extended producer responsibility: considerations from an economic point of view. Waste Management \& Research. ISWA/Sage, 2011. Disponível em: http://wmr.sagepub.com/content/29/9/891. Acesso em 03.12.2014.

WILLEMAN, Flávio de Araújo. Termo de Ajustamento de Gestão nas Concessões: Conversibilidade das Sanções Administrativas Pecuniárias em Investimentos. In: ROCHA, Fábio Amorin da (Coord.). Temas Relevantes no Direito de Energja Elétrica. Rio de Janeiro: Synergia, 2012. p. 809-823. 
WIND, Yoram. Models for Marketing planning and decision making. University of Pennsylvania: Whartin School, 1985.

ZANETI, Izabel Cristina Bruno Bacellar. Educação ambiental, resíduos sólidos urbanos e sustentabilidade. Um estudo de caso sobre o sistema de gestão de Porto Alegre, RS. Brasília: Universidade de Brasília, 2003. 